


\section{De Wend}

$p+5=16=2$

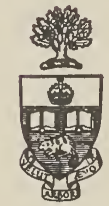

Library

of the

University of Toronto

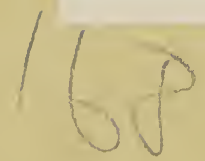


R.R Frema 
Wiltian... Hewtore De Wer

qunere hiv Shiend a Sear

- tlary Aliaco

- Volthanetore - Get blto 


\section{THE}

\section{HISTORY OF THE JEWS,}

FROM

\section{THE CHRISTIAN ERA}

\section{THE DAWN OF THE REFORMATION.}

\section{BY PHILIP HENRY GOSSE.}

PUELISHED ONDER THE DIREOTION OF THE COMMITTEE OF GENERAL IITERATURE AND EDUCATION, AFPOINTED BY TEE GOCIETY FOR PROMOTING CHRIGTIAN KNOWLEDGE.

\section{O N D O N :}

PRINTED FOR

THE SOCIETY FOR PROMOTING CHRISTIAN KNOWLEDGE;

SOLD AT THE DEPOSITORY,

GREAT QUEEN-STREET, LINCOLN'S INN-FIELDS, AND 4, ROXAL EXCHANGE :

AND BY ALL BOOKSELLERS.

1851. 
LONDON :

Printed by Samuel Bentley and Co., Bangor House, Shoe Lane. 


\section{CONTENTS.}

\section{INTRODUCTION.}

Peculiar interest attached to Israel.-Miraculous interposition.Prophecy.-God's object in choosing the nation.-Probation of man. - Israel's failure.-A postacy.-Atheism.-The Sadducees.-The Pharisees.-National arrogance.-Rejection of the Son of Man.Rejection of the Holy Spirit.-The Sceptre departed from Shiloh. - Roman governors.-Lawlessness of Priests and People.-False Christs.-Florus.

\section{THE REVOLT.}

Days of vengeance.-The outbreak.-Rivalry at Cæsarea.—Florus" villany.-Agrippa's mediation.-Capture of Masada.-The war and the peace party.-Song of Degrees.-Civil war.-King Menahem. -Ejection of the Romans from Jerusalem.-Perfidious massacre.Slaughter at Cæsarea.-Carnage in the Syrian cities.-Cestius' march.-Bethhoron.-Gibeon.-Historic associations.-Repulse of the Romans.-The capture of Bezetha.-Cestius' unexpected retirement.-Retreat of the Christians.-Slaughter and rout of the Roman army.-Jewish solng of praise.

\section{THE SIEGE OF JOTAPATA.}

The policy of Rome.-Preparations of the Jews.-Josephus.John of Gischala.-Defence of Galilee.-Ascalon.-Vespasian.Sepphoris. -Galilee ravaged.-Jotapata.-Its strength._Gadara.The Romans repulsed.-The siege.-Military engines,-Ingenious contrivances of attack and defence. - Scarcity of water.-The battering ram.-Exploit of Eleazar.-The breach.-The assault.-Boiling oil.--Repulse of the Romans.-Towers.-Jewish treachery.-The capture.-The massacre. 


\section{THE SUBJUGATION OF GALILEE.}

PAGE

Josephus' address and fortune.-Dreadful scene at Joppa.-The son of Shaphat.-Tiberias.-Taricheæ.-The Lake of Gennesaret.Sacred associations.-Massacre at Taricheæ.-Siege of Gamala.Vespasian's danger.- Mount Tabor.-Capture of Gamala.-Gischala.-Desolation of Galilee.-Its present state. 87. -118

\section{THE ZEALOTS.}

Arrival of John at Jerusalem.-Wickedness of the Zealots.-War in the streets.-The Idumeans.-Death of Ananus._Zacharias, son of Baruch.-Horrible condition of the city and country. ' 119-127

\section{THE RESPITE.}

Subjugation of Perea.-Fate of Bethanabris.-The Jordan.-Subjugation of Idumea.-Jericho.-Death of Nero.-Factions in Jerusalem.-John and Simon.-Entrance of Simon.-Vespasian made Emperor.

$128-136$

\section{THE LAST WINTER OF JERUSALEM.}

The final agonies. - Infatuation of the leaders.-The condition of the Temple.-Approach of Titus.-View of the city.-Imminent peril of the Roman general.-The encampment.-View from Scopus. -The Temple.-The walls.-The towers.-Hippicus.-Description of the Temple.-Fort Antonia.

$137-154$

\section{THE SIEGE.}

Attack on the tenth legion.-The Passover.-Fury of the factions.-Spoliation of gardens.-Mode of conducting a siege.-Catapults. - Ballistæ.-Panic in the host.-Besieging towers.-Terror of the inhabitants.-Breach in the wall.-The camp of the Assyrians. -The defence of the walls.-A second breach.-Street-fighting.The Romans repulsed.-Acra taken.-Splendour of the Roman line. -Pay-day.-Scarcity of provisions.-Wickedness of the city.Crucifixions. 


\section{THE SIEGE (continued).}

The Roman embankments.-Their destruction.-Three heroic Jews. -The rampart.-Famine.-Deserters.-Horrible cruelty.Progress of death.-A child eaten by its mother.-The embankments replaced.-Fall of the wall.-Capture of the Antonia.-Battle before the Temple.-The Romans repulsed.-Jewish valour.-End of the daily sacrifice.-Renewed assault on the Temple.-The Romans again repulsed.-Embankments against the Temple.-Destruction of the cloisters. - Successful stratagem.-Assault by fire.-Efforts of Titus to save the Temple.-The tenth of Ab.-Conflagration of the Holy House.-The magnificence of the sanctuary.-Desolation and desecration.-Zion.-A parley.-Destruction of Acra.-The Tyropæon.-Storming of the wall.-Timidity of the defenders.Massacre.

$175-200$

\section{THE DESOLATION.}

Titus' reflections.-Cruelty of the victors.-Extent of the destruction.-Days of vengeance.-Fearful sights and signs.-Prophets.Infatuation.-Demolition of the city and Temple.-Barbarity of Titus.-Fate of John and Simon.-The triumphal pageant.-The spoils of the Temple.-The arch of Titus.-A lamentation. 201-215

\section{REVOLTS UNDER TRAJAN AND ADRIAN.}

Subjugation of Machærus and Massada.-Odious tax.-Jealousy of Domitian.- Jude's grandsons.- Persecutions.- Nerva.- Trajan.-Revolt of the Jews.-Cyrene.-Terrific slaughter.-Cyprus.Mesopotamia.-Adrian's tyranny.-Rebuilding of Jerusalem as a heathen city.-Revolt of the Jews.-Bar-Cocheba.-Rabbi Akiba- Success of the Jewish leader.-Siege of Bither.-Fate of Akiba.Identification of the site of Bither.-Blindness of the Jews. 216-242

\section{THE TALMUD.}

Isolation of the Jewish people.-A period of rest.-Jewish bigotry against Christians.-The dispersion.-Eastern and Western Jews.-The Sanhedrim.-School of Tiberias.-Patriarch of the west.-Judah the Holy.-The Mishna.-The oral law.-The Gamara.-The Talmud.-Its puerility and blasphemy.-The Prince of the captivity.-Babylon.-The Prince's power and state. 


\section{CHRISTIANITY.}

PAGE

Jewish hostility to Christians.-Christian persecution of Jews.Jews' alliance with the Magi.-With the Arians.-Revolt at Sepphorus.-Julian the Apostate.-His favour to the Jews.-Project to rebuild the Temple.-Response of the Jews.-Miraculous suspension of the work.-Intolerance.-Theodosius.-The feast of Purim.Crucifixion of a child.-Opposite spirit of Hilary.-Neglect of the Hebrew language. - Extinction of the Patriarchate.

$969-282$

\section{THE GOTHIC DOMINION.}

Peace enjoyed by the Jews.-Theodoric.-Justinian.-A false Messiah.-Revolts. - Siege of Naples.-The Papacy.-Wise maxims of Gregory.-Conversions.-The slave-trade.-Its attractions to the Jew.-Decrees of councils on the subject.-Jews in Persia.A revolt.-Closing of the academies by Chosroes.--Alliance of the Hebrews with Chosroes II.-Sack of Jerusalem.-The spoils of the Temple.-Christian blood.-Heraclius enters Jerusalem.-Massacre of Jews.-Bigotry in Spain.-Intolerant edicts.

$290-311$

\section{A REVIVING IN THE BONDAGE.}

The rise of Mohammed.-State of Christendom.-The conquest of Arabia.-Of Mesopotamia.-Of Egypt. - Of North Africa.-Of Spain.-Of the East.-Siege of Jerusalem.-Capitulation.-Mosque of Omar.-Moderation of the Caliphs.-Moorish rule in Spain.Prosperity of the Jews.-Their golden age.-Favour of Charlemagne. -A Jewish ambassador.-Louis the Debonnaire.

$312-331$

\section{PERSECUTIONS.}

Persecution in the East.-The crusades.-Oppression of pilgrims. -Peter the Hermit.-His preaching.-Wandering armies.-Dreadful atrocities upon the Jews.-Siege and sack of Jerusalem.-The second crusade.-Persecutions in Germany-in France.-Popular antipathy.-Jews in England.-Egbricht.-William Rufus.-Horrible reports.-Coronation of Richard I.-Tumults.-Dreadful scene at York.-Confiscations and extortions.-Sale of Jews.-Sir Hugh of Lincoln.-Prohibition of usury.-Expulsion from England.-Cruelties.-Persecutions in France.-Banishments.-The shepherds.- 
Great massacres of Jews.-Expulsion from France.-Jewish prosperity in Castile.-Popular fanaticism.-Public disputations.-The Inquisition.-New Christians.-Expulsion from Spain.-Terrible sufferings.-Refuge in Portugal.-Cruel policy of Emanuel.-Tumult at Lisbon.-Jewish blood in the Peninsula.-Condition of the race in Italy.-Horrible outrages in Germany.-The Black Death.Massacres at Frankfort. - Strasburg. - Mentz. - Causes of these sufferings.-Religious Bigotry.-Conclusion.

\section{$24,127,242,289$ unilited and mutithed $4+58=$ LIST OF ILLUSTRATIONS.}

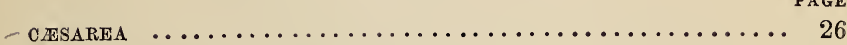

- MOUNTAINS NEAR THE DEAD SEA ................. 31

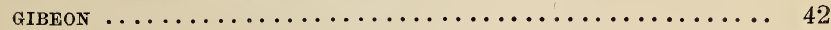

TERRACE CULTIVATION $\ldots \ldots \ldots \ldots \ldots \ldots \ldots \ldots \ldots \ldots \ldots \ldots \ldots \ldots$

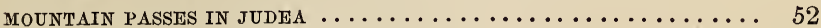

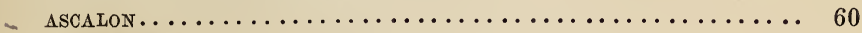

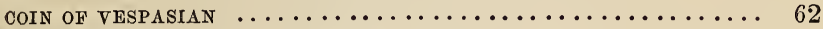

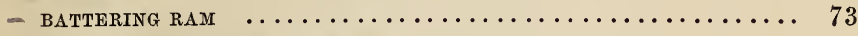

- TROOPS WITH LOCKED SHIELDS $\ldots \ldots \ldots \ldots \ldots \ldots \ldots \ldots \ldots \ldots$. 81

-

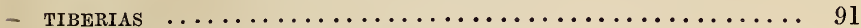

- THE JORDAN LEAVING THE LAKE $\ldots \ldots \ldots \ldots \ldots \ldots \ldots \ldots \ldots \ldots . \ldots . \ldots . \ldots$

- SEA of tIBERIAS ......................... 94

- SUMMit of MOUNT TABOR $\ldots \ldots \ldots \ldots \ldots \ldots \ldots \ldots \ldots \ldots \ldots \ldots \ldots$

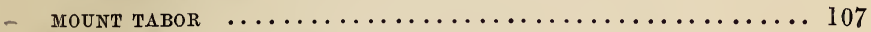

- RUINED Baths oN LAKE tiberias $\ldots \ldots \ldots \ldots \ldots \ldots \ldots \ldots \ldots \ldots$

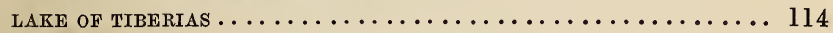

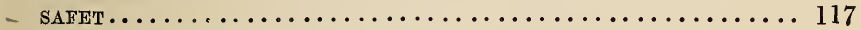

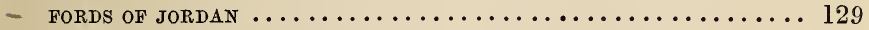

- THE JORDAN .......................... 130

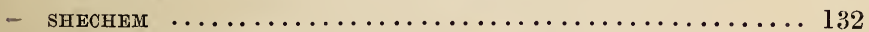

- PLAINS OF JERICHo $\ldots \ldots \ldots \ldots \ldots \ldots \ldots \ldots \ldots \ldots \ldots \ldots \ldots \ldots$

- JERICHO AND THE JORDAN...................... 134 
PAGE

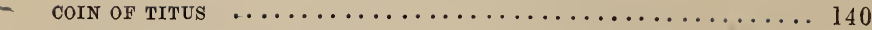

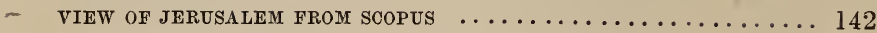

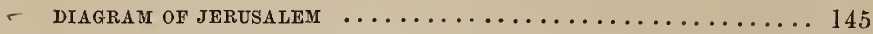

- WALLS OF MODERN JERUSALEM .................. 147

- TOWER HIPPICUS $\ldots \ldots \ldots \ldots \ldots \ldots \ldots \ldots \ldots \ldots \ldots \ldots \ldots \ldots$

- MOUNT MORIah ......................... 150

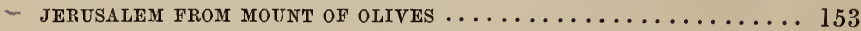

- MOUNT of OLIVES ......................... 156

- GaRden In JUdEA ........................ 158

- NORTH WALL .......................... 159

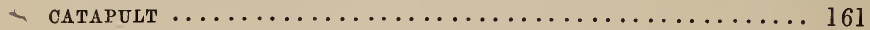

- ballista ............................ 162

- VALley of JehoshapHat ..................... 191

- POOL of siloaM.......................... 199

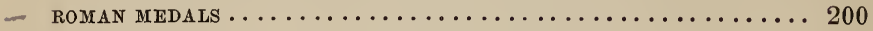

- MOUNT ZION ............................ 208

- SPOILS 0 THE TEMPLE $\ldots \ldots \ldots \ldots \ldots \ldots \ldots \ldots \ldots \ldots \ldots \ldots \ldots \ldots \ldots$

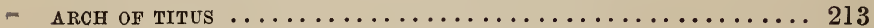

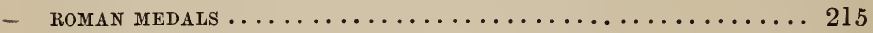

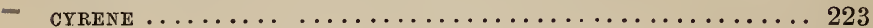

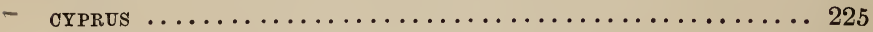

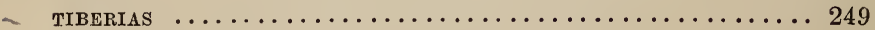

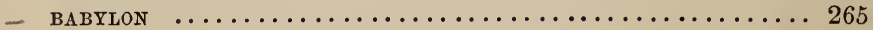

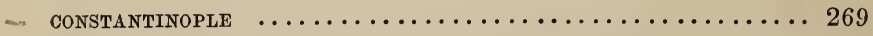

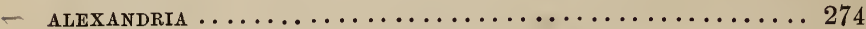

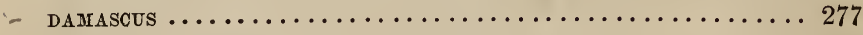

- MILAN CATHEDRAL ......................... 284

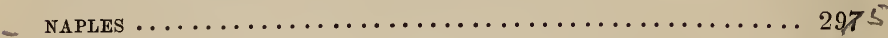

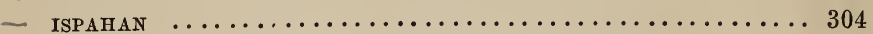

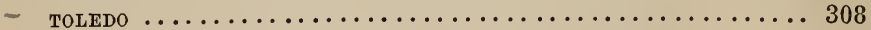

- STRAItS of GIRRALTAR ....................... 311

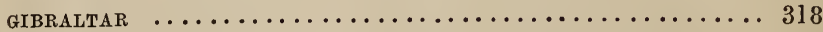

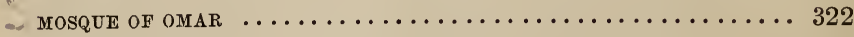

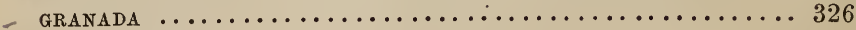

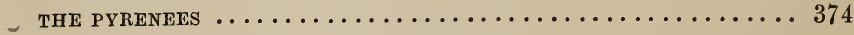




\section{T H E J E W}

\section{INTRODUCTION.}

THE people of Israel must ever be regarded with an interest unrivalled by that which attaches to any other of the nations of the earth. Where else shall we look for a people who can not only trace back their lineage with certainty to a single ancestor, but can point to historical records of their fortunes, detailing with indubitable truth, with inimitable pathos, and with minute particularity, their lights and shadows, their glories and their sorrows, during a period which stretches away into an antiquity of nearly four thousand years? And what picture of national history could ever display lights so bright, or shadows so deep and dark as this? No people ever stood on such a pinnacle of moral elevation, none ever fell into such an abyss of crime: no nation ever possessed such true grandeur, none ever groaned in such a depth of misery.

But there is one feature that strongly distinguishes the Jewish history, and throws it out in broad relief 
from every other. It is not so much the history of man's actions, as the history of God's dealings with man. Indeed, this might be truly said of all earthly transactions; that the hand of God is in them all, permitting, overruling, guiding, in His ever-watching Providence. "The Most High ruleth in the kingdom of men:- $\mathrm{He}$ doeth according to His will . . among the inhabitants of the earth." * But this general providential acting is not what we prominently see in the records of the Hebrew nation; but the direct and overt interference of Jehovah in person. The history of the seed of Abraham is a history of miracle; and that not in the way of rare and startling exception, but in its true and proper character: the absence of miracle was the deviation from the rule.

The nation was cradled in miracle. Their independent existence was effected amidst the most stupendous supernatural plagues upon their oppressors, and by mighty signs and wonders on their behalf. They marched through a divided sea; God himself descended in the darkness and thick cloud, "with the sound of a trumpet and the voice of words," to give them " the fiery law;" the cleft rock assuaged their thirst, and they fed upon the bread of heaven; while their forty years' wandering in the wilderness was guided by the pillar of cloud by day, and of fire by night. Jordan rolled back his waters to give them entrance into the promised land, and the sun arrested his course to help them to subdue it. But not to recal the numberless instances of Divine in-

* Dan. iv. 32,35 . 
terposition scattered through the Sacred Records, we will mention but these two permanent ones, the oracular responses by Urim and Thummim in the High Priest's breast-plate; and, above all, the constant indwelling of the Shechinah or visible Glory, first in the tabernacle, and then in the temple, until the Babylonish captivity.

It is true that in the latter periods of their history, this intermingling of the divine with the human was less marked than in the eras of their glory: their incorrigible rebellion and idolatry, more and more alienated their gracious King and God, and compelled Him to hide His face from them. Yet this was slowly done: the Glory of God lingered, as loath to depart from the Holy House ;* some of the darkest of their days witnessed glorious manifestations of Divine power, and that in an oppressor's land: even the guilt of princes and people afforded occasion for the exercise of a miraculous and extraordinary ministry; and the awful denunciations of inspired prophets were so many proofs of the omniscience, as well as of the long-suffering mercy of God. The solemn warnings, the affectionate remonstrances, and the tender appeals of these Divinely-inspired addresses, while they showed the deep-seated sin of Israel, most touchingly declared the grace of God, and His loving reluctance to break off His familiar communication with them. Nor was this light of prophecy a transient meteorglare; but was protracted through many centuries at least, and resembled the shining of the morning

* See Ezek. x. 4, 18, 19 ; xi. 23. 
star, which increases in brightness when the other stars are waning, and fades only at the approach of the rising sun. For it does not certainly appear that the gift of prophecy was entirely taken from the Jewish nation until the coming of the Lord himself, * when the mission of the servant merged into the superior mission of the Son.

Before we enter on that great tribulation, which is the proper subject of this volume, it will be needful briefly to glance at the eventful history of Israel, from the beginning; that we may discern the causes that produced, and the circumstances that led to their awful fall. Nor is the discovery of the former a thing difficult to be attained; if we search for it not by the light of philosophy, but by the light of the Word of God, and in an humble and teachable spirit.

Now will I sing to my well-beloved a song of my beloved touching his vineyard. My well-beloved hath a vineyard in a very fruitful hill : And he fenced it, and gathered out the stones thereof, and planted it with the choicest vine, and built a tower in the midst of it, and also made a wine-press therein : and he looked that it should bring forth grapes, and it brought forth wild grapes. And now, $\mathrm{O}$ inhabitants of Jerusalem, and men of Judah, judge, I pray you, betwixt me and my vineyard. What could have been done more to my vineyard that I have not done in it? wherefore, when I looked that it should bring forth grapes, brought it forth wild grapes? And now, go to ; I will tell you what I will do to my vineyard: I will take away the hedge thereof, and it shall be eaten up: and break down the wall thereof, and it shall be trodden down. And I will lay it waste : it shall not be pruned nor digged; but there shall come up briers and thorns: I will also command the clouds that they rain no rain upon it. For the vineyard of the LoRD of hosts is the house of Israel, and the men of Judah his pleasant plant : and he looked

* Luke i, 67 ; ii. $26-36$. 
for judgment, but behold oppression ; for righteousness, but behold a cry. Isa. v. $1-7$.

There was a certain householder, which planted a vineyard, and hedged it round about, and digged a wine-press in it, and built a tower, and let it out to husbandmen, and went into a far country: And when the time of the fruit drew near, he sent his servants to the husbandmen, that they might receive the fruits of it. And the husbandmen took his servants, and beat one, and killed another, and stoned another. Again, he sent other servants more than the first: and they did unto them likewise. But last of all he sent unto them his son, saying, They will reverence my son. But when the husbandmen saw the son, they said among themselves, This is the heir ; come, let us kill him, and let us seize on his inheritance. And they caught him, and cast him out of the vineyard, and slew him. When the Lord, therefore, of the vineyard cometh, what will he do unto those husbandmen? They say unto him, He will miserably destroy those wicked men, and will let out his vineyard unto other husbandmen, which shall render him the fruits in their seasons. Matt. xxii. $33-41$.

From these beautiful parables, and many similar passages in the Holy Scriptures, we learn what was one prominent object* in the purposes of God, in selecting one among the families of mankind, and separating it in so remarkable a manner from all others. It was the proving of man's obedience to God under the best possible circumstances. He had dealt with an apostate world in righteous judgment, "bringing in the flood upon the world of the ungodly ;" but this visitation, terrible as it was, had failed to produce any fruit in the reformation of man, and we soon find the post-diluvian world rising

* There were many other objects : such as the display of God's sovereignty in grace (Deut. vii. 7, 8); a testimony to the nations (Ezek. xx. 9 ); the preservation of true religion in the earth ; and in particular, the selection of a lineage through which the Messiah should come, and the announcement of His person and work in types and prophecies. 
up in haughty defiance of God, relapsing into gross idolatry, and practising the most abominable iniquity. The wisdom and mercy of God now adopts another mode of trial; instead of again sweeping off the guilty race as incorrigible, he passes by the bulk of mankind, leaving them to pursue their own course unchecked,* and selecting one man, enters into high and solemn covenant with him and with his posterity in him. Cradled in the severe school of Egyptian bondage, the seed of Abraham are at length brought out by a signal deliverance, their Almighty Saviour revealing himself to them as a friend in the destruction of their tyrants. Then bringing them into the solitude of the Arabian wilderness, He puts a mighty barrier between them and all other people, by condescending to become Himself their Legislator, Leader, and King, "hedging them round about" with a polity, a religion, and a law, most elaborate in its ordinances, moral and ceremonial, all eminently tending both to their wellbeing and to their national distinctness and isolation from all the families of mankind surrounding them. A land which was " the glory of all lands," had been given them by the covenant made with their great ancestor; and Jehovah engaged, by promise, to lead them to it, and put them into peaceable possession, subduing and rooting out before them the tribes who then held it, by His own Almighty power. Further, He covenanted to maintain them in this their inheritance, to bless it with an abounding fertility, to protect them from every enemy, and to 
crown them with all imaginable prosperity, and all this in perpetuity, - on condition of their holy obedience to the righteous and wholesome laws which $\mathrm{He}$ had set before them.

If ye walk in my statutes, and keep my commandments, and do them; then I will give you rain in due season, and the land shall yield her increase, and the trees of the field shall yield their fruit. And your threshing shall reach unto the vintage, and the vintage shall reach unto the sowing time: and ye shall eat your bread to the full, and dwell in your land safely. And I will give peace in the land, and ye shall lie down, and none shall make you afraid : and I will rid evil beasts out of the land, neither shall the sword go through your land. And ye shall chase your enemies, and they shall fall before you by the sword. And five of you shall chase an hundred, and an hundred of you shall put ten thousand to flight : and your enemies shall fall before you by the sword. For I will have respect unto you, and make you fruitful, and multiply you, and establish my covenant with your. And ye shall eat old store, and bring forth the old because of the new. And I will set my tabernacle among you: and my soul shall not abhor you. And I will walk among you, and will be your God, and ye shall be my people. Lev. xxvi. 3-12.

And it shall come to pass, if thou shalt hearken diligently unto the voice of the LoRD thy God, to observe and to do all his commandments which I command thee this day, that the LorD thy God will set thee on high above all nations of the earth. And all these blessings shall come on thee, and overtake thee, if thou shalt hearken unto the voice of the LorD thy God. Blessed shalt thou be in the city, and blessed shalt thou be in the field. Blessed shall be the fruit of thy body, and the fruit of thy ground, and the fruit of thy cattle, the increase of thy kine, and the fiocks of thy sheep. Blessed shall be thy basket and thy store. Blessed shalt thou be when thou comest in, and blessed shalt thou be when thou goest out. The LoRD shall cause thine enemies that rise up against thee to be smitten before thy face : they shall come out against thee one way, and flee before thee seven ways. The LorD shall command the blessing upon thee in thy storehouses, and in all that thou settest thine hand unto ; and he shall bless thee in the land which the Lord thy God giveth thee. The Lord shall establish thee an holy people unto himself, as he hath sworn unto thee, if thou shalt keep the commandments of the LorD thy God, 
and walk in his ways. And all people of the earth shall see that thou art called by the name of the LorD ; and they shall be afraid of thee. And the Lord shall make thee plenteous in goods, in the fruit of thy body, and in the fruit of thy cattle, and in the fruit of thy ground, in the land which the LORD sware unto thy fathers to give thee. The Lord shall open unto thee his good treasure, the heaven to give the rain unto thy land in his season, and to bless all the work of thine hand: and thou shalt lend unto many nations, and thou shalt not borrow. And the LorD shall make thee the head, and not the tail ; and thou shalt be above only, and thou shalt not be beneath; if that thou hearken unto the commandments of the LORD thy God, which I command thee this day, to observe and to do them. Deut. xxviii. 1-13.

Moreover, that nothing might be wanting to give a sanction to this solemn law and covenant, and that the utmost certainty might be secured to its promises and threatenings, the whole transaction was effected amidst the most awfully sublime and terrible manifestation of the Divine Presence in the sight of the whole people.

And it came to pass on the third day in the morning, that there were thunders and lightnings, and a thick cloud upon the mount, and the voice of the trumpet exceeding loud; so that all the people that was in the camp trembled. And Moses brought forth the people out of the camp to meet with God; and they stood at the nether part of the mount. And mount Sinai was altogether on a smoke, because the LoRD descended upon it in fire: and the smoke thereof ascended as the smoke of a furnace, and the whole mount quaked greatly. And when the voice of the trumpet sounded long, and waxed louder and louder, Moses spake, and God answered him by a voice. And the LorD came down upon mount Sinai, on the top of the mount : and the Lord called Moses up to the top of the mount; and Moses went up. And the Lord said unto Moses, Go down, charge the people, lest they break through unto the LoRD to gaze, and many of them perish. Exod. xx. 16-21.

And all the people saw the thunderings, and the lightnings, and the noise of the trumpet, and the mountain smoking: and when the people saw it, they removed, and stood afar off. And they said unto Moses, Speak thou with us, and we will hear; but let not God speak with us, 
lest we die. And Moses said unto the people, Fear not: for God is come to prove you, and that his fear may be before your faces, that ye sin not. And the people stood afar off, and Moses drew near unto the thick darkness, where God was. Exod. xxi. 18-2l.

Besides all this, Jehovah engaged to dwell among them, and to have a sanctuary in which $\mathrm{He}$ would take up His residence in the midst of them in a personal and visible manner.

Thus, then, did the trial of man proceed under the most favourable circumstances for eliciting his obedience; nor can we imagine any additional assistance which could have been afforded him, which would at the same time have left him the exercise of his free responsibility. The touching inquiry remains without an answer: "What could have been done more to my vineyard, that I have not done in it?"

And how did this highly-favoured people stand in the probation? Did they show that man, if opportunity presented and circumstances were propitious, could " of his own natural strength do good works pleasant and acceptable to God ?" and that there yet remained in him, notwithstanding the fall, a power and a will to render a faithful obedience? Alas! they utterly and miserably failed! All the wondrous exhibitions of grace and goodness with which they had been distinguished only brought out into sterner prominence that solemn truth, "There is none righteous, no, not one; there is none that understandeth; there is none that seeketh after God: they are all gone out of the way; they are together become unprofitable; there is none that doeth good, 
no, not one."* Even while Moses was yet on the mount receiving the details of the law from the mouth of God, and while "in the sight of the children of Israel the Glory of the Lord was like devouring fire on the top of the mount," they fell into the grossest idolatry, and made and worshipped a golden calf!

And this transaction was but a fair type and sample of their whole subsequent history. The covenant, indeed, was annulled thereby, as far as it had been made contingent on their obedience; and God might justly have given them over at once to the penalties of that law which they had despised and broken. But His thoughts are not as our thoughts; He brought them into the Promised Land, and through the slow lapse of fifteen centuries His longsuffering mercy protracted the trial, with the same undeviating result. "Their heart was not right with Him, neither were they stedfast in His covenant. But he, being full of compassion, forgave their iniquity, and destroyed them not: yea, many a time turned $\mathrm{He} \mathrm{His}$ anger away, and did not stir up all his wrath." $\psi$

To enter into an examination of this long period would be foreign to our purpose. It is, as we have said, a picture full of lights and shadows; the faithlessness and ingratitude of man is constantly contrasted with the mercy and goodness of God. Whenever national chastisements produced, though but in feeble measure and partial extent, a return to Him,

* Rom. iii. $10-12$.

+ Psalm lxxviii. 37, 38. 
they were exchanged for victory, peace and prosperity: He hastened to show that judgment was His strange work, and that He delighted in mercy. But affront after affront was put upon the majesty of Jehovah; His kingship was rejected; His ordinances were despised; His sabbaths were profaned; the foul rites of Baal, and the bloody worship of Moloch, were openly adopted as the religion of the majority; justice and judgment fled away; the land was defiled with blood; and abominable iniquities abounded. The defection of ten of the twelve tribes, to form a separate kingdom with a state idolatry, followed soon by their utter desolation and ruin by the Assyrians, who took them away into a captivity from which they never returned,-produced no permanent reformation or repentance in the remnant that was left, the tribes of Judah and Benjamin, that still adhered to the House of David. They waxed worse and worse; nor could the reign of one pious king, the zealous Josiah, prevail to do more than defer for a little while the evil day that was hastening on them also.

Moreover all the chief of the priests, and the people, transgressed very much, after all the abominations of the heathen ; and polluted the house of the Lord which he had hallowed in Jerusalem. And the Lord God of their fathers sent to them by his messengers, rising up betimes, and sending ; because he had compassion on his people, and on his dwelling place: But they mocked the messengers of God, and despised his words, and misused his prophets, until the wrath of the LoRD arose against his people, till there was no remedy. Therefore he brought upon them the King of the Chaldees, who slew their young men with the sword in the house of their sanctuary, and had no compassion upon young man or maiden, old man, or him that stooped for age: he gave them all into 
his hand. And all the vessels of the house of God, great and small, and the treasures of the house of the LorD, and the treasures of the king, and of his princes; all these he brought to Babylon. And they burnt the house of God, and brake down the wall of Jerusalem, and burnt all the palaces thereof with fire, and destroyed all the goodly vessels thereof. And them that had escaped from the sword carried he away to Babylon; where they were servants to him and his sons until the reign of the kingdom of Persia. 2 Chron. xxxvi. 14-20.

Thus was fulfilled a part of the evil threatened in that memorable exhibition of the blessings of obedience and the curses of disobedience, a portion of the promises of which we have already quoted.

The Lor shall bring thee and thy king which thou shalt set over thee, unto a nation which neither thou nor thy fathers have known; and there shalt thou serve other gods, wood and stone. Deut. xxviii. 36 .

But darker predictions of the same prophecy yet remained to be accomplished: severe as was the chastisement of the Babylonish captivity, it was light compared to what was behind: the cup of Judah's iniquity, as well as that of his misery, was not yet full. At the end of the predicted period of seventy years free permission and protection were afforded to the captives to return home, and rebuild their metropolis and temple. A comparatively small number, probably not exceeding 100,000 in all, availed themselves of the opportunity, and became the nucleus of the Jewish nation in its now dependent condition. For a few centuries longer, a precarious political existence was to be granted to them; but with the exception of a brief and solitary interval, during which the valour of the Maccabees wrested a fitful independence from the Seleucidan 
kings, - they sustained but the humble position of a provincial appendage to one or other of the great empires around them, tributary alternately to Persia, Macedonia, Egypt, Syria, and Rome.

The moral character of the nation, so far from being improved by the chastisements of God, evideutly proceeded from bad to worse. In one respect, indeed, there was an apparent change for the better; they never again fell into gross open idolatry; but the evidence of the Prophet Malachi suffices to show Jehovah's righteous estimate of their moral condition; a haughty contempt of His ordinances had grown up, and horrible crimes were prevalent among them; sorcery, adultery, false-swearing, oppression and murder, afford the dark hues with which the portraiture of that guilty age is dyed. And it is no small aggravation of its iniquity, that the priests, who should have been fountains of knowledge, and examples of holiness to the people, were eminently selfish and covetous, and took the foremost place in apostacy from God, and in atheistic hostility to him. And thus all were fast preparing the way for that "curse," which already darkly brooded over the nation, and with the threatening of which the canon of Jewish Scripture so ominously closes.

About this time two religious parties or sects sprang up, which gradually assuming more distinctness, at length came to embrace the great body of the people. The Sadducees, the freethinkers of their day, rejected the authority of the greater part of the Word of God, avowing a bold scepticism on 
those subjects which sense could not discern, or unassisted reason discover; denying, in particular, any futurity of either happiness or misery, reward or punishment. This infidelity, so palatable to the sensual and the luxurious, was adopted chiefly by the wealthy and high-born; while the doctrine and practice of the Pharisees carried captive the bulk of the common people. These affected the highest veneration for the law, insisting on a scrupulous observance of its minutest forms ; to which, indeed, they had added such a mountain of traditional rites and observances, for all of which they claimed an authority fully equal, if not superior, to that of the written Word, that their inculcations became an interminable succession of "heavy burdens, and grievous to be borne." But this religion was wholly a thing of outside show; the assumption of extreme sanctity was a cloak of all hypocrisy and iniquity: while they paid tithes upon mint, anise, and cummin, they had not the slightest regard to judgment, mercy or faith: they made long prayers in the public streets, but devoured the inheritance of the widow and the fatherless; they suborned witnesses to take away innocent blood, but had conscientious scruples about putting the price of it into the treasury; they made clean the outside of the cup and platter, but within they were full of extortion and excess; they were like whited sepulchres, which indeed appear beautiful outward, but are within full of dead men's bones, and of all uncleanness! Blind leaders of the blind! no marvel that both fell into the ditch ! 
Such was the once renowned Jewish nation; such the degenerate descendants of those to whom it was promised that the observance of their righteous statutes and judgments should be their wisdom and their understanding in the sight of the nations, and should elicit from them the admiring observation, "Surely this great nation is a wise and understanding people!"* A few, indeed, were "weeping in secret places" for the overflowings of ungodliness around them, and these were known to God, and precious in His sight; but their number was far too small and their influence too inconsiderable to throw any sensible light into the moral darkness that was thickening about them. $\psi$

With all this besotted ignorance of true righteousness, there existed the greatest pride and arrogance. They looked down on all other nations as dogs, unclean beasts, impure Gentiles; but had the greatest conceit of their own holiness. 'They boasted of the favour of God, and considered it as but their rightful due, on account of their descent from Abraham, and their observance of the law. "The temple of the Lord, the temple of the Lord, the temple of the Lord, are we," was their favourite boast ; but when He came, the Blessed One, who was the Lord of the temple, to whom the law with its priesthood and its sacrifices, its ordinances, festivals, and ceremonies,

* Deut. iv. 6.

+ We have not thought it needful to distinguish the Essenes. We know them only from Josephus's testimony, for they are never alluded to by the Lord or his apostles : they were probably few in number, and their peculiar tenets and practice appear to have been only an ascetic phase of Pharisaism. 
pointed, whom kings and prophets had spoken of and desired to see,- - they could discern " no form nor comeliness in Him, no beauty that they should desire Him."

The rejection of the meek and lowly Son of Man filled up the iniquity of Israel. "Full of grace and truth," He came unto His own, but His own received Him not: "full of grace and truth," the glorious Word made flesh, dwelt among them, but the proud, bitter, and worldly spirit that reigned in them, had no sympathy with Him. He went about doing good, healing their sicknesses and carrying their sorrows; but with the suicidal fury of a maniac, they trampled upon His love, and outraged His power, attributing both to the energy of Beelzebub. He would have healed the Daughter of Zion, but she would not be healed. "How often would He have gathered her children together, even as a hen gathereth her brood under her wings, but she would not!" And what remained, but that with weeping eyes and a bleeding heart, with a love that many waters could not quench, the rejected King and Lord should pronounce the ruin which $\mathrm{He}$ saw to be now inevitable?

And when he was come near, he beheld the city, and wept over it, saying, If thou hadst known, even thou, at least in this thy day, the things which belong unto thy peace! but now they are hid from thine eyes. For the days shall come upon thee, that thine enemies shall cast a trench about thee, and compass thee round, and keep thee in on every side, and shall lay thee even with the ground, and thy children within thee; and they shall not leave in thee one stone upon another; because thou knewest not the time of thy visitation. Luke xix. $41-44$. 
But even yet there was long-suffering with God: the door of mercy was not immediately closed. The sin was consummated; that guilty Deed, at which the sun shrank back aghast, and the course of nature was convulsed, the crime of crimes, was accomplished; man imbrued his hands in the blood of the Son of God, and killed the Prince of Life ! The doom was self-pronounced, "His blood be upon us, and upon our children!" but its execution yet lingered. A glorious exhibition was to be given of that truth, "Where sin abounded, grace did much more abound;" and the risen Jesus, sending forth his disciples upon their blessed errand of preaching repentance and remission of sins in His name, expressly commanded them to begin at Jerusalem! And well did they perform their work! Animated by the Holy Ghost, "with great power gave the apostles witness of the resurrection of the Lord Jesus;" and the burden of their testimony was this : "The God of our fathers raised up Jesus, whom ye slew and hanged on a tree. Him hath God exalted with His right hand, to be a Prince and a Saviour, for to give repentance to Israel, and forgiveness of sins." Amidst scorn, reproach, and blasphemy, in stripes and imprisonments, in stonings and deaths, in hunger and thirst, in cold and nakedness, did the disciples of the crucified and risen Lord pursue their untiring labour of love, preaching peace and forgiveness, through that precious Blood which Israel's guilty hands had shed. Nor was their mission without success; though they might complain that all day long they stretched 
out their hands unto a disobedient and gainsaying people, and though the national desolation could not be averted, yet a goodly " election of grace" was found; many myriads* of Jews believed the message of eternal life, and were gathered into the fold. But the nation with its rulers was incorrigible; their zeal for the law took the form of the bitterest hostility to, and persecution of, their Christian brethren; and the very last incident which the sacred Historian has recorded of Jerusalem is strikingly and mournfully characteristic of the moral corruption of the time. More than forty of the Jews, with the full concurrence of the chief priests and elders, bound themselves under a great curse, that they would neither eat nor drink till they had assassinated Paul! $\dagger$

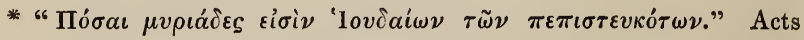
xxi. 20.

* In reviewing the moral and religious condition of the Jewish nation, we cannot help alluding to a mysterious and awful fact, abundantly noticed in the New Testament-the prevalence of demoniacal possession. The sceptical insinuation that this was nothing more than common lunacy or mental aberration, one who honours the inspiration of God's word feels to be scarcely worthy of his refutation. Various attributes of personality, as speech, fear, deprecation, request, individuality, number, and change of place, are ascribed to these indwelling demons, who are expressly called evil spirits and Satan ; above all, they recognised, and rendered in shuddering horror an involuntary homage to the Holy One of God, from whom they expected future torment at a time appointed. "Art thou come to torment us before the time?"

We do not at all moot the question, how far the fact of possession involved the moral obliquity of the individual possessed; nor would we inquire whether cases similar to these have ever occurred in other ages and nations ; the prevalence of the fact in the last days of Israel's nationality is the peculiarity that we notice. If the personal presence of 
Thus, if we bring the light of the blessed Word of God to bear upon the history of this people, we cannot fail to discover what was the cause of their deplorable overthrow. "Righteousness exalteth a nation, but sin is the reproach of any people;" and in Israel we behold the deepest sin, accompanied by the highest aggravations, that had ever yet been witnessed in this world. The corruptions of the heathens, vile as they were, could by no means be compared with the criminality of Israel; "the times of [their] ignorance God winked at;" but it is an established principle in His dealings with His creatures, and one which it behoves us to remember, that to whomsoever much is given, of the same shall much be required. "You only have I known of all the families of the earth; therefore I will punish you for all your iniquities." *

THE sceptre had not entirely departed from Judah, when SHILor came. Enfeebled it had long been; its light, with occasional flashings and brightenings, alternating with apparent extinctions, like the dying flame of a lamp, had been waning ever since the Babylonish captivity. With Herod the Great, the

God dwelling in manifestation in the midst of Israel was the chief glory of their palmy days, so, surely, the personal presence of Satan dwelling in manifested power and malignity in the same people, must be regarded as one of the most horrible traits of an age and a scene which is but too full of horrors. 
independence of Judea may be said to have expired; and though his son Archelaus "did reign in the room of his father Herod," he was no more than a puppet in the hand of Rome; and soon the shadow of his authority was taken away, and Judea became ostensibly a Roman province. Coponius, the first procurator, entered upon his government in the very year that the Lord Jesus, coming to the temple when twelve years old, may be said in some sense to have begun "His Father's business," and manifested himself to Israel.

The presence of a Roman governor, and Roman soldiers, with their idolatrous standards, and their haughty contempt of the Jewish "superstition," as well as the exaction of tribute and taxes, could not but deeply wound a people no less haughty than their masters. Collisions were frequent, as each party grew more and more intolerant of the other. Frequent insults to the temple-worship provoked the wild resistance of the populace, and these tumults were made the occasions of wide and indiscriminating slaughter. The brutal emperor Caligula blasphemously proclaimed himself a god, and issued orders for the erection of a colossal statue of him in the temple of Jerusalem. The Jews were in despair, and the prefect of Syria, to whom the execution of the imperial order was assigned, ventured with unwonted humanity to incur the heavy responsibility of writing to Caligula, deprecating his purpose. The emperor was furious ; but his timely death prevented the consummation of the blasphemy, and saved the considerate prefect. 
A rapid succession of vile governors, each almost more flagitious than his predecessor, brought the Jewish people to the verge of despair. Their rule, instead of being exercised for the well-being of the governed, had but one object,- - the enriching of themselves by all possible means. Early in the reign of Tiberius, Syria and Judea, worn out with their burdens, had prayed for a reduction of the taxes; "yet it was not the revenue that lay so heavy on the back, but the gratuities, confiscations, and plunder: the commander of troops could drive a whole town to contribution by a threat of billeting his men on the citizens : the unjust judge could condemn and execute one who refused a loan or gifts, or, if need were, a thousand; the aid of the police or military must be bought, and no public transaction could advance without a bribe at every step." *

The bonds of society were loosed; hosts of robbers infested the whole country, plundering with impunity; and bands of professed murderers abounded in the cities, whose trade was carried on either on their own account or for hire. "They slew men in the day-time, and in the midst of the city, chiefly at the festivals, when they mingled among the multitude, and, with daggers carried under their garments, slew their enemies. The first man so slain was Jonathan, the high-priest, after whose death many were slain every day, while the fear men were in of the like fate, was more afflict-

* Cockayne's " Civil Hist. of Jews," p. 240. 
ing than the calamity itself; and while everybody expected death every hour, as men do in war, so men were obliged to look before them, and to take notice of their enemies at a great distance; nor if their friends were coming to them, durst they trust them any longer; yet, in the midst of their suspicion and caution, they would be slain." *

The priesthood partook of the common lawlessness of the time. A quarrel arising between the chief-priests and the principal of the common people, each party assembled a multitude of partisans, carrying on a civil war in the streets of Jerusalem. The high-priests also would forcibly seize in the threshing-floors the tithes that were by right due to the inferior priests and I levites, many of whom, having no other support, were starved to death.

A remarkable sign of the times was the number of false Christs and impostors, who, preaching the unlawfulness of acknowledging the heathen dominion, gathered 'great multitudes after them, only to fall by the Roman sword. Some of these are noticed in the Acts of the Apostles; and their appearance had been long before predicted by the Lord, in conference with the unbelieving Jews, and in that memorable discourse with $\mathrm{His}$ disciples on the Mount of Olives, to which we shall have much occasion to refer. "I am come in my Father's name, and ye receive me not; if another shall come in his own name, him ye will receive. $\downarrow$ Many

* Josephus ; Wars, b. ii. c. xiii.

+ John v. 43. 
shall come in my name, saying, 'I am Christ,' and shall deceive many." *

The last and the vilest of the Roman procurators of Judea, was Gessius Florus, an execrable wretch. The rapacities of former governors, great and severe as they were, seemed like the deeds of honest men, when compared with the administration of this man. They had preserved some little regard to decency, by cloaking over their extortions; but he made an ostentation of his barbarities. "As though he had been sent to punish condemned malefactors, he omitted no sort of rapine or of vexation. He, indeed, thought it a petty offence to exact money from individuals; so he spoiled whole cities; and ruined entire corporations of men at once, and did almost publicly proclaim it all the country over, that they had liberty to turn robbers, provided only that he might go shares with them in the booty." Under such government whole districts and towns were brought to speedy desolation; the people abandoning their country in despair to flee into foreign lands.

Thus every aspect of public affairs presented omens of a terrible convulsion. Tyranny and license unchecked in the governors, exasperation and defiance in the governed; frightful crime pervading all; all the ties of social order loosened; every man hating and dreading his neighbour: sanguinary collisions between the people and the soldiery; all told but too surely of the approaching storm. The bolder 
and more turbulent spirits saw it coming, and hailed it with eager hope, as a deliverance from the hated yoke of the Gentiles: the timid and the helpless saw it too, and felt their hearts sink within them, as they anticipated its desolations; and we doubt not that a few were found, who, while justifying the fierce anger of the Most High God, could yet say, "O that my head were waters, and mine eyes a fountain of tears, that I might weep day and night for the daughter of my people!"

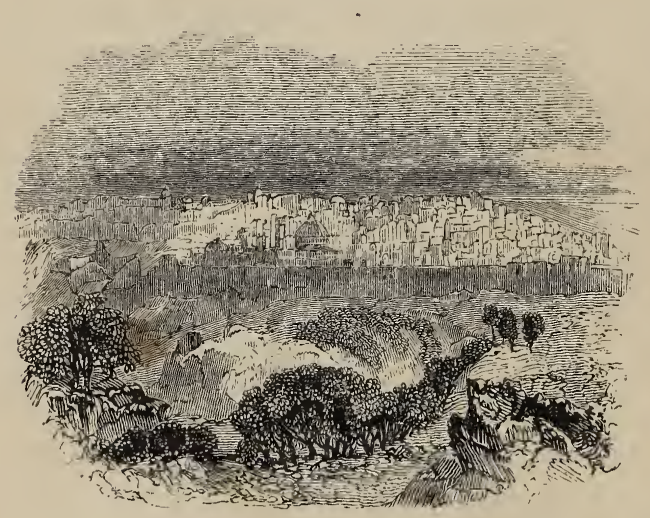




\section{CHAPTER I.}

THE REVOLT.

A.D. 66 .

Now were fast drawing on those "days of vengeance," when all things which were written must be fulfilled. The cruel oppressions of Florus, who seems to have been animated by a malice scarcely less than diabolical, were goading the Jews to madness. The presence of Cestius Gallus at Jerusalem at the Passover, enabled the assembled people, to the number of three millions, to appeal to him as the prefect of Syria, against the tyrant. But Cestius was a kindred spirit, and gave them no redress ; and Florus pursued his tyranny unchecked, omitting no opportunity to provoke the unhappy populace to revolt, that he might seize their treasures, without any fear of their accusing him to Cæsar.

It was in Cæsarea that the long smouldering fire first burst out into a flame. Though a century had not elapsed since its foundation, it had already grown up to a large and populous city, eminent for wealth and magnificence. The two races who inhabited it, the Jews and the Syro-Greeks, continually contended for superiority. They were pretty equally balanced; the Jews were the more wealthy and 
numerous, but the Greeks had the sympathy of the Roman soldiery, who were mostly levied from the province. Feuds and tumults increased in frequency and virulence; and the princely streets often ran with the blood of the citizens. An appeal to the emperor, on the recal of Felix, had resulted in the

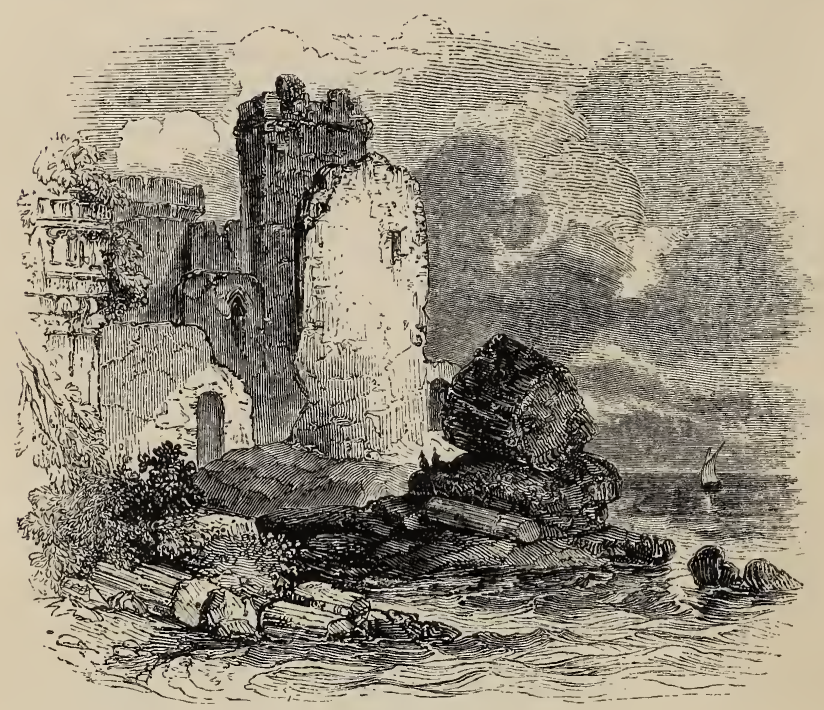

CESAREA.

pre-eminence being assigned to the Greeks, and the humiliation of the Jews. This decree, obtained by bribery, did not heal the breach; and the Greeks grew daily more insolent, the Jews more desperate and revengeful.

About this time a Greek, who owned the land on which the Jewish synagogue was built, wantonly began to erect workshops and other buildings against 
it, to annoy the worshippers. Certain leading men of the Jews, having no other resource, offered Florus a gratuity of eight talents, (3600l. sterling,) on condition of his interference. He received the bribe, and immediately removed to a distance, leaving the disputants to settle the matter as they thought proper. A coarse insult offered to the Jews on the following Sabbath brought on a battle, in which they were beaten: they then retired from the city with their sacred books. A deputation, sent to complain to Florus, delicately hinted the obligation of the eight talents; on which the shameless villain threw them into prison.

Intelligence of this infamous transaction deeply stirred the city of Jerusalem; but the governor, bent on driving the wretched people to rebellion, seized the occasion of their indignation to demand seventeen talents (7650l.) from the temple-treasury, on the pretence of the emperor's necessities. The city was in an uproar; the people ran about with outcries, some calling wildly upon Cæsar for help against Florus, while others, in bitter sarcasm, ran about with a basket loudly soliciting alms "for the poor beggar." Secretly gratified at the opportunity which the sedition afforded, he instantly led his whole force upon the city. The irritation, however, had subsided; and the poor oppressed people hoped by a submissive bearing, and by a friendly salutation of the army, to disarm the tyrant's resentment. Vain hope! Having let loose his brutal soldiers upon a portion of the city, called the Upper Market, with license for plunder and massacre, three thou- 
sand six hundred persons, including women and innocent babes, were slain on that day: many of these were scourged and crucified.

This tragical event, the sad prelude of bloodier days to come, which must be considered as the actual commencement of the Jewish war, happened on the 16th day of the month Jyar, answering to April or May, in the year 66 of the Christian era.

On the following day the most pathetic lamentations for the dead were mingled with imprecations upon Florus, from the agonized multitude assembling on the scene of the massacre. But the elders, with the chief-priests, dreading worse evil, besought the populace to refrain from provoking one who had the power to do them further injury: and they quietly dispersed. The wicked governor's appetite for blood and plunder was, however, but whetted, not slaked, by the tragedy of the preceding day; and with fatal subtilty, he laid another snare for the poor doomed sons of Israel. Two cohorts from Cæsarea were advancing towards Jerusalem, and the people were commanded to go out of the city, and meet them with congratulations and shouts of welcome. It was a hard task; but the entreaties and persuasions of the priests succeeded in repressing the natural aversion of the people to so degrading an humiliation; and so, quietly and meekly, the injured Jews, with their white-robed priests at their head, marched out to salute the approaching soldiers, little dreaming of the cruel snare that had been set for their feet. For Florus had sent secret orders to the soldiers to meet their advances with contemptuous silence; and if 
this insult should provoke them to any expression of disapprobation, to fall upon them without mercy.

All fell out as the plotter of so vile a scheme could have wished. Some of the fiery Jewish youth, stung by the cool contempt of the soldiery, broke out into audible murmurs against the oppressor. The troops instantly turned upon them, and struck them down with their staves; and as they fled, the cavalry dashed among them, trampling down the unresisting crowd with savage barbarity. Unarmed and unprepared for war, the defenceless multitude thronged back into the city, but the tardy passage of the citygate ill-suited the eagerness of the flying hosts, and great numbers were suffocated and crushed to death, both there and in the narrow streets: the savage army all the while availing themselves of the panic to increase the slaughter. Through the suburb of Bezetha the living stream poured along, pursuers and pursued; till it became evident that the object of the former was to push on and obtain possession at the same time of the glorious Temple, and the strong fortress of Antonia. To aid them in this attempt Florus himself made a sally from the $\mathrm{Pa}$ lace, but by this time the city was in arms. The people crowded into the streets, blocking up the way of his troops, while others mounting upon the tops of their houses, cast down upon them showers of stones and darts. Thus baffled, the governor retreated to the palace.

The object of the desired possession of the Antonia being evidently the easy access to the Temple, to which the fort was attached, the people got 
upon the cloisters or porticoes which connected them, and by destroying these, cut off the communication. All hope of securing the sacred treasure by this means being destroyed, Florus retired from the city, leaving only one cohort as a garrison.

Accounts of these transactions were sent to the prefect, Cestius, by both parties, coloured, we may well suppose, according to the views and prejudices of each; the petition of the Jews, however, was supported by the intercession of Bernice, the patriotic sister of King Agrippa. The Roman sent one of his tribunes to examine the affair on the spot, who meeting on his way with Agrippa, they entered the city together. The peaceful and respectful demeanour of the Jews satisfied the tribune that their exasperation was not against the Roman dominion but against Florus, and having exhorted the people to maintain their loyalty, he offered up his devotions in the outer court of the Temple, as a Gentile might lawfully do, and returned to Cestius. But the keen discernment of Agrippa saw that disaffection deep and strong existed; and, therefore, calling the multitude together, he addressed them in an admirable specimen of argumentative oratory, filled with the most cogent appeals to their hopes, fears, and affections, beseeching them even with tears not to bring the desolations of war upon their families, their country, their beautiful city, and the Holy House. For awhile his efforts seemed crowned with success : moved by the tears of the king and his sister, the people began to rebuild the cloisters, and to collect the deficient tribute; but, in an evil 
hour Agrippa passed the precarious limits of popular tolerance by advising them to submit again to the hateful Florus. The abhorred name roused up the sleeping passions of the populace to fury; and with insane blindness the multitude turned against their kind and powerful friend, driving him out of the city, with insulting language, and at length even with stones. In sorrow and anger, not unreasonable at such a return for his kindnesses, the king retired into his own kingdom of Chalcis, leaving the proud city to its irremediable doom.

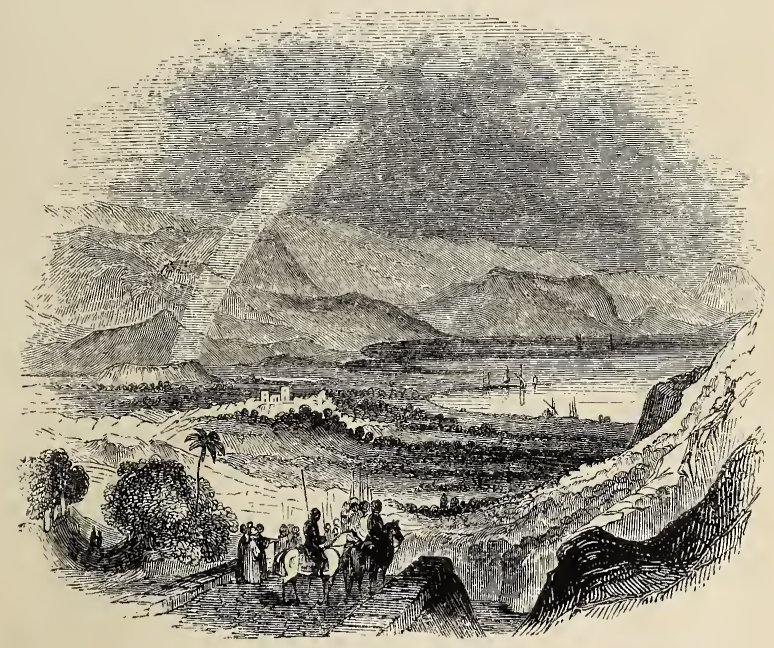

MOUNTAINS NEAR THE DEAD SEA.

As yet, however, the breach was not irreparable; the Jews had, indeed, drawn the sword, but they had not yet thrown away the scabbard. But about the time of the departure of Agrippa some of the more 
impatient and fiery spirits proceeded to extremities, which Rome could not forgive. On the summit of a precipitous hill near the Dead Sea stood the small but strong and important fortress of $\mathrm{Ma}$ sada, originally built by Jonathan the Maccabee, and greatly strengthened by Herod the Great. Into this stronghold a party of Jewish warriors obtained admission by stratagem, and put the Roman garrison to the sword. At the same time the leaders of the war-party in the metropolis hurled defiance at Rome, by refusing any longer to sacrifice for the emperor, or to receive any more his customary offerings to the Temple. This was chiefly owing to the advice of Eleazar, the son of the highpriest, and himself the governor of the 'Temple, a young man more intrepid in action than wise in counsel. The pacific part of the inhabitants foresaw with alarm the consequences of this determination; and spared no efforts to prove that the practice of antiquity, as well as the law itself, had permitted the sacrificial intercession for foreigners, and had freely received their votive offerings. And, indeed, they had reason and truth on their side; for the very existence of the Court of the Gentiles was a silent witness of such admission; while the dedicatory prayer of their great King, who had built the first Temple, distinctly avowed it.

Moreover concerning the stranger, which is not of thy people Israel, but is come from a far country for thy great name's sake, and thy mighty hand, and thy stretched out arm; if they come and pray in this house; then hear thou from the heavens, even from thy dwelling place, and do according to all that the stranger calleth to thee for ; that all people of the earth may know thy name, and fear thee, as doth thy people Israel, and 
may know that this house which I have built is called by thy name. 2 Chron. vi. $32,33$.

It is not to be supposed, that the Roman emperors, idolatrous heathens as they were, understood or appreciated the worship of Jehovah. With them the mention of the imperial name in the public sacrifices and liturgies would be regarded as merely a state compliment; and the presentation of offerings to Him whom they would suppose one of the common herd of divinities, one of "the gods many, and lords many," to whom the fertile fancy of man had attributed local patronage,-as a piece of state policy. Nor can we imagine that the turbulent priesthood of the degenerate Hebrew nation was actuated by any zeal for the holiness of Jehovah in denying to the unclean Gentile a part in His worship: the one party would receive it, as the other fully intended it, as a public affront to Rome, and a renunciation of its allegiance. And so perfectly was this understood at Jerusalem, that even while the pacific were arguing the legality of the acts now forbidden, their opponents, impatient of the argument, forsook the Temple and its service to prepare for war.

In all times of public commotion the people will be found to separate themselves into two parties: the one eager to push forward the contemplated changes, the other willing to maintain existing conditions. Hope is most prominent in the one, fear in the other. In the former party the young, the bold, the excitable, the dissolute, the needy,- those who have little to lose, everything to gain by change 
-take their eager place: to the latter shrink the old, the timid, the sedate, the wealthy, who have everything to lose, with no prospect of gain. Each party misunderstands the other, condemns it as selfish and destitute of patriotism, and exalts its own principles.

The leaders of the considerate party saw that all was well nigh lost, and, as a last resource, sent an embassy to Florus, and another to Agrippa, beseeching them to come at once with an overwhelming force, and cut off the sedition in the germ before it should spread and involve the whole province in common ruin. Right glad was Florus to hear how well his satanic plots were working: from his retirement he watched with grim delight his prey taken in the toils, and would not lift a finger to prevent a consummation which he so heartily desired. On the other hand, the candid and nobleminded Agrippa, a firm believer of the prophets, * and therefore a true friend to Israel, forgetting the affront so lately put upon him, and earnestly desirous to preserve the city and the Temple, dispatched without delay three thousand cavalry, with the master of his horse, and the general of his army, to maintain, if still possible, the peace of Jerusalem.

But peace unhappy Jerusalem was to know no more: forgetful of her ancient name, $\downarrow$ when he who was both King of Righteousness and King of Peace ruled over her, she had rejected the Prince of Peace, and now the olive-bearing dove had left her for long

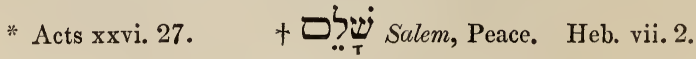


long ages; not even yet passed away. And yet we know there was even then a goodly band of gentle ones, the true lovers of peace, within her devoted walls, who could with true hearts, while with boding fears, sing, as their fathers had done, the beautiful

\section{SONG OF DEGREES.}

I was glad when they said unto me, Let us go into the house of the LORD.

Our feet shall stand within thy gates, O Jerusalem.

Jerusalem is builded as a city that is compact together:

Whither the tribes go up, the tribes of the LorD, unto the testimony of Israel, to give thanks unto the name of the LoRD.

For there are set thrones of judgment, the thrones of the house of David.

Pray for the peace of Jerusalem: they shall prosper that love thee.

Peace be within thy walls, and prosperity within thy palaces.

For my brethren and companions' sakes, I will now say, Peace be within thee.

Because of the house of the LorD our God I will seek thy good.Psalm cxxii.

It is sad to turn from these gentle breathings to the grim realities enacting in the streets of unhappy Salem. Civil war now raged : the principal inhabitants, with the high-priest, encouraged by the addition of Agrippa's reinforcement, seized on the upper city, Zion, while the insurgents, under Eleazar, took possession of the lower city and the Temple. Each party strove to dislodge the other, mutually contending with sling-stones and javelins. For seven days the conflict was maintained in the streets, with perpetual slaughter, but without any decisive superiority: at length a great number of the assassins from the lower city and suburbs joining the insurgents, the increase of strength and daring was presently 
manifested. Assembling in great force, they made a vigorous assault upon the upper city, which they at length carried; the royal troops fled, and the victorious party with suicidal hands set fire to the house of the high-priest, the palaces of Agrippa and Bernice, and the office of the public archives. This last was burned to gain the countenance of that large portion of the needy population, who were in debt; for in this place were kept the creditors' bonds, with other records. The principal men of the vanquished concealed themselves in cellars and vaults, while others, including the high-priest, and many of the troops, fled to the upper palace, within the strong gates of which they might still defy their enemies; the latter, contented with their conquest, or wearied with bloodshed, at length retired to their own quarters.

The strong fortress Antonia was garrisoned by the single cohort left by Florus ; the feebleness of which emboldened the insurgents to besiege it, which they did with such success, that in two days they effected an entrance, slew the soldiers, and set fire to the citadel. This important conquest occurred on the 16 th of $\mathrm{Ab}$ (answering probably* to the beginning of August). They immediately marched on the upper palace, where the remnant of Agrippa's army had entrenched themselves, and, dividing themselves into four companies, attempted to take it by assault; being, however, repulsed by the archers from the

* The days of the Jewish months in Josephus cannot be fixed with exactness to those of our computation. See Prideaux"s "Connection." Pref. to vol. i. 
battlements, they contented themselves with a strict blockade.

While things were in this condition there suddenly appeared before the walls of Jerusalem a new adventurer. Judas of Galilee, who "in the days of the taxing had drawn away much people after him," had been slain long before with two of his sons; but his doctrine, that the Hebrew people should be subject to none but God, had become increasingly popular. One son yet survived, whose name of Menahem would recal the memory of a vigorous but cruel Israelitish king, himself a successful insurgent. This man gathered around him a band of desperate men at Masada, broke open the splendid arinoury of Herod, and thus accoutred his body-guard, whom he led to Jerusalem. The insurgents threw open the gates with rapture, and King Menahem, for he had assumed the royal state and title, took the command of the city by acclamation. He ordered the siege of the Palace to be pressed with vigour, but the want of machines and implements of assault, and the showers of missiles from above, still delayed the capture. By means of a mine, however, the assailants fired a tower and overthrew it; and this led to a capitulation, by which the Jews and Agrippa's men were permitted to retire ; but as no terms were allowed to the few Romans, they were compelled to flee for safety to the strong tower built by Herod on the wall that overlooked the Tyropœon.*

But the popularity of Menahem was short-lived. The sanguinary tyranny which he began to practise

$$
\text { * Cheesemongers' Valley. }
$$


turned the hearts of his new subjects against him; and Eleazar, who could ill brook the loss of the authority which he had hitherto wielded, artfully inflamed their resentments. They fell upon him as he was worshipping with royal pomp in the 'Temple; and, though he found a momentary refuge in an obscure part of the city, the populace dragged him forth, and slew him with great barbarity, with most of his subordinate chiefs.

The death of Menahem did not prevent or slacken the prosecution of the siege. The handful of Roman soldiers imprisoned in the towers saw that resistance was hopeless, and agreed to surrender. The conditions, confirmed by solemn oath on the part of the Jews; were, that the lives of the garrison should be spared, but that they should deliver up their arms. On the faith of the treaty the Romans marched out; no affront was offered till they had laid down their arms; but as soon as this was completed, the Jewish multitude fell upon them with an indiscriminate slaughter. They attempted no resistance, nor asked for mercy, but reproached the perfidy of their murderers. They were slain to a man, with the exception of the general Metilius, who agreed to submit to circumcision, and was spared. As if to enhance the wickedness of this horrible deed, it was perpetrated on the Sabbathday.

By an awfully retributive coincidence, on the very day that this tragedy was perpetrated at Jerusalem, one equally bloody was enacted at Cæsarea; where the Greeks, suddenly rising, slew in one hour 
above twenty thousand of the Jewish inhabitants, completely extirpating the devoted race from that city; for the few that fled were waylaid by the wicked Florus, and sent to the galleys. This dreadful massacre roused the whole nation; and henceforward slaughter to the uttermost of their power was the object of each hostile party, and was executed wherever they met. The Jews felt that every man's hand was against them, and turned their hand against every man. In revenge for the barbarities at Cæsarea, they fell without mercy upon the Syrian cities, Philadelphia, Sebonitis, Gerasa, Pella, Scythopolis, Gadara, and Hippos, which they laid waste; burned some cities of Gaulonitis; attacked the Tyrian city Kedasa, Ptolemais, Gaba, and even Cæsarea itself; Sebaste (or Samaria), and Ashkelon they burned to the ground; Anthedon and Gaza suffered a like fate. The demolition, more or less complete, of these cities, with the devastation of the surrounding hamlets, was accompanied with tremendous slaughter.

Nor were the Syrians idle or passive : every city was inhabited largely by Jews, and these, as well in self-defence as in revenge, were massacred. Every city presented the appearance of two hostile camps, in which the security of one lay in the utter destruction of the other. Horror, fear, exasperation, and thirst for blood, inflamed more and more by its gratification, filled the whole province. The burning ulcer soon spread: more distant cities where Jews were found (for they were at this time widely scattered) partook of the raging madness: in 
Alexandria, the second city of the empire, not fewer than fifty thousand Jews perished in one dreadful tumult.

As Judea was now at open war with Rome, the prefect of Syria, Cestius Gallus, who had the military command of the province, could no longer remain inactive. Indeed it is a proof of his incapacity, that he allowed the revolt to attain such a head before he attempted to quell it; unless, like the base and implacable Florus, he too desired to see the nation irrevocably committed to a hostile policy to Rome. At length, however, he set out from Antioch, at the head of about twenty-three thousand troops, partly Romans, and partly auxiliaries; the latter supplied by King Agrippa, Antiochus, and the tetrarch Sohemus, of whom the first and the last accompanied the prefect on his march. The troops were divided nearly as follows:

Romans.

Horse. Foot.

The twelfth legion . . . . - _ 4200

Selected men . . . . . - $\quad 2000$

Six cohorts . . . . . - $\quad 2500$

Four troops . . . . . . $1200 \quad-$

Allies.

From Antiochus $\quad$. $\quad$. $\quad$. 20003000

From Agrippa . . . . . $2000 \quad 2000$

Under Sohemus . . . . $\quad \begin{array}{lll} & 1300 & 2700\end{array}$

$$
\text { Total . . } \overline{6500} \overline{16,400}
$$

This army was swelled on its march by the accession of irregular bodies of volunteers out of the Syrian cities, whose hatred to the Jews, and desire for plunder, stood in the place of skill and discipline. 
Zebulon, a strong city on the southern border of Galilee, was the first to meet the Roman general's vengeance : the inhabitants had fled on his approach to the neighbouring mountains, but abundance of plunder was left to the rapacity of the soldiery. Its numerous public edifices, which were built in a style of unusual magnificence, were burned to the ground. But the watchful Jews, observing that the greediness of the Syrians for pillage had induced them to linger behind the army, seized the opportunity of rising upon them, and cut them off to the number of two thousand.

Cestius continued his onward march to Cæsarea; whence he sent a portion of his army to the seaport town of Joppa, and another detachment to the province of Galilee. Both parties were successful, accomplishing their missions with fire and sword; while a third troop ravaged the neighbourhood of Cæsarea with unsparing ferocity. Thence again the stern Roman pursued his way; Antipatris and Lydda offered no resistance to his onward march, for the males were all assembled at Jerusalem to keep the Feast of Tabernacles, which took place about the beginning of October.

Ascending the long and winding pass of Bethhoron, where the rough rock had been anciently cut into steps to facilitate the ascent, the army at length pitched their camp at Gibeon, within sight of the "mountains" that were "round about Jerüsalem." And here from his craggy eminence the Roman Eagle looked down upon the quarry at his feet, bleeding at every pore from self-inflicted wounds, 
and, anticipating an easy prey, already gloated in the death-struggles of his victim.

The spot on which the Roman army lay encamped was one of singularly romantic beauty. The town . of Gibeon was situated about five miles north by west from Jerusalem, on the summit of a single oblong hill, which rose abruptly, with steep precipitous sides, from the bosom of a large plain or basin, surrounded on the west and south by mountains.

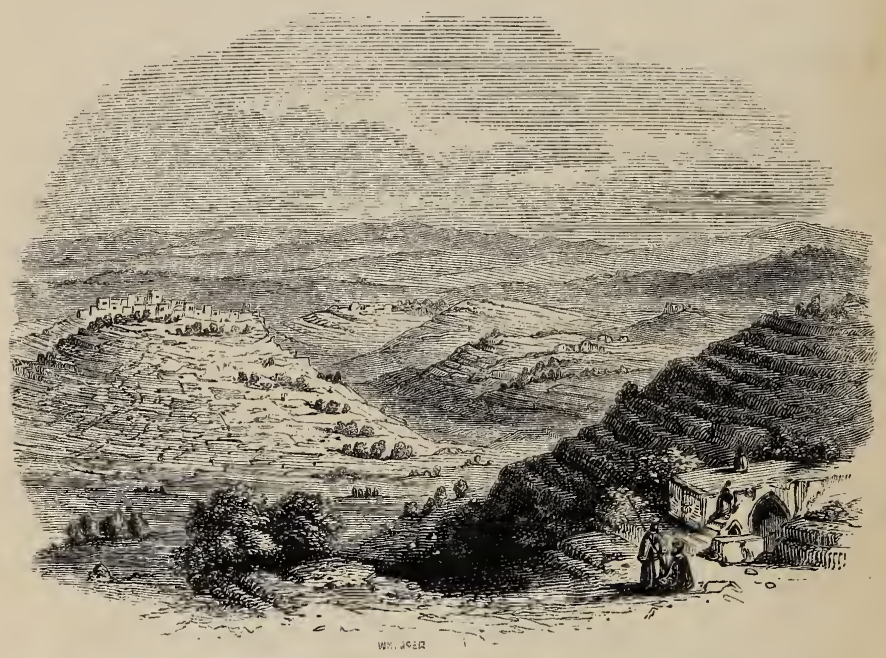

GIBEON.

The smiling plains at the foot of this rocky eminence were of "more than common fertility, as they are to this day, spread over with waving corn-fields, and orchards of pistachios, figs, and pomegranates, and groves of the graceful olive. The terraced sides 
of the hills were covered with trailing vines of great luxuriance, from which the purple clusters had just been gathered; for Israel was keeping (sadly, indeed!) the Feast of Ingathering. Behind, a little to the north of the setting sun, was the pass of Bethhoron, winding along the extremity of a sort of promontory, that jutted out between two deep valleys issuing from the mountain.

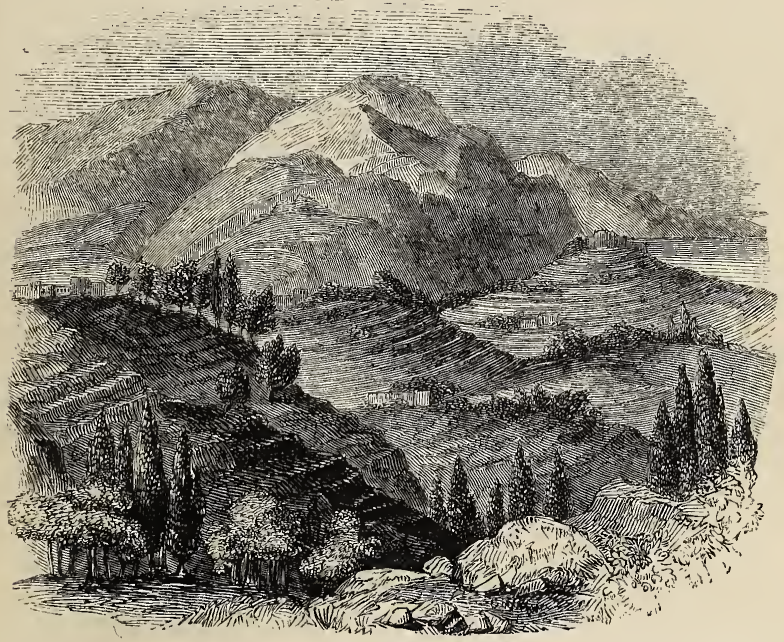

TERRACE CULTIVATION.

But this was not only a scene of wild and picturesque beauty, it was also a scene of ancient renown. For here it was that the signal victory was obtained over the confederate Amorite kings, when Joshua led Israel's forefathers into the goodly land. And it was on yonder ascent that the invincible 
captain stood, when, looking back and seeing the sun's last ray about to leave the summit of Gibeon, he in mighty faith arrested the descending orb of day, and completed the destruction of his enemies. But let us read the record from God's own Word of inspiration.

Now it came to pass, when Adoni-zedec King of Jerusalem had heard how Joshua had taken Ai, and had utterly destroyed it; as he had done to Jericho and her king, so he had done to Ai and her king; and how the inhabitants of Gibeon had made peace with Israel, and were among them ; that they feared greatly, because Gibeon was a great city, as one of the royal cities, and because it was greater than $\mathrm{A}$, and all the men thereof were mighty. Wherefore Adoni-zedec King of Jerusalem sent unto Hoham King of Hebron, and unto Piram King of Jarmuth, and unto Japhia King of Lachish, and unto Debir King of Eglon, saying, Come up unto me, and help me, that we may smite Gibeon : for it hath made peace with Joshua and with the children of Israel. Therefore the five kings of the Amorites, the King of Jerusalem, the King of Hebron, the King of Jarmuth, the King of Lachish, the King of Eglon, gathered themselves together, and went up, they and all their hosts, and encamped before Gibeon, and made war against it. And the men of Gibeon sent unto Joshua to the camp at Gilgal, saying, Slack not thy hand from thy servants ; come up to us quickly, and save us, and help us : for all the kings of the Amorites that dwell in the mountains are gathered together against us. So Joshua ascended from Gilgal, he, and all the people of war with him, and all the mighty men of valour. And the Lord said unto Joshua, Fear them not; for I have delivered them into thine hand: there shall not a man of them stand before thee. Joshua therefore came unto them suddenly, and went up from Gilgal all night. And the Lord discomfited them before Israel, and slew them with a great slaughter at Gibeon, and chased them along the way that goeth up to Beth-horon, and smote them to Azekah, and unto Makkedah. And it came to pass, as they fled from before Israel, and were in the going down to Beth-horon, that the LorD cast down great stones from heaven upon them unto Azekah, and they died : they were more which died with hailstones than they whom the children of Israel slew with the sword. Then spake Joshua to the LorD in the day when the Lord delivered up the Amorites before the children of Israel, and he said in the sight of Israel, Sun, stand thou still upon 
Gibeon; and thou, Moon, in the valley of Ajalon. And the sun stood still, and the moon stayed, until the people had avenged themselves upon their enemies. Is not this written in the book of Jasher? So the sun stood still in the midst of heaven, and hasted not to go down about a whole day. And there was no day like that before it or after it, that the LoRD hearkened unto the voice of a man: for the LoRD fought for Israel. Josh. x. 1-14.

Whether it was that these memories of the glorious past came thronging upon the inhabitants of Jerusalem, when they heard that the Roman was at Gibeon, or whether their mournful minds were intent upon the gloomy present,- they seized their arms, and though it was the Sabbath day, (probably " the last day, that great day of the feast,") poured out by countless thousands from the gates, and fell with irresistible fury upon the hostile camp. Horse and man gave way before that living tide; onward it rushed right through the host; and but for the timely charge of a troop of light cavalry, who had wheeled round to the rear, a good account had Israel that day rendered of his proud foes. As it was, upwards of five hundred Romans were slain in this encounter, while the Jews effected their return to the city with a loss of only twenty-two men; but the valiant Simon, the son of Gioras, a leader of whom we shall hear much hereafter, with a little band, still hung upon the Roman rear, as the army retreated to Beth-horon, cutting off the stragglers, and capturing the beasts of burden, many of which he brought into the city. Cestius, as if panic-struck at the valour of the enemies whom he had come to besiege, remained inactive in his mountain-camp for three whole days, while the Jews kept an unceasing 
watch upon him from the surrounding heights, and from the towers of the city.

During this brief respite Agrippa made one more effort to mediate between the conflicting parties. He sent two persons of note, intreating the Jews to lay down their arms, and offering them, in the name of Cestius, a full forgiveness for all the past. A large party among the citizens were very willing to accept these favourable terms; and this the insurgents were aware of, and at once cut short the matter by attacking the ambassadors, one of whom they instantly slew, and wounded the other. In the midst of the tumults and disturbances that rent the miserable city on this fresh collision, the Roman general seized the opportunity to take up a position nearer to the walls, and encamped upon the hill Scopus, about three-quarters of a mile distant on the north. Three days he remained here, as he had done at Beth-horon, apparently in hope that the peace-party might prevail, and a bloodless possession be given him of the city; but the daring and insolence of the turbulent faction gave them an advantage over superior number's, and no embassage issued from the gates, "desiring conditions of peace."

On the last day of the month Tisri, (probably the middle of October, ) Cestius issued orders for the attack; the insurgents, looking down from the walls, beheld with consternation the strict discipline, compact order, and military array of the Roman army, as it marched sternly onwards; and abandoning the wall, which in this quarter was weaker than in any other, they retired to better fortified positions in the 
interior of the city, and in the Temple, which was of itself a mighty fortress. The large and loose-built suburb of Bezetha, thus undefended, was easily taken; the army, passing through it, set it on fire, and proceeded through the lower city, even to the walls of Zion, pitching their camp over against the royal palace, without meeting any resistance.

Had the Roman general been a man of vigour and decision, he might by a rapid assault have easily forced his way at this time into the upper city, and thus have finished the war at a blow; but feebler counsels prevailed in the camp: many of the chief officers, (if Josephus was rightly informed,) having been bribed by Florus, gave their opinion against such a course, and Cestius, perhaps, with little reluctance, gave up the attempt.

We, however, can discern in this imbecility the operation of One wiser than Florus. "There are. many devices in a man's heart; but the counsel of the LorD, that shall stand." $\mathrm{He}$ at whose secret bidding the princes of Zoan were fools, the wise counsellors of Pharoah became brutish, who turned the counsel of Ahithophel into foolishness, now manifestly curbed the military wisdom and energy of Rome. "The blast of the terrible ones" was turned aside for a little, that it might return with tenfold power, and sweep away, as with a tempest's violence, the doomed children of Judah from off the land.

Meanwhile a secret plot was laid by the pacific party to open the gates to Cestius, of which they apprised him by a messenger; but, irresolute as usual, and distrustful, he hesitated and lost the op- 
portunity; for the scheme was at length discovered by the vigilant insurgents, and its principal abettors were thrown headlong from the walls. For five days more the Romans made feeble and desultory attacks, which were easily repulsed from the battlements: at length Cestius drew off his force and attempted to take the Temple. From the porticoes the Jews defended their Holy House with the most determined resolution; nor could all the efforts of the enemies bring them up to the Temple wall; and at last the showers of arrows and javelins which the Jews poured down incessantly upon them compelled them to retire. But they made another attempt under the protection of a testudo, a defence formed by each soldier holding his shield above his head, those of the second rank overlapping the edges of the first, and so on ; under the cover so formed, from which the darts fell harmless, they at length approached so nigh as to undermine the wall, and brought fire to the gate of the Temple. This seems to have been the very moment of time, and this the identical action, alluded to by the Lord Jesus in those memorable words, "When ye shall see the abomination of desolation stand in the holy place,- " for at this moment alone, as yet, had the army with its idol standards, (which we presume to be meant by " the abomination,") been brought into actual contact with the Holy House. And it is remarkable that this contact was only momentary; for at that very crisis, without any perceptible reason, when an hour or two might have made him undisputed lord of the city, Cestius suddenly drew off his army, and retired without the walls. This action of 
the Roman general was so utterly unaccountable, that the Jewish historian who records it is lost in admiration at it, and is constrained to acknowledge the immediate interference of God. To us, however, with the New Testament in our hands, the retreat of Cestius is not at all unaccountable; and if we are lost in admiration, it is not at the folly of the Roman, but at the gracious and tender care of Him, who had promised to His disciples in immediate reference to these circumstances- "There shall not a hair of your head perish," and at the Divine prescience, which could foresee and predict, with minute accuracy, the acts of men so long before. These are the words of our Lord:-

When ye therefore shall see the abomination of desolation, spoken of by Daniel the prophet, stand in the holy place, (whoso readeth, let him understand :) then let them which be in Judea flee into the mountains: let him which is on the housetop not come down to take anything out of his house : neither let him which is in the field return back to take his clothes. And woe unto them that are with child, and to them that give suck in those days! But pray ye that your flight be not in the winter, neither on the sabbath day: for then shall be great tribulation, such as was not since the beginning of the world to this time, no, nor ever shall be. Matt. xxiv. 15-21.

It is recorded by Eusebius, that the Christians residing in Jerusalem did avail themselves of the signal of which their Lord's prophecy had forewarned them, by retiring from the city on the retreat of Cestius, some of them to the mountains of Perea beyond Jordan, and others to the fastnesses of Lebanon. When we consider the large number of Christian Jews, who we know from inspired testimony were resident in the holy city, amounting to 
many myriads, * and remember the jealousy of the insurgent party within the walls, it is difficult to imagine how they could have effected a retirement at any other time. So vast a host could not have stolen out unperceived by those within, and so isolated is the position of Jerusalem, so overlooked by a besieging army, that they could not have made good their retreat, in the face of the Romans, even if once outside the walls. But the retreat of Cestius, as we shall presently narrate, towards the sea, followed by the whole multitude of the warriors in Jerusalem, most marvellously opened a sudden and brief way of escape in the opposite direction towards Jordan, such as in all probability never occurred before or afterwards. The necessity of an instant seizure of the opportunity is strongly enforced in the warning, and this implies that it would be as transient as sudden: and with respect to the two other concurrent circumstances to be desired and prayed for, the season of the year and the day of the week, we would observe that the former was about the end of October, the latter was Wednesday. $\downarrow$

* See note on p. 17.

+ The day of the week I thus deduce from Josephus :-The day of the assault upon Cestius at Gibeon was the Sabbath; he was driven to Bethhoron, where he lay three days; that is (in current time, by which the Hebrews computed) till Tuesday morning. On Tuesday he pitched at Scopus, where he lay three days, that is till Friday morning; on this day, the 30 th of Tisri, he took the lower city and besieged the palace, which siege lasted five days; this brings us to Tuesday evening. Wednesday was the day of the assault on the Temple, and, as I believe, the day foretold by the Lord. I may add, that from Wednesday to the following Saturday, the 8 th of Marchesvan, the Jews were in hot pursuit of the flying foe as far as Antipatris. 
But let us pursue the fortunes of the panic-struck Roman. His sudden retirement from the Temple lighted up the waning courage of the Jews; the mouth of every street poured forth a motley host, each animated with a single desire,-to kill a Gentile. The hindmost ranks of the retreating army were sensibly thinned, before they could regain the encampment at Scopus, where they passed the night. The next day saw the proud Roman army still retreating before the elated and now innumerable Jews, who, perfectly acquainted with all the byroads and short cuts, had an immense advantage in pursuit, falling upon the enemy in flank as well as behind. The crest-fallen Romans, unused to retreat, dared not turn upon their foes, for they knew that the multitude was immense, and being heavy-armed, and knowing that their only safety consisted in keeping their ranks unbroken, they continued their slow and sullen march. The assailants, on the other hand, lightly armed, accustomed to the precipitous paths, and excited to the highest pitch, flew about the flanks and rear, making immense slaughter, almost with impunity. Multitudes of dead were strewn along the road, including many officers of distinction, and it was not without great difficulty, the loss of many men, and a great part of the baggage, that the troops at length gained their former encampments at Gibeon.

Here, distressed, but irresolute, Cestius spent two more inactive days: at length seeing the whole country roused, and the surrounding hills swarming with Jews in the greatest enthusiasm, he issued 
orders for full retreat. To reduce his incumbrances, he determined to sacrifice his beasts of burden, and to slay all except such as carried the missiles and machines of war, which he hoped to preserve. Thus his army entered upon the defiles and gorges that led to Beth-horon, once more to be the scene of

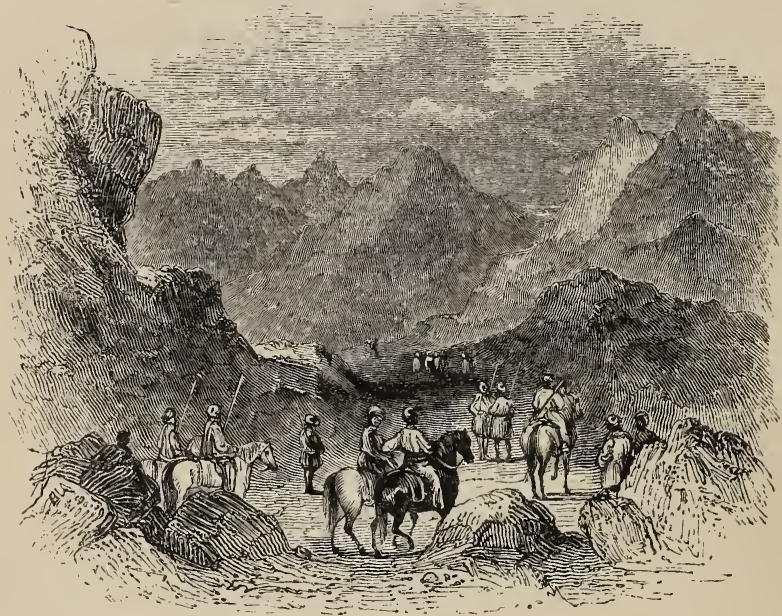

MOUNTAIN PASSES IN IUDEA.

splendid victory to the Jew. An army retreating through the mountain-passes of a hostile country is always in imminent peril, and so were the Romans here. The precipices on each side of the narrow gorges were covered with Jews, who hurled down great stones upon the ranks, while multitudes thronged around the mouths of the passes, discharging at the troops showers of arrows as they emerged. 
Where the narrow path wound round a steep and craggy cliff, multitudes were pushed down into the ravines below : and what added to the despair of the Romans, was the complete impunity of their assailants; they were over their heads, quite out of the reach of their darts, and unapproachable. Their distress was so great, that the iron-clad and iron-hearted legions of Rome at length burst out into wild cries and groans; which the exulting Jews answered with loud shouts of triumph mingled with inextinguishable rage. The retreat was a complete rout, and but for the timely fall of night, under cover of which the broken remnants of the legions escaped to Beth-horon, the entire Roman army would have been cut to pieces on that eventful day.

When morning dawned the eager Jews, who had snatched a hasty repose on the hills around, saw with pleasure the Romans encamped on an eminence, strong indeed and well fortified, but environed with daring assailants. Several of the well-known standards, the imperial eagles, with a concourse of officers, on a still higher peak, intimated the position of the general's tent. The guard was mounted, as usual in a camp, and everything indicated that there the Roman army were resolved to await the attack of their foes. But no sooner was the assault made, than it was discovered that the camp contained but a single cohort, or four hundred men, so artfully arranged as to appear much more numerous. Cestius himself had determined to make use of the hours of darkness to obtain an advantage in his flight; and thus by travelling all night, his army was about 
thirty furlongs in advance of their pursuers. The four hundred heroes, however, by the sacrifice of whom he covered his degraded laurels, were slain to a man, swept off their rocky citadel by the arrows and sling-stones of the Jews. The advantage which the general had gained saved him from being actually overtaken, though the Jews pursued him as far as Antipatris; but the whole military array, including the valuable battering engines, catapults, scaling-ladders, and other apparatus used in the sieges of those times, were scattered on the road, and fell into the hands of the Jews. With these trophies, and with incalculable booty, the heroic and victorious defenders of the Daughter of Zion returned to their beloved city, singing some of those noble hymns of praise, with which victory had been wont to be celebrated in happier and holier days.

Great is the LorD, and greatly to be praised in the city of our God, in the mountain of his holiness.

Beautiful for situation, the joy of the whole earth, is mount Zion; on the sides of the north the city of the great King.

God is known in her palaces for a refuge.

For, lo, the kings were assembled, they passed by together.

They saw it, and so they marvelled; they were troubled, and hasted away

Fear took hold upon them there, and pain, as of a woman in travail.

Thou breakest the ships of Tarshish with an east wind.

As we have heard, so have we seen in the city of the LorD of hosts, in the city of our God: God will establish it for ever. Selah.

We have thought of thy loving-kindness, O God, in the midst of thy temple.

According to thy name, $\mathrm{O}$ God, so is thy praise unto the ends of the earth : thy right hand is full of righteousness.

Let mount Zion rejoice, let the daughters of Judah be glad, because of thy judgments.

Walk about Zion, and go round about her: tell the towers thereof. 
Mark ye well her bulwarks, consider her palaces; that ye may tell it to the generation following.

For this God is our God for ever and ever; he will be our guide even unto death. Psalm xlviii.

The elated Hebrews might well believe that the ancient glory had not yet departed; they might reasonably exult in the thought that God had again visited His people. For they had plucked the prey out of the very teeth of Rome, out of the "iron teeth" of that "beast," which was "dreadful and terrible, and strong exceedingly; which devoured and brake in pieces, and stamped the residue with the feet of it." * The Roman majesty had not sustained so calamitous a reverse since the overthrow of Crassus,-more than a hundred years before,as had been inflicted on it by a host of half-armed citizens and peasants of Judea, without discipline, without military experience, without engines of war, without generals, but animated by an inextinguishable love for their country, and hatred to the enemy. Yet this little gleam of success, brilliant as it was, having accomplished a specific purpose, was but a phase of that irreversible decree of desolation which had gone forth from the LonD of Hosts against his city and people; and proved, indeed, by its effects upon them and upon their enemies, a tenfold aggravation of their inevitable ruin. 


\section{CHAPTER II.}

THE SIEGE OF JOTAPATA.

A.D. 67 .

IT was the stern policy of Rome, never to yield a conquest, and never to forgive an affront. When the first rapture of victory in the minds of the heroic men of Jerusalem had given place to reflection, they felt that the whole power of the Empire would be concentrated, if needful, to avenge the unpardonable insult of a defeat. The war must henceforth be a contest for existence; a contest between a small and almost unknown province, and the giant power that sat on the throne of the civilized world. But the Jews did not quail: they knew that failure must be utter and hopeless ruin ; but they had embarked in the desperate voyage, and nerved themselves for its vigorous prosecution. On both sides the sword was out, and the scabbard was cast aside.

The whole country was at once put into martial order; officers were chosen for the government of Jerusalem, and for the repair of its walls. Eleazar, though not without the opposition of a party, retained, as before, the supreme direction of public affairs. Skilful and valiant generals were appointed to the command of the army ; and military governors 
were set over the various districts, and the most important strongholds.

The frontier province of Galilee, which would first meet the iron storm of Roman vengeance, as it advanced from Syria, the military centre of the East, was confided to the care of Josephus, who added to the abilities of a consummate warrior the learning and accuracy of an historian, and to whom the world is indebted for the only detailed record of the interesting events of the Jewish War. Descended from a long line of priests, and connected through his mother with the royal blood of the Asmonean House, of irreproachable reputation for integrity, * this man had qualified himself by early study, by habitual temperance, and finally by travel in Italy, for the arduous duties which were now to devolve upon him, and in which he so ably acquitted himself. In the dissensions at Jerusalem he had at first been an advocate for peace, as foreseeing the hopelessness of war with Rome; but when it had actually blazed forth, he seems to have yielded to that faction, which he saw it would be perilous any longer to resist, and to have entered upon his government with a determination to defend his country to the utmost. Uniting moderation with firmness, he sought to repress the lawlessness which he found prevailing, to cement the various selfish parties in the common bond of patriotism, and to organize a system of government as well as of military defence.

* It must be borne in mind, that Josephus is his own biographer, and his readers must judge from his actions with what degree of truth he has drawn the picture of his own character. We shall afterwards see him in a much more unfavourable light. 
His own conduct, which he describes as free from tyranny and above corruption, soon endeared him to the people, and won their confidence; though, with a fickleness common to all ages and countries, they were too ready to listen to the accusations of ambitious demagogues who envied Josephus his popularity. The most remarkable of these was John of Gischala, a man who afterwards took a prominent part in the last terrible days of Jerusalem. His character is drawn by one, who spares no pains to blacken it, and who evidently mingles personal animosity with virtuous indignation; and as we have no other authority we must take the portrait as it is drawn; but we may venture to suppose that the historian's partiality has omitted to discern some redeeming traits in the character of his adversary, and has perhaps overlooked some failures in his own. Be this as it may, we are not writing the biography either of Josephus, or of John, and may, therefore, be excused from entering into their personal contentions, and from detailing the various ingenious stratagems by which they sought respectively to destroy each other, or to defend themselves.

The breathing space that followed the expulsion of the Romans from Judea was vigorously employed by Josephus in fortifying the cities in his jurisdiction. Thus, in Lower Galilee he placed in a state of defence the strong town of Jotapata, Itabyrium on Mount Tabor, Japha, Taricheæ and Tiberias : in Upper Galilee the Rock of Achabari, Seph, Jamnith, and other places were strengthened; and in the Gaulonitis the strong city of Gamala. $\mathrm{He}$ 
levied a force of more than 100,000 men, whom he provided with arms, instructed in the Roman discipline, and diligently exercised in all the manœuvres of war; appointing officers over the various divisions in full complement after the Roman manner. Out of these he chose an army of 60,000 foot, and $250 *$ horse; and having hired a band of mercenary troops to the number of 4500 , and selected a body-guard for his own person of 600 men, he awaited the approach of the Romans.

While the affairs of Galilee were thus vigorously administered by Josephus, the city of Jerusalem was not indifferent to the coming crisis. The fortifications were restored and strengthened in every part, and the streets rang from morning to night with the din of weapons forged upon the anvils of the armourers, while the youths crowded to the gymnasia, to be trained in military exercises. "Yet the moderate sort," says Josephus, "were exceedingly sad; and a great many there were, who, out of the prospect they had of the calamities that were coming upon them, made great lamentations. There were also such omens observed as were understood to be forerunners of evils by such as loved peace, but were by those that kindled the war interpreted so as to suit their own inclinations; and the very state of the city, even before the Romans came against it, was that of a place doomed to destruction."

Nor was the elation of the Jews upon the signal defeat of Cestius long suffered to remain without a

* Such is the present text of Josephus, but probably we should read 2500 , as there seems no proportion between the numbers. 
check. In the first heat of their victory a large body of men had set out from Jerusalem with the design of besieging Ascalon, a strongly walled city on the sea-coast, occupied by a small Roman garrison, consisting of no more than a single troop of horse and a cohort of foot. The commander of the fort,

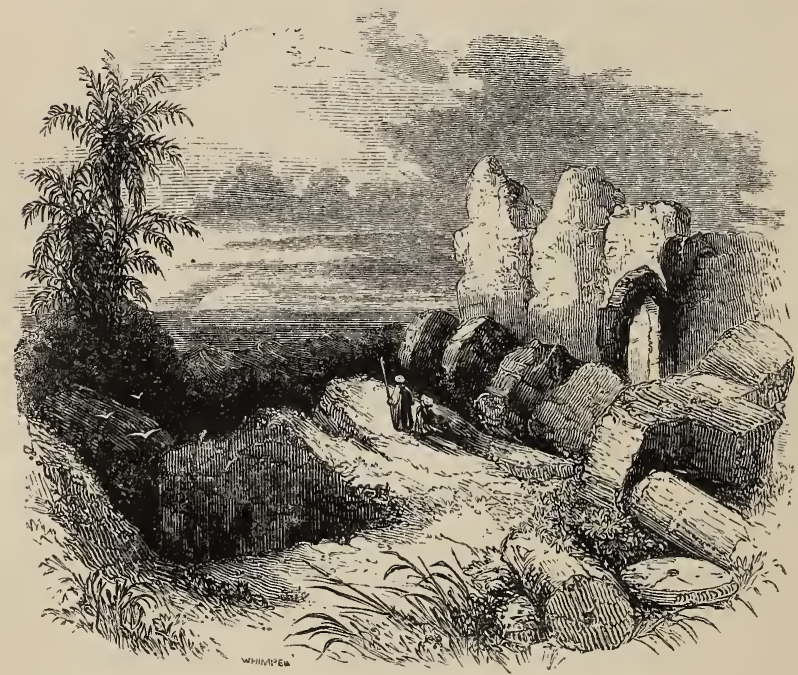

ASCALON.

however, was aware of the approach of the Jews, and placing his forces with great skill had no difficulty in beating off the undisciplined multitude with immense slaughter; 10,000 being left dead on the field, including two of their leaders, while the loss of the Romans was inconsiderable. The fierce valour of the Jews, unsupported as it was by military skill 
and discipline, increased the slaughter, as they would rather die than give way; and the nature of the ground, an unincumbered plain, afforded the best possible circumstances for the cavalry and heavy armed legionaries to fight at advantage. Yet were not the Jews so dispirited with the ill-success of their adventure, but that they soon essayed another attempt on the same city; but though reinforced by great numbers, the result was no less unfortunate, and scarcely less sanguinary, than before; for the garrison having sallied forth and formed an ambush, the inexperienced multitude fell into the snare, and lost 8000 men; while the discomfited remnant, taking refuge in a tower of a neighbouring village, were there besieged in their turn. At length the Romans, not choosing to spend much time on so insignificant a place, set the tower on fire and burnt it to the ground.

In the meanwhile the unpleasing intelligence of the defeat and expulsion of the Roman prefect and his army, was conveyed to the Emperor Nero, who was then in Achaia, by two brothers of the Herodian race, who had escaped from Jerusalem. These persons were sent at their own desire by Cestius, who instructed them to lay the blame of kindling the war upon Florus, to whom, indeed, it was most justly due. The sinister intelligence was received by Nero with affected contempt, but with real consternation, which he could but ill conceal. His s solicitude for the recovery of the rebellious province was manifested by his selection of Vespasian, the most distinguished military commander in the 
Empire, to carry on the war. Vespasian had acquired honour in Germany in the reign of Claudius, and afterwards had conquered Britain, and obtained triumphal honours. Subsequently he received two priestly offices within a short time, and was then advanced to the consulship; after which he was made proconsul of Africa. At the time of the Jewish revolt, however, he was in banishment for having had the bad taste to fall asleep while Nero was singing to the lyre his own poetical performances; and it is no small proof of the importance with which the emperor viewed the rebellion, that he repressed his personal resentment so far, as not only to appoint his offending captain to the command, but to load him with encomiums and flattering compliments.

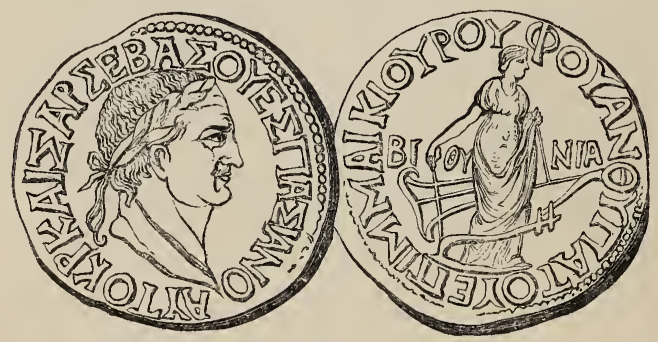

COIN OF VESPASIAN.

The experienced warrior acted with characteristic vigour and decision. Without a moment's delay he dispatched his son Titus to Alexandria, to bring with him the fifth and tenth legions, while he himself passed through Thrace into Syria, where he gathered under his command the Roman forces, 
with considerable auxiliaries from the neighbouring kings.

At Antioch the Roman general was met by Agrippa, who joined him with all his available forces, and accompanied him to Ptolemais. Here a deputation from Sepphoris, the largest city of Galilee, and a place of great strength, waited on Vespasian, offering the allegiance of its inhabitants to the Romans. For that city had revolted from Josephus, and had received from Cestius a Roman garrison, of which they now requested a reinforcement. Vespasian acceded to their desire; and in consideration of the importance of this provincial metropolis, he sent 6000 foot to garrison it, and 1000 horse to encamp beneath its walls. In hope to retake the city which he himself had fortified, Josephus marched against it; but failing both to force the walls, and to kindle the patriotism of the inhabitants, his attempt had no other effect than that of irritating the Roman troops, and provoking them to waste the whole surrounding country with fire and sword. This they did without mercy, burning and pillaging the villages, driving off the cattle, murdering the ablebodied peasantry, and leading the weaker into slavery. Thus was Galilee, to use the words of the Jewish historian, "all over filled with fire and blood; nor was it exempted from any kind of misery or calamity:" and it is a painful remembrance that recurs to the Christian's mind, that this district, which first felt the keenness of the Roman's avenging sword, and (with the exception of Jerusalem itself) felt it most terribly, was the one which had been 
above all others the witness of the teachings, the labours, and the mighty works of the Lord Jesus, yet had rejected him.

Then began he to upbraid the cities wherein most of his mighty works were done, because they repented not: Woe unto thee, Chorazin: woe unto thee, Bethsaida! for if the mighty works which were done in you had been done in Tyre and Sidon, they would have repented long ago in sackcloth and ashes. But I say unto you, It shall be more tolerable for Tyre and Sidon at the day of judgment, than for you. And thou, Capernaum, which art exalted unto heaven, shalt be brought down to hell: for if the mighty works which have been done in thee had been done in Sodom, it would have remained until this day. But I say unto you, That it shall be more tolerable for the land of Sodom in the day of judgment, than for thee. Matt. xi. 20-24.

Early in the spring Titus arrived at Ptolemais with the two legions from Egypt; for his diligence had prompted him to make the voyage from Achaia to Alexandria even before the winter was over. $\mathrm{He}$ was soon after followed by eighteen cohorts; five cohorts and a troop of horse joined the army from Cæsarea, and five troops came from Syria. The Kings Antiochus, Agrippa, and Sohemus contributed each a thousand archers, and a thousand horse, and Malchus, the King of Arabia, supplied five thousand foot, and one thousand horse. The fifteenth legion had been brought thither by Vespasian, and the whole force now united under his command amounted to sixty thousand men, besides an immense number of servants, who had been trained to military exercises, but were not counted as regular troops.

While this mighty army lay at Ptolemais, preparing to open the campaign, Placidus, the tribune who commanded the garrison at Sepphoris had been 
ravaging the country of Galilee. Desirous of performing some signal exploit before the arrival of his general, he determined to attack the fortress of Jotapata, the strongest city in the province, so celebrated afterwards for the heroic defence which it made under Josephus in person. Built upon the summit of a precipitous rock, approachable only on the north, its walls on three sides looked down into a ravine so steep and profound, that the eye could not reach the bottom. Lofty mountains encompassed it on every hand, so as to hide its situation from view, till the observer was close to it. The part of the city which was naturally more exposed to assault Josephus had encompassed with a wall of great strength; but the Roman tribune hoped to be able to get possession of it by a sudden surprise. The inhabitants of the stronghold, however, were aware of his intention, and sallying out with resistless courage, fell upon the invaders with such fury as to repel them with loss.

A few weeks sufficed to put the main body of the Roman army in marching order, when Vespasian set out from Ptolemais at its head, and fell upon Galilee. The progress of the accoutred and disciplined host is minutely described by Josephus, as it advanced in stern and regular array, but eager for the conflict. Its approach had a dispiriting effect upon the army of Josephus, which was encamped at Garis, not far from Sepphoris, so that many of his soldiers fled, before the enemy was within sight; and the Jewish commander finding himself too weak to engage the Roman forces, retired to the fortified city of Tiberias. 
The city of Gadara, situated not far from the southern extremity of the beautiful sea of Tiberias, was the first victim of the Roman vengeance. Being feebly garrisoned, it offered no resistance ; yet submission availed it as little as valour, for with merciless cruelty the inhabitants were put to the sword, and the town was burned; while a similar fate befel the helpless villages and hamlets around it.

The ill-success of the expedition which Placidus had undertaken against Jotapata only whetted the desire of Vespasian to attempt the reduction of so strong a fortress. The road which led thither was but a mountain track, absolutely impassable for cavalry, and with difficulty traversed by any but the hardy peasantry accustomed to the steep ascents and narrow ledges of a rocky country. A band of pioneers was, therefore, sent forward to level and open the road; but no sooner was this accomplished, than, before the army could take advantage of their labours, Josephus, with characteristic vigour and resolution, hasted from Tiberias, and entered the besieged city to conduct the defence in person. On being informed, by a spy, of the arrival of the Jewish general, Vespasian greatly rejoiced, as counting that the most eminent and able of his adversaries was safely shut up in a cage; for the town he already considered as within his power.

His first thought was to prevent the escape of so important a personage: so sending forward Placidus the tribune, and Ebutius, a decurion of eminent ability, with a thousand horsemen, he commanded them to invest the fortress with the utmost 
dispatch. He himself followed with the whole army on the next day, and commenced this important siege on the twenty-fourth of the month Jyar, answering probably to the beginning of May. Approaching the city on the north side, where alone the nature of the acclivity permitted the advance of an army, the Roman pitched his camp on a hill about a mile distant, in full sight of the inhabitants, whom he hoped to awe into surrender by displaying an overwhelming force. Such, for a moment, was the effect produced; but when the Jews saw that the enemy proceeded to environ them with a triple belt of troops, and that there was no possibility of egress, their native courage revived, and even desperation nerved their hearts with the fiercest valour.

The next morning the assault began; but the Jews, apparently no less eager for the fight than the Romans, had determined to give them battle without the walls, and were already awaiting the attack. Vespasian, arraying against this valiant band the archers and slingers, himself led a body of footmen up a steep acclivity, which afforded an easy entrance into the city. But Josephus, ever vigilant, saw his approach; and, sallying suddenly out with the whole remaining garrison, met the Romans, and by the impetuosity of his attack repulsed them from their vantage-ground. The battle, however, was well-contested: the Jews fought with the heroism of despair; the Romans with the stubborn perseverance of men unwont to be conquered; their skill and discipline, also, counterbalanced the fiery ardour 
of the former. At length the veil of night put an end to the contest, and the Romans drew off with their dead and wounded.

To have repelled the assault of a Roman army, commonly supposed to be irresistible, seemed to the Jewish soldiery a great achievement. Inspirited and full of hope, the next morning saw them again the assailants, and a still more desperate battle than before was maintained on the slope of the hill; the Romans, incensed that an enemy so despised should be able to hold them in check for a single day, fought with scarcely less fury than the Jews, but again with no better success. And thus for five successive days did the valiant little mountain garrison dispute with the whole force of Vespasian's mighty army the approach to their fortress.

At length the Roman general, having called a council of war, consulted on the most effectual mode of prosecuting the siege. It was decided to raise an embankment against that part of the wall which could be approached: and the whole army was accordingly employed in collecting materials for its formation. The forests of the embosoming mountains fell before the axe, and the earth and stones from the vicinity were soon accumulated in vast quantities. The Jews looked on from the walls with dismay as the work proceeded, and continually showered down arrows and javelins on the workmen, who, to protect themselves, wove a sort of hurdles or wattles of basket-work, which they spread over their heads in a sloping direction. Under this defence the soldiers could labour in 
safety; nor could the huge stones which the garrison then hurled down upon them, do more than startle them by their noise; for the elasticity of the green and tough branches with which the hurdles were made, yielded to the weight of the stones, without breaking, and, rebounding, threw them off. In order more effectually to prevent the annoyance of these missiles, Vespasian ordered up his military engines, of which he had one hundred and sixty, some of which hurled against the battlements stones of a hundred pounds weight with great force; others threw lances, or arrows, or combustibles set on fire, so that the defenders could no longer stand upon the wall. With indomitable courage, however, they were no sooner driven from one resource, than they adopted another; and now they rushed forth in bands, tore away the protecting hurdles, slew the workmen, scattered the earth, and set fire to the timber; until Vespasian perceiving that the isolated manner in which the labourers worked, afforded an impunity to these attacks, ordered the parties to be united, and bringing up a part of the army as a defence, put an end to this impediment.

Nor was Josephus idle while this great embankment was erecting: he watched it growing higher and higher, until, when completed, it towered up nearly to the original height of the city wall: but in the mean time he had diligently been adding. to the defences, until he had raised the walls to the height of twenty cubits. In order to effect this, he had stretched the raw hides of oxen on stout poles in front of the workmen, to receive the missiles which 
the engines were continually discharging; by this ingenious contrivance their force was broken, the soft and yielding hide receiving in its tough concavity the stones and darts, and its wetness quenching the fiery arrows. When the new structure was carried to its height, the Jewish commander added to it battlements, and further strengthened it with towers, to the no small mortification of the besiegers.

The building of this wall no less elated the Jews than it annoyed the Romans; they made fresh sallies every day, creeping out in small parties, plundering the troops, cutting off stragglers, and especially setting fire to the works and engines. At length Vespasian, finding his army dispirited by this petty but irritating warfare, gave orders that they should avoid these conflicts, determining to blockade the city, since it seemed impracticable to take it by assault, and hoping soon to starve it into surrender. The garrison, however, was abundantly supplied with provisions; water alone was a scarcity. There was no spring in the city, the inhabitants being dependent on rain-water, which, falling copiously in the winter, was collected in pools and tanks: in summer a shower is scarcely known, and as it was now the month of May, there was no hope of recruiting the supply, which, from the addition of the garrison to the ordinary inhabitants, already began to run short. The prudence of Josephus, who found it needful to distribute so valuable a commodity by measure, reminding the people continually of their want, had the effect usual in such cases, of increasing their desire for it, so that they seemed as if already 
reduced to extremities. Nor were the Romans ignorant of their necessity, for from the heights that surrounded the city, they could observe the inhabitants daily crowding to the place of supply with their vessels, and easily conjectured the cause.

To disappoint the expectations of the enemy, Josephus had recourse to one of those expedients which never present themselves to any but masterminds. He ordered that a great many garments should be steeped in water, and hung over the battlements, till the walls ran down with the moisture that dripped from them. The Romans were astounded, and at once concluded that such a waste of water could not indicate a condition of scarcity. The thought of starving the garrison, therefore, by blockade, was relinquished, and the former mode of proceeding resumed, of endeavouring to storm the walls. Thus the stratagem was successful; for the Jews greatly preferred the chances of stern warfare, to the slow but certain horrors of famine and thirst.

Some supplies were obtained from without the walls. In the ravine on the western - side there was a sort of track which led down its precipitous sides, so narrow, rough, and broken, that it could scarcely be traversed except by persons familiar with it, and by them only with difficulty and hazard; so that it had escaped the notice of the besiegers. By means of this path Josephus opened a communication with his friends in the mountains, and obtained a seasonable supply of many necessaries ; for his messengers were instructed to pass through the valley only by night, and to cover themselves with the woolly skins 
of sheep, so that creeping along by the sentinels upon all fours, they might be mistaken for dogs. After sometime, however, this artifice was discovered, and guards were posted at the place of exit.

About this time Josephus began to think of providing for his own safety by escaping from the beleaguered city; but induced by the entreaties of the people, who besought him with tears not to desert their failing fortunes, and fearful also lest, if he refused, they might detain him by force, he relinquished his design, and endeavoured to raise their sinking valour by exciting oratory, and by the influence of his own example. He at once devised and headed the most desperate sallies: rushed with irresistible fury on the out-guards, penetrated even to the Roman camp, tore down the tents that were upon the embankment, and set fire to the works. For several days in succession these intrepid attacks were continued; the active and half-armed Jews having greatly the advantage over the legionaries burdened with the weight of complete armour; until Vespasian, seeing his troops distressed with this unequal warfare, determined to bring up his last resource,-the terrible batteringram. This hewas able to do now, for he had, at length, carried the bank nearly up to the city-wall.

The battering-ram was the most formidable implement of ancient artillery, and was the grand means of taking a city by storm. It consisted of an immense beam of timber, armed at one end with a solid mass of iron, commonly shaped like a ram's head; the other end was furnished with ropes by which it was worked. The beam, when prepared for 
use, was slung in the middle, by a stout rope or chain, from another beam overhead supported by tall upright posts at each end. This mighty engine was put in motion by the united force of many men, who by means of the ropes, drew back the beam; then, letting it go, the iron ram's head swung against the wall with such a shock, that the most solid and compact

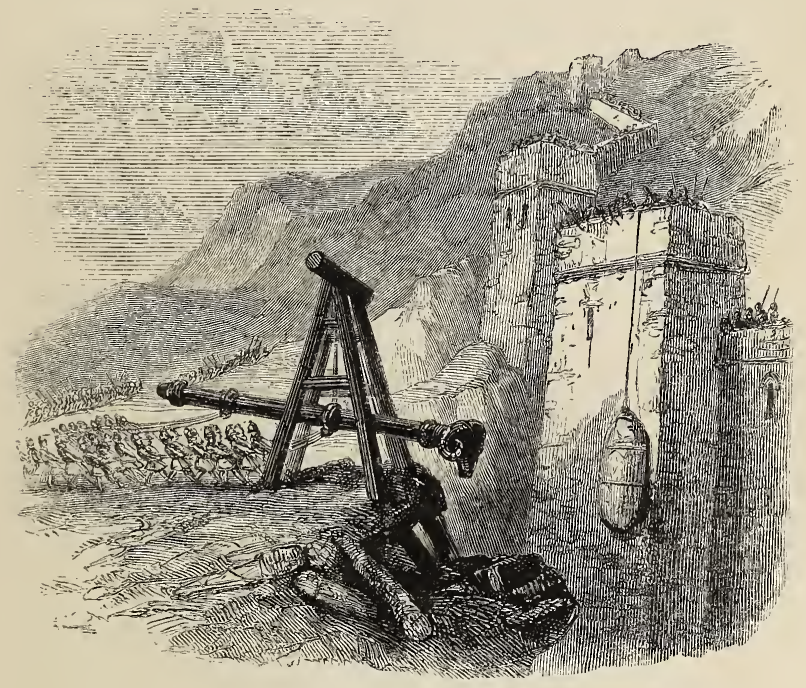

BATTERING-RAM.

edifice could rarely resist its repeated blows. The vibration soon shook and loosened the structure, and perseverance was sure to be rewarded with success.

The first blow of the mighty ram falling upon the doomed wall of Jotapata, caused the whole city to tremble; and the garrison, who had little appreciated the power of the engine, at once sent up a terrific 
cry, as if the towers and battlements were already falling about them. Nor could any ordinary device avail to repel or prevent its attacks, for the whole frame-work of the ram was encased in hurdles, and roofed with raw hides, so as to render the projection of missiles and even fire-darts of no avail, had they been used; but the catapults and the ballistæ were sweeping the walls, so that the Jews could not get upon the battlements to throw them.

The inventive genius of Josephus, however, was not yet exhausted. As the ram continued incessantly battering at the same spot, the Jewish commander perceived that the solidity of the wall could not much longer resist the repeated blows; in order, therefore, to break their force, he filled large sacks with chaff, and suspending them by ropes from the battlements, hung them in front of the iron head of the engine. The violence of the blows was much deadened by the passive resistance of this halfyielding substance; nor could the Romans readily elude this stratagem; for though they removed their machine to another part of the wall, the sacks could be removed much more easily, and be beforehand with it. At length the army, fastening scythes to the end of long poles, managed to cut the ropes that held the sacks, and so got rid of this ingenious impediment.

Incited again to rage and despair by the renewed blows of the heavy battering-ram, and perceiving that the newly built wall was beginning to yield, the Jews rushed forth from the gates in three parties, carrying fire and combustibles, and so vigorously 
attacked the works and machines as to do a great deal of damage before the army could prevent it; for the dryness of the materials, aided by the pitch and sulphur which were among them, readily caught fire, and burnt with a fierce flame not easily extinguished. Such was the impetuosity of these desperate assaults, that they sometimes bore all before them; so that in one of the conflicts even the renowned fifth and tenth legions were simultaneously put to flight, and the machines and other works belonging to these divisions were burned, and the materials which resisted the fire were buried.

While these furious contests were raging without, a daring exploit was performed, which received universal applause. A Jew, named Eleazar, standing on the wall, threw from him a stone of vast weight upon the ram, with so true an aim that the iron head was broken from the beam. Seeing his success he instantly leaped down, and, catching up the head from the midst of the astonished Romans, bore it back to the top of the wall. A shower of darts fell around his unprotected person as he was climbing up, but, though transfixed by five javelins, he gained the battlements, displayed his prize in triumph, and then fell dead.

But such exploits as these could not avert the ultimate issue of the conflict: another head was fitted to the beam, and before a day had elapsed the terrible machine was dealing its blows with the same regularity as ever; while the catapults and ballistæ hurled their huge stones and showers of darts with incessant activity, sweeping off the groups of Jews 
who showed themselves on the battlements. Some of these engines were truly terrific; stones of a hundred weight were hurled with immense force to a great distance; the noise that accompanied their discharge, and the crash that announced their fall, increased the terror with which they were regarded. Some horrible instances are given by the ancient historians of the effect of these missiles, of which, omitting others more dreadful, we will mention one that occurred in this very siege; a man who was standing on the wall close to Josephus, was struck on the neck by a stone from the catapult, and the severed head was hurled by the impetus to the distance of three furlongs.

And now the dreadful night was come when the strength of the solid wall could no longer resist the thundering strokes of the mighty ram. On the previous evening a slight wound received by Vespasian had increased the exasperation of the army, and with a deeper determination to wipe out the disgrace of delay, and with loud shouts and cries of rage, they rushed impetuously onward to the foot of the walls. The engines were plied with double vigour ; the hurtling storm of stones and darts filled the air; the latter piercing the bodies of whole groups of men, and the former crushing all before them, and sweeping a passage for themselves through the living ranks; the pinnacles and battlements of the wall, and the angular projections of the towers were torn off by the forceful masses, and occasionally a turret would fall with a frightful crash. "But still Josephus and those with him, although they were struck 
dead one upon another by the darts and stones which the engines threw upon them, yet did not desert the wall, but fell upon those who managed the ram, under the protection of the hurdles, with fire, and iron weapons, and stones; and these could do little or nothing, but fell themselves one after another, while they were seen by those whom they could not see, for the light of their own flame shone about them, and made them a most visible mark to the enemy, as they were in the day time, while the engines could not be seen at a great distance, and so what was thrown at them was hard to be avoided:

The noise of the instruments themselves was very terrible, the sound of the darts and stones that were thrown by them was so likewise; of the same sort was that noise the dead bodies made, when they were dashed against the wall ; and indeed dreadful was the clamour which these things raised in the women within the city, which was echoed back at the same time by the cries of such as were dying; while the whole space of ground whereon they fought ran with blood, and the wall might have been ascended over by the bodies of the dead carcases; the mountains also contributed to increase the noise by their echoes; nor was there on that night any thing of terror wanting that could either affect the hearing or the sight: yet did a great part of those that fought so hard for Jotapata fall manfully, as were a great part of them wounded." *

'Towards the morning-watch the massive stones of the wall, which had been loosening the whole night,

* Josephus, Wars, III. vii. 23. 
gave way, and a great breach yawned in the solid structure. The Romans shouted at the sight, but the poor Jews felt that all was lost for them, and that nothing remained but to sell their lives as dearly as possible. And who shall paint the agony of the timid women and helpless children, when they saw that now no barrier lay between them and the brutal, infuriate Roman soldiers, and knew that nothing awaited them but a horrible death, or a captivity which would be even more intolerable!

In the morning, after a brief interval of repose, Vespasian prepared for the assault in the following order. A body of men, selected from the bravest of the cavalry, were made to dismount, and stationed in triple rank in front of the breach; they were encased in complete armour, and held long poles in their hands, that they might mount the breach as soon as the bridges were laid. Behind these were placed the flower of the infantry. The remainder of the horsemen were extended around the city, upon the adjacent hills, to cut off such of the garrison as should attempt to escape in the assault; and outside all were placed the archers, who were mostly mercenaries. Several feint attacks were directed to be made at various parts of the walls, to call off the attention of the garrison from the defence of the breach.

But the generalship of Josephus was not inferior to that of his experienced antagonist. The defence of the sound parts of the wall he entrusted to such as were infirm from age, sickness, or fatigue; while he mustered his whole force where he well knew the assault would really be made. Nor did he shrink 
from taking his own share in the imminent peril. Having ranged his most vigorous soldiers in the breach, he selected six of tried valour, whom he placed in the foremost rank, to bear the first brunt of the onslaught; and of these six he himself was one. He warned his men of the terrific shout with which the legionaries would rush to the combat, that they might not be paralyzed by it, and of the shower of arrows with which their attack would be covered. Against the effect of the former he recommended them to stop their ears, and the latter he instructed them to avoid, by suddenly bending themselves forward at the moment of discharge and covering their heads with their uplifted shields. But as soon as they saw the planks laid for the enemy to ascend the breach, they were ordered to rush out in a body, not with any hope to preserve the city,-for that was now impossible,-but to revenge their calamities as much as they could. To incite their fury, the commander, in brief but burning words, set before their imagination their aged parents massacred, their tender babes dashed in pieces, and their wives and daughters abused, by the brutal and implacable foe before them.

That the courage of his troops might not be impaired by the cries of the women and children, Josephus had commanded that these should be confined to their houses, not without threats of immediate punishment, if they did not restrain their grief; for when these helpless and hopeless creatures had looked around, and seen not only the walls thrown down, but the city encompassed with a three- 
fold army, the glittering swords in the hands of the soldiery, the sun gleaming at every point from the steel-clad hosts on the surrounding hills, and the darts in the hands of the Arabian archers, - and marked the fierce and ruthless countenances that glared upon the devoted city, such a wailing shriek had suddenly arisen and been re-echoed from the mountains, as if the full tide of their misery had been already overwhelming them.

And now the trumpets of the legions sounded for the assault, and the army sent forth such a shout, that the hills rang again; at the same moment the air was filled with a cloud of arrows that intercepted the light of the sun. But the Jews, acting according to their instructions, suffered little from either; but as soon as the bridges were laid, they rushed out upon them, before they were occupied by the besiegers, and a furious fight took place in front of the breach. The legions, kept at bay for a while, at length uniting into a compact mass, with their shields interlocked above their heads, forced back the valiant defenders, and had already reached the wall, when another manœuvre of the fertile mind of Josephus once more turned, for a moment, the tide of conquest.

A brief space of time sufficed to heat the oil which in that country was found in abundance in every house; it was soon brought in large quantities to the breach, and at once poured down in a boiling state on the heads of the crowded hosts that were pressing upwards. Neither their compact array, nor their interlocked shields, nor their iron armour, 
could protect them from this terrible enemy; it trickled down within their coats of mail, spreading over their bodies like living flame, and eating the flesh from the bones. The armour in which the unhappy men were enveloped only rendered the torture more intolerable; the ranks were broken, many of the sufferers fell down and writhed in anguish, many plunged headlong from the bridges, and others rushed

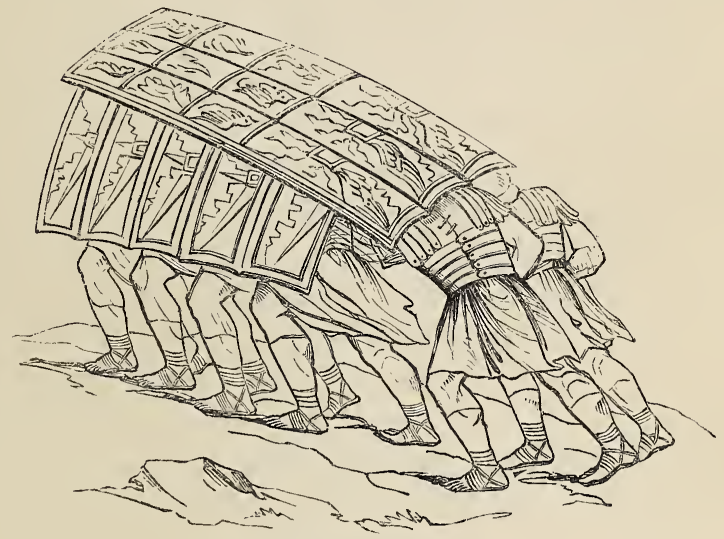

TROOPS WITH LOCKED SHIELDS.

back upon the weapons of their friends pressing on from behind. The advantage thus gained was at once improved by the indefatigable Jews; for they immediately poured upon the sloping planks of which the bridges were formed, a quantity of boiled herbs, by which they were rendered so slippery, that the Romans found it impossible to maintain their footing. All their attempts to ascend were unavailing; they continually fell down, or slid back 
upon the bank; while the Jews, now freed from the necessity of fighting hand-to-hand, threw missiles upon them with great execution. At length, on the approach of night, Vespasian called off his baffled soldiers, having sustained a heavy loss of men, both killed and wounded, while that of the Jews was not inconsiderable.

Thus once more repulsed, the Roman general despaired of entering the city by the breach while it was thus vigorously defended. He then commanded the banks to be raised still higher, and three towers to be erected on them, each fifty feet in height, which he overlaid with plates of iron, that they might not be easily set on fire, and that they might acquire stability from their weight. On the summits of these towers were stationed slingers and archers, with the lightest of the engines for throwing stones and darts ; and these, being now in height far above the city-wall, were able to pour down their missiles with great advantage; while the Jews found it impossible to maintain the unequal conflict with an enemy to whose attacks they were fully exposed, but who was wholly beyond the reach of their weapons. All they could do was to make occasional sallies, which though attended with much loss to themselves, did little damage to the foe.

Still the Romans were kept without the walls, notwithstanding that every day the advance of their works was more and more perceptible; and still the poor beleaguered city bore up manfully under its misfortunes, though from the most sanguine of its inhabitants hope had long departed. At last, on 
the forty-seventh day of the siege, and ten days after the breach had been made in the walls, the gigantic embankment of the Romans overtopped the battlements of Jotapata. But this unhappy city was destined to fall by treachery, not by force. On this fatal day a renegade Hebrew stole from the devoted place, and, crawling to the Roman commander, purchased his own base life by a betrayal of his city and people. This treacherous miscreant represented that now few men were left in the garrison, and those so worn with fatigue, with watching, and with wounds, that even the very sentinels could not perform their duty; but that in the last watches of the night they were sure to be asleep. The deserter, therefore, advised that a body of soldiers should steal silently up to the breach, just before day-break, kill the sentinels, and take the city-gates before the alarm could be given.

The caution of the Roman veteran made him receive this information with reserve. He strongly suspected another of those stratagems which had already so effectively told upon his troops. The devotion of the Jews to their common cause, and their incorruptibility, had been extraordinary: the prisoners taken in the siege had alike despised the promises of reward, and the infliction of torments. One of these, after having been horribly tortured with fire, was at length crucified; yet he not only steadfastly refused to communicate any thing of the state of the garrison, but smiled in scorn upon his murderers when in the agonies of death.

As the story told by the renegade, however, bore 
evidence of extreme probability, and as, in case of its falsehood, little damage seemed likely to accrue from the experiment proposed, Vespasian, ordering the man to be kept in strict custody till the event should be known, appointed the next night for the silent assault.

On the morning of the first day of the month Tamuz,-the last morning that unhappy Jotapata was destined to see,- - a dense and blinding mist brooded over the city. The light of the stars,- " the burning stars of that pure sky," that commonly sparkled radiantly upon the mountain fortress,was now eclipsed; and it was in deep darkness that the Roman soldiers selected for the assault set out upon the enterprise. Slowly and noiselessly they mounted the machines, and climbed the breach: Titus, the illustrious son of Vespasian, was the first to set foot upon the wall; after him came Domitius Sabinus, the tribune, and a few men of the fifteenth legion. They found the watch sunk in a slumber deep as death, as the deserter had reported; and these they instantly slew, without noise. The way being thus clear, the tribunes, Cerealis and Placidus, led on the troops under them, and the prize so long desired was theirs at last; Jotapata was in the possession of the Romans.

Overpowered with fatigue, the people slept soundly, unconscious of their danger, though now it was broad day light, and the Roman army was now crowding the streets; and when the keen edge of the sword at length aroused them from their slumber, so dense was the fog, that it was some time 
before they perceived the full extent of their misery, or knew that the city was taken. Yet the merciless conquerors left them not long in doubt; pity was unknown to their breasts; and now they were exasperated to the highest degree by the recollection of the brave defence which had so long baffled them of their prey. The sword therefore fell without compassion; old and young, man and maiden, infant and suckling, were hewn to pieces, and horrors undescribed reigned without control. The portraiture of the cruel one that now raged rampant in Judah's cities had been long before drawn by the pen of Hrm that cannot err, and that cannot lie :-" a beast dreadful and terrible, and strong exceedingly; and it had great iron teeth; it devoured and brake in pieces, and stamped the residue with the feet of it." The righteous LorD of Hosts had let loose the Roman "beast," upon the sinful people of His heritage, and fearfully he did his work. Down the steep and narrow streets the iron-clad legions poured, slaying and trampling under their mailed feet the poor helpless throngs that now made no resistance; and many of the men seeing that all was lost, preferred to die by their own hands. A few of the boldest took refuge in a tower, and for a while made a show of defence; but seeing themselves encompassed by the enemy, they at length submitted their necks quietly to the sword. Josephus reports, what indeed is scarcely credible, that in that day of horrible carnage, the Romans lost but a single man, a centurion, who was slain by a Jew to whom he had offered quarter. 
The whole of that long day was spent in massacre; and when night at length fell, none of the people of Jotapata remained alive, but the few that had concealed themselves in wells, and caverns, and other secret hiding places. The next day these were carefully searched for ; the men were butchered, and the women and children, to the number of twelve hundred, were reserved for a horrible captivity. Forty thousand Jews slain during the siege offered the first sacrifice to Roman vengeance. And now the city was razed to the ground, the fortifications were demolished, and but a heap of blackened ruins remained to tell where the gallant mountain-fortress had once stood, proudly rearing its beautiful head to the skies.

Is it nothing to you, all ye that pass by? behold, and see if there be any sorrow like unto my sorrow, which is done unto me, wherewith the LORD hath afflicted me in the day of his fierce anger.

From above hath he sent fire into my bones, and it prevaileth against them: he hath spread a net for my feet, he hath turned me back: he hath made me desolate and faint all the day.

The yoke of my transgressions is bound by his hand: they are wreathed, and come up upon my neck: he hath made my strength to fall, the Lord hath delivered me into their hands, from whom I am not able to rise up.

The Lord hath trodden under foot all my mighty men in the midst of me : he hath called an assembly against me to crush my young men: the Lord hath trodden the virgin, the daughter of Judah, as in a wine-press.

For these things I weep; mine eye, mine eye runneth down with water, because the comforter that should relieve my soul is far from me : my children are desolate, because the enemy prevailed. Lam.i. $12-16$. 


\section{CHAPTER III.}

THE SUBJUGATION OF GALILEE.

$$
\text { A.D. } 67 .
$$

Immediately after the fall of Jotapata, the Roman general removed to Cæsarea, carrying with him Josephus, who had been found secreted in a cavern after the destruction of the city. With consummate address, the crafty Jew assumed the oracular tone of a prophet, and confidently foretold to Vespasian his accession to the imperial throne; one of those shrewd guesses which might well occur to a speculative mind under the circumstances, and of which the promulgation naturally tended to the fulfilment. His bold prediction had the effect of securing the favour of Vespasian, which was the object he doubtless had in view; and his youth, handsome figure, and chivalrous bravery recommended him strongly to the generous Titus. Henceforward we find Josephus in the Roman camp till the end of the campaign; having turned his back upon the falling fortunes of his country, he was content to remain the pliant sycophant, first of Vespasian, and then of Titus; to smile and flatter and play the courtier among the idolatrous heathen, while he witnessed the last throes and pangs of his dying nation. How unlike to Moses, and other of the ancient worthies of this 
illustrious race, who, in times of national sorrow, nobly relinquished their own individual ease, "choosing rather to suffer affliction with the people of God, than to enjoy the pleasures of sin for a season!"

The little flourishing town of Joppa, the principal sea-port in Palestine, had been burnt to the ground by Cestius, and its inhabitants put to the

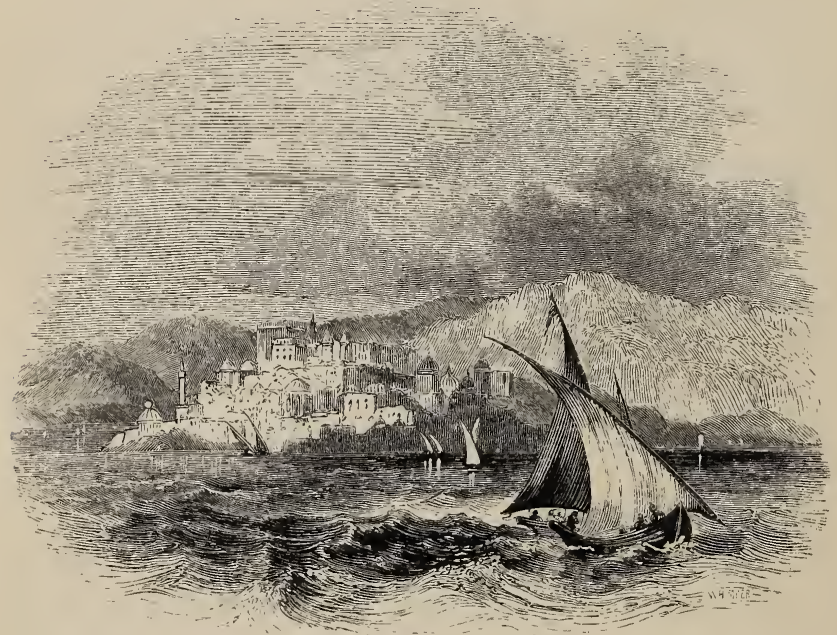

JOYPA.

sword. Since then it had been partially rebuilt by refugees from the desolated country around, who had engaged in a sort of indiscriminate piracy in the neighbouring seas, and made this their resort. So annoying had the depredations of these buccaneers grown, that marine commerce began sensibly to suffer; and one of the first expeditions of Vespasian 
after his arrival at Cæsarea, was to dislodge and. destroy the nest of pirates at Joppa.

This little ancient place was built on the slope of a steep, rocky hill, rising from the shore, the projections of which enclose a shallow harbour, exposed to the north. A narrow ledge of rocks forms a sort of channel, in which small vessels can ride at anchor, but not without danger, which becomes imminent when the wind blows heavily from the northward; hence a gale from this quarter is much dreaded, and is known as "the black north wind." On the approach of the Roman troops the inhabitants fled to their galleys, and moored beyond the reach of the arrows, hoping to put to sea in the morning; but with the day came on a terrible storm, with a heavy sea. Cooped up in the narrow channel, with no searoom, with an iron-bound shore behind them, the poor creatures looked out upon the blackening northsky to sea-ward, and felt the straining of the cables, which alone kept them from destruction, as the howling gusts swept more fiercely by, and the crested billows dashed more and more furiously upon the rocks. No hope of safety lay in slipping their moorings, and running before the wind upon the shore, for the beach and rocks were covered with the ferocious soldiers, who could ill brook being disappointed of their prey. At length, as the tempest increased, one by one the strong ropes yielded to the strain, and the ships, driving before the gale, and striking one against another, were all dashed in fragments among the ragged and bristling rocks that lined the shore. The unfortunate mariners all met a 
violent death ; many were drowned; many more were beaten and torn to pieces by the force with which the boiling surf whirled them among the sharppointed rocks; and the few that reached the shore alive were instantly slain by the merciless Romans. A fearful and horrible sight was presented along that dismal shore; four thousand human bodies, mangled and bleeding, were tossing in its waves, and the surf that rolled heavily up and curled over in long cataracts, was red with the blood of the dead. Such a scene, it might be thought, would have melted a heart of stone; but the name of pity was unknown to the Roman soldiers; and, savage that the work of destruction had been so largely taken out of their hands, they fell upon the helpless women and children that remained in the town, and utterly destroyed them all. The ill-fated city was then, a second time, levelled with the ground.

After a few days spent at Cæsarea by the sea, Vespasian accepted an invitation to visit Agrippa, at Cæsarea Philippi. Here the king entertained his illustrious guest for twenty days; after which the latter thought it well to subdue some manifestations of hostility in some of the cities of Galilee, which were in the government of Agrippa. But first he sent a peaceful embassy to them, to exhort them to submission, and to show them the futility of resistance;-while his army encamped at a few miles' distance. On the arrival of the fifty horsemen, with the decurion at their head, before the walls of Tiberias, the whole body alighted to tesrify that their errand was pacific; but a fierce band of what Jose- 
phus calls "robbers," but what they would themselves have designated "patriots," under the conduct of one Jesus, the son of Shaphat, suddenly rushed out upon the deputation, put it to flight, and led some of the horses back in triumph to the city.

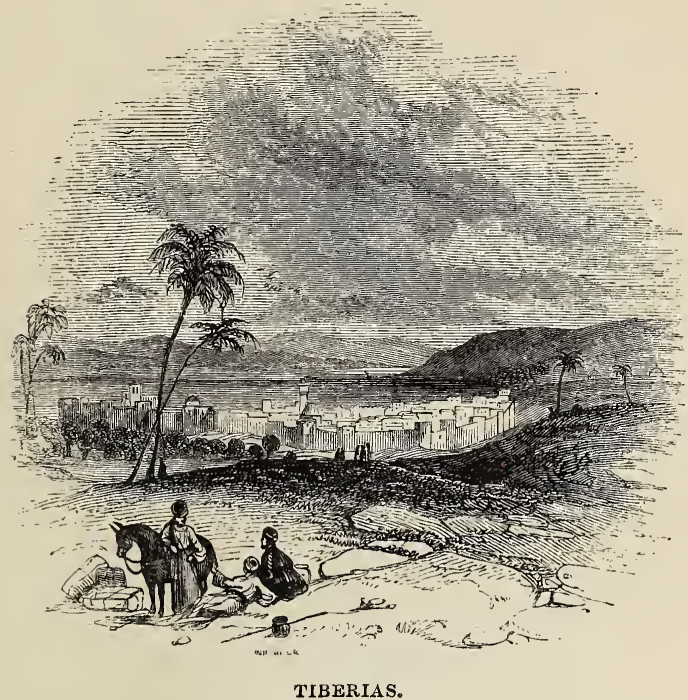

The majority of the inhabitants were disposed to submit to the Roman yoke; the rather as their own king, Agrippa, had openly espoused the Roman cause: but the fiercer and more impetuous spirits had hitherto so cowed the more peaceable, that the latter had found no opportunity of following their inclinations. Alarmed, however, by the daring act of the "patriot" leader, the chief of the rulers and elders of the city went to Vespasian's camp, and 
intreated him not to visit upon the peaceable the madness of a few turbulent men, from whom they earnestly desired to be delivered. By such intercessions, accompanied by the good offices of Agrippa, the general was softened, and engaged to send another deputation to receive the fealty of the good people of Tiberias. Before this was accomplished, the insurgent leader and his party judged it prudent to provide for their own safety by retiring to the neighbouring city of Taricheæ.

But a fearful doom awaited the unhappy city, which the insurgent chief had chosen as his refuge. It was more turbulent than Tiberias, and its haughty spirit of resistance was now increased by the accession of many of that party, who were thronging from all parts into it, relying on its strength and its maritime situation. Taricheæ, like Tiberias, had been fortified by Josephus, during his administration of the affairs of Galilee; but the latter had been, in this respect, more highly favoured than the former. Both were situated on the shores of the beautiful Lake of Gennesaret or Sea of Tiberias, mentioned in the Gospels-Tiberias being on the western shore, Taricheæ near the southern extremity, close to the spot where the River Jordan emerges from the lake.

The beautiful expanse of water, whose ripples kissed the white walls of three-and-twenty other cities, that lay on its smiling banks, is known by many names. In the Holy Scriptures, it is called the Sea of Cinnereth and Cinneroth, the Lake of Gennesaret, the Sea of Tiberias, and the Sea of 
Galilee; the Jewish rabbins use the terms Sea of Gennesar, and Sea of Tabaria, which last name it still bears. Ancient and modern writers are eloquent in praise of its waters and of the country which surrounds it. The very name of Gennesaret is said to be derived from the delightful gardens and paradises which abounded there; the word signifying "princely gardens." The Talmud asserts, that

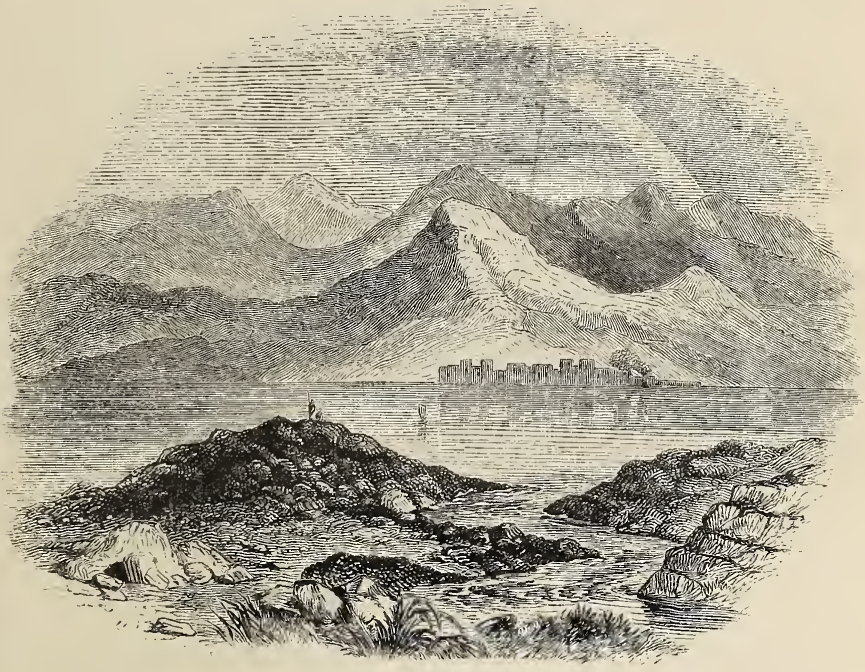

THE JORDAN LEAVING THE LAKE.

"of the seven seas which God created, he chose none for himself but the Sea of Gennesareth." Josephus is more diffuse in his eulogium. He tells us that the sweetness of its waters, and their agreeable qualities for drinking, are so great as to make the water of other lakes seem as if it were drawn from 
a marsh, in comparison; that they are clear and sparkling, not bounded by a morass, but rippling up to the sandy shores, or pebbly beaches; that though temperate when drawn, and milder than the waters of a river or fountain, yet they are always cooler than one would expect in so exposed a situation; and that if kept in the shade in the open air, they become as cold as snow. Of the vicinity, he de-

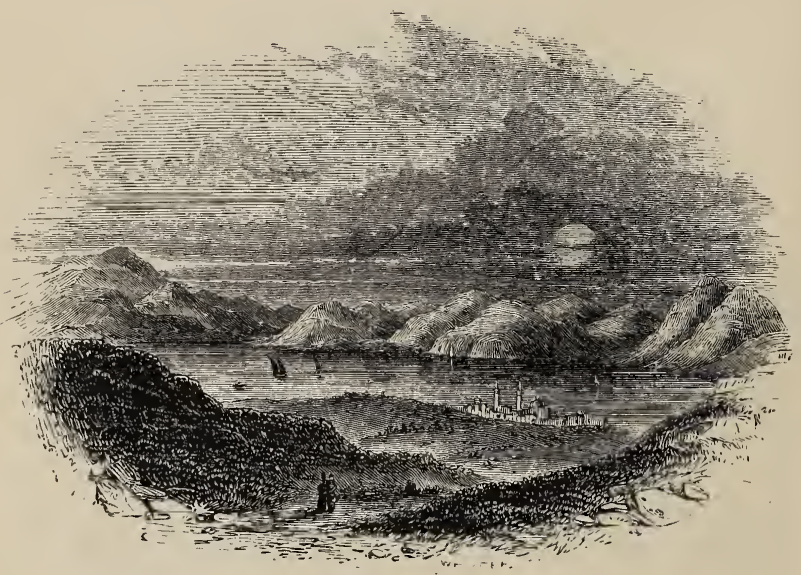

SEA OF TIBERIAS.

clares that the soil is so fertile that all sorts of trees grow, or are planted there, and that the temperature of the air is so balanced as to suit the productions of various climates. Thus walnuts, the fruit of a cold region, grow there in abundance; palm-trees, natives of the sunny tropics, also flourish; and the fig-tree and the olive, which require an intermediate air, likewise come to perfection in this delightful 
region. "It is a kindly contention of the seasons, as if each one laid claim to this country; for it not only nourishes different sorts of autumnal fruit beyond men's expectation, but preserves them a great while; it supplies men with the principal fruits, with grapes and figs continually, during ten months in the year, and the rest of the fruits, as they become ripe together, through the whole year; for besides the good temperature of the air, it is also watered from a most abundant fountain."

Here, a few years before the time of which we are speaking, the Lord Jesus had spent the greatest part of his life, when tabernacling in the flesh. A few miles to the westward of the lower extremity of the lake, lay Nazareth, "where he had been brought up," and the mountain-brow, from which, on the opening of his gracious ministry, the benighted people of Nazareth had attempted to throw him headlong. Within sight of his own city, rose the beautiful Mount Tabor, believed to be the "high mountain apart," where the glory of the veiled Deity for a moment beamed forth on his wondering disciples, where "his face did shine as the sun, and his raiment was white as the light." The little town of Nain lay at the foot of this hill; in which the desolate heart of the bereaved widow was gladdened by the restoration of her only son to life. At about the same short distance from Nazareth, but on the opposite side, was Cana of Galilee, the scene of the first miracle which the blessed Lord performed,- the change of the water into wine. Nearer to the borders of the blue lake was Capernaum, the chief place of 
his residence during his ministry, which witnessed so many of his mighty works; and Chorazin and Bethsaida too, whose obdurate unbelief constrained his meek and gentle lips to pronounce upon them a woeful doom. Here, on the grassy banks, washed by the pellucid tide, he often stood, telling the message of life, and preaching the Gospel of the kingdom to the multitudes who listened to his words; here he walked to and fro from city to city, and from village to village, "healing all manner of sickness and all manner of disease among the people;" here he fed the hungering thousands with a few small loaves and fishes, multiplied by his own creative energy. On the placid waters, reflecting with mirror-like perfection the sweet blue sky, he had sat in the little fishing-boats of Andrew and Peter, or the sons of Zebedee, "thrust out a little from the land," and taught the crowds that stood on the shore, or had rested from his toils, while his disciples let down their nets for a draught. When furious blasts had come down upon the lake, lashing its waves till they threatened to engulph the feeble bark, he had risen up in the majesty of his power, and stilled the tempest with his word. And once, when in a dark and stormy night, the disciples were alone, toiling with rowing against a contrary wind, and tossed with waves in the midst of the sea, Jesus had suddenly appeared, mysteriously walking over the crested billows, at first to their terror, but soon to the removal of their anxieties and the relief of their toils. Nor may we forget that it was on the verdant shores of this lake that one of the most important of those in- 
terviews took place, in which "Jesus showed himself to his disciples after that he was risen from the dead."

But now very different were the scenes that were acting around the Lake of Gennesaret, and very different was the character of that Jesus, the son of Shaphat, who was one of the leaders in the bloody tragedy that was soon to redden its peaceful waters. For, in pursuit of this daring chief, Vespasian had now advanced upon Taricheæ, and, having pitched his camp a few miles from the city, was beginning to fortify his position, and to prepare for a vigorous siege. The Jewish chief, however, waited not for the attack, but rushed fearlessly out upon the Roman camp, tore to pieces their outworks and entrenchments, and retreated in good order, without loss. The advance of the legions compelled the Jews to resort to their galleys, of which they had prepared a great number; these they drew up, at anchor, in line of battle, sufficiently near to the shore to maintain a fight of missiles with the enemy on land, while they were secure against the danger of being boarded.

In the meantime a large body of the inhabitants had marched out into the plain that was before the walls, and were forming for battle. Vespasian sent Titus with six hundred cavalry to disperse them; but the latter, finding the array more formidable than he had anticipated, sent for reinforcements. Four hundred more horsemen, under the command of Trajan, were accordingly forwarded to his aid; and at the same time a body of two thousand archers were stationed upon the brow of a hill that overlooked the wall, that they might sweep off the opposition 
from the battlements. The onslaught was now commenced by the Roman horse. Titus distinguished himself by many acts of daring valour: the Jews manfully maintained their ground for some time; but the impetus of the cavalry was irresistible, and the long lances which they carried gave them an advantage in the charge, which the half-armed multitude could not withstand; they were overborne, pierced through, and trampled under foot by the iron hoofs of the horses; at length they fled in confusion back to their gates, leaving many of their number dead upon the plain.

And now ensued a tumult within the city, caused by the contention of those who were disposed to submit with those who were determined to resist to the last extremity. The uproar reached the ears of the enemy without, and Titus, taking occasion to encourage his troops, led a few of the boldest down to the margin of the lake, and found means to enter the city. The panic, which the presence of the enemy within the walls produced, disarmed opposition; many of the insurgents, with Jesus their leader, escaped by the other gates, and dispersed over the country; some strove to get on board their ships by rushing down to the shore in the very teeth of the Roman hosts, in which attempt many were slain; and even the pacific inclinations of those whose counsels had been overborne in the city did not prevent their being indiscriminately put to the sword; until Titus, at length, finding the place in his possession, commanded the carnage to cease.

The next day Vespasian gave orders to pursue the 
fugitives, who, when they perceived that their city was taken, had pushed out towards the middle of the lake. He seized a number of the vessels which he found upon the shore, and having fitted them up with expedition, and manned them with his troops, dispatched them after the Taricheans. Probably the wind would not permit them to escape into the country around the north of the lake, or they were too few and unskilful to work the ships; the shore behind and around them was in the possession of the Roman troops, so that, though unarmed, they had nothing to do but await the onset of their enemies. Their vessels were small, weak, and ill-manned; but those which Vespasian had fitted out were strong, and filled with armed men. The only mode of annoying the Romans was by throwing stones at them from a distance, but these fell harmless from the helmets and coats of mail of the legionaries; whereas, if they ventured nearer, the Roman javelins transfixed them. The pursuers endeavoured to come into close contact with the fugitives, aiming to run them down, or striking them in the middle to break them through, or, if that failed, leaping on board, sword in hand, and slaying them; if the fugitives evaded the contact, so as to baffle the boarders, they were run through with the long pikes which the legionaries carried. No mercy was shown to the wounded or drowning; they were pierced as they struggled with the waves, or if they swam to the Roman ships, and supplicated for help, their heads were cleft or their lifted hands chopped off, in reply. At length, after most were destroyed, 
the shattered remnant were driven back to the shore they had left, environed by the pursuing squadron. Here they were hemmed in by land and sea; enemies, relentless as tigers, were round them on every side; and thus the poor Galileans were all slaughtered at leisure, like helpless sheep. The number of the slain in the siege and in this seafight (if fight it could be called) amounted to six thousand five hundred. The waters of the lake seemed as though they had been turned to blood, and the whole surface was strewn with fragments of wreck, and with swollen and discoloured corpses; while the numbers that were washed up on the shore, and that lay festering in the sun, so corrupted the air, as to produce alarm in the minds of the Romans themselves.

But, sickening as is the account of this dreadful slaughter, a more horrible transaction remains to be narrated;-one which affixes a lasting blot upon the memory of the Roman general. The proper inhabitants of the city had been all along friendly to the imperial authority, the war-party having consisted mainly of fugitives from other places, who had resorted to Taricheæ, especially after the reduction of Tiberias, on account of its naval position and means of defence. Vespasian called a council of war, to deliberate on the fate of these inhabitants, who had really done nothing offensive to the Roman majesty. He seemed at first inclined to spare them; but others advised that they should be slain, asserting that though, indeed, the pledge of his right hand had been given for their safety, he needed not to 
keep faith with Jews. Accordingly the general, acting with the most diabolical treachery, affected to give them their liberty, but commanded that they should leave the city only by the road that led to Tiberias. The poor unsuspecting people readily obeyed, and went along securely with their effects by the way which was permitted them, while the Romans took care to guard the outlets of the road on each side, and shut them up in the city. Then came Vespasian, and having assembled them in the stadium, ordered all the aged, together with the others that were "useless," to be slaughtered in his presence, to the number of twelve hundred. Six thousand of the able-bodied youth he sent to Nero, to be employed in a labour which he was then projecting,- the digging of a canal through the Isthmus of Corinth. Some he presented to Agrippa; and the remainder, amounting to thirty thousand four hundred, he sold for slaves.

Thus was unhappy Israel beginning to feel the bitterness of the wrath which came upon them in consequence of having rejected the meek and lowly One, who would have gathered them together and sheltered them with His love:- - the very doom was befalling them, in consequence of their denial of their lawful King and Lord, which they had feared as the result of believing on Him. The Romans were come and were taking away their place and nation! Nor was the pitiless character of their stern policy unpredicted. Long ago had Israel been warned of the fruits of disobedience; the picture of this very desolation, in all its minute reality of 
horror, had been drawn by the finger of God, and exhibited for their admonition and fear, fifteen hundred years before.

The LORD shall bring a nation against thee from far, from the end of the earth, as swift as the eagle flieth; a nation whose tongue thou shalt not understand: a nation of fierce countenance, which shall not regard the person of the old, nor show favour to the young: and he shall eat the fruit of thy cattle, and the fruit of thy land, until thou be destroyed: which also shall not leave thee either corn, wine, or oil, or the increase of thy kine, or flocks of thy sheep, until he have destroyed thee. And he shall besiege thee in all thy gates, until thy high and fenced walls come down, wherein thou trustedst, throughout all thy land: and he shall besiege thee in all thy gates throughout all thy land, which the Lord thy God hath given thee. Deut. xxviii. $49-52$.

The Roman progress in conquest had yet proceeded but slowly, for it was now about the beginning of September, and yet Galilee was not subdued. Three fortresses, undismayed by the fate of Jotapata and Taricheæ, still held out against the invader, Gamala, Gischala, and Mount Tabor. The first of these was a mountain fortress, situate not far from Taricheæ, but on the opposite side of the extremity of the lake. In natural strength it far exceeded even Jotapata, and was believed to be impregnable; being built on a lofty ridge, shaped somewhat like the back of a camel (pis, gamal), whence its name was derived. On each side, and in front; abrupt precipitous valleys of great depth divided it from the surrounding hills; but behind it was connected with the mountain range by a sort of neck or isthmus, and this was fortified by means of oblique trenches, which cut off all approach. The summit of the ridge was very steep, so that the houses, with which 
it was entirely covered, seemed to be built over each other, and appeared as if they were about to fall. The city faced the south, where it was of immense height; and here the precipice was a perpendicular cliff, so abruptly rising from the deep ravine beneath, that it needed no wall, or other defence. The presence of a fountain within the city was a circumstance of inestimable value to a garrison.

The natural strength of this place had been increased during the administration of Josephus by the erection of a strong wall, where defence was needful, as well as by the excavation of moats and subterranean passages. The garrison was not so strong as that of Jotapata had been, but their confidence in their impregnable position was unbounded; and, indeed, the city had already successfully held out against the forces with which Agrippa had besieged it for seven months.

Unwilling to leave behind him an enemy unsubdued, Vespasian sat down against this proud citadel of strength. It was impossible to encompass it with his army; he therefore disposed his force in three divisions, the fifth legion being posted opposite the middle of the city, the fifteenth on the mountain which overlooked it on the east, and the tenth being employed in filling up the trenches and levelling the approaches. The usual accompaniments of a siege followed; embankments were erected; the catapults cleared the battlements; and the battering-ram opened a breach in the wall. Thus ingress was with comparatively little difficulty afforded to the besiegers, notwithstanding the overweening confidence 
of the garrison. But now a singular reverse befel them. The inhabitants, with furious valour, fell upon the Romans in the narrow streets, and not only repelled the assault, but compelled the invaders to flee into the higher parts of the city. Here, however, they were quickly surrounded by the exasperated multitude, acquainted with every local advantage: being unable to fight in the steep and narrow lanes with eager antagonists above them and around them, they became greatly distressed: others of the army came forcing their way in at the breach, who rather impeded than helped their confused and depressed comrades. To escape, the legionaries began to take refuge in the houses of the citizens; but these, becoming full of armed men, were unable to bear the weight, and fell with a crash upon others beneath them. The manner in which they were built caused the fall of one house to be the ruin of many others, and thus a vast number of the Romans were destroyed, being crushed in the ruins, or suffocated by the clouds of dust that arose. At the same time they were so hemmed in and pressed that, although they saw the houses subsiding, they were compelled to leap upon the tops of them; while the inhabitants, observing this, became more strenuous in their exertions to force their enemies into the falling buildings. The very ruins themselves afforded ready weapons, in the stones and bricks of which they were composed, wherewith an active and elated populace might crush an enemy, bewildered and pent in amidst narrow streets, more especially as these streets were steep and rocky, and the 
enraged assailants had the higher position : the dust also blinded and choked the Romans, so that, not knowing where to tread, they perpetually stumbled and fell, while their opponents were familiar with every crag and corner, and, being above, were more out of the sphere of the dust.

Vespasian himself had well nigh finished his career amidst the ruins of Gamala, for he had gradually groped his way to the higher parts of the city, when at length he found himself almost alone, surrounded by perils. With great address, however, his little party slowly retreated, still keeping their faces towards their enemies, and made good their escape without the walls. But a great multitude of the soldiers perished in the city, comparatively few of those that had entered the breach being permitted to return ; and the dejection that fell upon the army, in consequence of so unprecedented a misfortune, was a still more serious evil than the actual loss of men.

It was some time before the Romans ventured again to the breach; and in the meanwhile Vespasian, to encourage their spirits, sent a body of troops, under the command of Placidus, to attempt the reduction of Mount Tabor. This is the highest mountain in that part of Galilee, and is the most singular and romantic in all Palestine. It is of a somewhat conical form, flat at the top, and stands alone, rising in solitary grandeur from the plain of Jezreel. A winding path leads to the summit, the magnificent view from which amply repays the traveller's labour in ascending it. The plain at the 
top is still surrounded by an ancient wall, which is probably the very same with which it was fortified at the period of which we are speaking. Josephus himself had erected this wall, and strengthened the little city that it encompassed in other ways, and furnished it with water and other necessaries for maintaining a siege.

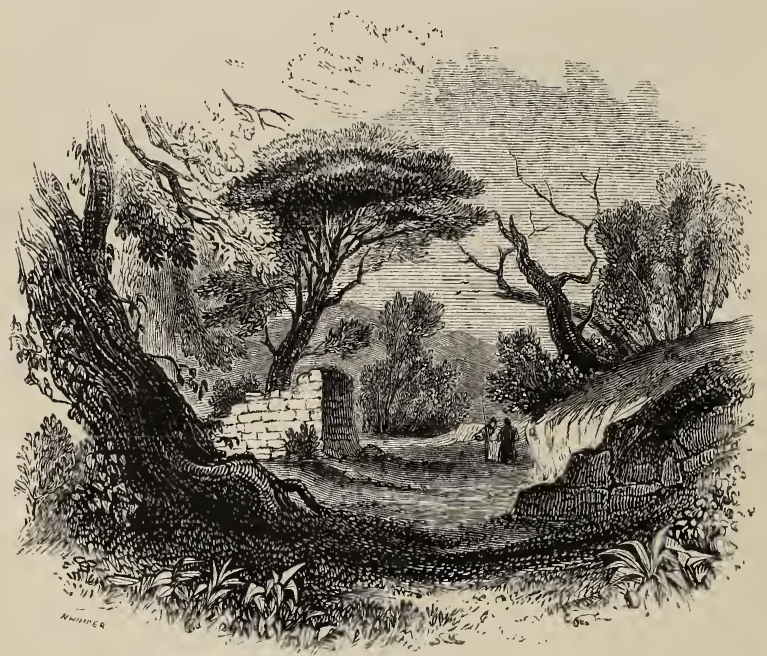

SUMMIT OF MOUNT TABOR.

The Roman tribune perceived that it was hopeless to attempt the capture of this stronghold by assault; he therefore attempted the milder arts of persuasion, with the design of drawing the garrison down into the plains. The Jews affected to yield to his solicitations, but were equally intent upon treachery. The Roman, however, outwitted the Jews, and, by prac- 
tising the old manœurre of pretending to flee, drew them out in pursuit over the plain, till there was good vantage-ground for the use of his cavalry; then suddenly turning upon them, he intercepted their retreat, and cut them to pieces. The remnant left in the fortress then came to terms, and submitted to the Romans.

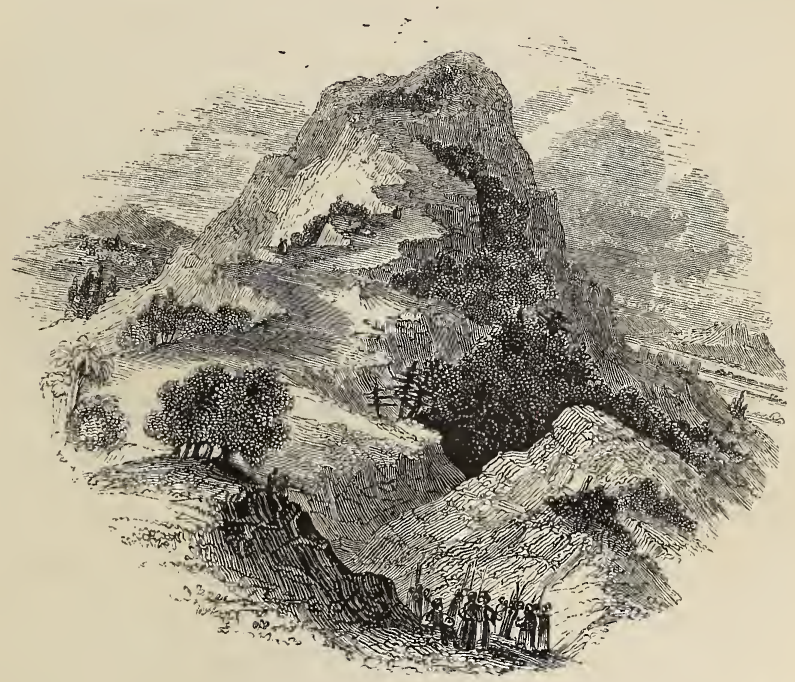

MIOUNT TABOR.

Meanwhile the garrison of Gamala maintained the siege, nor was it until the Roman army had encompassed it a whole month that it was taken. But at length three soldiers, working by night, contrived to undermine a high tower without discovery. Having dislodged five of its largest stones, they secured their own safety by a sudden flight, while 
the tower fell with a tremendous crash, burying its guard and many of the inhabitants in its ruins, and striking consternation through the city. A day elapsed, however, before the legions, rendered cautious by their former misfortunes, ventured to enter the walls; but on the 24th of Tisri (near the middle of October) Titus led his troops to the assault. A vigorous resistance awaited him, and a great number of the Romans were slain; but a terrific storm prevented the Jews from standing securely on their craggy heights, and, beating in their faces, annulled the effects of their arrows and darts, but assisted those of the enemy. The valour of the unhappy Gamalites availed them nothing, but increased the rage of their conquerors, already excited to savage fury by the recollection of their former defeat. They spared none : neither sex nor age moved their iron hearts to compassion; with pitiless ferocity they dashed down the tender infants from the citadel upon the crags and points of the ravines. Multitudes threw their own children and wives from the rocks, and then leaped after them, to avoid falling into the hands of those who knew not how to show mercy. Four thousand perished by the edge of the sword; but the number of mangled bodies found at the bottom of the precipices was even greater than this; nor was a single individual saved of the inhabitants of that ill-fated town but one man and his two daughters, who secreted themselves so as to avoid discovery.

The small town of Gischala was now the only fortress in Galilee that had not submitted to the 
Romans. Its resistance was not owing to the martial spirit of its proper inhabitants, for they were chiefly quiet husbandmen, but to the intrigues of John, the son of Levi, the rival and opponent of Josephus, who, with a band of resolute men, had thrown himself into the town, and defied the advancing army. Vespasian, however, thought a thousand horse, under the conduct of Titus, a sufficient force for the reduction of this place, and sent the army into winter-quarters; the tenth legion at Scythopolis, and the other two with himself at Cesarea. Nor was he deceived; for no sooner was Titus before the walls, than the redoubted John seized the cover of night to escape from the gates, and flee to Jerusalem, which he managed to reach before the troops sent to pursue him could come up with him. The city now opened its gates to Titus, who yet stained his laurels by the slaughter, in cold blood, of six thousand helpless women and children, who had endeavoured to flee with John, but had been unable to proceed.

A whole campaign had passed since the arrival of the Roman army and its veteran commander, and Galilee alone was subdued. That so small a province could have withstood the whole force of Rome so long, shows as well the indomitable valour of the Jewish people, as the natural strength of the country which they defended with their lives. For it is to be observed that the war was mainly a war of posts; no battle, of any importance, took place in the plains; the country was full of precipitous mountain ranges, the summits of which were studded with 
fortresses, rendered both by nature and art impregnable to any power short of the military skill, experience, and perseverance, of the iron legions of Rome. And it is interesting to notice that this peculiar character is assigned to this war in that prophetic description of it to which we have already referred, and shall again refer.

And he shall besiege thee in all thy gates, until thy high and fenced walls come down, wherein thou trustedst, throughout all thy land : and he shall besiege thee in all thy gates throughout all thy land, which the LORD thy God hath given thee. Deut. xxviii. 52 .

But now at length the work was done, and the silence of death reigned over that fair province, so lately alive with the hum of busy men. History dwells on the subjugation of those cities whose strength, importance, and pertinacious resistance impart interest to its narrative, and passes lightly over the desolation of rural districts, and the depopulation of unwalled villages. The trampling down of cultivated fields, the abduction of cattle, the sacking of mansions and villas, the burning of villages and hamlets, with the unimaginable horrors of rapine and massacre, which accompany the marches and counter-marches of an enraged soldiery, are but little noticed by the historian, though not less real a part of the sufferings of an invaded people, than the siege of cities and the slaughter of garrisons. He, who could have trod the shores of the beautiful Sea of Galilee at this time, would have found himself a solitary wanderer through a region which was lately full of inhabitants; the calm face of the lake was yet scarcely purged from 
the crimson stain which had recently dyed its waters, and the white sands of its shore were strewn with the whiter bones of men, from which the flesh and sinews had been picked by the beak of the vulture. The many fair towns, whose white turrets had recently gleamed in their beauty from the dark green groves that embowered them, or had been reflected

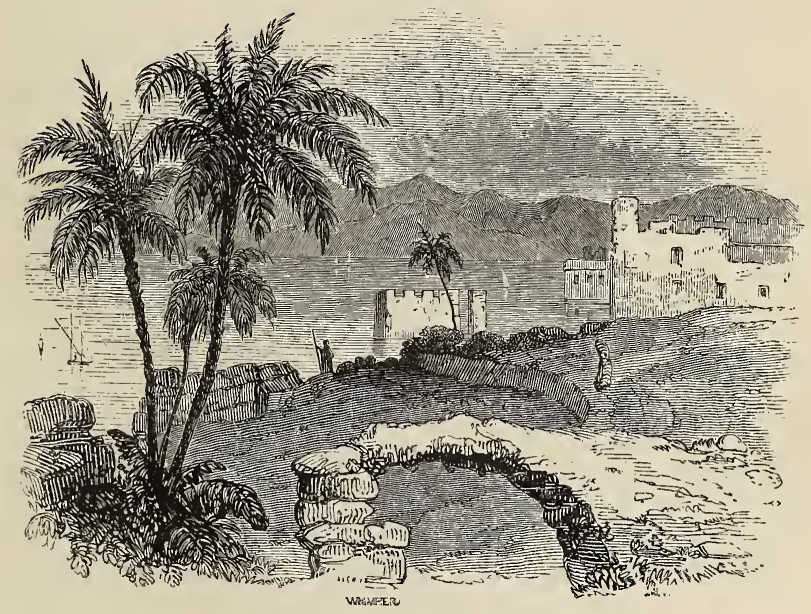

RUINED BATHS ON LAKE TIBERIAS.

in the mirror-like sea, were now heaps of blackened ruins, in which the embers were scarcely cold; and the chambers, where lately had sparkled the glancing lights of the peaceful eventide, now at the same hour sent back only the green gleam of the hyena's eye; and for the merry laugh of childhood's happy circle, resounded now only the shriek of the jackal. Capernaum, Chorazin, Bethsaida,-where were they? 
Lately the sound of mirth and jollity, the ringing of tabret and harp, the voice of the bridegroom and the bride, had filled their halls ; the songs of the fishers, as they drew their sweeping nets to shore, had enlivened the beach; and from their wharves had shot many a white-sailed pleasure-skiff, filled with youths and maidens, in whose light hearts remained no memory of Him, who a little before had dwelt among them, "full of grace and truth." His accents of mercy, His tender and touching appeals, and even His mighty signs and wonders, had long been forgotten, and no wonder that His solemn warnings of sure and certain judgment had been forgotten too. But they had been uttered by a tongue that could not lie; and they were written in the Book of Him whose "word is truth," and they yet remain for our admonition and instruction, "upon whom the ends of the world are come."

Woe unto thee, Chorazin! woe unto thee, Bethsaida! for if the mighty works had been done in Tyre and Sidon which have been done in you, they had a great while ago repented, sitting in sackcloth and ashes. But it shall be more tolerable for Tyre and Sidon at the judgment than for you. And thou, Capernaum, which art exalted to heaven, shalt be thrust down to hell. Luke x. 13-15.

And now the doom was fallen; the judgment was come upon the guilty cities; and they who had despised the mercy of the Son of God, when brought to their very doors, had now sought it and found it not. Surely some among them must have thought of the awful words of their own Scriptures, when the inevitable desolation fell upon them, smiting root and branch! 
Because I have called, and ye refused ; I have stretched out my hand, and no man regarded; but ye have set at nought all my counsel, and would none of my reproof; I also will laugh at your calamity; I will mock when your fear cometh. When your fear cometh as desolation, and your destruction cometh as a whirlwind; when distress and anguish cometh upon you. Then shall they call upon me, but I will not answer; they shall seek me early, but they shall not find me: for that they hated knowledge, and did not choose the fear of the Lord: they would none of my counsel ; they despised all my reproof : therefore shall they eat of the fruit of their own way, and be filled with their own devices. Prov. i. $24-31$.

It is interesting to inquire what is the present condition of the scenes which witnessed so terrible a calamity. From that stroke they have never recovered. Nature puts forth all her beauty there as before; the lake is as lovely, the banks as verdant as ever they were; the beams of as bright a sun still play on waters as blue and sparkling: but silence and desolation reign over all.

One of the best descriptions by modern travellers of the Lake of Gennesaret is that of Dr. Clarke, who saw it, indeed, from the most favourable point of view for discerning its loveliness, the summit of the hill commonly called the Mount of Beatitudes. "From this point," says the Doctor, "a view was presented, which, for its grandeur, independently of the interest excited by the different objects contained in it, has nothing equal to it in the Holy Land.

"From this situation we perceived that the plain over which we had been so long riding [from the west] was itself very elevated. Far beneath appeared other plains, one lower than the other, in a regular gradation, reaching eastward, as far as the surface of the Sea of Tiberias. This immense lake, almost 
equal, in the grandeur of its appearance, to that of Geneva, spreads its waters over all the lower territory. Its eastern shores exhibit a sublime scene of mountains towards the north and south, and they seem to close in at either extremity, both towards Chorazin, where the Jordan enters, and the Aulon or Campus Magnus, through which this river flows into the Dead Sea. The cultivated plains reaching to its

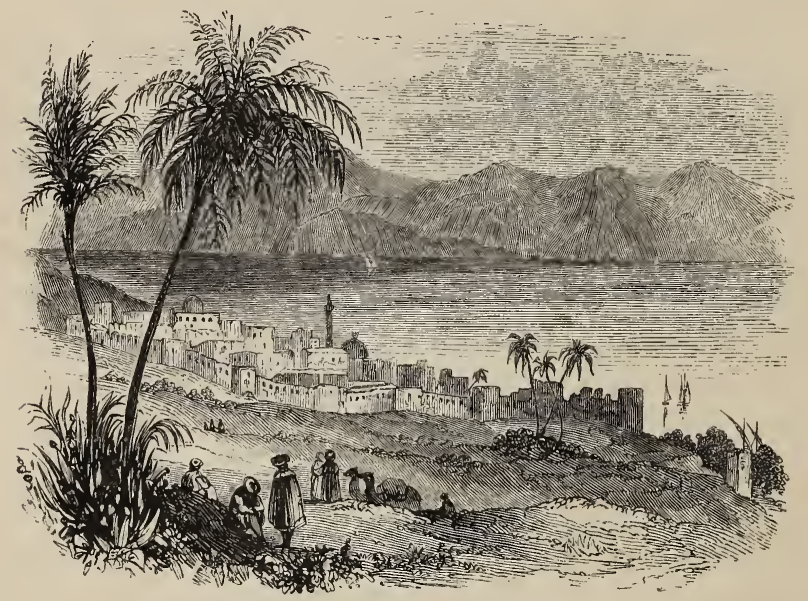

LAKE OF TIBERIAS.

borders, which we beheld at an amazing depth below our view, resembled, by the different hues their various produce presented, the motley pattern of a vast carpet. To the north appeared many snowy summits, towering beyond a series of intervening mountains. We considered them as the summits of Libanus; but the Arabs belonging to our caravan called the principal eminence Jebel-el-Sieh. The 
summit was so lofty that the snow entirely covered the upper part of it, investing all the higher part with that perfect white and smooth velvet-like appearance, which snow only exhibits when it is very deep."

Continuing his way over the plain, before reaching the edge of the steep declivity which conducts down to the shore, the same traveller writes :- "The lake continued in view to our left. The wind rendered its surface rough, and called to mind the situation of our Saviour's disciples, when, in one of the small vessels which traversed these waters, they were tossed in a storm, and saw Jesus, in the fourth watch of the night, walking to them upon the waves. Often as the subject has been painted, which combines a number of circumstances favourable to a sublime representation, no artist has been aware of the uncommon grandeur of the scenery memorable for the transaction. The Lake of Gennesareth is surrounded by objects well calculated to heighten the solemn impression made by such a picture; and, independently of the local feelings likely to be excited in its contemplation, it affords one of the most striking prospects in the Holy Land. It is by comparison alone that any due conception of its appearance can be communicated to the minds of those who have not seen it. Speaking of it comparatively, it may be described as longer and finer than any of our Cumberland and Westmoreland lakes, although it be, perhaps, inferior to Loch Lomond in Scotland. It does not possess the vastness of the Lake of Geneva, although it much resembles it in certain points of view. In picturesque beauty it perhaps comes nearest 
to the Lake of Locarno in Italy, although it be destitute of anything similar to the islands by which that majestic piece of water is adorned. It is inferior in magnitude, and perhaps, in the height of the neighbouring mountains, to the Lake Asphaltites; but its broad and extended surface, covering the bottom of a profound valley, surrounded by lofty and precipitous eminences, when added to the impression under which every Christian pilgrim approaches it, gives it a character of unparalleled dignity."*

Commenting on this description, Dr. Kitto makes the following observations :-

"From lower points of view, on the descent to the lake, and from the plain by which the lake is bordered, much of all this grandeur is lost; and much that looks beautiful in the distance becomes bald and barren in the nearer view. That nearer view is still grand, especially from the plain at the northern extremity of the lake. On the east rise the mountains, not precipitously, but rolling back from the shore, green and verdant after rain, but destitute of trees. On the west, hill rises above hill in beautiful succession, and the loftiest visible summit is crowned with a city whose commanding position $\psi$ is probably unequalled in the world. In two places the mountains here come down to the lake; the rest is a beautiful and uncultivated plain-that rich and fertile ' land of Gennesareth, which, for its combinations of natural advantages, soil, scenery, climate, temperature,

* Travels, part ii.

+ Safet ; supposed to be the "city set upon a hill, which cannot be hid." 
is, perhaps, exceeded by no other spot on earth. In winter and spring this plain is traversed by numerous torrents, some of which are so large and rapid as not to be passed without difficulty. 'Nothing can surpass the beauty and grandeur of the surrounding scenery,' says Elliot, and he had travelled widely.

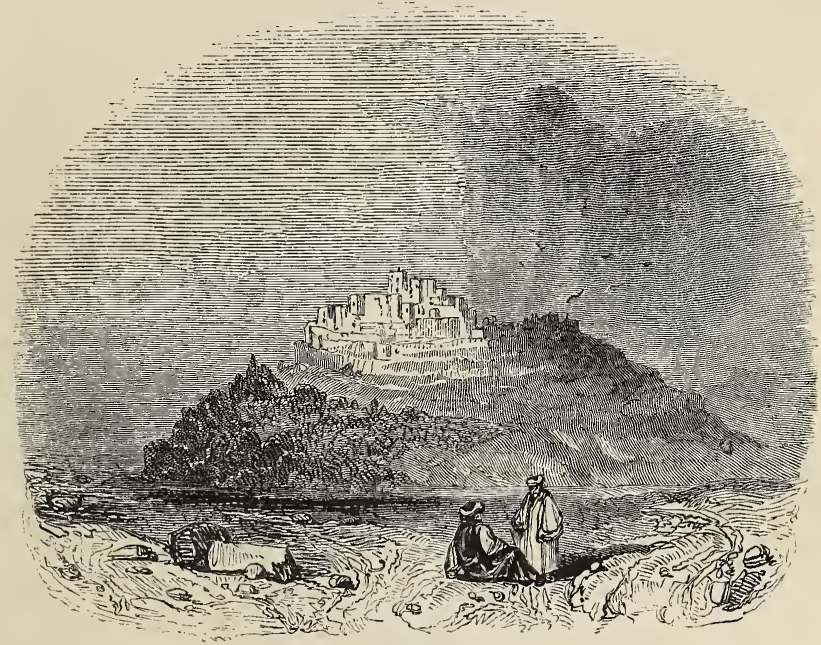

SAFET.

"The feathered tribes seem to make the lake a favourite resort. Multitudes of song-birds harbour in the northernmost groves, and their innumerable happy voices mingle with the rush of waters, where the river hastens to the lake. The margin and surface of the lake itself presents large flocks of storks, wild-ducks, and diving-birds ; pelicans are not wanting; while here and there vultures are assiduously engaged with their carrion-prey; or eagles, heavily 
flapping their broad wings, rise to their aëries in the mountains. But when the heat of the summer-sun -intensely concentrated on the borders of this deep basin-has absorbed all the moisture which the earth contained, and utterly dried up the green herbage which gave a cheerful aspect to the scene, the effect of the whole, in the entire absence of trees, is very different,-more dull, heavy, sad, but not less, perhaps, in unison with the general tone of feeling with which the Christian pilgrim is prepared to regard this memorable lake. Its surface is usually in a state of dead calm; and, in the universal stillness, the gentle plash of its water upon the pebbles of the shore is distinctly heard, and is, indeed, almost the only sound that strikes the ear. Not a single boat of any kind is seen upon the lake; and, now that the Arab has removed his tents to the higher country, the eye may wander around its borders in vain, seeking for any other signs of habitation than the mean town of Tabaria, and one or two miserable villages. The saddened traveller may gaze for hours over the scene without observing a single human being, or indeed any living creature, save the large waterfowl, whose sole presence tends rather to increase than to diminish the desolation of the view." *

* Physical Hist. of Palestine. 


\section{CHAPTER IV.}

THE ZEALOTS.

A. D. 67,68 .

The arrival of John of Gischala at Jerusalem had a depressing influence on the hopes of the insurgent citizens. That subtle chief would fain have persuaded them that he came with his adherents voluntarily to devote his talents and his blood to the defence of their city and temple; but the appearance of his breathless host, and the tales of terror which escaped, soon revealed the sad truth, that they had fled before a victorious enemy, and that the strong frontier province lay bleeding and bound beneath the foot of the Roman. The spirit of faction had been long brooding in Jerusalem; but the presence of this unprincipled, but able man caused it to break out into that dreadful strife, which continued to rage with suicidal pertinacity until the end, and marked the last days of this unhappy city with horrors unexampled in history. Inflamed by his exhortations, the young and bold became more vehement than ever, while the old and timorous saw, in the fate of Galilee, the utter hopelessness of the Jewish cause. Thus party strife, growing daily more stern and deadly, divided not only the national councils, but entered into every house ; and bursting 
all the bonds of kindred and friendship, made every family a scene of bitter, and often bloody, contention. Nor was this spirit confined to the metropolis; every city and village yet unsubdued was rent in the same manner; and the brand of mutual animosity seemed more cruel than the sword of the Roman. Bands of desperate villains spread themselves over the country, wasting it with fire and sword and committing the greatest enormities, under pretence of chastising those who favoured the invaders. At length a great multitude of these banditti crept, by stealth, into Jerusalem, and formed a powerful and daring faction, which proceeded from one enormity to another, until they began to murder, in open day, the most eminent persons in the city.

But as if this tyranny were not enough, the Zealots, as these robbers were called, proceeded to trample upon the dearest and most sacred of the national institutions, - that of the Priesthood. None but the sons of Aaron were eligible to this holy office; but these wretches took upon themselves to appoint the High-Priests out of the meanest and most degraded families, and to depose them at pleasure; until at length they placed in this high dignity a poor rustic, so ignorant and clownish that his rude awkwardness in his habiliments made his appearance the signal for jeers and laughter.

Such an affront upon public decency roused the indignation of the populace, which was inflamed also by harangues from Ananus, the chief of the Aaronic priests; and they eagerly demanded to be led on against the formidable faction which was so tyran- 
nizing over them. Ananus accordingly endeavoured to bring the vast and tumultuous body of the people into some sort of organization; for the Zealots were numerous, daring, well armed, and accustomed to fighting. And now began a terrific civil war, which furiously raged in the lanes and streets of the city, regardless of the common enemy that was approaching from without. After a while the Zealots, overpowered by superior numbers, retreated into the Temple, whose sacred floors were deluged with blood. The party of the High-Priest-did not think proper to press their victory beyond the Court of the Gentiles, but contented themselves with setting a strong and well-armed guard over the enemy, who had entrenched themselves in the Inner Court. The wily John of Gischala openly favoured the popular cause, and, being forward in counsel, was deputed to treat with the Zealots; but, with the deepest treachery, he had been holding secret communications with the latter, and now exhorted them to call in aid from an external source.

A hasty message was accordingly sent to the Idumeans, who now occupied the southern part of Judea, appealing to them for deliverance against Ananus, whom it charged with a design to betray the liberties of the city and nation to the Romans. The warlike temper of the Idumeans made this application very agreeable to them, and an army of twenty thousand, raised in an incredibly short time, proceeded, by forced marches, to the walls of Jerusalem. There, however, they found the gates shut against them; nor could they obtain entrance till the 
Zealots, taking advantage of a dreadful storm of thunder and rain by night, opened the doors of the Temple unperceived, and, stealing down to the citygate, admitted their allies.

The besieging party now suddenly found themselves besieged, and, being placed between two hostile armies, began to despair of life. The habitual ferocity of the Idumeans was increased to fury by the delay and exposure to which they had been subjected beneath the walls, and they showed no mercy. The howls of furious men, and the shrieks of terrified women, mingled with the fierce blasts of the wind and the roaring of the thunder on that fearful night. The battle swayed to and fro around and within the Temple; and the break of day revealed eight thousand five hundred corpses bathed in their own blood on the sacred pavement. Ananus himself lay among the slain; and his body, after being subjected to the utmost indignity, was cast out, unburied, to the dogs and vultures.

Thus fell a man who might, humanly speaking, have restored peace to the nation by the wisdom and moderation of his counsels. The grandeur of his rank and office, and the nobility of his descent, were jllustrated by his personal character. He had maintained a spotless reputation for justice and honour in those degenerate times; he was affable and benignant in his manners, and disinterested in his policy, preferring the welfare of the people to his own advantage. He was a strenuous advocate for peace and submission to the Romans; and having already, by his influence with the people, acquired a decided 
superiority over the war-party, he might, but for the treachery of John, have yet obtained honourable terms of peace from Vespasian. But the irrevocable doom had gone forth from the Most High, and who could disannul it?

An unresisted massacre followed this night of blood; the populace being hewn down in the streets, and those of higher rank, after cruel scourgings and tortures to induce them to change their politics, being slain in the prisons : twelve thousand "of the better sort" perished in this manner. There was one person whose murder calls for particular notice. Zacharias, son of Baruch, one of the most eminent of the citizens for wealth and honours, had made himself obnoxious to the Zealots by his probity and his testimony against their wickedness. Him they determined to get rid of: so, summoning a sort of Sanhedrim, consisting of seventy of their own creatures, they accused him of partiality to the Romans. Not a shadow of proof could be adduced of his criminality; but instead of defending himself, or appealing for mercy, the righteous man pressed home upon the consciences of his accusers their transgression of the law of God, and the miseries they had brought upon the nation. His faithful testimony, as in the case of Stephen before, so infuriated them that, in a tumultuous manner, they clamoured for a verdict: but so clear was the innocence of the prisoner, that the pseudo-judges brought him in guiltless; when two of the most daring of the Zealots rushed upon him with their swords, and slew him, with insult, "in the middle of the Tern. 
ple," after which they cast out his body into the Valley of Jehoshaphat.

From the names of this worthy man and his father, the place and circumstances of his death, and his virtuous character, some have supposed, not without reason, that this may have been the Zacharias, the son of Barachias, whose death was alluded to by the Lord, as closing the list of martyrs whose blood should be avenged upon guilty Jerusalem. And there certainly seems more probability that the martyr so spoken of should be one slain in the last days of the city, than one who lived so long before as the prophet of the same name, of whose death we have no record, especially as we know that there was a deluge of righteous blood shed in Jerusalem after our blessed Lord's utterance of those solemn words.

Wherefore, behold, I send unto you prophets, and wise men, and scribes : and some of them ye shall kill and crucify : and some of them shall ye scourge in your synagogues, and persecute them from city to city: that upon you may come all the righteous blood shed upon the earth, from the blood of righteous Abel unto the blood of Zacharias son of Barachias, whom ye slew between the temple and the altar. Verily I say unto you, All these things shall come upon this generation. Matt. xxiii. $34-36$.

At length the Idumeans grew weary of slaughter, and began to feel indignant at the position into which they had been betrayed; for having been artfully induced to come as national deliverers, they found themselves mere butchers of citizens. Having therefore first opened the gaols, and liberated about two thousand prisoners, they returned to their own province, leaving the populace and the Zealots alike 
in joy at their departure; the former congratulating themselves on being freed from powerful persecutors, the latter that they should now be able to prosecute their iniquitous designs without any check from these their less abandoned associates.

A sevenfold spirit of demoniacal madness now reigned in the doomed city; and the picture drawn of Jerusalem by the Jewish historian forms a vivid comment on the awful words in which the Lord Jesus had predicted the abandonment of the City of Holiness to "the unclean spirit."

When the unclean spirit is gone out of a man, he walketh through dry places, seeking rest, and findeth none. Then he saith, I will return into my house from whence I came out; and when he is come, he findeth it empty, swept, and garnished. Then goeth he, and taketh with himself seven other spirits more wicked than himself, and they enter in and dwell there: and the last state of that man is worse than the first. Even so shall it be also unto this wicked generation. Matt. xii. 43-45.

The Zealots now threw off all restraint: the eminence of any man, whether for virtue, station, or wealth, was the signal for his destruction; the good they murdered from hatred, the noble from fear, the rich from covetousness. No wariness of conduct was a security; if one did not come near them at all, he fell under their suspicion as a proud man; if any one came confidently, he was esteemed a despiser of their power; and if any professed a wish to serve or oblige them, he was suspected of treachery; accusation was equivalent to condemnation, and there was but one punishment for all sorts of crime, DEATH. Multitudes fled from the city, though to be detected in desertion was fatal, and the gates were strictly 
guarded; but many of those who escaped, returned to die within the precincts of the Holy City, from the horror of remaining unburied. But their hopes were vain; for the ceremony of interment was now denied even to those dying within the city; and, as if the last feelings of nature were to be violated by these wretches, it was made a capital crime to give the shelter of a grave to a departed friend. The high roads, the fields, and the villages, were strewn with dead bodies in vast numbers, corrupting in the sun; the flocks of obscene vultures, that sat lazily on the fences and house-tops, were utterly insufficient to consume the corpses; while the heaps of unburied slain that lay in the streets of Jerusalem already threatened a pestilence. The demons in human form, who ruled with a rod of iron this ill-fated city, trampled under foot the laws of man, and laughed at the law of God; they affected to ridicule, as juggling impostures, the solemn predictions of the Prophets, which they were madly accomplishing.

Without the city desolation was working its way no less surely. The band of robbers that had taken possession of the strong fortress of Masada, known by the name of Sicarii, or Men of the Poniard, were engaged in wasting the country with fire and sword, massacring the population of the villages, and carrying their plunder into the fortress. The impunity of these wretches emboldened others to band together for a like purpose; and thus was the whole face of the country infested with increasing hordes of these desperate men; and the Daughter 
of Zion was stabbed to the heart, not only by the sword of the Roman, but by the daggers of her own unnatural children, far more cruel than the idolatrous Grentiles themselves.

How hath the Lord covered the Daughter of Zion with a clond in his anger, and cast down from heaven unto the earth the beauty of Israel, and remembered not his footstool in the day of his anger! Lam. ii. 1.

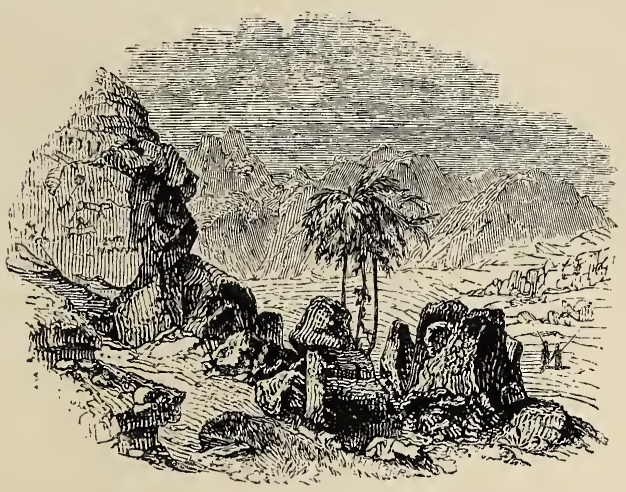




\section{CHAPTER V.}

THE RESPITE.

\section{A.D. 68,69 .}

THE winter and spring of the year 68 were occupied by the Romans in the subjugation of Perea and Idumea. The former, known in Scripture as "the country beyond Jordan," was soon reduced by the tribune Placidus; who, having advanced against Gadara, the chief city, and taken it by capitulation, overran the whole region with his troops. A strenuous resistance was made at Bethanabris, a walled town near the Jordan, perhaps the same with "Bethabara, where John was baptizing." A number of fugitives from Gadara had reinforced the garrison of this place, who, on the approach of Placidus, sallied forth to give him battle. The old stratagem of a feigned flight drew the Jews from the walls into the plains, when, their retreat being suddenly cut off by the cavalry, they were overborne and put to the sword, with the exception of a few, who fought their way through, and regained the walls. But here a dire necessity prohibited the garrison within from admitting them, for the Roman troops were close at their heels, and to admit the one would be to admit the other. They were therefore abandoned to their fate. 
But the closing of the gates was of little avail; for after a severe assault the walls were forced, and the inhabitants, as usual, were slaughtered without mercy. The fate of this place so terrified the surrounding country, that the inhabitants of the villages endeavoured to flee for their lives, and, getting together in

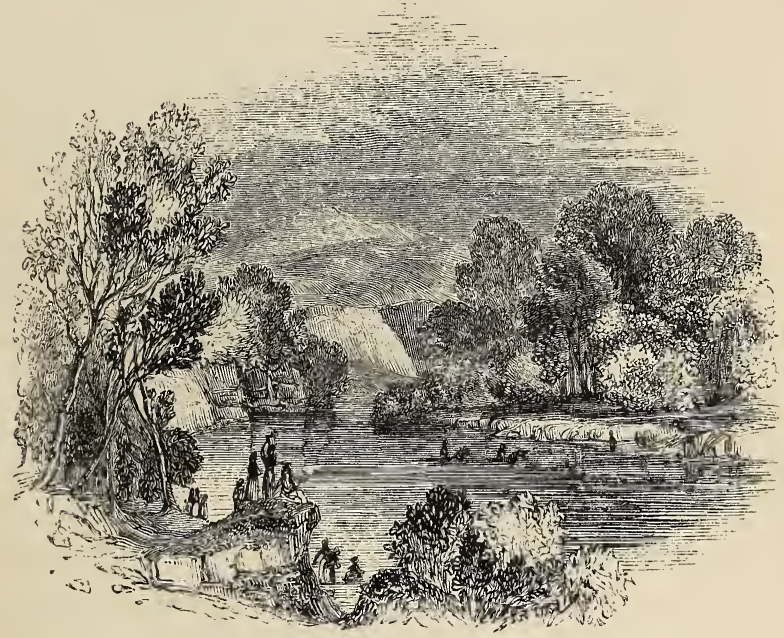

FORDS OF JORDAN.

great numbers, fled towards the Jordan, hoping to be able to reach Jericho, a strong city on the other side.

Placidus followed in their rear, hewing them down with his cavalry as they fled; and when they came to the river they found, to their utter dismay, that it could not be forded, for the winter rains had augmented the stream, and the current was both deep and rapid. It was the very spot where, of old, 
their fathers had passed over dryshod, the waters dividing before the divinely-guided tribes.

And it came to pass, when the people removed from their tents, to pass over Jordan, and the priests bearing the ark of the covenant before the people ; and as they that bare the ark were come unto Jordan, and the feet of the priests that bare the ark were dipped in the brim of the water, (for Jordan overfloweth all his banks all the time of harvest,) that the waters which came down from above stood and rose up upon an heap very far from the city Adam, that is beside Zaretan : and those that came down toward the sea of the plain, even the salt sea, failed, and were cut off: and the people passed over right against Jericho. And the priests that bare the ark of the covenant of the LonD stood firm on dry ground in the midst of Jordan, and all the Israelites passed over on dry ground, until all the people were passed clean over Jordan. Jos. iii. 14-17.

But now no miraculous interposition saved the trembling crowds, who, like frighted sheep, flocked to the banks. Behind them pressed the Roman horse, and the shrieks and groans of the dying told that the Roman sword was doing its bloody work fast and fatally. Before them was the Jordan, rolling on his swollen and turbid waters in many a whirling eddy to the Dead Sea. There was but a choice of deaths. Fifteen thousand gave their blood to the sword, while the number of those who were forced into the current was prodigious. The Dead Sea was covered (to use the words of the historian) with the floating corpses. After this dreadful calamity the rest of Perea soon submitted to the conquerors.

While Placidus was thus engaged in reducing the country to the east of the Jordan, Vespasian himself had turned his attention to the south of Judea. Intelligence of a revolt in Gaul, which threatened serious consequences to the Empire, induced him 
to hasten his operations, and to begin the campaign even before winter was over. Marching from Cæsarea to Antipatris, and thence to Thamnos, Lydda, and Jamnia, laying waste every town and village that offered resistance, and garrisoning the walled cities, he came to Emmaus. Here was an important pass

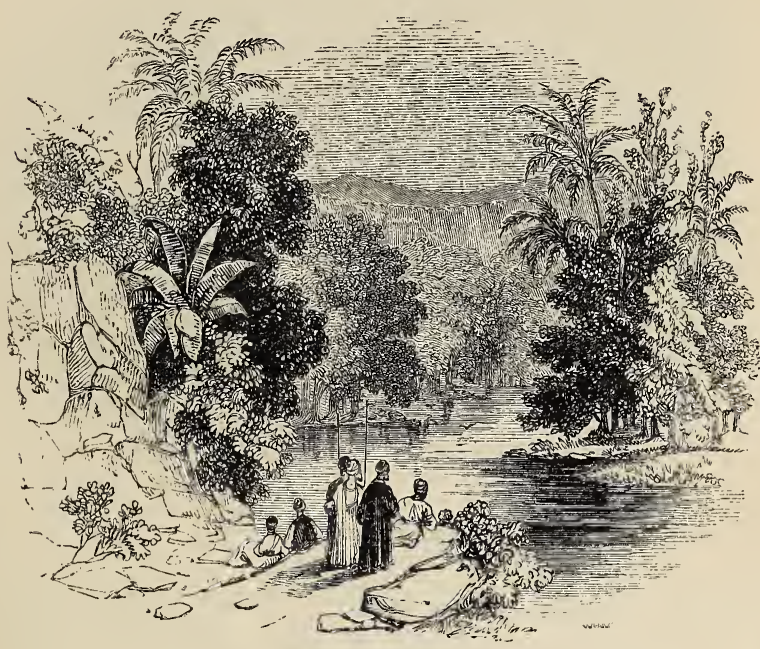

THF JORDAN.

that led to Jerusalem, to guard which the Roman commander thought proper to leave the fifth legion, while he continued his march southward into the very midst of Idumea. Having subdued this warlike province with much slaughter, and having overrun and laid waste the whole of " the hill country," and regarrisoned the fortresses, he returned to Emmaus. Thence, without delay, he traversed Samaria, and pitched his camp near the city of Sychar or 
Shechem, on the second day of the month Sivan, probably near the middle of May.

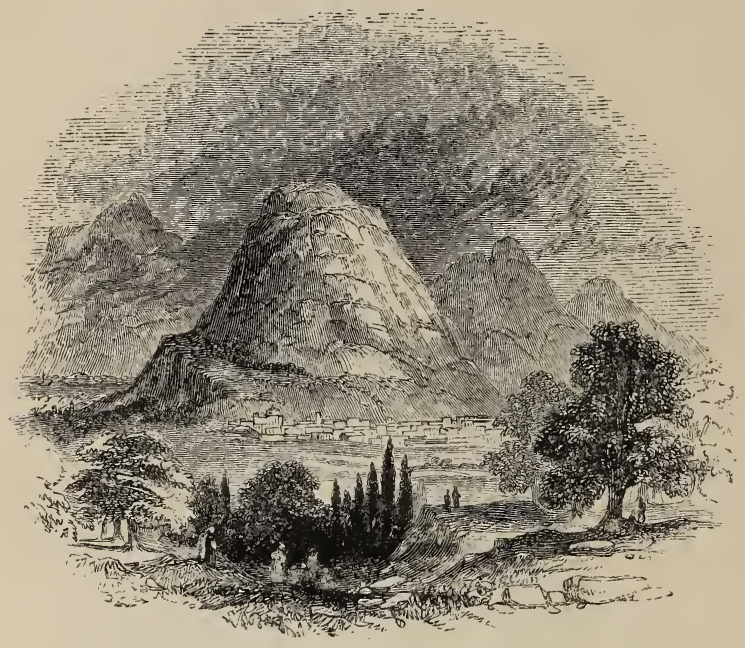

SHECHEN.

Thence, again turning south, Vespasian proceeded to Jericho, being joined on the way by the troops which had been occupied in reducing Perea. The city was found deserted; the inhabitants having fled at the approach of the Roman army, to seek a precarious refuge in the rocky mountains that surround Jerusalem.

The beautiful and ancient city of Jericho was situated in the midst of a vast plain, from the bosom of which rose a solitary mountain in naked grandeur. It was irrigated by a fountain, whose waters, after having been healed by the prophet 
Elisha, were a source of abundant fertility to this magnificent plain. At the time of which we write it was one of the most delightful tracts in the

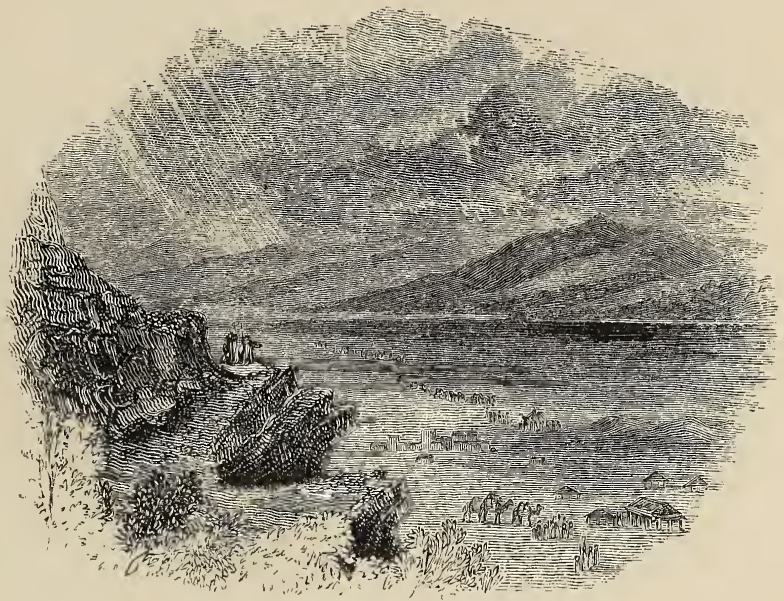

FLAINS OF JERICHO.

whole land of Judea. Josephus speaks of it with rapture, as possessing a loveliness almost divine; as abounding in productive gardens, embowered in shady groves; as ornamented with clumps of waving palm-trees of various species, prized both for beauty and for fruit; as singularly rich in other vegetable productions, valuable balms, and balsams; and as abounding in the honey of bees. The common fruits and grains of the country were here produced in profusion, for the soil was of uncommon fertility, and the climate was delightful, particularly in winter. 
In this beautiful and well-watered plain Vespasian seems to have remained for some months, regaling his soldiers after the toils of their devastating course,

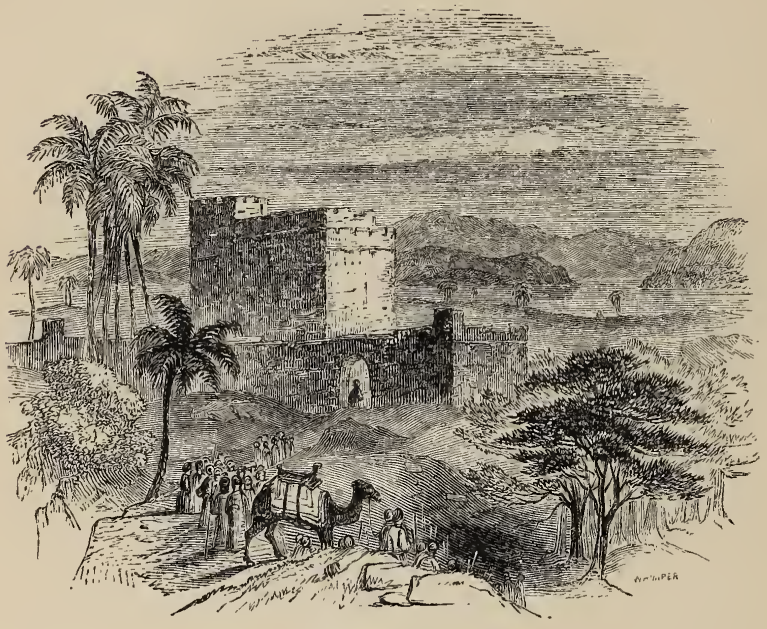

JERICHO AND THE JORDAN.

and recruiting their strength for the approaching assault upon Jerusalem. At length he returned to Cæsarea; but scarcely had he arrived there, and begun his preparations for the final march upon the capital, when intelligence of the death of Nero caused him to pause, and suspended the falling blow for nearly two years.

But Jerusalem knew not how to profit by this respite. The horrors of civil war raged there without any abatement of violence, and without intermission. The subtle John of Gischala had succeeded in dividing the faction of the Zealots into two hos- 
tile parties, of one of which he made himself the head; and these were perpetually engaged in mutual conflict, or rivalled each other in the perpetration of all enormities upon the wretched inhabitants. But now there arose another faction, as violent and cruel as either. Simon, the son of Gioras, who had distinguished himself in the rout of Cestius, a man of ferocious courage and determined spirit, had gathered a party of robbers, with whom he had wasted the country between Jerusalem and the Dead Sea. Gradually gaining strength and wealth by the reputation of his deeds, he at length found himself at the head of forty thousand daring men, well armed, besides twice as many followers. Having conquered and ravaged Idumea, he made no secret of his intentions to assault Jerusalem; and, though the warlike Zealots sent forth bands to form ambushes for him in the passes, they could not offer any serious obstacle to his triumphant progress, and at length he encompassed the city with his army. Here he raged like a wild beast, killing with horrible tortures all the unhappy individuals that ventured from the gates, and scarcely abstaining from tearing their flesh with his teeth. And thus was Jerusalem wasted by two armies within, and one without her walls, of her own children; so that the Romans could well afford to remain passive spectators of those who, with blind infatuation, were performing the work which they themselves had come to do.

Meanwhile the dreadful tyranny of John's faction had arrived at such a pitch, and so enormous was the unmentionable wickedness daily perpetrated by 
them in the city, that the people were driven to madness. At a consultation, in which the highpriests took part, as to what remedy could be devised, a resolution was adopted to admit Simon into the city to chastise John. Insane determination! as if they, who found the presence of one tyrant a burden too grievous to be borne, should be relieved by the addition of another! Even the half-heathen Josephus cannot avoid the reflection, that surely God in anger had "turned their counsels into foolishness."

It was about the time of the vernal equinox, in the year 69, that Simon, with no little ostentation and arrogance, took up his quarters in the city. The superiority of his forces enabled him to besiege John, who, with his Zealots, had entrenched himself in the Temple, from the cloisters and battlements of which, as from a strong fortress, the missile weapons of the besieged faction did great execution upon their enemies; the advantage of situation in some degree equalizing the conditions of the combatants.

About this time Vespasian was raised to the Imperial throne by the suffrages of the army; and, having disposed of such business as was urgent in Cæsarea, he proceeded with his son Titus to Antioch in the course of the autumn, and thence, by way of Alexandria, to Rome, where he assumed the purple amidst the most extravagant manifestations of popular joy. 


\section{CHAPTER VI.}

THE LAST WINTER OF JERUSALEM.

\section{A.D. 70 .}

"How is the faithful city become an harlot! it was full of judgment; righteousness lodged in it, but now murderers." The holy and beautiful house, which had been designed to be a house of prayer for all nations, was now full of armed men, raging for each other's blood, and shedding it like water upon the sacred pavements of polished marble. The doomed city, once "the perfection of beauty, the joy of the whole earth," was approaching the last agonies; and like a patient whose fevered blood has produced a horrible delirium, or rather like one of those unhappy beings whose body was possessed by a legion of unclean and malignant demons, lay tearing and devouring her own flesh.

Eleazar, with a small but determined band of Zealots, had seized the inner court of the Temple, where he fortified himself against John, who, with a larger body, possessed the outer courts of the same sacred edifice. $\mathrm{He}$ in his turn was beset by Simon, who had taken possession of the whole of the upper city and a great part of the lower. The stores of provisions which were laid up in the 
Temple were freely used by Eleazar and his party, who were imprisoned in this sacred fortress, while John and Simon alike supported themselves upon the plunder of the city. Granaries full of corn, and warehouses of other necessaries, were wantonly burned by each party, so that a provision which would have supplied the wants of the garrison and inhabitants for several years, was madly destroyed, as if on purpose to please the besiegers. Fierce and bloody were the conflicts which every day raged in the sacred precincts; the adherents of Eleazar, from the lofty fastnesses and battlements of the inner court, poured down their darts and arrows upon John, or rushed out in furious sallies; but the latter were sure to be repulsed by superior numbers, while the former were in some measure answered by the balistæ, catapults, and scorpions, which John had erected to hurl stones and darts against the battlements, and which made up for the inferiority of his position. But Simon was pressing him in like manner from behind; where, however, the circumstances of position were as much in his favour, as on Eleazar's side they were against him. The ascents of the Temple were steep and difficult, and a large number of assailants could easily be kept at bay by a few above their heads.

Amidst this furious warfare the ministrations of religion went on as usual ; and it was a strange thing to behold the Priests and Levites engaged in offering the Daily Sacrifice in the very midst of the din of battle, and the people crowding in to worship in the holy courts, while the arrows were hurtling around 
their heads; and ever and anon the roaring stones from the powerful engines would rush in among the prostrate worshippers, crushing them at the foot of the altar, and mingling their blood with that of the sacrifice. Priests and Zealots, worshippers and soldiers, citizens and strangers, fell in mingled heaps around the altar, and pools of human blood lay curdling in the midst of the sacred courts. The frequent sallies, and vehement conflicts with flame and sword, had cleared a large space around the Temple-walls, and reduced it to a blackened and desert area, in which the rival factions could fight the more furiously, because more unimpeded.

O Jerusalem, Jerusalem, thou that killest the prophets, and stonest them which are sent unto thee, how often would I have gathered thy children together, even as a hen gathereth her chickens under her wings, and ye would not! Behold your house is left unto you desolate. Matt. xxiii. $37,38$.

Such was the condition of "the City of the Great King," when there came against her the "nation of fierce countenance," and around her gathered in grim array the beleaguering hosts of Rome.

Early in the spring of the year 70, Titus had returned from Egypt to Cæsarea, and now led on his army to the siege of Jerusalem. The twelfth legion, which had been defeated under Cestius, was now added to the three which had been commanded by Vespasian; and there had arrived large reinforcements from the allied kingdoms. Through Samaria the mighty and glittering host wended its stately way, and at length encamped at Gibeah of Saul, about four miles to the north of Jerusalem. 
Here, leaving the army to pitch their temporary camp, the Roman general with six hundred chosen horsemen, pushed forward to reconnoitre the city,
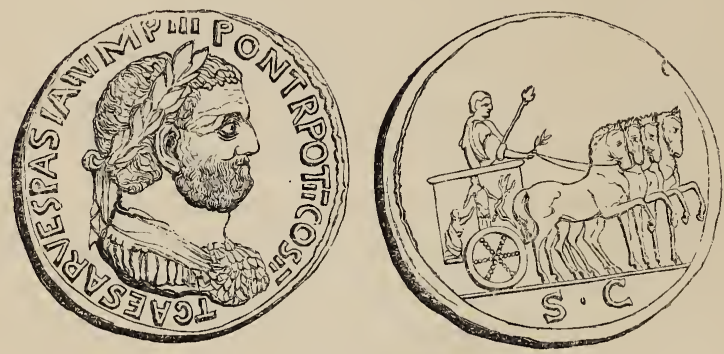

COIN OF TITUS.

perhaps saying, like the heathen of old, "Let our eye look upon Zion!" Across the elevated plain, which alone gave military access to this mountaingirt city, and from which every enemy, from Nebuchadnezzar downward, had attacked her, he leisurely advanced, gazing on the majestic towers and walls, and on the glorious Temple towering above all. All was quiet and still; not a soul appeared at the gates; it might have been a deserted city, or a city of the dead. And now the troop had crossed the little depression in which the valley of Jehoshaphat is gradually lost, and had ascended the gentle slope that brought them almost beneath the wall. Titus led the band, and had already turned out of the direct road, and was diverging towards the tower of Psephinus, which flanked the right hand corner of the northern wall, when suddenly one of the gates was flung open, and out rushed a host of 
armed men. The impetus of their sally broke in an instant the line of march, and the Roman commander found himself, with a few followers, isolated from his troop, and hemmed in by a host of infuriated adversaries on one side, and on the other by the trenches and hedges which inclosed the suburban gardens. Though destitute of both helmet and breastplate, for he had not anticipated such a greeting, the native valour of the Roman did not forsake him: the javelins and arrows flew harmless around his unarmed person, for he was "immortal till his work was done." He was the unconscious servant of the Most High God, who had given him a commission against His own city and people, and who might have said to him, as to Cyrus before, "I girded thee, though thou hast not known me." Till Jerusalem had fallen, Titus bore "a charmed life." Drawing his sword, he cut a way for himself through his daring foes, and regained the cohort from whom he had been separated. A rapid retreat was made to the camp, while the Jews returned to the city, elated with the knowledge that they had slain some, wounded many more, and repulsed all of the heathen foes, with Cæsar at their head, who had ventured to set their feet upon the holy mountain of Jerusalem.

On the next day Titus removed the Roman camp, reinforced by the legion that had been left at Emmaus, to the hill Scopus, where Cestius had encamped before. From this point a noble view of the whole city is presented, at less than a mile's distance, which is indicated in the name of the hill, signifying 
Prospect.* Another legion encamped about half a mile behind this, and a third on the Mount of Olives, to the east of Jerusalem.

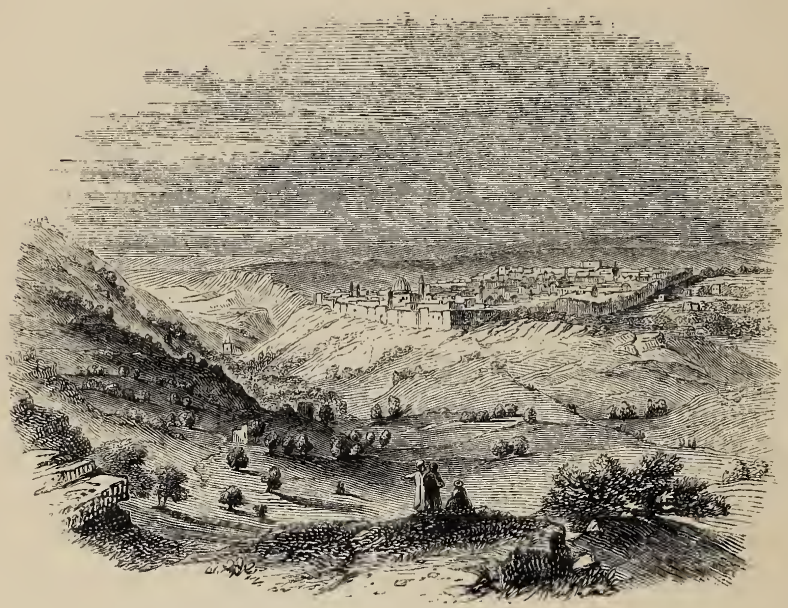

VIEW OF JERUSALEM FROM SCOPUS.

Glorious was the sight that met the eye of Titus as he gazed on the city before him. In the foreground was the gently undulating slope, covered with clumps of the graceful olive, interspersed with ancient mulberry-trees. In the bottom flowed the brook Kedron, brawling over its wide but shallow bed, till it was lost to view in the dark valley of Gethsemane, that wound round the steep side of Mount Moriah on the left. Up the acclivity in front stretched the road along which the troop had lately approached the city, and been driven

* From erotśw, to behold. 
back in undignified rout, bounded on either side by the gardens of flowers and fruit-trees, which were abundant in this quarter, divided by hedges, low stone walls, and trenches. The summit of the hill was crowned by the lovely city inclosed in its walls, which bound it round with a threefold girdle of massive stone. The morning rays of the sun gleamed from the ramparts and battlements, and towers of the nearest wall, and from the palaces, spires, and turrets of the city, that rose up street beyond street within, till the eye rested on Zion in the distance, the highest point of the whole; its rocky elevation covered with the castellated mansions and gorgeous palaces of the City of David. A Jew, on looking over this scene of grandeur and loveliness, would have involuntarily broken out into that glorious anthem of his shepherd king, which had so often resounded in swelling chorus from those sacred halls :-

Great is the Lord, and greatly to be praised in the city of our God, in the mountain of his holiness.

Beautiful for situation, the joy of the whole earth, is mount Zion, on the sides of the north, the city of the great King.

God is known in her palaces for a refuge.

But there was one object which must have filled the eye of every observer, and cast all others into the shade. Fairer than the white-walled city, fairer than the palaced height of Zion, rose the glorious Temple. Titus, heathen as he was, could have no sympathy with the holy associations which would crowd on the mind of a son of Abraham, as he looked on the surpassing edifice; but even Titus must have been 
enraptured with the gorgeous magnificence of that Holy House, whose architectural glory knew no rival in the whole world.

\author{
"__ Fair Jerusalem, \\ The holy city, lifted high her towers, \\ And higher yet the glorious temple reared \\ Her pile, far off appearing like a mount \\ Of alabaster, topt with golden spires." *
}

He saw "the court of the Gentiles circling the whole; a fortress of the whitest marble, with its wall rising six hundred feet from the valley; its kingly entrance worthy of the fame of Solomon; its innumerable and stately dwellings for the priests and officers of the Temple; and above them, glittering like a succession of diadems, those alabaster porticoes and colonnades, in which the chiefs and sages of Jerusalem had sat teaching the people, or walked, breathing the pure air, and gazing on the grandeur of a landscape, which swept the whole amphitheatre of the mountains." He saw, "rising above this stupendous boundary, the Court of the Jewish Women, separated by its porphyry pillars and richly sculptured wall; above this, the separated Court of the Men; still higher, the Court of the Priests; and highest, the crowning splendour of all, the central Temple, the place of the Sanctuary, and of the Holy of Holies, covered with plates of gold, its roof planted with lofty spear-heads of gold, the most precious marbles and metals everywhere flashing back the day, till Mount Moriah stood forth to the eye of the stranger approaching Jerusalem, what it had

* Paradise Regained, Book iv. 
been so often described by its bards and people, a mountain of snow, studded with jewels." *

Before we enter upon the details of the siege, which swept as with the besom of destruction the City and Temple, it will be needful to give a brief description of its walls. Jerusalem at this time consisted of three distinct portions, each inclosed by its own wall. The southern portion was the most ancient,

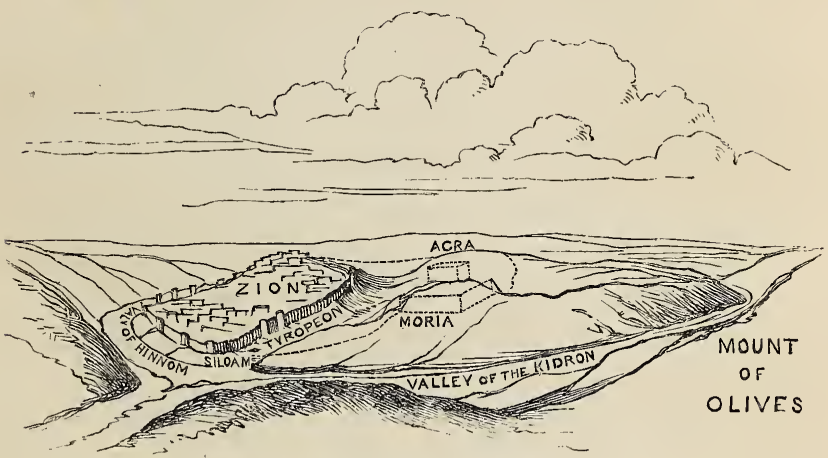

DIAGRAM OF JERUSALEM.

the rocky height of Zion. A deep ravine, called the Tyropœon, crossed by a bridge, separated it from Acra, or the Lower City, which was built on another hill to the northward, the highest peak of which, Mount Moriah, was crowned by the Temple. Northward still spread the town of Bezetha, originally a suburb, and called the New Town, but fortified with a wall by Agrippa. This was the weakest, as well as the least populous portion of the city. Everywhere,

* Salathiel, i. 23. 
except at this quarter, the walls looked down into precipitous ravines of great depth, which defied the approach of an enemy. To the west lay the Valley of Gihon, to the south, the Valley of Hinnom, and to the east, the Valley of Jehoshaphat.

The innermost wall was of great strength; it had been begun by David, and further strengthened by Solomon and his successors, down to Herod the Great. Beginning at the south-west corner of the Temple, where a bridge crossed the Tyropœon, it separated Zion from Acra by a line running nearly due west, which was strengthened by three towers of massive proportions, Mariamne, Phasaelis, and Hippicus. Thence sweeping round the hill of Zion, and following the edge of the precipice, it appears to have terminated at the south-eastern corner of the Temple, inclosing a small space on the west side of the Tyropœon, called Ophel.

The second wall, which defended the Lower City, began at the Tower Antonia, which formed the north-western corner of the Temple, and curving in a quadrant, joined the first wall at the gate Gennath, a little within the tower Hippicus. The third, which was never completed in the strength originally designed, ran along from the north-eastern angle of the Temple, overlooking the valley of the Kedron for nearly half a mile; thence turning sharply to the westward, it swept round in a curve to the tower Psephinos, the extreme north-west point of the city, and thence proceeded in a south-east line to the tower Hippicus, where it joined the wall of Zion. 
These walls were fortified by square towers of strong and massive masonry, solid to the height of about thirty-five feet, above which they were furnished with chambers, and cisterns for receiving rain-water. Of these towers the first wall had sixty, the second forty, and the outmost ninety.

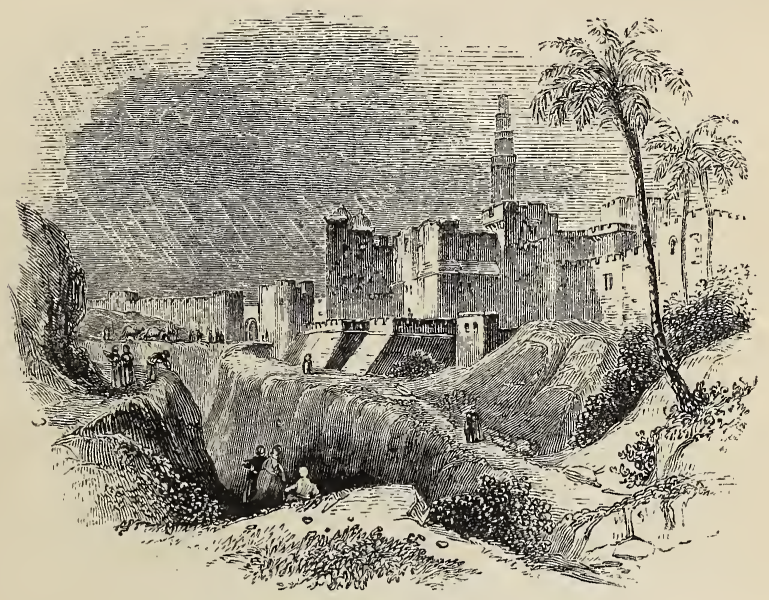

WALLS OF MODERN JERUSALEM.

"The beauty of these bulwarks was no less remarkable than their size and strength. They were built of white stone, hewn from the rock in blocks of enormous size, and so exactly fitted one upon another, as to present the appearance rather of an unbroken mass of marble than that of ordinary architecture. They rose to a great height above the walls; and these again being built, on three sides, upon the edge of a deep precipice, looked still loftier than they really were." One of these 
towers, believed to be the renowned Hippicus, is still standing, a solitary memorial of what once were the stately bulwarks of Zion, and abundantly justifying the proud appeal of the national anthem :-

Walk about Zion, and go round about her ; tell the towers thereof. Mark ye well her bulwarks, consider her palaces,

That ye may tell it to the generation following.

Psalm xlviii. 12, 13.

It is described as " a grand and striking object ;" the lower part entirely solid, as far as is known, no passage into it having been yet discovered. The dimensions of the east side are fifty-six feet four inches, of the south side seventy feet three inches: the large hewn stones of which it is composed average from nine to twelve feet in length. Josephus thus speaks of this tower, and of its two fellows, Phasaelis and Mariamne:-

"These were, for largeness, beauty, and strength, beyond all that were in the habitable earth; for besides the magnanimity of his [Herod's] nature, and his magnificence towards the city on other occasions, he built these after such an extraordinary manner, to gratify his own private affections, and dedicated these towers to the memory of those three persons who had been the dearest to him, and from whom he named them. They were, his brother, his friend, and his wife...... Hippicus, so named from his friend, was square, its length and breadth were each twenty-five cubits, and its height thirty, and it had no vacuity in it. Over this solid building, which was composed of great stones united together, there 
was a reservoir, twenty cubits deep, over which there was a house of two stories, whose height was twentyfive cubits, and divided into several parts, over which were battlements of two cubits, and turrets all round of three cubits high, insomuch that the entire height added together amounted to fourscore cubits." *

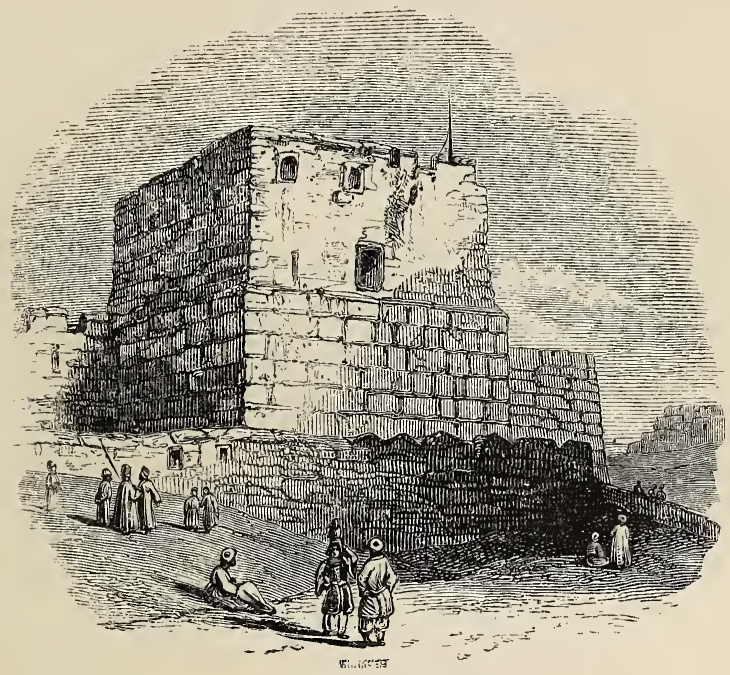

TOWER HIPPICUS.

The glory of the city was the Temple, which seemed to be no less a mighty fortress and tower of defence than a holy house of worship. The original edifice, erected by King Solomon on the spot where Abraham had offered up Isaac, had been razed to the ground by the King of Babylon; but, on the return from the captivity, a new structure had risen

* Josephus, Wars, V.iv. 3. 
from the ruins, which had been enlarged and beautified with extraordinary magnificence by Herod the Great, who had spared neither wealth, nor labour, nor time, in making it worthy of its name, as the only Temple of the true God in the world. "Forty and six years was this temple in building ;" but now,

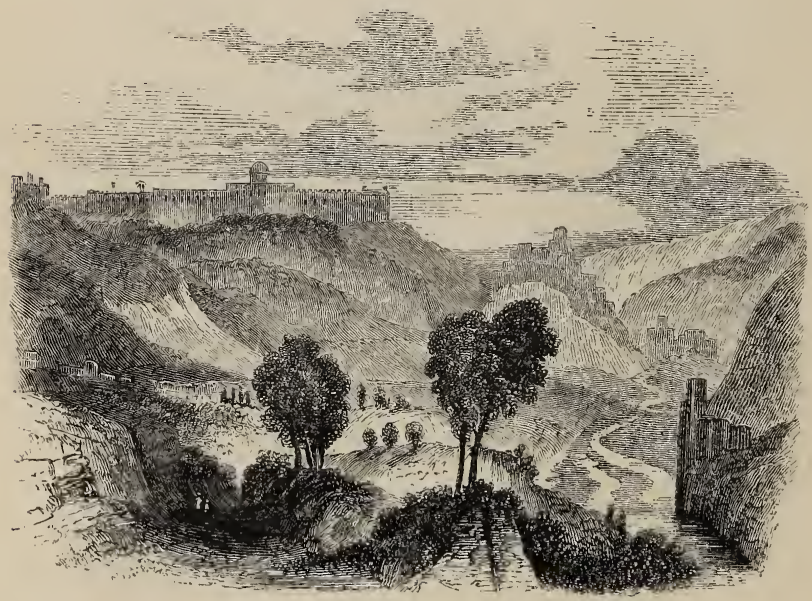

MOUNT MORIAH.

though its visible splendour remained, its true glory had long departed, and it was about to become the prey of the spoiler.

Of those great buildings, which elicited the wondering praise of every beholder, the foundations were not the least. "Great and strong walls had been built upwards on the sides of the hill, forming at their summits a square platform perfectly level, which was inclosed by adding to the lower walls 
a range of cloisters, that surrounded the Outer Court, communicating at one angle with Fort Antonia. This court was paved with a variety of stones ; and beyond it, inclosed by a second partition of peculiarly elegant workmanship, but only three cubits in height, surmounted by pillars, and ascended to by fourteen steps, was the Court of the Israelites, into which no Gentile might enter. On the eastern side of this quadrangle was the Women's Court, where the daughters of Zion assembled to worship; and here also stood another range of buildings, the height of which was not easily discernible from without. Four gates on the north, four on the south, and two on the east side, led to this court: the western wall was unbroken. Of these gates, nine were overlaid with silver and gold; but the tenth, which opened eastward, was far more magnificent, being of Corinthian brass, of considerably larger proportions than the rest, and adorned with double splendour, having the precious metals more profusely spread upon it, and with more elaborate ornament. These gateways were of such depth as to resemble towers, admitting of a room on either side within between the outer and the inner door. Some idea may be formed of the grandeur of these approaches when it is stated, that each door was in height thirty cubits, and its breadth fifteen; while the pillars that supported the chambers within the gateway were twelve cubits in circumference. The doors of the eastern, or 'Beautiful Gate,' which stood over against the entrance of the Temple itself, were forty cubits high. But the principal fea- 
ture of the whole pile of sacred edifices was the snowy whiteness of the polished stones that formed it, their enormous size, and the unbroken surface presented to the eye by means of such exquisite fitting of one to another as scarcely allowed any junction to be perceptible. Accustomed as they were to worship on that spot, and familiarized with the magnificence that there surrounded them, the disciples could not refrain from exclaiming, 'Master, see what manner of stones, and what buildings are here! " "*

Within the quadrangle thus formed there was yet another enclosure separated by a low wall: this was the Court of the Priests, and contained the great altar of burnt offering. Beyond appeared the great gate of the Temple itself, a magnificent archway without any doors, leading into the Holy Place. Its front was sheeted with plates of burnished gold, which seemed to flame upon the beholders. Above and around it hung a vine of gold (the sacred symbol of Israel), the clusters of which were as high as a man. By the votive offerings of worshippers, this golden vine was continually growing, for some presenting gold to make a leaf, some a bunch, and some a single grape, these were added to the branches in proper form and position, and ever increased the magnificent tree. Within stood the seven-branched candlestick, the table of shew-bread, and the altar of incense. The view was terminated by a magnificent veil, which hid from view the Holiest of all, whose walls were encased with gold, but which contained 
nothing, for the Ark seems never to have been replaced after the Babylonish captivity. Here, in former days, the Shechinah of Glory indicated the indwelling presence of Jehovah: but this also had long departed; and the Temple could now only boast of its material magnificence, which yet was so great as to dazzle and astonish the eyes of the beholders.

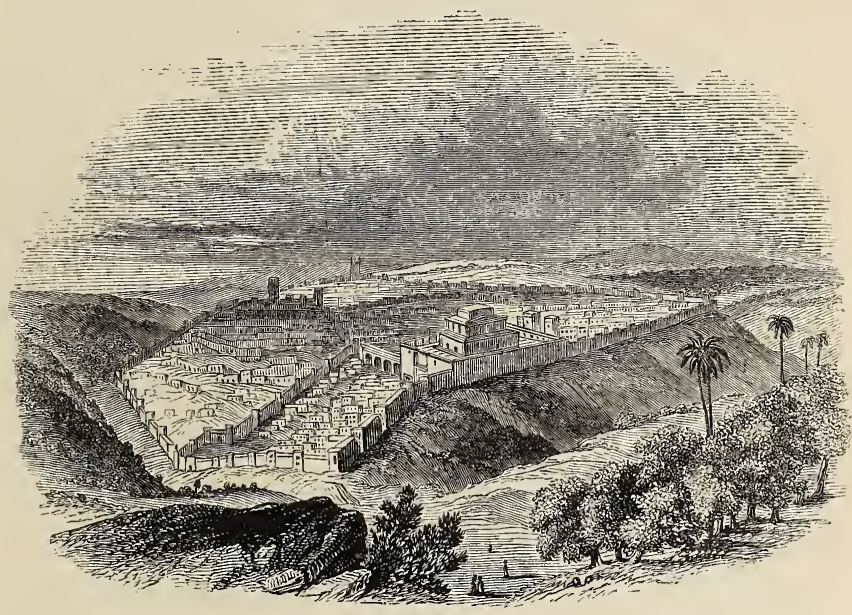

JERUSALEM FROM MOUNT OF OLIVES.

Even the external surface of the Temple was covered with plates of solid gold, which, reflecting back the beams of the morning sun when he first rose over the Mount of Olives, seemed at once to burst into an immense mountain of flame. The tenth legion, stationed on this hallowed Mount, would look with awe and wonder on the glories before them; and as the sun climbed higher up the 
sky, and the blaze of reflected light faded so as to reveal the beautiful details, they would gaze into the sacred courts through the stately colonnades of white marble, and catch many a gleam of the splendid foliage and tracery that ornamented the noble walls.

At the north-west angle of the outer court stood the Fort Antonia, the citadel of the city. It was built upon a precipitous rock, the steep sides of which were faced with smooth stone to prevent approach. It was a noble pile, combining the magnificence of a palace with the strength of a fortress; and was connected by galleries with the cloisters of the Temple. Formerly it had been the dwelling of the Roman garrison; but this had been long since ejected, and it seems to have now fallen into the possession of Simon.

Alas! alas! soon was that lamentation to be taken up :- "Our holy and our beautiful House where our fathers praised Thee is burned up with fire; and all our pleasant things are laid waste!" 


\section{CHAPTER VII.}

THE SIEGE.

A. D.70.

The sight of the Roman legions encamping around the city for a moment awakened the factions to a sense of their madness ; they formed a hasty agreement, and many of the Zealots rushing out fell suddenly on the tenth legion as it was encamping, and put it into disorder and rout. Titus sent aid to his panic-struck troops, and in some degree repelled the furious assault; but, having drawn off his forces to the summit of the mountain, the watchmen on the city walls supposed the movement to be a flight. Instantly they gave a signal to those within by violently shaking their garments; on which there poured forth from the gates a fresh host of Jews "6 with such mighty violence, that one might compare it to the running of the most terrible wild beasts." Down into the Kedron poured the living torrent, and swelled. up the sides of Olivet with an impetuosity that no. thing could resist: the historian likens the shock of that host upon the Roman legion to the violence of a mighty stone shot from a catapult; the armed and disciplined ranks were broken before it, and ran like deer up the mountain. Once more Titus was 
left almost alone in the midst of his enraged enemies, where, according to his flattering encomiast, Josephus, he performed prodigies of valour, sustaining his position till shame brought back the panic-struck legion, and turned the fortune of the day. The Jews at length retired to their walls; but retired as a lion retires when pressed by superior foes, slowly and sullenly, often turning at bay, and dealing destruction on the foremost of his foes.

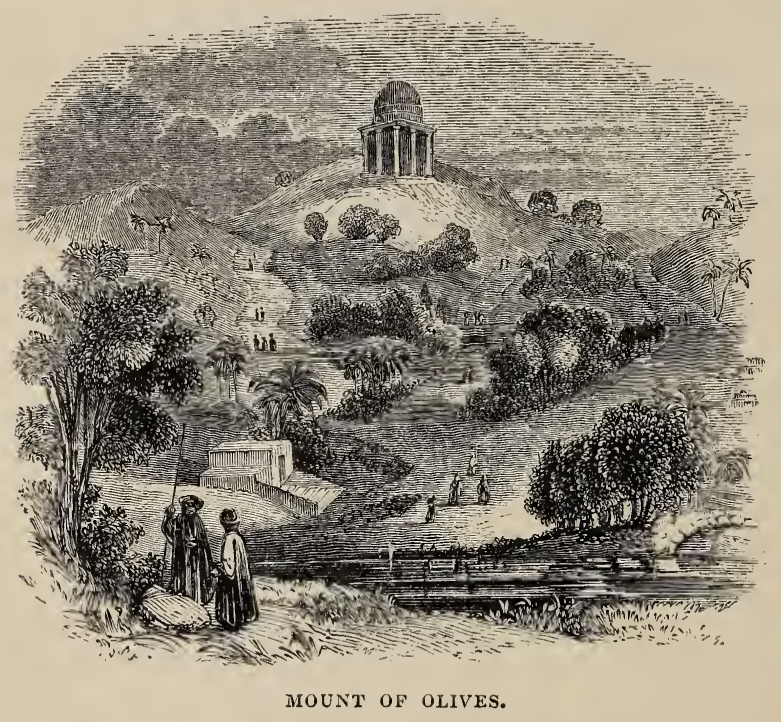

It was now the Feast of the Passover, in the year 70 , and the city was filled with the tribes, whom the presence of the Roman army and the prospect of the coming siege did not prevent from flocking thither to keep this the greatest and most august solemnity 
of the year. There seems to have been an awful retribution in the providence that, as it was at the Passover, when the whole Jewish nation was representatively assembled, that "the Heir" was cast out of the vineyard and slain, so it should be at the same grand national gathering, that "the Lord of the vineyard" should "send forth his armies and destroy those murderers, and burn up their city." Upwards of a million of people seem to have been shut up in this devoted city, nearly the whole of whom were " miserably destroyed," either by the fratricidal contentions and massacres of the factions, by famine, or by the Roman sword. So truly was the imprecation accomplished: "His blood be upon us, and upon our children !"

The league which had been hastily concluded between the rival parties was of very brief duration; for, immediately after, John obtaining entrance into the inner courts of the Temple by stratagem, conquered the opposition of Eleazar's faction, and reunited it to his own. By this coalition he obtained the command of eight thousand four hundred men, who held possession of the Temple, the quarter called Ophel, and the valley of the Kedron: the faction of Simon, on the other hand, that tyrannized over the Upper and the Lower City, and a good part of the suburb of Bezetha, amounted to ten thousand Jews and five thousand Idumeans. The flame of party-contention now burned all the more fiercely for the brief interruption of its fury.

Meanwhile the foe without was sternly and vigorously carrying on his preparations for the siege. The 
space that lay between Scopus and the northern wall was levelled, to admit a nearer encampment. This part was occupied by delightful gardens, whither the inhabitants had been wont to resort in the evenings of happier days to inhale the balmy air, to smell the perfume of fragrant flowers, to sit under the vine

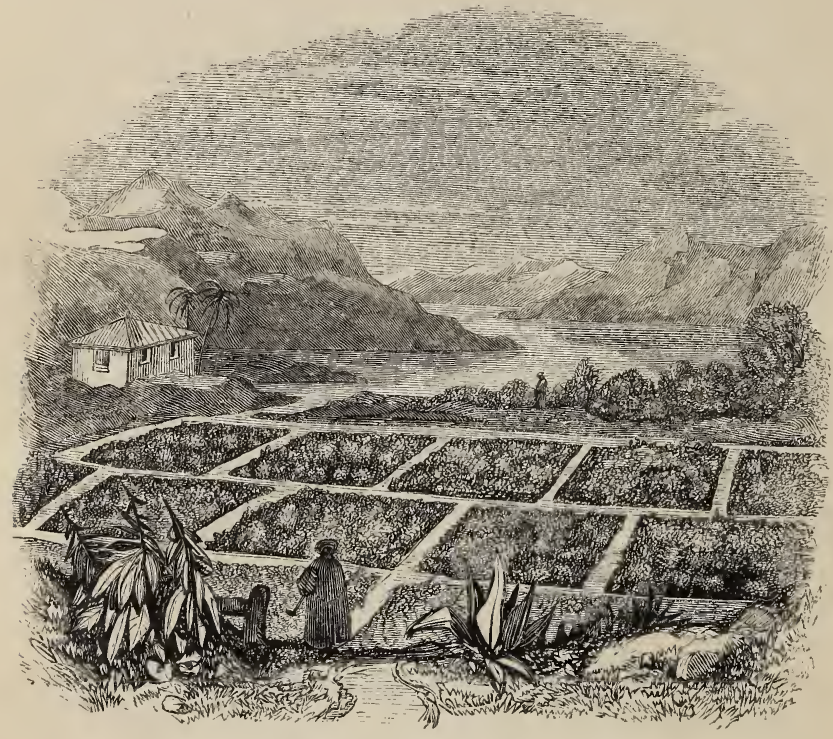

GARDEN IN JUDEA.

and the fig-tree, and to pluck the delicious fruit. These paradises were now in the flush of vernal loveliness; the spring rains had covered the shrubs with foliage, and the parterres were gay with a profusion of brilliant flowers; the shrubs and trees were, some of them, loaded with grateful fruit, and others covered with blossoms. All this beauty was ruthlessly 
destroyed by the iron hand of the spoiler; the hedges and walls were thrown down, the trees of beauty and fruitfulness rooted up, the trenches filled, and the very surface of the rock broken up and levelled with crows and axes of iron. Four days were occupied in this work; and then the ground, where nature had smiled in her sweetest beauty, bristled with the grim array of war. For the army was now brought

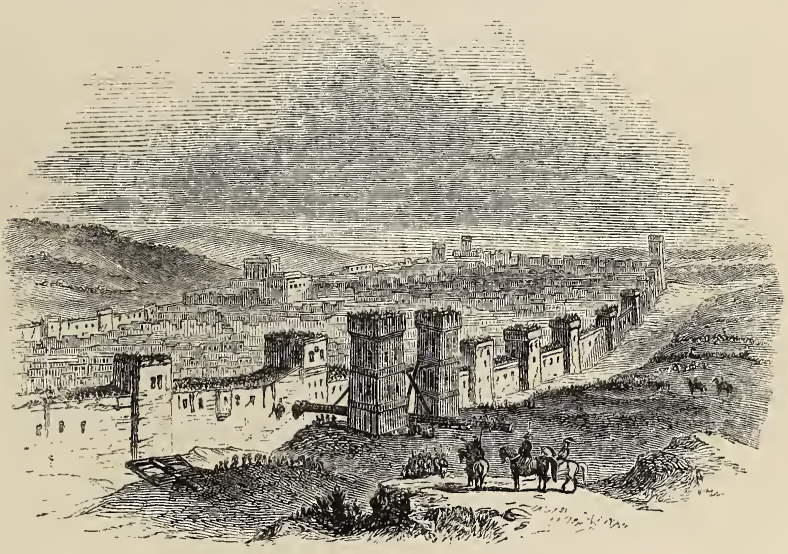

NORTH WALL.

up before the northern and western wall, seven deep, with the footmen placed in front and the horsemen behind them, in their ranks, while the archers stood in the midst in seven ranks. The encampment reached as far as the tower Hippicus on the west, and Titus seems to have occupied a central position, pitching his tent opposite the tower Psephinus, at the distance of a quarter of a mile from it. 
Having made a circuit of the city, that he might personally survey the walls, Titus set fire to the suburbs, and began to build an embankment for the use of his engines of war, so ordering his slingers and archers, that the builders might be protected against the impetuous sallies of the Jews. But the latter did not despair. Simon bravely manned the wall, and placed on it the military engines which had been captured from Cestius: but these could effect little in opposition to those of superior power, which were the pride of the besieging army.

"The method pursued by Titus against Jerusalem was the very same that was used by the Romans and other cultivated nations in all similar cases. It consisted in forming a bank (such as a railway exemplifies), approaching the wall by degrees as it tended to completion; and of such a height that, when finished, the besiegers might stand nearly on a level with the besieged. The materials of which the bank was formed varied according to convenience; earth was somewhat scanty in the rocky neighbourhood of Jerusalem, and timber was made available for the purpose. The workmen, that is the soldiery, employed in the construction of this embankment, would necessarily be much exposed to missiles from the besieged; and, for their protection, screens of every kind, penthouses, and hurdles were carried forward, preserved from the enemy's application of fire by coatings of iron, hides, or anything else that seemed best. For the same purpose of defending the workmen, the arts of the engineers were taxed to the utmost in the construction of machines, which should 
prevent the besieged from manning the walls at all. Towers in several stories, of an amazing height, were rolled on wheels towards the point of conflict, and in these were stationed companies of bowmen, slingers, and javelineers, assisted, perhaps, by small catapults, and the energies of all were directed to prevent a single hostile hand being raised against the banksmen or others. Machines for casting missiles with the greatest force were invented in vast

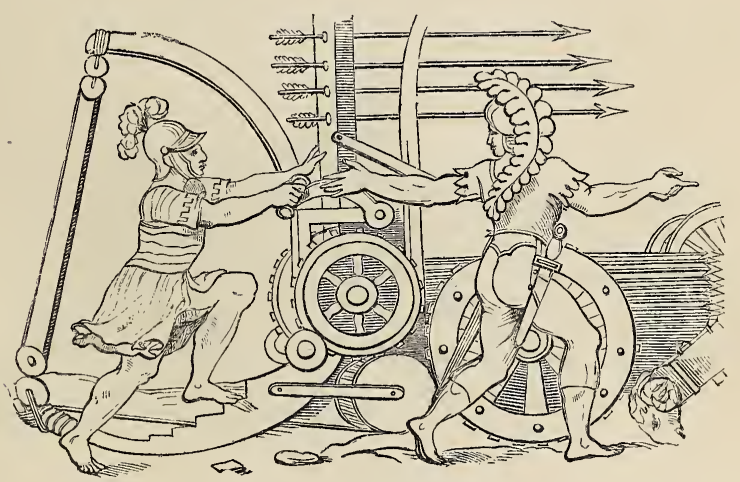

CatAPULT.

variety. In the principle of their construction they were of two kinds, catapults and ballistas. Catapults were enormous crossbows for the discharge of arrows ; and from them the arrow parted with a flight so rapid as to fetch sparks of fire from the groove by which it was directed. The ballista was essentially composed of a spring of tough wood, which was drawn by main force (or a screw, \&c.), to a horizontal position, and, when thus at full stretch, was 
suddenly liberated by the blow of a hammer, so that, being checked when vertical, it hurled the stones with which it was charged, not without considerable effect. Josephus, in the siege of Jotapata, saw a stone ball thus propelled strike off the head of a man by his side to the distance of three stadia (six hundred yards) like a bullet from a sling. 'In the fields about Ptolemais,' says Mr. Maundrell, 'we saw scattered up and down several large balls of stone, of at least thirteen or fourteen inches diameter.' At Beer, on the Euphrates, he saw others

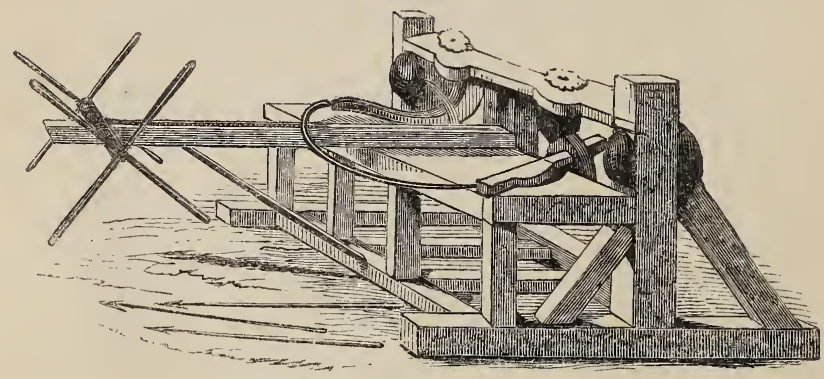

BALLISTA.

of twenty inches diameter. When by the superiority of the besieging army the mound had been driven up to the face of the wall, then the batteringram was brought into play. It shook the walls with the efficiency of cannon; and we shall see that the heavy fortifications of Jerusalem were unequal to resist it. Against these arts of the besiegers, the business of the besieged was to lay hold, one way or other, of the towers, penthouses, and machines with fire; by covering them with pitch, by throwing 
fire-balls, or burning combustibles attached to arrows and javelins upon them; to ply their own catapults and ballistas; to destroy the enemy's works by sallies; to catch them at favourable moments, and pour in showers of arrows; to sink their embankments by mines; to parry the blows of the ram by intercepting them with sacks of sand or wool, or by haling its head sideways by ropes : indeed, every method which their ingenuity could devise was gladly tried."*

Some of the engines were of extraordinary size and power, hurling stones of a hundred-weight to the distance of more than two furlongs. The Jews watched the discharge; and, as the shock of the engine produced a loud noise, and the whiteness of the stone made its headlong course very visible, they were able generally to avoid its blow by falling on their faces, on the cry of the watchman, "the son cometh!" This term of "the son," by which the stone was distinguished, has given rise to much speculation; yet it was probably but an abbreviation of "the son of destruction," a common Hebraism. At length the Romans, perceiving that the whiteness of the stones betrayed their approach, blackened them, and thus caused great havoc.

The pressure of the danger once more impelled the factions to unite in the common defence; and both parties joined in fierce sallies upon the besiegers, who fell upon the works, tearing up the protecting hurdles, and pulling the embankment to pieces whenever they could. In one of these irruptions an immense host rushed out from a gate near

* Cockayne's Civ. Hist. of Jews, 264. 
Hippicus with burning torches, and, falling on the Romans with irresistible impetuosity, put them to flight and set fire to the works. The engines, as well as the embankments, were in imminent peril of destruction; but Titus, having hastily led a troop of cavalry to the spot, succeeded in saving his works and repelling the heroic Jews. To the disgrace of the Roman commander, he ordered one of the brave defenders of their city, whom he had taken prisoner, to be crucified in front of the wall, for no other offence than valiantly fighting for his home and his Temple.

About this time a singular panic fell upon the Roman host. Titus had erected three of those enormous towers, which were then used in sieges, for the purpose of bringing his archers, slingers, and even the lighter engines, to a level with the battlements. About midnight it happened that one of these towers, fifty cubits high, suddenly fell down with a tremendous crash, probably owing to the settling of the embankment. Awakened out of their sleep by the noise, the army were greatly affrighted; their first thought was, that it was another of those daring sallies of the Jews, which they by this time knew how to appreciate. The darkness increased the alarm; and, though the historian does not say so, we may well imagine that their arms were used against each other before order and confidence were restored.

These lofty towers gave a great advantage to the besieging army. Being higher than the walls, the soldiers from the summit could throw their darts 
and shoot their arrows upon the Jews with great precision and effect, while the latter had little power in directing their missiles to adversaries above their heads. The catapults and ballistæ, too, though smaller than those on the ground, yet from the advantage of situation were able to sweep the walls of the defenders. The size and weight of the towers were such as to defy any efforts to overturn them in sudden sallies; and, to guard against the action of fire, which had already been fatally used against the works, they were sheathed with plates of iron. Thus the poor imprisoned Jews were compelled to abandon the defence of this part of the bulwarks, and to listen, in agonizing, because powerless, suspense, to the hollow blows of the rams, as they fell heavily in measured succession upon the quaking wall.

"What heart can conceive the terrors of this season, as experienced by those who were surround. ed, seeing no way of escape? We speak not of Jewish men so much as of the poor, weak, tender women and little ones, and of the very aged, some of whom had heard the thrilling sounds of compassionate warning, when, melted into sorrow, they followed the steps of the Holy Sufferer, who bore His cross along the proud and stately streets of the city, and bewailed the cruel death to which $\mathrm{He}$ was ignorantly doomed.

“ ' Daughters of Jerusalem,' he said, ' weep not for me, but weep for yourselves and for your children. For, behold, the days are coming, in the which they shall say, Blessed are the barren, and the wombs that never bare, and the paps which never 
gave suck. Then shall they begin to say to the mountains, Fall on us, and to the hills, Cover us.' Surely such must have been the language, secret, if not uttered, of the terrified females, as they stole a glance at the tremendous array of those camps, swarming with a horde of fierce, brutal, sanguinary, licentious devil-worshippers, who never knew what pity meant, and who were lured to the enterprise by nothing but the prospect of fully satiating all their vilest and most ferocious passions. Surely such must have been the mother's moan, as she looked on her beauteous children, and pictured to herself the horrors of a life-long slavery, with all its hideous accompaniments, including the torturing deaths reserved for multitudes, in the gladiatorial and other murderous spectacles of Rome. Imagination faints beneath the effort to realize for one moment what those endured who were now pent in by the tottering walls and towers of Jerusalem." *

The siege had now proceeded during fifteen days, when, on the seventh of Jyar (about the end of April), the great battering-ram, to which the Jews had given the name of Nico, or the Conqueror, made a breach in the outer wall. This gave the Romans admission into Bezetha, which they partly demolished, as they did also the wall through which they had entered; but the ancient city, both the Upper and the Lower, as well as the Temple, were still uninjured, and presented to the besiegers walls of greater strength than that which they had stormed. 
Titus now pitched his camp at a point called in memory of a glorious deliverance, "the Camp of the Assyrians," which seems to have been at the foot of Calvary. Here stood Rabshakeh and his host, when his insulting taunt was cast at "the virgin daughter of Jerusalem;" and here lay the proud Assyrian king himself, when he was made to hear the rebuke of Jehovah of Hosts whom he had defied, and to feel His vengeance.

Ant the King of Assyria sent Rabshakeh from Lachish to Jerusalem unto King Hezekiah with a great army. And he stood by the conduit of the upper pool in the highway of the fuller's field. Then came forth unto him Eliakim, Hilkiah's son, which was over the house, and Shebna the scribe, and Joah, Asaph's son, the recorder. And Rabshakeh said unto them, Say ye now to Hezekiah, Thus saith the great king, the king of Assyria, What confidence is this wherein thou trustest? I say, sayest thou, (but they are but vain words) I have counsel and strength for war: now on whom dost thou trust, that thou rebellest against me?

Thus saith the king, Let not Hezekiah deceive you: for he shall not be able to deliver you. Neither let Hezekiah make you trust in the LorD, saying, the LoRD will surely deliver us: this city shall not be delivered into the hand of the King of Assyria. Hearken not to Hezekiah: for thus saith the King of Assyria, Make an agreement with me by a present, and come out to me: and eat ye every one of his vine, and every one of his fig-tree, and drink ye every one the waters of his own cistern ; until I come and take you away to a land like your own land, a land of corn and wine, a land of bread and vineyards. Beware lest Hezekiah persuade you, saying, The LorD will deliver us. Hath any of the gods of the nations delivered his land out of the hand of the King of Assyria? Where are the gods of Hamath and Arphad? where are the gods of Sepharvaim? and have they delivered Samaria out of my hand? Who are they among all the gods of these lands, that have delivered their land out of my hand, that the LoRD should deliver Jerusalem out of my hand?

And Hezekiah prayed unto the LoRD. 
Then Isaiah the son of Amoz sent unto Hezekiah, saying, Thus saith the Lord God of Israel, Whereas thou hast prayed to me against Sennacherib King of Assyria: this is the word which the Lord hath spoken concerning him; the virgin, the daughter of Zion, hath despised thee, and laughed thee to scorn; the daughter of Jerusalem hath shaken her head at thee. Whom hast thou reproached and blasphemed? and against whom hast thou exalted thy voice, and lifted up thine eyes on high? even against the Holy One of Israel.

Therefore thus saith the LoRD concerning the King of Assyria, He shall not come into this city, nor shoot an arrow there, nor come before it with shields, nor cast a bank against it. By the way that he came, by the same shall he return, and shall not come into this city, saith the LoRD. For I will defend this city to save it, for mine own sake, and for my servant David's sake.

Then the angel of the LORD went forth, and smote in the camp of the Assyrians an hundred and fourscore and five thousand: and when they arose early in the morning, behold, they were all dead corpses. Isa. xxxvi. xxxvii.

But now no miraculous interposition appeared; no angel of death smote the beleaguering host; for Israel's "Rock had sold them, and the LonD had shut them up."

From the tower Hippicus to the valley of the Kidron the second wall was now exposed to the attacks of the Roman army; but it was as vigorously defended. John and Simon, forgetting their mutual animosities, strove to outvie each other in valour and energy,- - the former defending the Temple and the Antonia, the latter manning the wall from the monument of John the High Priest to Hippicus. The fighting-men were animated with the strongest devotion to these their leaders, so that danger and death were defied in the execution of their commands. Sallies became more and more frequent, and prodigies of valour were performed on both 
sides; the day seemed too short for the zeal of the combatants, and the night was passed in armour.

At length, after five days had been occupied in the assault of the second wall, one of its towers fell before the mighty battering-ram, and Jerusalem lay open to the Romans. The part of the city which was now exposed was traversed by close and narrow streets, obliquely leading from the wall, and densely peopled by the clothiers, woolstaplers, and braziers. This quarter Titus proceeded to occupy with a thousand choice troops, but abstained from breaking down the wall or dismantling the fortifications, while he prohibited his soldiers from pillage and massacre. There was doubtless as much of policy as of mercy in this moderation: he was desirous of preserving the magnificent Temple for his own glory, and was therefore reluctant to push the inhabitants to desperation; he knew, moreover, that there was a large party in the city not averse to submission, but overawed by the prowess of the factions. His leniency, however, injured himself; for the exasperated populace burned with indignation at the presence of the Romans, and fell on them with fury in the narrow lanes. As usual in street-fighting, the populace had the best of it; for they fought with the immense advantage of numbers, and of situation, knowing the turns, concealments, and shifts, and being able from the roofs and windows of the houses to pour down darts, stones, and all sorts of viler missiles upon their heavy-armed and pent-up adversaries. In vain the humbled and affrighted Romans rushed up and 
down the endless lanes, with lamentable cries, to find the breach by which they had entered; and when they did find it, it was so narrow that but a few could pass at a time. Many were slain, and the whole would doubtless have left their bleeding corpses in the streets of Acra, had not Titus obtained succours, and secured to the survivors an ignominious retreat.

For three days afterwards the Romans vainly strove to re-enter the breach; for the valiant Jews, with a noble contempt of danger, and animated, too, by their recent victory, presented their armed bodies at the opening, as an impregnable wall; nor was it until the fourth day that the vehement assaults of Titus with his whole available force, broke through that living barrier, and gave him a second time possession of the city. Improving by his late experience, he now razed a large part of that wall, and garrisoned those towers of it that.were nearest to Zion.

The periodical pay-day of the Roman troops had now arrived, and Titus determined to use the occasion for a grand pageant, with the double purpose of gratifying the pride and elating the spirits of his own soldiers, and of infusing terror into the hearts of the besieged. The legions defiled before their commander in battle array, with all the glittering pomp of a review. The accoutrements of a Roman legion were not made for superfluous ornament, but those who conceived the system knew the value of show. The helmets and cuirasses of the common soldier were of glittering brightness, and on parade-days, when these were divested of their 
ordinary leathern cases, the flash and play of light was a splendid spectacle. The arms of the officers were frequently inlaid with the precious metals, and they rode gorgeously-caparisoned chargers, purchased at enormous prices from the finest studs of Europe and Asia. The splendour was greatly heightened by the multitude of banners that danced in the air. "Every emblem that mythology could feign, every memorial connected with the history of soldiership and Rome, glittered above the forest of spears; gilded serpents, wolves, lions, gods, genii, stars, diadems, imperial busts, and the eagle paramount above all, were mingled with vanes of purple and embroidery. The most showy pageant of civil life was dull and colourless to the crowded magnificence of the Roman line." *

For four days this gorgeous sight was displayed in front of the wall, before the whole of the legionaries had received their pay: the Jews thronged to behold it; the whole of the northern cloisters of the Temple, and the wall of Zion, were full of crowded spectators, and the roofs and windows of the houses were occupied with anxious faces, gazing on the spectacle with mingled expressions of wonder and consternation. But it passed away, and no sign of submission, no appeal for mercy, came from the forlorn city: its inhabitants had taken their determination, and were sternly resolved to keep it. Yet the sunken eyes and gaunt features of those gazers told that famine was in the city, adding its horrors to those that before prevailed.

* Salathiel, ii. 281. 
Titus now pressed the siege with vigour, ordering the erection of new embankments; one against the Antonia, with a view to take the Temple, and another opposite the High Priest's monument, against the wall of Zion. But the former was greatly impeded by John, and the latter by Simon; for these leaders still made frequent and impetuous sallies, besides harassing the troops by a vigorous fire from the walls. The Jews, by practice, had now attained skill in the use of military engines; and as they had no less than three hundred catapults and forty ballistæ, which continually hurled stones and darts from the walls, the embankments proceeded but slowly. Josephus was therefore commissioned to speak to his countrymen on the wall, and to try his arts of persuasion; but they paid little respect to the exhortations of one whom they well knew as a worthless renegade.

Individuals, however, endeavoured to flee from the miseries that were encompassing them; and that they might not be wholly destitute, swallowed pieces of gold before they crept out. Some of these contrived to escape into the country, though the slightest suspicion of such an intention was enough to insure the death of any one.

The scarcity of provisions was now so great, that the armed bands continually searched for it, breaking into private houses, and torturing the inmates to induce them to discover their stores. Those who were plump and in good case, were marked as possessing food, and compelled to give it up: "old men who held their food fast were beaten, and if 
the women hid what they had within their hands, their hair was torn for so doing;" children were lifted up and dashed upon the floor, to make them forego the morsels which they were eating, and to which they clung with the pertinacity of famine. Some, who crept out into the valleys to pick up wild herbs and roots, or to glean garbage from the verge of the camp, were watched as they came back, and robbed of the sordid spoil. Many sold all their property for a single measure of corn, then shutting themselves into a closet would eat the whole at a meal, and die. "Every kind feeling,-love, respect, natural affection,-was extinct through the all-absorbing want. Wives would snatch the last morsel from their husbands, children from parents, mothers from children; they would intercept even their own milk from the lips of their pining babes."

Those who were in the enjoyment of any degree of opulence or dignity were the prey of Simon and John: it was enough to accuse them of intending to desert, when they were instantly slain and their property confiscated. The factious captains affected a sort of courtesy in their abominations; he who had been plundered by John being handed over to Simon, and the contrary. They emulated each other in wickedness, and the one would think himself aggrieved if the other surpassed him in any barbarity. The historian delivers it as his solemn verdict, " that neither did any other city ever suffer such miseries, nor did any age ever breed a generation more fruitful in wickedness than this was, from the beginning of the world." 
The circumstance of the poor starved wretches creeping forth to gather food, having been reported to Titus, he set ambushes to capture them. Five hundred in a day, and sometimes more, were thus taken, who, with horrible cruelty, were scourged and otherwise tortured, and then crucified in front of the walls. The merciless soldiery even amused themselves by nailing these miserable beings to the crosses in various contorted postures. At length the multitude of those so treated became so great, that " room was wanting for the crosses, and crosses wanting for the persons." How awful a retribution on that sinful Jerusalem, whose maddened multitudes only seven-and-thirty years before, had been " instant with loud voices, requiring that the Holy One of God should be crucified!" Perhaps among the number thus treated, were some of the very individuals who had then headed the crowds; from whose furious lips had burst forth the cry, "Away with him! away with him! Crucify him! crucify him!" 


\section{CHAPTER VIII.}

THE SIEGE (continued).

A.D. 70 .

"A voice of wailing is heard out of Zion, How are we spoiled! we are greatly confounded, . . . for death is come up into our windows, and is entered into our palaces, to cut off the children from without, and the young men from the streets!" Jer. ix. 19-21.

IT was about the end of the month Jyar, when, after seventeen days of hard labour, the Roman embankments were completed. Four enormous banks now frowned upon the city, two near the Antonia, and two others near the High Priest's monument, facing the wall of Zion. But, meanwhile, another work had been going on from within, of which the assailants little dreamed. For John had excavated a mine beneath the wall of the Antonia, extending it under the banks of that quarter; as his work proceeded, he had supported the ground with beams and uprights, and filled the cavity with faggots besmeared with pitch and sulphur; and now, when the Romans were congratulating themselves on the success of their labours, and trusting that as soon as the engines were brought up, the wall must give way, the Jewish chieftain set fire to his mine. The beams were soon burnt through, and the whole 
embankments suddenly fell in with a prodigious noise. The volumes of smoke and dust that arose, for a few minutes concealed the character as well as the extent of the mischief; but the huge mass of flame that presently broke out, as the new materials descended into the fiery cavity, seemed to the astonished Romans the funeral pyre of their fond hopes.

The other two banks were protected by the peculiarities of their situation from a similar stratagem, and on these the military engines were planted, and already began to shake the wall with their heavy blows. But three heroic Jews, each bearing a torch, suddenly rushed out, and breaking through the midst of the enemy, regardless of the javelins that were hurled at them in showers, set fire to these machines. The Romans came thronging to save their engines, but were met by fresh bodies of elated antagonists from the walls. The battle raged fiercely around the flaming engines; the Romans endeavouring to drag them out of the fire, while the gallant Jews held them fast, nor would the heroic Three relinquish their hold of the great battering-ram, though it was now encompassed with flame, and though the iron was become red-hot. Meanwhile the fire had caught hold of the embankments themselves, and was raging with a fury that soon decided the fate of these no less certainly than that of their fellows. The Romans saw the mighty works, which they had constructed with weeks of weary labour, demolished by three famished Jews in an hour; and, depressed and crest- 
fallen, retired sullenly to their camp. But the Jews, rejoicing in their glorious success, came pouring down from the heights of Zion with an impetuosity that nothing could resist, and actually proceeded so far as to attack the fortifications of the enemy's camp, slaying the guards, who dared not desert their posts, and spreading panic through the host. Titus, who had been at the Antonia, seeking a place for the erection of new embankments, arrived at this crisis, and found his army besieged, and almost taken. Not a moment was to be lost: wheeling round with some chosen troops, he fell upon the flank of the Jews, and prevented the arrival of fresh multitudes from the city. The latter, however, did not flinch, but facing round continued the battle, both in front and rear, with unabated valour and constancy. Having fully succeeded in demolishing the threatening works of the enemy, and spread terror through his camp, they at length made good their retreat within their walls. Disappointed and baffled, Titus called a council of war to deliberate on measures now to be adopted; when it was determined to build a wall round the whole city, thus cutting off the possibility of its obtaining even the smallest succours from without, and rendering comparatively powerless the impetuous sallies of the garrison from within. To determine was to act; and so energetically did the legions labour at this work, that in three days it was completed, and Jerusalem saw herself inclosed by a wall of five miles in length, bristling with fortress-towers, like a huge serpent that had wound his fatal coil 
around her, and whose mortal embrace would never be relaxed until she lay a shapeless and smoking ruin. Then began to be fulfilled the great and dreadful day of vengeance, the foresight of which had wrung from the pitying heart of the Lord Jesus tears of sorrow.

And when he was come near, he beheld the city, and wept over it, saying, If thou hadst known, even thou, at least in this thy day, the things which belong unto thy peace! but now they are hid from thine eyes. For the days shall come upon thee, that thine enemies shall cast a trench about thee, and compass thee round, and keep thee in on every side, and shall lay thee even with the ground, and thy children within thee; and they shall not leave in thee one stone upon another; because thou knewest not the time of thy visitation. Luke xix. 41-44.

"Then did the famine widen its progress, and devoured the people by whole houses and families: the upper rooms were full of women and children that were dying by famine, and the lanes of the city were full of the dead bodies of the aged; the children also and the young men wandered about the market-places like shadows, all swelled with famine, and fell down dead wheresoever their misery seized them. As for burying them, those that were sick themselves were not able to do it; and those that were hearty and well were deterred from doing it by the great multitude of the dead bodies, and by the uncertainty there was how soon they should die themselves; for many died as they were burying others, and many went to their coffins before that fatal hour was come! Nor was there any lamentation made under these calamities, nor were heard any mournful complaints; but the famine confounded all natural passions, for those who were just going 
to die looked upon those that were gone to their rest before them with dry eyes and open mouths. A deep silence, also, and a kind of deadly night had. seized upon the city." *

The LonD hath purposed to destroy the wall of the daughter of Zion: he hath stretched out a line, he hath not withdrawn his hand from déstroying: therefore he made the rampart and the wall to lament; they languished together.

Her gates are sunk into the ground; he hath destroyed and broken her bars: her king and her princes are among the Gentiles : the law is no more ; her prophets also find no vision from the LoRD.

The elders of the daughter of Zion sit upon the ground, and keep silence : they have cast up dust upon their heads; they have girded themselves with sackcloth : the virgins of Jerusalem hang down their heads to the ground.

Mine eyes do fail with tears, my bowels are troubled, my liver is poured upon the earth, for the destruction of the daughter of my people ; because the children and the sucklings swoon in the streets of the city.

They say to their mothers, Where is corn and wine? when they swooned as the wounded in the streets of the city, when their soul was poured out into their mothers' bosom.

What thing shall I take to witness for thee? what thing shall I liken to thee, $O$ daughter of Jerusalem? what shall I equal to thee, that I may comfort thee, $\mathrm{O}$ virgin daughter of Zion? for thy breach is great like the sea: who can heal thee? Lam. ii. 8-13.

The dread of pestilence had induced the factious chiefs to rescind their former tyrannical edict against the burial of the dead, and for some time the bodies had been interred at the expense of the public treasury. But the rapidly-increasing progress of death rendered this now impracticable, and the only resource was to throw the corpses over the wall into the valleys that lay beneath. It is reported that Titus, in going his rounds through these valleys,

* Josephus. Wars, v. xii. 3. 
when he saw them full of dead bodies festering in the sun, with the thick putrefaction running about them, could not help groaning at the sight, and appealed to God that he was not a willing occasion of such horrors. But still no signal of submission was hung out upon the wall, no gate was opened to admit the besiegers, no band of deputed elders came forth with terms of capitulation: Jerusalem still maintained her stern resolve, to die, if need were, beneath the ruins of her Temple and palaces, but not to yield.

Many of the more timorous sort, however, contrived to desert to the Romans, notwithstanding the vigilance and severity of the garrison: but now a dreadful fate befel these. The artifice of swallowing pieces of gold before leaving the city having become known in the camp, the avidity of the soldiers, particularly of the Arabian and Syrian mercenaries, became excited, and with horrible barbarity they cut open the bellies of all such as they intercepted, searching for gold. Josephus narrates the shocking fact that, in one night, above two thousand of these deserters were thus massacred.

Titus expressed great indignation when this practice was made known to him; but, though he uttered severe threats of instant death if any should afterwards be found guilty of such barbarity, the love of money was stronger than the fear of punishment, and the practice was still pursued, though with more secrecy than before.

Some idea may be formed of the horrors of the siege from the statement made to Titus about this 
time by a deserter, who had been appointed to pay the public stipend for carrying out dead bodies. $\mathrm{He}$ affirmed that, between the 14th of Nisan and the 1st of Tamuz, a period of two months and a half, there had been carried out, at that one gate, which had been under his care, 115,880 corpses. This did not include those whose bodies were interred privately. Others endeavoured to estimate the total number of the poor who had died, and they asserted that no fewer than 600,000 had been then thrown out at the gates; that, when they could no longer carry them out, they laid the corpses in vast heaps in large empty houses, and shut them up. These reported, also, that a medimnus (about thirteen gallons) of wheat sold in the city for a talent (which was equal to about 133l. sterling per bushel); and that, when it was not possible to gather herbs, on account of the Roman wall of circumvallation, "some persons were driven to that terrible distress as to search the common sewers and old dunghills of cattle, and to eat the ordure which they found there!"

But far worse than all this remains to be told. There was a lady, eminent for rank and opulence, named Mary, the daughter of one Eleazar, who had fled from Peræa to take refuge in the city of Jerusalem. Her property had been plundered by the rapacious Zealots, who had continually broken open her house till they had robbed her of even the last morsel of food, and of everything which might have procured it. The famine pierced, to use the historian's expression, "through her very bowels and marrow," and steeled her heart against the strongest of all 
natural affections. She had an infant sucking at her breast; him she slew and roasted; and, having eaten part of her horrible repast, concealed the remainder. The odour of food attracted the famishing Zealots prowling in the neighbourhood, who, bursting in, threatened her with instant death if she did not give up what she had prepared. She replied that she had saved it for them, and, uncovering the dish, displayed the remains of her infant. Even these hardened ruffians were horrified and amazed, and went out trembling without a word, while the sad intelligence soon spread through the city, and even to the Roman camp, filling both with consternation.

The hands of the pitiful women have sodden their own children : they were their meat in the destruction of the daughter of my people. Lam. iv. 10.

And now let us turn from this narrative, with its sad minutiæ of detail, and read the solemn word of prophecy in which this very act had been predicted by God, with equal minuteness, fifteen hundred years before; and, comparing the prophecy with the narrative, let us adore the inscrutable knowledge of Him "who seeth the end from the beginning."

The LORD shall bring a nation against thee from far, from the end of the earth, as swift as the eagle flieth; a nation whose tongue thou shalt not understand ; a nation of fierce countenance, which shall not regard the person of the old, nor shew favour to the young: and he shall eat the fruit of thy cattle, and the fruit of thy land, until thou be destroyed: which also shall not leave thee either corn, wine, or oil, or the increase of thy kine, or flocks of thy sheep, until he have destroyed thee. And he shall besiege thee in all thy gates, until thy high and fenced walls come down, wherein thou trustedst, throughout all thy land : and he shall besiege 
thee in all thy gates throughout all thy land, which the LoRD thy God hath given thee; and thou shalt eat the fruit of thine own body, the flesh of thy sons and of thy daughters, which the Lond thy God hath given thee, in the siege, and in the straitness, wherewith thine enemies shall distress thee : so that the man that is tender among you, and very delicate, his eye shall be evil toward his brother, and toward the wife of his bosom, and toward the remnant of his children which he shall leave: so that he will not give to any of them of the flesh of his children whom he shall eat: because he hath nothing left him in the siege, and in the straitness wherewith thine enemies shall distress thee in all thy gates. The tender and delicate woman among you, which would not adventure to set the sole of her foot upon the ground for delicateness and tenderness, her eye shall be evil toward the husband of her bosom, and toward her son, and toward her daughter, and toward her young one that cometh out from between her feet, and toward her children which she shall bear: for she shall eat them for want of all things secretly in the siege and straitness wherewith thine enemy shall distress thee in thy gates. Deut. xxviii. $49-57$.

As soon as the wall of circumvallation was complete, Titus turned his attention to the replacing of those banks which the Jews had destroyed, but without which the siege could not be prosecuted: for on them the military engines must be raised to attack the walls. To erect them, however, was no easy task, for the whole of the timber-trees that had been growing in the neighbourhood of the city had been cut down for the construction of the former. But it was indispensable to procure more; and though the legions had to seek for materials at a distance of eleven or twelve miles from the city, their indomitable perseverance succeeded in raising against the tower of Antonia four banks larger than before, in the space of twenty-one days. The effect, however, was the entire desolation of the surrounding country; and the beautiful suburbs and environs 
of the city, which formerly had been adorned with trees and pleasant gardens, now lay a desert waste, wholly deprived of its loveliness; so changed that " one who had known the place before, coming suddenly to it now, would not have recognised it."

On the banks thus raised both the Romans and the Jews looked with peculiar interest; the latter, because they knew that, unless they could destroy them as they had done their predecessors, the wall must speedily yield; the former, because, if these were demolished, they could not hope to erect any more, and must despair of storming the city. Hence both parties were more than usually concerned about them; and while, on the one hand, they were assailed with the utmost vehemence, they were defended on the other with the most determinate pertinacity.

The engines, however, were at length elevated, and the blows of the heavy rams fell upon the solid masonry of the Antonia. For a while it seemed to resist; but the legionaries, having made a sort of defence with their shields, began to work at the foundation of the wall. With immense labour they succeeded in loosening some of its stones; and during the night that part of the wall which had been undermined before by John gave way before the ram, and fell in ruins.

When morning dawned the elation of the Romans was somewhat damped by the discovery of another wall, which the providence of $\mathrm{J}_{\mathrm{ohn}}$ had erected within the one now fallen; and their hopes of entering the city were to be still longer delayed. To 
attack this new wall was an exploit which needed no common daring, for it was valiantly defended. None for a time would venture on the hazardous enterprise; and when, stimulated by the exhortations and promises of Titus, one and another offered themselves, and a gallant band of twelve at length mounted the breach, they were all slain, or driven back desperately wounded.

But two days afterwards another little band of daring men, about sixteen in all, assembled an hour or two before day, and, clambering up among the ruins of the fallen wall, got up to the Antonia. Here they found the sentinels asleep, and, having cut their throats, they found themselves in possession of the wall, and sounded a trumpet.

The shrill blast, awakening the Jewish garrison out of their deep sleep, gave them the impression that the whole Roman host was upon them; and they fled panic-struck from the little band, whom they might with ease have thrown over the battlements. But on Titus and his army that trumpet-note awakened far different emotions, for it was the signal of success! Hastily gathering his principal officers and chosen men, he led them up the breach, and joined the gallant band who had won for him the citadel of the city, the fortress Antonia. And now commenced a most desperate contest, maintained on both sides with inflexible pertinacity, for the prize for which they contended was no less than the glorious Temple. The Jews had already rallied, and fought with the indomitable valour which had from the earliest times been characteristic of their lion-like tribe. 
Judah is a lion's whelp; from the prey, my son, thou art gone up : he stooped down, he couched as a lion, and as an old lion; who shall rouse him up? Gen. xlix. 9.

Behold, the people shall rise up as a great lion, and lift up himself as a young lion: he shall not lie down until he eat of the prey, and drink the blood of the slain.

He hath as it were the strength of an unicorn: he shall eat up the nations his enemies, and shall break their bones, and pierce them through with his arrows. He couched, he lay down as a lion, and as a great lion: who shall stir him up? Numb. xxiii. 24, xxiv. 8, 9 .

Not with javelins, nor spears, nor engines of war, but hand to haind and sword to sword was this battle fought; the combatants were intermingled without order in the narrow galleries that led from the Antonia to the Temple courts. The Jews came crowding in from the city, each willing to sacrifice his life in defence of the Holy House ; the Roman legions also, as they slowly mounted the breach and scaled the tower, continually reinforced the combatants. Immense slaughter was made, and the dead and wounded were crushed into an indistinguishable gory mass by the mailed feet of the fighters. Ten hours had the battle now lasted: for it had begun at the ninth hour of the night, and it was now afternoon. Jewish heroism once more proved itself superior to Roman prowess; and at length Titus, baffled and disappointed, sullenly relinquished the contest, and drew his forces into the Antonia.

Such was Judah in the day of his despair, haggard with famine, weakened by intestine discord, and, more than all, forsaken by his God! What was he in ancient days, when "the Lord his God was with him, and the shout of a King was among 
them?" what will he be yet again, when "the LorD of hosts shall visit his flock, the house of Judah, and make them as His goodly horse in the battle ;" when " they shall be as mighty men, which tread down their enemies in the mire of the streets in the battle; and they shall fight because the LorD is with them, and the riders on horses shall be confounded ?"* For "the remnant of Jacob shall be among the Gentiles in the midst of many people as a lion among the beasts of the forest, as a young lion among the flocks of sheep; who, if he go through, both treadeth down and teareth in pieces, and none can deliver." $\dot{\phi}$

That sad day was now come, the seventeenth of Tamuz, which the Jews in their sorrowful dispersions have ever since observed as a mournful fast; since which "the children of Israel have abode many days without a king, and without a priest, and without a sacrifice." \$ A bitter cry rose up from the Temple, and was echoed from the desolate city: the Daily Sacrifice was no more! The mighty famine, ever stalking on like a giant, had exhausted the supply of beasts for the offering; and death, in various hideous forms, the sword, the dearth, the pestilence, had thinned the company of priests till there were no more men to offer it. Titus heard the intelligence, and took occasion to exhort the garrison to save the Temple from spoliation by submitting to him; but Josephus, who bore the message, was assailed from the walls with reproaches and imprecations. The near view of the magnifi-

* Zech. x. 3, 5 .

+ Mic. v. 8.

$\ddagger$ Hos. iii. 4. 
cence of the Temple, which the possession of the Antonia afforded, would no doubt inflame the desire of the Roman commander to preserve it uninjured for himself as a splendid trophy of his victory. But the Holy House of God, though now deserted by Him for whose honour it was built, and though given over to desolation, was not to become the pride and glory of a pagan, nor could the earnest and constant endeavours of Titus preserve it from destruction.

Unwillingly, therefore, he gave orders to renew the assault upon the sacred courts; and, having selected a body of his bravest troops, committed the command of them to Cerealis, while he himself took up his station on the summit of the tower, to cheer his soldiers by his own witness of their valour. The ninth hour of the night was again chosen for the attack, as it was hoped that the guards of the Temple might be sleeping, and the gates be taken by surprise. The Jews, however, were found vigilant and alert, and, on the approach of the assailants, rushed forth to the battle with loud shouts! and another desperate affray began. The darkness, the narrowness of the place, and the impetuosity of the antagonists, rendered it soon impossible to distinguish friend from foe; and the battle became an indiscriminate slaughter, each man striking blindly at the one before him. But by and by the day broke, and then the combatants were more easily distinguished by their armour and physiognomy. Each party contended with inflexible valour, alternately encouraged and exhorted by their respective friends above and 
around them; for the combat seemed, as it were, on the arena of a theatre; overlooked on the one side by Titus himself from the turrets of the Antonia, and on the other by John from the cloisters of the Temple. Eight hours the conflict was maintained; but the Romans, though aware that the eye of Cæsar was on them, had not gained an inch of ground, and were at length compelled to relinquish their purpose.

These contests had proved, as Titus had foreseen, that, owing to the narrowness of the space between the Antonia and the Temple, a sufficiently large body of men could not be brought up, to effect the storming of that sacred fortress. He had, therefore, ordered the demolition of a portion of the Antonia, and at length, after seven days had elapsed from its capture, this was accomplished, and a broad, level area formed in front of the Holy House. On this the legions proceeded to erect embankments, though with immense labour, for the materials had to be procured at the distance of a hundred furlongs from the city. These banks, as on the former occasions, were four in number; and, notwithstanding the furious sallies of the Jews, they proceeded to their completion.

In the meantime, as if to cut off those members of the body which were infected, to prevent the distemper from spreading, the Jews themselves set fire to the cloisters that connected the Antonia with the Temple, and thus completely isolated the latter. At the same time, another beautiful portion of the sacred edifice was sacrificed to a successful stratagem. One 
of the embankments had been erected opposite the cloisters that ran along the western front. The space that was between the roof and the beams of this colonnade having been filled with pitch and other combustibles, the Jewish garrison affected to retire from the top, as if abandoning, in despair, its further defence. On this, multitudes of the Romans, as had been anticipated, eagerly applying their scaling-ladders, climbed upon the roof, till the space was covered with them. The crafty Jews then fired the mass ; and instantly, on every side, burst forth the flames, curving round, and inclosing the deluded assailants as with a wall of fire. The hissing of the manytongued flame, that leaped, and curled, and writhed about them, and the crackling of the timbers, drowned the groans and cries of the dying men, as they rushed helplessly to and fro, and vainly held out their hands to their comrades below. Many cast themselves headlong through the blaze, and were dashed to pieces; others stabbed themselves with their own swords; while some escaped from the fire to the wall of the cloister, where they were surrounded and slain by the exasperated Jews. All perished; and that in the sight of Titus, who could afford them no relief, but the solace of his pity.

By this desperate manœuvre, the whole of the western cloister was destroyed as far as the gate that led to the Xystus, and the remainder was immediately afterwards separated from the Temple. On the next day, the Romans set fire to the northern cloister, and this was destroyed through its whole 
length; even to the angle, where it was joined to the east cloister, that looked down into the profundity of the Valley of Jehoshaphat.

Thus the Romans became masters of the Court of chambers of the Court of Israel; but so mighty were the stones, and so compactly fixed, that the incessant blows had not produced the slightest impression upon them. By manual labour the foundations of the

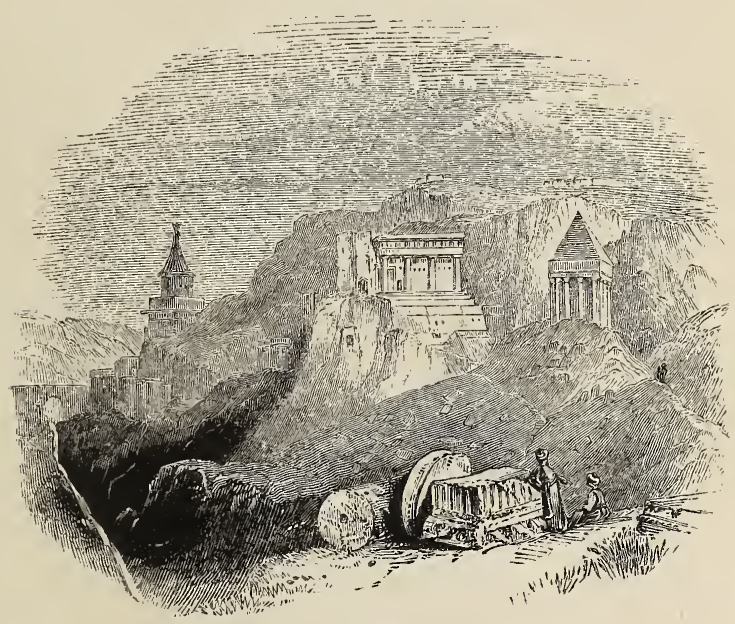

VALLEY OF JEHOSHAFHAT.

northern gate had been loosened, after herculean efforts; but the inner masonry was still so massive, that the stability of the gate was in no wise affected. Despairing of success by these means, the Romans again attempted to scale the inner cloisters. The ladders were planted and mounted without opposition; but no sooner did an assailant show his head at the 
summit, than he was hurled headlong; sometimes a ladder covered with armed men was seized at the top, and by main strength thrown down on those beneath. Sallies were made from below with the usual Jewish valour; in some of these the military engines were captured, and even the eagle-standards were with difficulty preserved.

There remained, therefore, no resource to the besiegers, but the application of fire; and this at length was reluctantly ordered by the Roman general. The legionaries at once piled faggots at the gates, and set them on fire; the silver with which the doors were covered soon becoming red hot, and igniting the wood, the flames spread with rapidity, and caught hold of the cloisters. The Jews were overwhelmed with astonishment, and made no effort to quench the fire, but gazed on it in mute despair. The whole of that day and part of the next did the conflagration go on; not, however, in one mass of spreading fire, but piecemeal, as the soldiers were able to perform the work of destruction.

On the day following, Titus held a council with his principal commanders, as to what should be done with the Holy House. Some advised. that it should be utterly demolished; but Titus himself was still disposed to preserve it if possible, for its magnificence, which "would be a perpetual ornament to the Roman dominion." Of course his opinion prevailed; and he commanded that the cohorts should at once make their way through the ruins, and quench the fire. With some difficulty this was done, and the remainder of that day was passed in inaction, as if 
by mutual consent; a brief and sullen lull in the fiery tempest.

But early the next morning the Jews made another furious assault upon the troops that were occupying the Court of the Gentiles. The Romans were overborne by the fiery valour of their opponents; but Cæsar, beholding their distress from the Antonia, sent succours of cavalry, which turned the scale. The battle raged with shifting success for three hours, when, at length, the Jews retired into the Inner Courts, and the Romans into the Antonia : Titus resolving to storm the Temple with his whole force early the next morning. His purpose, however, was forestalled.

It was now the tenth day of the month $\mathrm{Ab}$; by a wondrous coincidence, the same fatal day as that on which the glorious first Temple, the edifice raised by the piety and power of Solomon, had been burned to the ground by the king of Babylon. The Jews again attacked the soldiers who were engaged in quenching the fires, but, being repulsed, the Romans pursued them into the interior, and reached the doors of the Holy Place. A soldier, acting upon his own impulse, being lifted in the arms of one of his comrades, suddenly threw a torch into a small golden window, and the House was in flames!

A shriek of rage, despair, and consternation rent the heavens, as the devouring blaze enwrapped the Holy House. Titus heard it, and, being informed of the cause, he rushed from his tent, where he had retired to rest, and ran to the spot. He issued orders, by shouts and signs, to quench the fire; but 
none regarded him : the wildest confusion and tumult prevailed; the legionis came thronging on, each intent on gratifying his own revenge or avarice; there was no command, no obedience : in their mad and furious zeal multitudes were trampled under foot by their comrades, or fell among the hot and smoking ruins, or perished by each other's hands. The flames spread fast, for the wild and excited soldiers encouraged each other to the work of destruction.

The poor Jews seemed overwhelmed with despair : to the last they had trusted that there would be some miraculous interposition, by which the Holy House would be saved from the impending desolation; but now it was come, and their hopes withered before it. The sword dropped from their powerless hands, and they were slain by thousands, an unresisting multitude: the steps of the altar, and the surrounding area, were covered, nay heaped, with their dead bodies, while their blood ran in purple floods from the marble pavements.

The Roman general lifted the Veil, and with his commanders stood within the Holy of Holies. He was astonished at the splendour around him, which far exceeded all his expectations. The precious gold of Ophir, the rarest and most radiant gems, costly and fragrant woods, were there in richest profusion ; shaped into beauteous forms of exquisite workmanship, and consummate taste. The flames had not yet penetrated the Sanctuary, and Titus hastened out with the hope that the glorious shrine, " the Perfection of Beauty," might still be saved. Again he entreated those around him to second his 
endeavours; he gave orders to his centurions to beat off the rebellious soldiers; but all was of no avail. A decree higher than Cæsar's had gone forth, and who could disannul it?

The sight of the massy gold and glittering stones, that reflected the light of the flickering flames, more and more excited the tumultuous legions; and while Titus was anxiously beseeching them to spare the edifice, a soldier, unperceived, thrust a firebrand between the hinges of the golden door, and threw it into the dark interior. Immediately the whole was filled with flame, which burst forth so impetuously, that the commanders were compelled to flee before it, and abandon the House to its destruction.

Immense was the multitude of the slain: the whole summit of Mount Moriah was seething-hot, yet the blood was more than the fire, and the slain more numerous than the slayers; the ground was nowhere visible because of the bodies that lay on it, and the slaughter was prosecuted over heaps of corpses. Of the mighty and magnificent Temple there remained only two gates, and a portion of the outer cloisters, on which six thousand trembling fugitives had taken refuge, chiefly women and children. These were wantonly murdered in cold blood, the soldiers setting fire to their refuge: not one escaped.

And now for the "holy and beautiful House," the "joy of the whole earth," that had covered, as with a crown, the glory of the summit of Moriah, there lay only a shapeless and blackened ruin, from whose 
heaps sullen clouds of smoke and ashes ever and anon ascended, telling of the demon of destruction, that had done his fatal work. And as if to perfect the desecration of the once hallowed spot, and to show how utterly Jehovah had forsaken it, the legions paraded their idol-ensigns over the desolate surface, and setting them up against what had been the eastern gate, "the Beautiful Gate of the Temple," offered sacrifice and burnt incense to the devilgods, * whom they represented.

$\mathrm{O}$ GOD, why hast thou cast us off for ever? why doth thine anger smoke against the sheep of thy pasture?

Remember thy congregation, which thou hast purchased of old; the rod of thine inheritance, which thou hast redeemed; this mount Sion wherein thou hast dwelt.

Lift up thy feet unto the perpetual desolations; even all that the enemy hath done wickedly in the sanctuary.

Thine enemies roar in the midst of thy congregations; they set up their ensigns for signs.

A man was famous according as he had lifted up axes upon the thick trees.

But now they break down the carved work thereof at once with axes and hammers.

They have cast fire into thy sanctuary; they have defiled by casting down the dwelling-place of thy name to the ground. Ps. lxxiv. 1-7.

Bezetha had fallen, Acra had fallen, the Antonia had fallen, the Temple had fallen; but the strong City of David still remained. The daughter of Zion was left, indeed, "as a cottage in a vineyard, as a lodge in a garden of cucumbers, as a besieged city;" but her towers were mighty, herwalls massive, and her heights scarcely accessible; and if her God and King had been still in the midst of her, as of old, she might 
have looked down from her impregnable position on the beleaguering army, and laughed it to scorn.

Simon and John, with many of their adherents, had retired into the Upper City, on the burning of the Temple, and now demanded a parley with Titus across the bridge that spanned the Tyropœon. He required, however, an unconditional surrender, to which they would not accede; whereon he, in anger, determined to give no further quarter, but to put to death, without mercy, all who fell into his hands. The next day he delivered up the Lower City to be plundered and burned by his soldiers. Acra, with the archives, the council-house, and the palace of Helena, was at once set on fire, as well as the quarter called Ophel.

The sides of the Tyropœon, which is now, owing to the accumulation of ruins and the débris of ages, but an unimportant depression, were then so abrupt and deep, that Titus had no hope of storming the wall of Zion without the slow and painful process of raising embankments for the support of the engines of war. But the extreme scarcity of timber, as before, presented a great difficulty; as it had to be conveyed from a long distance. About four weeks were occupied in the construction of these banks, which at length were reared, one opposite the Royal Palace, near the west angle of the wall, the other opposite the Xystus, near the Temple-bridge.

At this time the Idumeans entered into secret negotiations with Titus for surrendering themselves to him. The terms were agreed on, and that important body of valiant men were on the point of 
marching out, when the vigilant Simon, obtaining intelligence of it, arrested the leaders, and placed the multitude under strict surveillance. Great numbers, however, deserted every day: the unarmed populace were spared; but all the rest were sold as slaves, the number of whom was immense.

At length some of the towers gave way before the blows of the battering-rams, and the Romans prepared to mount the breach. Experience had well taught them how to estimate the peril of storming a Jewish wall; and they were expecting now, as before, to be met with the sternest valour and the most heroic resolution. But the courage of the Zealot leaders had utterly forsaken them; the rumour that the Romans were approaching scattered them like frighted sheep; some fell upon their faces with wailing and lamentation, others sought refuge in wells and subterranean passages, while Simon and John, instead of remaining in the towers, which no engines could have overthrown, fled towards the Pool of Siloam, and endeavoured to burst through the Roman trenches. But their unwonted timidity rendered them powerless; they were easily repulsed by the guards, and fled to the caverns that lay beneath the city.

The Romans finding themselves unopposed where they expected a strenuous resistance, joyfully took possession of the city; and thus Jerusalem was at length wholly subdued. But the cessation of resistance moved not their iron hearts to mercy: they poured through the streets and lanes, sword in hand; slaying man, woman, and child; the houses, 
where many poor fugitives had crowded together, were fired, and every soul was burned to death. They were horrified by finding large buildings full of the dead; but this sight did not produce any com-

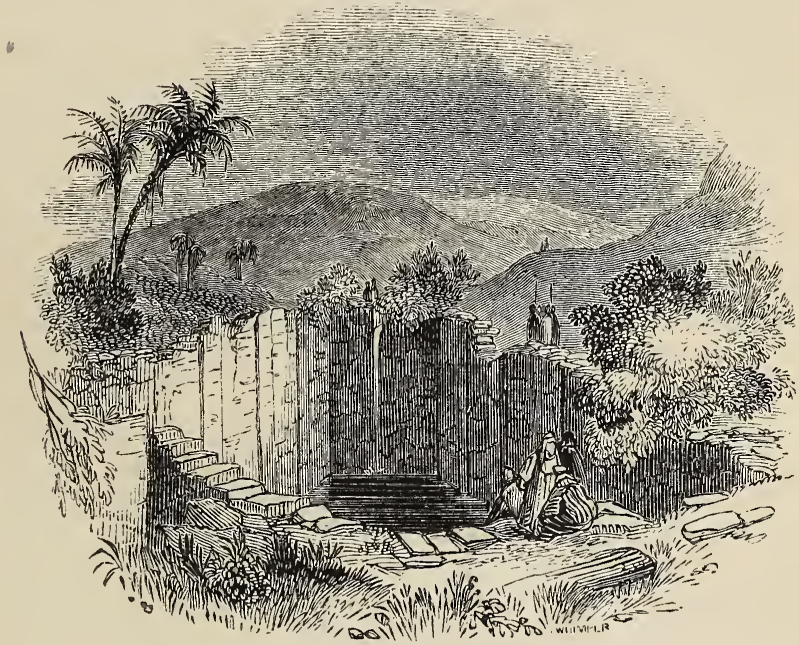

POOL OF SILOAM.

miseration for the living: every one whom they met they ran through, and made the steep streets so to run down with blood, that, as is gravely asserted, the fire of some of the burning houses was actually quenched with it.

How is the gold become dim! how is the most fine gold changed! the stones of the sanctuary are poured out in the top of every street.

The precious sons of Zion, comparable to fine gold, how are they esteemed as earthen pitchers, the work of the hands of the potter!

Even the sea-monsters draw out the breast, they give suck to their young ones: the daughter of my people is become cruel, like the ostriches in the wilderness. 
The tongue of the sucking child cleaveth to the roof of his mouth for thirst; the young children ask bread, and no man breaketh it unto them.

They that did feed delicately are desolate in the streets; they that were brought up in scarlet embrace dunghills:

For the punishment of the iniquity of the daughter of my people is greater than the punishment of the sin of Sodom, that was overthrown as in a moment, and no hands stayed on her.

Her Nazarites were purer than snow, they were whiter than milk, they were more ruddy in body than rubies, their polishing was of sapphire :

Their visage is blacker than a coal; they are not known in the streets: their skin cleaveth to their bones; it is withered, it is become like a stick.

They that be slain with the sword are better than they that be slain with hunger: for these pine away, stricken through for want of the fruits of the field.

The hands of the pitiful women have sodden their own children, they were their meat in the destruction of the daughter of my people.

The Lord hath accomplished his fury; he hath poured out his fierce anger, and hath kindled a fire in Zion, and it hath devoured the foundations thereof.

The kings of the earth, and all the inhabitants of the world, would not have believed that the adversary and the enemy should have entered into the gates of Jerusalem.

For the sins of her prophets, and the iniquities of her priests, that have shed the blood of the just in the midst of her,

They have wandered as blind men in the streets, they polluted themselves with blood, so that men could not touch their garments. Lam. iv. 1-14.
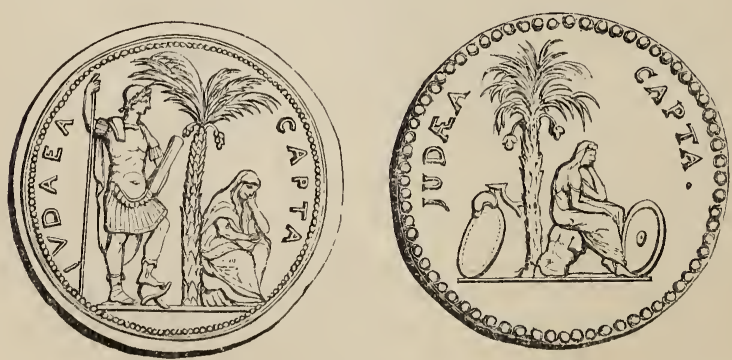

ROMAN MEDALS. 


\section{CHAPTER IX.}

\section{THE DESOLATION.}

\section{A. D. 70 .}

Walk about Zion, and go round about her: tell the towers thereof: mark ye well her bulwarks, consider her palaces; that ye may tell it to the generation following. Ps. xlviii. 12, 13.

Titus was now undisputed master of Jerusalem: and as he walked through the magnificent streets of the Upper City, and gazed upon the solid walls, and massive towers, with which it was defended, and noticed the enormous magnitude of the stones, and the strength of the masonry, - he is said to have been lost in admiration. "Of a surety," said he, "God has been our assistant in this siege; none but God has ejected the Jews from these fortifications; for of what avail could all the strength of man, or of machines have been, in overthrowing such towers as these!" And when the city was demolished, three of these towers were left standing, to "tell to generations following," what a city that was that he had besieged and taken.

The army was now glutted and wearied with slaughter; and yet there remained a vast multitude of wretched creatures, of whom it was difficult to 
dispose. Of these, however, the aged and infirm were ordered to be slain, as well as all those who had been taken in arms : the rest were driven, a hapless throng, within the bare and blackened walls of the Temple courts, where one Fronto was deputed to adjudicate upon their fate. All who were accused by one another of having been factious were slain; the tallest and most beautiful young men were reserved to grace the triumph of the conqueror; an immense number were distributed into the provinces, to be destroyed in the theatres and public shows, by sword-combats or by wild beasts; all who were under seventeen years old were sold for slaves; and all above that age were chained and sent to work in the Egyptian mines. To enhance the misery of their condition, it is recorded that during the few days that this adjudication was proceeding, there died of the number no less than eleven thousand from want of food!

The Jews who perished in this terrible visitation of Jerusalem are said to have amounted to the almost incredible number of one million one hundred thousand, while ninety-seven thousand were carried into captivity. These were from Jerusalem alone, without including those who perished before the siege began, or in the sanguinary progress of the Roman army in Galilee, in Samaria, in Peræa, and in other parts of Judea. The whole multitude destroyed in the seven years' war is computed, from Josephus's numbers, at one million, three hundred and fifty-six thousand, four hundred and sixty!

Thus terrible in its beginnings was the "ven- 
geance," and the "tribulation" which then fell upon the Jewish people, in conformity with the memorable prediction of their rejected Messiah. It then began, and has been pursuing and crushing them ever since through near two thousand years, though with merciful mitigations or "shortenings :" nor are these days of vengeance yet come to an end.

And as some spake of the temple, how it was adorned with goodly stones and gifts, he said, As for these things which ye behold, the days will come, in the which there shall not be left one stone upon another, that shall not be thrown down.

Then said he unto them, Nation shall rise against nation, and kingdom against kingdom: and great earthquakes shall be in divers places, and famines, and pestilences ; and fearful sights and great signs shall there be from heaven.

And many false prophets shall rise, and shall deceive many. .

And when ye shall see Jerusalem compassed with armies, then know that the desolation thereof is nigh. Then let them which are in Judea flee to the mountains; and let them which are in the midst of it depart out; and let not them that are in the countries enter thereinto. For these be the days of vengeance, that all things which are written may be fulfilled. But woe unto them that are with child, and to them that give suck, in those days! for there shall be great distress in the land, and wrath upon this people. And they shall fall by the edge of the sword, and shall be led away captive into all nations: and Jerusalem shall be trodden down of the Gentiles, until the times of the Gentiles be fulfilled.

For then shall be great tribulation, such as was not since the beginning of the world to this time, no, nor ever shall be. And except those days should be shortened, there should no flesh be saved: but for the elect's sake those days shall be shortened. Matt. xxiv. and Luke xxi.

There is one prediction in this passage which deserves especial notice: the "fearful sights and great signs from heaven," which should accompany the fall of the guilty city. When we remember the character of Him who foretold these signs, we are 
sure that no jot nor tittle of His words could fail; nor will we so dishoriour our blessed LoRD as to attempt, as some have done, to explain away the marvellous prodigies which fulfilled His word, or to insinuate that they were natural phenomena; but rather rejoice that they have been recorded by one whom we cannot suspect of any design to corroborate this Divine Prophecy.

Thus there were many false prophets, who deluded the people with assurances of miraculous help, even to the very extremity; on the very day that the Temple was burnt one of these visionaries had made public proclamation, as if from God, that deliverance should be granted by a miracle, commanding the populace to assemble at the Holy House. Multitudes, believing the assurance, congregated there, and were slain by the Romans.

A star, or comet, in the form of a sword, is said to have hung over the city through a whole year. Before the breaking out of the war, when the people were assembled at the Passover, on the eighth day of Nisan, there suddenly appeared a light shining round the altar, that was as bright as day, though it was the ninth hour of the night; and this light continued for half an hour. At the same festival a heifer, as she was led forth to be sacrificed, brought forth a lamb in the midst of the Temple.

At another time " the eastern gate of the Inner Court, which was of brass, and vastly heavy, and had been with difficulty shut by twenty men, and rested on a base armed with iron, and was furnished with bolts, fastened very deep into the firm floor, which 
was there made of one entire stone, was seen to open of its own accord about midnight. The populace thought this a happy omen, but the scribes expounded it to prognosticate that the sacredness and security of the Holy House were about to be dissolved.

And still more significant were the voices heard by the Priests at the feast of Pentecost. Going in at night to perform the accustomed service, they felt a great quaking, and heard a noise, followed by the sound as of a multitude of footsteps, and voices saying, "Let us depart hence."

Again, on the twenty-first day of the month Jyar, there appeared in the sky "a prodigious and incredible phenomenon;" for in the afternoon, a little before sunset, there were seen, in the clouds, chariots and horsemen performing military manœuvres, and the visionary storming of a city.

Nor was there wanting more distinct and oral monition of the coming desolation. At the feast of Tabernacles, seven years before the overthrow, a rustic named Jesus, the son of Ananus, began to cry against the city and temple; and through the whole of her remaining existence the streets of Jerusalem never ceased to echo his boding voice. Day and night he passed on his solitary way, noticing none, neither those that beat him nor those that gave him food; but ever uttered his melancholy "Woe to Jerusalem!" "A voice from the east, a voice from the. west, a voice from the four winds, a voice against Jerusalem and the Holy House, a voice against the bridegroom and the bride, a voice against this whole people!" He was arrested and severely 
punished by the elders, but he did not intermit his prophetic cry; he was brought before the Procurator, and scourged till his bones were exposed, yet he made no supplication, nor shed a tear, but cried at every stroke, "Woe to Jerusalem !" At length the Romans came, and the city was shut up, and the engines began to beat upon the tottering wall; still the son of Ananus strode through the deathstruck streets, and flung forth his ceaseless "Woe." But now his message approached its end; and as he went his round upon the walls, he stopped, and with more than usual energy gave utterance to his last denunciation; "Woe to the city, and to the people, and to the Holy House! And now, woe to myself!" At the instant the word left his lips, a huge stone from the mighty catapult smote him with a thundering sound, and, dashing him to pieces, put an end to his life and to his prophecy.

It appears unaccountable that a resistance so hopeless should have been prolonged to the very last extremity; but the people seemed utterly incapable of entertaining the idea of Jehovah's desertion of his City and Temple. The solemn threatenings of His prophets they had either despised or neglected, and trusted in the favour of God through their natural relation to Abraham, though His holy name through their iniquities was blasphemed among the Gentiles. Nor were there wanting (as we have already intimated) prophets who confirmed them in this their presumptuous confidence; "false prophets who prophesied lies" in the name of Jehovah; and caused the judicially 
blinded people to trust in "a refuge of lies;" to the very last these were numerous in Jerusalem, who, in the lofty language and burning imagery of the inspired Scriptures, continually flung out proud denunciations of wrath about to fall upon the invader, and announced the miraculous interposition of God to save His Temple in the very moment of extremity. Alas! alas! the builders had proudly rejected the "Chief Corner-stone, ELECT, PRECIOUs," on whose sure foundation they might have been established and preserved for evermore; and now the overflowing scourge was come, and was sweeping away their refuge of lies, and destroying their deceitful hiding-place, even as they had been warned long before.

Wherefore hear the word of the LorD, ye scornful men, that rule this people which is in Jerusalem: Because ye have said, We have made a covenant with death, and with hell are we at agreement; when the overflowing scourge shall pass through, it shall not corne unto us : for we have made lies our refuge, and under falsehood have we hid ourselves: Therefore thus saith the Lord God, Behold, I lay in Zion for a foundation a stone, a tried stone, a precious corner-stone, a sure foundation: he that believeth shall not make haste. Judgment also will I lay to the line, and righteousness to the plummet; and the hail shall sweep away the refuge of lies, and the waters shall overflow the hidng-place. And your covenant with death shall be disannulled, and your agreement with hell shall not stand; when the overflowing scourge shall pass through, then ye shall be trodden down by it. From the time that it goeth forth it shall take you : for morning by morning shall it pass over, by day and by night; and it shall be a vexation only to understand the report. For the bed is shorter than that a man can stretch himself on it; and the covering narrower than that he can wrap himself in it. For the Lorn shall rise up as in Mount Perazim, he shall be wroth as in the valley of Gibeon, that he may do his work, his strange work; and bring to pass his act, his strange act. Now, therefore, be ye not mockers, lest your bands be made strong : for I have heard from the LoRD God of hosts a consumption, even determined upon the whole earth. Isa. xxviii. 14-22. 
In conformity with the prediction of the Lord Jesus, that of the magnificent buildings of the Temple "not one stone should be left upon another," Titus issued orders that the entire city and Temple should be demolished, with the exception of three

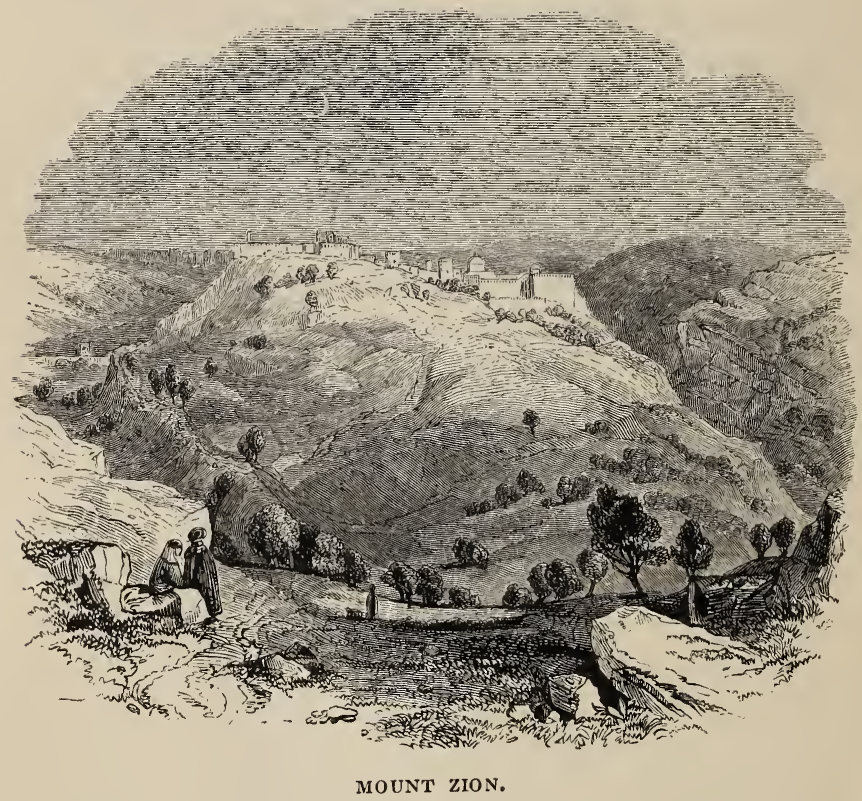

towers in Zion, and part of the western wall, which were spared to afford a shelter to the garrison whom he intended to leave. So well did the soldiers perform their work, that the city was "dug up to its foundations, so that there was left nothing to make those who came thither believe it had ever been inhabited." 
Therefore shall Zion for your sake be plowed as a field; and Jerusalem shall become heaps; and the mountain of the House as the high places of the forest. Mic. iii. 12.

Thus fell Jerusalem, the City of the great King : and Titus having sacrificed to his senseless idols, and ascribed to them the success for which he had been raised up by the Living God, and having distributed rewards and spoils in profusion to his army, departed from the desolate scene to Cæsarea, leaving the tenth legion as a garrison over the ruins. Thence he made a triumphal progress through the cities of Syria, his steps everywhere marked by the blood of the poor captive Jews, "poured out like water." For wherever the imperial savage came, thousands of his prisoners were tortured in a thousand different ways; slain in cold blood, made to fight as gladiators with each other, or thrown to lions and tigers in the amphitheatres, - for the amusement of the populace. Such was the mercy of one, whom it has been the fashion to call clement, the delight of the human race, \&c. His apostate flatterer has done his best to hide the darker features of his character; but the facts that even he has recorded enable us to discover that, whatever he might be to others, in the fold of Judah he ravened as a wolf; in the heritage of God, given over into his hand, he was indeed "a beast dreadful and terrible, and strong exceedingly, that devoured, brake in pieces, and stamped the residue with his feet."

We naturally feel an interest in the fate of the renowned leaders, John of Gischala, and Simon the 
son of Gioras. The former, pressed by famine in the caverns to which he had retired, surrendered to the Romans, and was condemned to perpetual imprisonment. The latter struggled more fiercely with his fate. He took with him into the caverns a number of his adherents, with implements for mining, and a stock of provisions, hoping to be able to excavate a passage for himself through the base of the mountain. He found this, however, a hopeless task; and after the departure of Titus he suddenly appeared like a spectre rising out of the ground, clothed in a white robe, over which was thrown a purple cloak. The Roman soldiery were awed at first at the apparition, but soon apprehended him, when he demanded to see their commander. On being brought before Terentius Rufus, the captain of the legion, he declared his name and quality; and was then conveyed to Cæsarea to await the pleasure of Titus.

The appearance of these terrible leaders, the very impersonation of the insurrection, out of the subterranean caverns, speaking in unwonted tones of humility and abject submission "out of the ground," seems to be a very striking accomplishment of a prophecy, many of the terms of which manifestly assign its application to the siege and desolation which we are now narrating.

Woe to Ariel, to Ariel, the city where David dwelt! Add ye year to year; let them kill sacrifices. Yet I will distress Ariel, and there shall be heaviness and sorrow: and it shall be unto me as Ariel. And I will camp against thee round about, and will lay siege against thee with a mount, and I will raise forts against thee. And thou shalt be brought down, and shalt speak out of the ground, and thy speech shall be low out 
of the dust, and thy voice shall be, as of one that hath a familiar spirit, out of the ground, and thy speech shall whisper out of the dust. Moreover the multitude of thy strangers shall be like small dust, and the multitude of the terrible ones shall be as chaff that passeth away: yea, it shall be at an instant suddenly. Thou shalt be visited of the Lord of hosts with thunder, and with earthquake, and great noise, with storm and tempest, and the flame of devouring fire. Isa. xxix. 1-6.

We shall not describe the pompous pageant which accompanied Vespasian and Titus on their triumphal entry into Rome. All that could aggrandize Rome

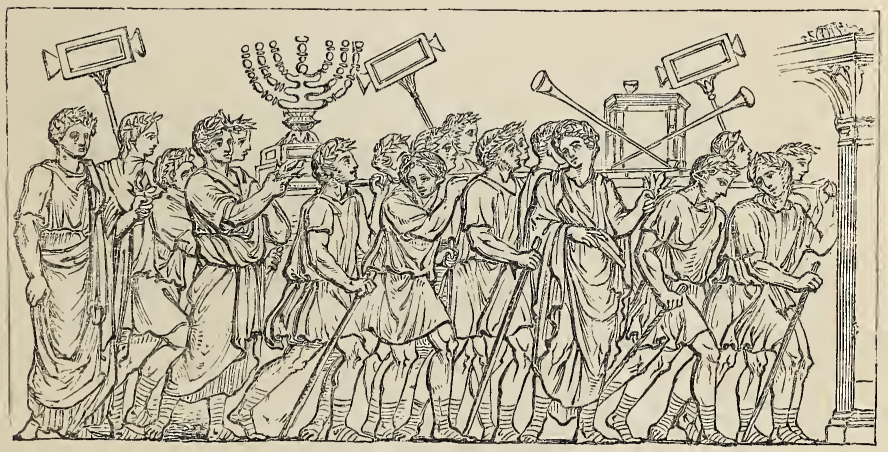

SPOILS OF THE TEMPLE.

and its idol demons, all that could dishonour the broken people of Israel and Jehovah, was here accumulated in a gorgeous show, which Josephus, apostate as he was, could describe without an expression of sympathy for his bleeding country, without a tear of sorrow for his trampled people, or a word of disapprobation at the insults offered to his God. Among the spoils were the golden table of the shewbread, and the seven-branched candlestick of gold, that had been snatched from the sanctuary of 
God; and after these was carried the copy of the Law, wrapped in its splendid coverings; a trophy whose preciousness, greater than that of gold and silver, they who carried it little knew how to appreciate. The unhappy son of Gioras was led in chains at the chariot wheels of the victors; he was led to the Forum, inhumanly tortured as he was dragged along, and there at length slain. Thus fell one who, whatever his crimes (and we must remember that they are narrated by one whose interest it was to blacken the portrait), at least identified the fate of Jerusalem with his own, devoted his utmost energies to her defence, and died for her sake; scorning to purchase, like his renegade biographer, his own ease and safety at the price of his national faith.

On the very spot where this cruel execution was perpetrated, a triumphal arch was erected, which has survived to this day. Among the sculptured bas-reliefs, with which this "Arch of Titus" is adorned, we may still trace with peculiar interest the record of the gorgeous ovation. There is the candlestick with its seven sconces, the table, the silver trumpets, and other furniture of the spoiled Temple; and then marches the procession of melancholy captives, bearing aloft upon their shoulders their own most precious things.

The reduction of two or three strong, but unimportant mountain fortresses in Judea, where the Jews sternly maintained their resistance to Rome, occupied two or three years. At length all was over; and the now desolate land, once the Lord's he- 
ritage, was let out to hire as the private property of the emperor. And now let us take our stand among the deserted ruins of Jerusalem, and view the scene where the Lord "hath thrown down in His wrath the strongholds of the Daughter of Judah." And

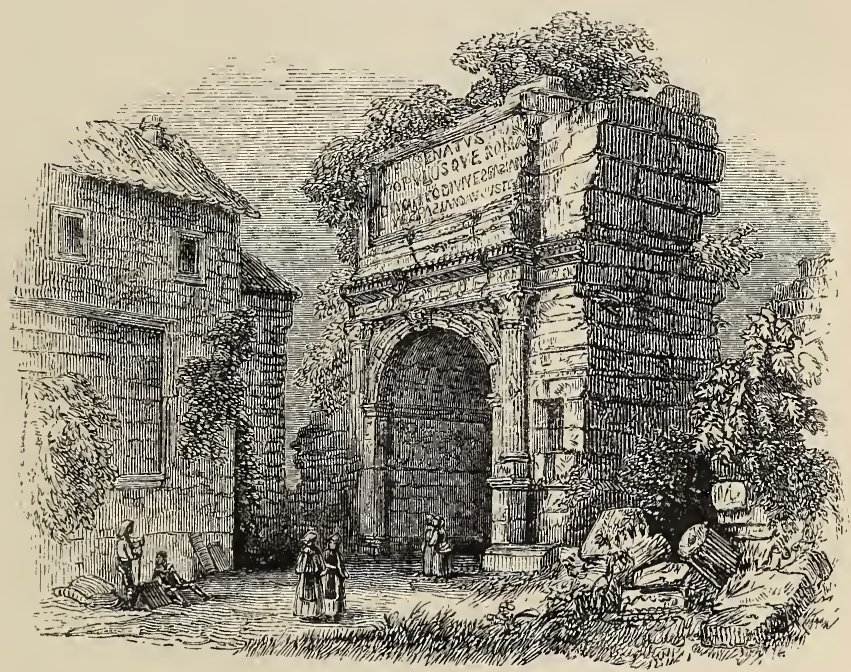

ARCH OF TITUS.

in bringing before us the melancholy picture, we cannot refrain from using the words of Jeremiah.

How doth the city sit solitary that was full of people! how is she become as a widow! she that was great among the nations, and princess among the provinces, how is she become tributary!

She weepeth sore in the night, and her tears are on her cheeks; among all her lovers she hath none to comfort her: all her friends have dealt treacherously with her; they are become her enemies.

Judah is gone into captivity, because of affliction, and because of great servitude; she dwelleth among the heather, she findeth no rest: all her persecutors overtook her between the straits. 
The ways of Zion do mourn, because none come to the solemn feasts: all her gates are desolate; her priests sigh, her virgins are afflicted, and she is in bitterness.

Her adversaries are the chief, her enemies prosper; for the LoRD hath afflicted her for the multitude of her transgressions: her children are gone into captivity before the enemy.

And from the daughter of Zion all her beauty is departed: her princes are become like harts that find no pasture; and they are gone without strength before the pursuer.

How hath the LoRD covered the daughter of Zion with a cloud in his anger, and cast down from heaven unto the earth the beauty of Israel, and remembered not his footstool in the day of his anger!

The Lord hath swallowed up all the habitations of Jacob, and hath not pitied: he hath thrown down in his wrath the strongholds of the daughter of Judah; he hath brought them down to the ground: he hath polluted the kingdom and the princes thereof.

He hath cut off in his fierce anger all the horn of Israel : he hath drawn back his right hand from before the enemy, and he burned against Jacob like a flaming fire, which devoureth round about.

He hath bent his bow like an enemy: he stood with his right hand as an adversary, and slew all that were pleasant to the eye in the tabernacle of the daughter of Zion: he poured out his fury like fire.

The LorD was as an enemy; he hath swallowed up Israel, he hath swallowed up all her palaces; he hath destroyed his strongholds, and hath increased in the daughter of Judah mourning and lamentation.

And he hath violently taken away his tabernacle, as if it were of a garden; he hath destroyed his places of the assembly: the LORD hath caused the solemn feasts and sabbaths to be forgotten in Zion, and hath despised, in the indignation of his anger, the king and the priest.

The Lor $\mathrm{D}$ hath cast off his altar, he hath abhorred his sanctuary, he hath given up into the hand of the enemy the walls of her palaces; they have made a noise in the house of the LorD, as in the day of a solemn feast.

The LorD hath purposed to destroy the wall of the daughter of Zion; he hath stretched out a line, he hath not withdrawn his hand from destroying: therefore he made the rampart and the wall to lament; they languished together.

Her gates are sunk into the ground; he hath destroyed and broken her bars; her king and her princes are among the Gentiles: the law is no more; her prophets also find no vision from the LonD.

The elders of the daughter of Zion sit upon the ground, and keep 
silence: they have cast up dust upon their heads; they have girded themselves with sackcloth: the virgins of Jerusalem hang down their heads to the ground.

Mine eyes do fail with tears, my bowels are troubled, my liver is poured upon the earth, for the destruction of the daughter of my people; because the children and the sucklings swoon in the streets of the city.

They say to their mothers, Where is corn and wine? when they swooned as the wounded in the streets of the city, when their soul was poured out into their mothers' bosom.

What thing shall I take to witness for thee? what thing shall I liken to thee, $\mathrm{O}$ daughter of Jerusalem? what shall I equal to thee, that I may comfort thee, $\mathrm{O}$ virgin daughter of Zion? for thy breach is great like the sea: who can heal thee?

Thy prophets have seen vain and foolish things for thee: and they have not discovered thine iniquity, to turn away thy captivity; but have seen for thee false burdens and causes of banishment.

All that pass by clap their hands at thee; they hiss and wag their head at the daughter of Jerusalem, saying, Is this the city that men call The perfection of beauty, The joy of the whole earth?

All thine enemies have opened their mouth against thee: they hiss and gnash the teeth: they say, We have swallowed her up: certainly this is the day that we looked for; we have found, we have seen it.

The Lor b hath done that which he had devised; he hath fulfilled his word that he had commanded in the days of old: he hath thrown down, and hath not pitied: and he hath caused thine enemy to rejoice over thee, and hath set up the horn of thine adversaries. Lam.i. ii.
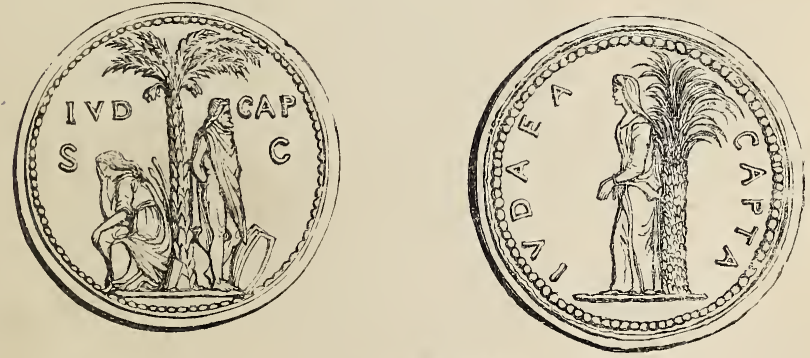

ROMAN MEDALS. 


\section{CHAPTER X.}

A. D. $70-136$.

REVOLTS UNDER TRAJAN AND ADRIAN.

Jerusalem was now become "heaps," and the Mountain of the Lord's House was "as the high places of a forest;" hope itself had perished in the fall of the Temple, and lay buried beneath the desolate ruin. Yet, in the sullenness of utter desperation, resistance was still prolonged; and three strong fortresses in the rocky region of the Dead Sea afforded a temporary respite to a few thousands of hopeless Jews. To crush this last remnant of resistance to Roman supremacy, Lucilius Bassus was sent into Judea in the year after the reduction of Jerusalem. The first fortress, Herodium, was soon taken; and though the others, Machærus and Masada, from the great strength of their position, on the summit of perpendicular precipices, seemed to bid defiance to a besieging army, yet they soon fell into the hands of the Roman general. The garrison of Machærus capitulated in order to save the life of one of their leaders who had been taken captive in a sally; and that of Masada, after watching the gradual elevation of the 
enemy's embankment to the height of four hundred and fifty feet, perished by their own swords, leaving only a silent necropolis to become the prey of the conquerors.

Contrary to the usual custom of the Romans on the subjugation of a foreign country, the emperor Vespasian did not rebuild the cities of Judea that had been laid waste, nor did he permit the conquered people to inhabit their own land. The latter he ordered to be sold in lots to the highest bidders, enriching his privy purse with the proceeds; nor was any part of the country exempted from this indignity, save the village of Emmaus, near Jerusalem, which was bestowed upon the eight hundred Roman soldiers, to whom was assigned the duty of garrisoning the ruins of the desolated city.

To add to the sufferings of the prostrate people of Israel, the emperor imposed on them a tax, which wounded in the most insulting manner their religious feelings. A tribute of two drachmas, or half a shekel, had been always paid by every adult Jew, * from the earliest times; and the money had been appropriated to the service of the Tabernacle and of the Temple. This sum Vespasian ordered to be still collected, and to be applied to a purpose abhorrent to every Jew, - the rebuilding of the Temple of Jupiter Capitolinus, the most magnificent idolshrine in Rome, which had been lately burned. The detestable tax was levied throughout the Empire with inexorable tyranny: nor was it repealed even after its ostensible purpose had been completed

* See Matt. xvii. 24; and Exod. xxx. 12-16. 
in the restoration of the Roman Temple; for we find it in existence in the time of Origen.

For nearly sixty years after the tide of desolation had flowed over the land of Judea we know little of its history. As the first jealousy which watched the blackened heaps on Moriah and Zion began to abate its sleeplessness, individuals and families would doubtless wander back to seek a shelter in the spot endeared by memories both glorious and sorrowful, or to lay their bones in the tombs of their fathers. When the emperor Adrian visited Jerusalem, about fifty years after its destruction, (if Epiphanius's date is correct, ) he found a small Christian Church assembling at the Conaculum, or House of the Last Supper, on Mount Zion, and occupying a few houses in the vicinity; while of Jews there were seven synagogues not far from that hallowed spot, one of which remained even down to the time of Constantine.

But these intruders, few and feeble as they must have been, were watched with the severe scrutiny of imperial suspicion. Strict search had been made by Vespasian for all who claimed affinity to the royal house and lineage of David, that they might be put to death. The jealous Domitian revived the odious inquiry; and a Christian historian has recorded an incident of singular interest, to which it gave rise. Two individuals, accused of being descended from the royal ${ }^{\prime}$ line, were brought before the emperor, or more probably before his representative, the procurator of Judea. They made no secret of their lineage, for they were the grandsons of the venerable A postle Jude, the brother of the Lord; but the sim- 
plicity of their answers, the humility of their demeanour, and the homeliness of their garb, disarmed all suspicion even in their judge. They spoke, indeed, of the kingdom of Christ, but shewed that its character was not such as to excite the fears of the Roman emperor; and their horny hands confirmed their declaration, that their earthly subsistence was derived from their daily toil, to which they were dismissed unpunished, with mingled pity and contempt.*

The persecution of the Christians by this cruel emperor, which occurred in the fifteenth year of his reign (A.D. 95), was directed no less strongly against the Jews. The former were popularly considered as a Jewish sect; and both were confounded in the common charge of impiety and atheism, because they rejected with abhorrence the myriad idols of the Pagan world. Dio states that many Jews were condemned to death, to exile, or to the confiscation of their property, on this odious accusation; and Suetonius ascribes these proscriptions to the avarice, no less than to the cruelty, of Domitian.

Under the mild administration of the virtuous Nerva, who assumed the purple in A.D. 96, the Jews were treated with less of rigour. Those who lay in prison under the charge of impiety were discharged, and those who were banished were recalled. Persecution under such a pretext was prohibited. Many burdensome impositions, by which the Jews had been oppressed, were remitted. A medal of this emperor, inscribed "CALUmNia Fisci JudAici subLATA," has been supposed to imply the abolition of

* Euseb. iii. 20. 
the capitation-tax of the half-shekel; but as Origen expressly asserts the continuance of that impost to his time, the inscription can mean no more than that the Jews were no longer "calumniated," - that is, they were no longer, as in the reign of Domitian, fined in heavy sums on false or frivolous charges.

During the greater part of the reign of Trajan, a period of about eighteen years - we find little recorded of this people. The Jewish legend, that Rabbi Joshua was in such favour at the emperor's court, that permission was granted him to rebuild the Temple,* seems to indicate at least that they were not actively oppressed. But such a transient gleam of sunshine could but little irradiate the gloom of that tribulation under which the whole nation, "scattered and peeled," was brooding. The same traditions speak in sorrowful terms of sufferings endured during this melancholy period; and

* The narrative, however, in its sequel, shews how precarious this sort of favour was felt to be. "The Jews eagerly made preparations for the work; but it was represented to Trajan that they would revolt, and refuse to pay tribute, if allowed to re-establish themselves in such an advantageous situation as Jerusalem. Trajan, unwilling to recall his orders, asked the advice of his counsellors: they replied, that he must direct the building to be made nine feet longer or shorter than the former temple. The Jews were assembled at Rhumon. When this order reached them they were thrown into consternation, and had recourse to Joshua, the son of Chanania, whose profound wisdom was universally acknowledged. $\mathrm{He}$ related to them the apologue of the lion who was tortured, while devouring his prey, by a bone which he could not swallow. The animals were summoned to his aid with promises of a great reward; but when the stork had extracted the bone, and claimed the reward, the lion answered, 'You are fortunate to escape uninjured from my jaws.' The application was readily made. 'We are fortunate,' said Joshua, 'in living peaceably among this heathen nation, and we must be contented." - BASNAGE. 
we cannot doubt that a highminded and brave people would chafe in bitterness of heart under the pressure of so overwhelming a calamity as had recently befallen them. The contempt in which they were universally held, and which was never concealed, would be no less intolerable than the severities of tyranny; and we cannot wonder that they should watch for an opportunity of rising in arms against their oppressors. That opportunity seemed to have arrived in the eighteenth year of Trajan, when the Parthian war having in some measure drawn off the military resources of the empire to the East, the African provinces were left, in all probability, comparatively unprotected; and the Jews rose in arms. Nothing but the blind and unreasoning madness of desperation could have prompted their insurrection; for it was a rising single-handed against the power of the world. And if, with the advantage of their own land, with its mountain fastnesses and strongholds, its walled cities and military resources, commanded by able generals, and, above all, animated by the unbounded enthusiasm inspired by the presence of the Temple, they had been unable to withstand the martial power of Rome, how could they hope to succeed now, dispersed and minished, in exile, their spirits broken by oppression, their land desolate, their cities dismantled, their Temple in ruins? Yet such was the fury with which they endeavoured to throw off the Roman yoke, that they maintained a desperate, and for some time a successful, resistance to the forces which were brought against them; nor could this 
insurrection be suppressed until the slaughter on both sides had been immense,-a waste of human life scarcely less vast than that which had attended the conquest and desolation of Judea itself.

In these frantic attempts to shake off the chain which irresistibly bound them, how forcibly are we reminded of the comparison which Holy Writ had applied to them, "A wild bull in a net!"

O Jerusalem, which hast drunk at the hand of the LoRn the cup of his fury; thou hast drunken the dregs of the cup of trembling, and wrung them out. There is none to guide her among all the sons whom she hath brought forth; neither is there any that taketh her by the hand of all the sons that she hath brought up. These two things are come unto thee; who shall be sorry for thee?-desolation, and destruction, and the famine, and the sword: by whom shall I comfort thee? Thy sons have fainted, they lie at the head of all the streets, as a wild bull in a net: they are full of the fury of the LorD, the rebuke of thy God.

It was at Cyrene, a city of Libya, that the flame of insurrection suddenly burst forth. Here the Jews had been numerous and powerful for many centuries, as they had been also in the contiguous country of Egypt. The immediate occasion of the outbreak is not recorded, but we may well suppose the existence here of the same jealousy and animosity between the Jewish and Greek inhabitants, that always burned in other cities, where the rival races were nearly equal in power, wealth, or numbers. Whatever the immediate cause of the conflict, it seems to have blazed out simultaneously, through all "Egypt and the parts of Libya about Cyrene," and hence affords some ground for conjecturing that it may have been the consummation of a long-purposed, well-organised, and wide-spread conspiracy. 
The Jews had some advantages at first over the Greeks; but the latter, retiring into Alexandria, excited their countrymen in that great and populous city to rise against the Jewish population, the whole of whom were massacred. The Cyrenean Jews were

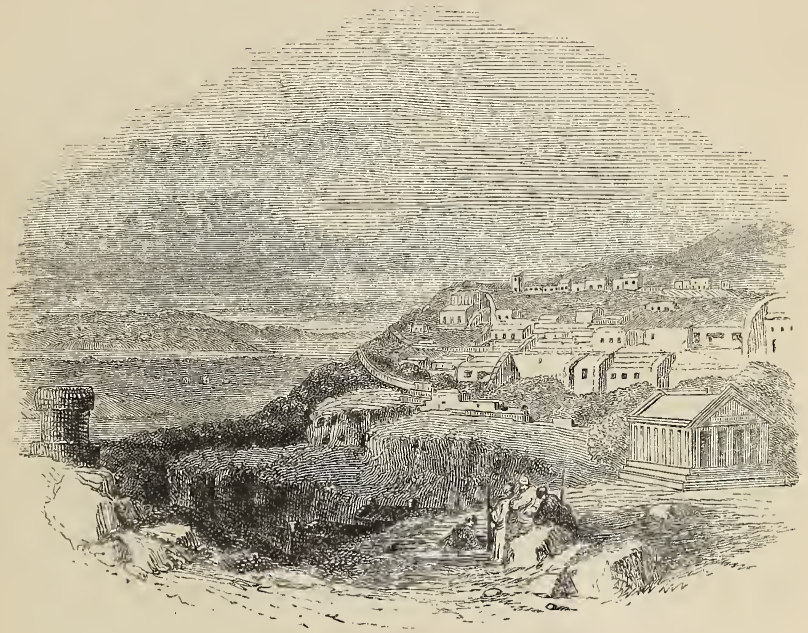

CYRENE.

incensed to madness at this retaliation; and burned to wash out the stain in the blood of their enemies. Under the command of one Andreas (who is called Luminum by Abulfaragius, and Lucuas by Eusebius), they marched hastily upon Alexandria, being joined in great numbers by the Jewish insurgents, and wasting Lower Egypt with fire and sword.

Horrible cruelties are said to have been practised by them in this insurrection, which we may be permitted to suspect, as not entirely devoid of exaggera- 
tion, since we have but the report of Dio Cassius, the Roman historian, who would probably write with somewhat of the bias of a partizan. If really enacted, the Jews might still point to the example of their enemies for similar atrocities. The historian adds a statement, however, which shows the furious and unrelenting character of the warfare. Two hundred and twenty thousand persons are said to have been slain by the insurgent Jews in Libya and Egypt. The Roman governor, destitute of troops, could do little to repel the insurrection; nor could the presence of Martius Turbo, who was sent with a large force both of infantry and cavalry to the scene of revolt, quell its power, until after many bloody battles, the result of which left Libya so depopulated that Adrian was compelled to repeople it with colonies from Europe.

While this sanguinary contest was going on in Africa, the war was raging with equal ferocity in the beautiful Isle of Cyprus. Led on by one Artemion, the Jews, who were very numerous in that island, suddenly rose and massacred two hundred and forty thousand of its inhabitants. The Jewish historians themselves state, that the slaughter was so complete that not a Greek survived in the island.* The emperor Trajan sent Adrian, the commander-in-chief of his forces, and afterwards his successor, with a

* Eusebius seems to conine the ravages of the Jewish insurgents to the city of Salamis ; but the number of the persons massacred, 240,000, added to that of their murderers, whom we must suppose equally numerous, would give a population of half a million, which would be far too great for a single Cyprian city. 
large army against the revolters, who having signally defeated them with great loss, compelled the remnant to evacuate the island. In revenge for the perfidy which marked the commencement of the insurrection, the Jews were prohibited by law from

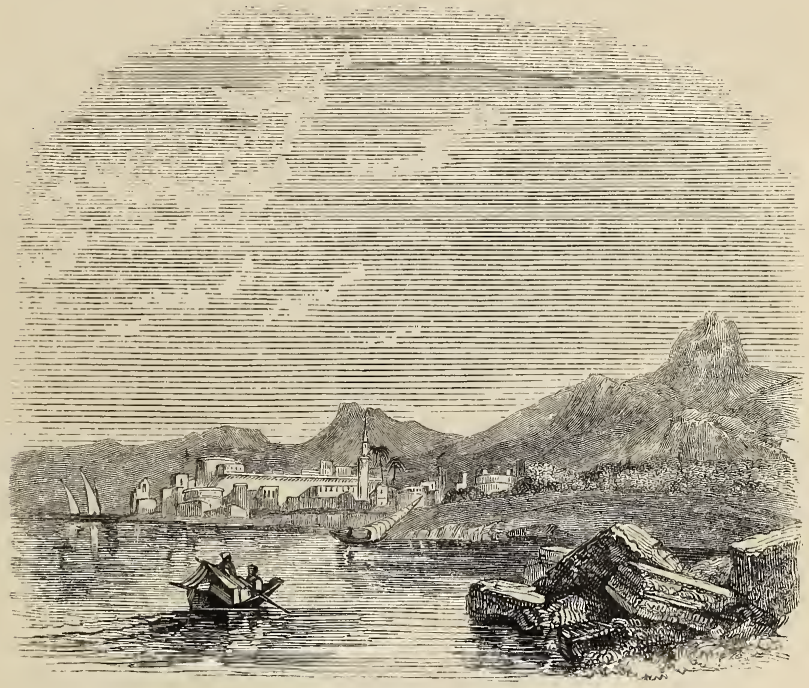

CYPRUS.

even landing there; and so rigidly was the edict enforced, that it is said, if a Hebrew were shipwrecked on the inhospitable shore, he was instantly put to death.

In the following year the insurrection broke out afresh in Mesopotamia. This province, which had belonged to Parthia, had just been transferred to Roman jurisdiction by the victorious arms of Trajan; and the Jews, who had hitherto lived in 
peace and comfort under the shadow of the Parthian kings, found themselves suddenly subjected to the hateful yoke of the Romans, with its attendant oppressions and exactions. They rose, in imitation of their brethren ir Africa and Cyprus; perhaps with the hope of creating a diversion in favour of the former, where the revolt was not yet subdued. By the efforts of Lucius Quietus, a Moor by birth, but esteemed one of the ablest of the Roman commanders, this revolt was soon suppressed; but the orders of the emperor to expel the distracted nation from the province involved a task to which all his powers were unequal; and the Jews remained in Mesopotamia. The appointment of Quietus to the government of the province not only shows the ability of the general, but also proves that the spirit of rebellion, however kept in check by his presence, was still unsubdued.

The losses of the Jews in these desperate and sanguinary conflicts are estimated by themselves at 600,000 men, - an enormous number, but nearly equalled by the aggregate of their enemies slain in Africa and Cyprus : and though we are not informed what loss befel the Roman arms in Mesopotamia, the carnage already mentioned amounts to considerably more than a million of human beings. It does not appear that any prisoners were made.

The emperor Trajan did not long survive the pacification of the East, for he died in the summer of the year 117, and his successor Adrian, who had been personally engaged in the late Jewish war, had entertained feelings of aversion towards his Hebrew 
subjects. "He had been an eye-witness of the horrible scenes which had desolated the lovely island of Cyprus; he had seen the voluptuous Idalian groves reeking with blood, or unwholesome with the recent carnage of their inhabitants, - the gay and splendid cities reduced to the silence of desolation."* It is not wonderful, therefore, that he should look upon them as a race unworthy of respect or confidence, and to be kept in order only by being crushed under the heel of a vigorous and severe despotism.

The provinces conquered by Trajan were indeed relinquished by his successor; and thus the Mesopotamian Jews were restored to the mild and equitable yoke of Parthia. But throughout the Roman world, the broken and scattered children of Israel, already smarting under their sore disappointments, were destined to groan under the galling tyranny of Adrian. Others had made their yoke heavy, but he added to their yoke; others had chastised them with whips, but he chastised them with scorpions. $\downarrow$

Adrian laboured to effect by enactments what he had been unable to accomplish by arms, - the utter extinction of the Jewish race as a distinct people. He forbade the observance of the Sabbath, which formed so broad a distinction between the worshippers of Jehovah and the Pagans; he prohibited the reading of the Law, by which alone the people could be instructed in those divine ordinances which had drawn a broad line of separation between Jew and Gentile; above all, he interdicted the rite of circumcision, the solemn seal of that covenant which 
had been made by GoD with the great progenitor of the Hebrew nation, on the non-performance of which every national blessing, and even nationality itself, would be forfeited; so peremptory was the Divine command.

And God said unto Abraham, Thou shalt keep my covenant therefore, thou, and thy seed after thee in their generations. This is my covenant, which ye shall keep, between me and you and thy seed after thee; Every man-child among you shall be circumcised. And ye shall circumcise the flesh of your foreskin; and it shall be a token of the covenant betwixt me and you. And he that is eight days old shall be circumcised among you, every man-child in your generations, he that is born in the house, or bought with money of any stranger, which is not of thy seed. He that is born in thy house, and he that is bought with thy money, must needs be circumcised: and my covenant shall be in your flesh for an everlasting covenant. And the uncircumcised man-child whose flesh of his foreskin is not circumcised, that soul shall be cut off from his people; he hath broken my covenant. Gen. xvii. 9-14.

A law was made, and rigidly enforced, that any one throughout the Roman dominions who either circumcised his children, or submitted himself to that rite, should be banished; the physician who performed the operation was to be put to death; while the same punishments were enforced on those Jews who proselyted the Pagans, or circumcised Pagan children. But Judaism, though sorely visited, was not to be rooted out by any effort of the heathen; He who had so severely smitten His ancient people had not forgotten His ancient covenant; He had cast them, as of old, into the iron furnace, but $\mathrm{He}$ had decreed their preservation there: like the wondrous bush seen by their great lawgiver at Mount Horeb, they were indeed to be "burned with fire, but not consumed." 
Behold, the eyes of the Lord Gov are upon the sinful kingdom, and I will destroy it from off the face of the earth ; saving that I will not utterly destroy the house of Jacob, saith the LoRD. For, lo, I will command, and I will sift the house of Israel among all nations, like as corn is sifted in a sieve, yet shall not the least grain fall upon the earth. Amos ix. 8, 9 .

At the same time, to cut off from the Jews all hope of ever regaining possession of their desolate, but still beloved City, and of re-establishing the Temple of Jehovah, Adrian determined to occupy Jerusalem with a Roman colony, which involved the alienation of the soil, and the bestowment of it in perpetuity upon strangers.* Accordingly he began to rebuild the city, to which from his own name, Ælius Adrianus, he gave the name of Elia, instead of its ancient appellation. To crown all, he decreed the erection of a Pagan temple on the mountain where the Holy House of Jehovah had stood, and its dedication to Jupiter Capitolinus. How far these designs were put into execution before the Jews burst forth into new revolt, is not quite certain, as the testimony of historians is conflicting. Eusebius places the transmission of the colony to Judea after the storming of Bither, and the suppression of the sanguinary rebellion which we shall

* The difference between a Colonia and a Municipium lay in this: that, in the latter, the inhabitants of a conquered town were left in undisturbed possession of their property in the land, the exercise of their political rights, and the administration of their local laws, while they obtained some of the privileges of Roman citizens. In a Colony, a body of persons were sent from the mother country to occupy the conquered town, receiving its lands as their own property, governing themselves according to Roman laws, and enforcing the Roman authority over the subject province. The former was a foreign limb engrafted on the Roman stock; the latter was a shoot of the Roman tree transplanted into a foreign soil. 
presently narrate; but Dio Cassius, the Roman historian, asserts positively that the colony was the occasion of the war; and that the Jews, being infuriated by the presence in their sacred city of those who worshipped strange gods, took up arms to expel them. It is probable that the decree of Adrian, and the commencement of its execution, might have produced the ferment, and deferred the completion of the imperial purpose until after the subjugation of the province.

The Jews themselves, in their traditions, attribute the actual outbreak of hostilities to an incident sufficiently trivial; but their testimony in this instance will not be rejected as improbable, when we reflect how often, in the most important revolutions, an event the most minute and unexpected has proved the match by which the whole train has been set in a blaze. "It was customary in Judea for each family to plant a cedar before the house at the birth of a son, and a pine at the birth of a daughter. These trees were deemed sacred, and were not cut down till they were needed to form their marriagebed. The daughter of Adrian was travelling in Judea, when her chariot was injured, and her attendants proceeded, in an overbearing manner, to cut down one of the sacred trees, to be used in repairing it. The inhabitants of the place rose and massacred the train of the princess, who was so enraged that she forced her father to make war against the Jews to humble their pride."

At this moment, when the whole nation was kindling into a flame, the general enthusiasm was raised to the highest pitch by the startling an- 
nouncement that the Messiah had appeared. An adventurer named Simeon, whose early history is unrecorded, suddenly gave out that he was the longannounced and long-expected Christ; and, in allusion to the renowned prophecy of Balaam, took the appellation of Bar-Cocheba, or the Son of a Star. His cause was espoused with ardour by Akiba, the most illustrious of the Rabbis.

Akiba, or Aquiba-ben-Joseph, is said to have been descended from Sisera, the general of Jabin, who fell by the hammer and nail of Jael. $\mathrm{He}$ began life as a shepherd, keeping the flocks of a rich citizen of Jerusalem. Falling in love with his master's daughter, but rejected on account of his low condition, he applied himself to study, and returned at the end of twelve years to claim his wife, with twelve thousand disciples at his feet. Her father disinherited her on learning her union with Akiba, and the latter returned to his college, whence, after twelve years more, he again visited his father-in-law, with twenty-four thousand disciples. His transcendent reputation overcame the obstinate resentment of the wealthy sire, who, rescinding his angry vow, bestowed his favour and his wealth on the happy pair.

The Talmud abounds with details of the sayings and doings of this marvellous Rabbi, as extravagant as they are minute. The divine revelations made to him are declared to have been greater than those made to Moses. A thousand maxims, reputed to contain the most profound wisdom, were delivered by him, and the whole of the Mishna is by some ascribed 
to him. An entire volume might be filled with passages from his memoirs. One hundred and twenty years are assigned to his life, in rivalry of his predecessor Moses.

Such are a few of the fables with which Jewish tradition has adorned the attendant of the selfstyled "Star." Patriotism, or ambition, at once determined the Rabbi to cast the whole weight of his immense influence into the scale of the bold adventurer. "Behold!" cried he, in a conclave of the people, "this is the Star out of Jacob! The redemption of Israel is come!" And he immediately announced himself as his precursor and standardbearer. The new leader seems to have been a man of great abilities, fitted by his address and intrepidity for the command of men. He is said to have awed the most sceptical into an acknowledgment of his lofty claims, by the exhibition of miraculous powers; among the chief of which is recorded that of sending forth a stream of fire from his mouth, a feat equalled by many a conjuror at modern country fairs, but then supposed to indicate the flaming vengeance with which he would burn up his enemies before his face.

The meek and holy Jesus, the true Christ of God, had long ago declared, "I am come in my Father's name, and ye receive me not; if another shall come in his own name, him ye will receive." * The fame of the pretender spread like lightning; and two hundred thousand men in arms are said to have flocked from all parts of the world to 
the standard again uplifted on the mountains of Judea. The Christians alone refused to acknowledge his assumptions, and were persecuted by him with great barbarity. Having overpowered the feeble garrison of Jerusalem, Bar-Cocheba made himself master of the Holy City, assumed the title of King, and issued coins, inscribed on the one side with his own name, and on the other with the words "Freedom of Jerusalem." One of these is in the British Museum: one side represents a portion of four columns, in the midst of which is a lyre; a serpentine stroke below is said to represent the brook Kidron, and a star alludes to his name and pretensions. On the reverse is a pot of manna and a leaf. The inscriptions read "Simeon," and "Freedom of Jerusalem." It is proper to add, however, that this coin is, by some numismatologists, assigned to a higher antiquity, and ascribed to Simon Maccabæus.

The Roman lieutenant in Judea at this time was T. Annius (or Tinnius) Rufus, called by the Jews Turnus Rufus, and perpetually confounded by them with Terentius Rufus, the stern desolator of Jerusalem after the conquest by Titus. The force which this commander was able to bring against BarCocheba was wholly unable to quell the insurrection. He exercised, indeed, the most unrelenting severities on the prisoners who fell into his hands, slaying many thousands of men, women, and children; but these barbarities could not retard the steady progress of the Jewish leader, who gradually got into his possession many places of strength. He chose as his 
metropolis, not Jerusalem, which, although partially, perhaps, rebuilt, was still unwalled, but Bither, a city in the neighbourhood of it, a stronghold on the summit of a craggy mountain. Here he was crowned as King Messiah, and here he issued his coin.

The emergency was so great that the emperor at length recalled from Britain the most renowned of his commanders, Julius Severus. On his arrival in Judea, he found a victorious enemy, with fifty fortresses in his possession, and nine hundred and eightyfive villages. This able general soon turned the tide of success, and sustained his military reputation. Avoiding a decisive engagement with so powerful an adversary, he harassed his forces in detail, straitened his quarters, captured his convoys, stormed his fortresses, and at length laid siege to Bither.

The insurgent king made a desperate resistance, and the strength of his citadel for a time defied the Roman besiegers. How long it held out is not known, but it was at length stormed, and a general massacre ensued. Bar-Cocheba himself was slain, and his head was brought to Adrian. The day on which this calamity took place was once more the memorable 9 th of $\mathrm{Ab}$, the day on which the Temple had been destroyed, first by Nebuchadnezzar, and afterwards by Titus. The Jewish writers relate that the slaughter was dreadful. A greater number are said to have perished than those who came out of Egypt under Moses. The students of the numerous colleges were burned to death with their books tied to them. The skulls of three hundred infants were found on a single rock: the horses 
waded up to their bits in human blood, which flowed so copiously that great stones weighing four pounds each were carried by the force of the current to the sea. The corpses covered the ground for eighteen square miles; and so saturated was the soil with gore, that the cultivators had no need to manure it for seven years. The Roman historian, Dio, affirms that during this war the number of those who fell by the sword amounted to 580,000, besides those who perished by famine, disease, and fire. Judea was turned into a desert once more; wolves and hyenas howled in the streets of the desolate cities. The Romans also, according to the same authority, suffered severely in this sanguinary war; they were often defeated, and lost the flower of their armies. It was indeed a war of horrors.

The aged Rabbi who had contributed so much to the delusion of the miserable populace was consigned to a terrible and barbarous fate. The traditions of the Talmud have recorded the singular constancy of this man. Being arraigned before T. Rufus, in the midst of his examination he recollected that it was the hour of prayer. Indifferent to the presence of his cruel judge and the heathen spectators, he instantly fell on his knees, and calmly, as though he were in his closet, performed his devotions. In prison he preferred to use his scanty pittance of water in the performance of the ordained ablutions to quenching the burning thirst with which his throat was parched. Adrian ordered him to be flayed alive, by means of iron combs; a horrible and diabolical act of vengeance. 
As on the former reduction of the rebellious province, so on this occasion, the common people were consigned by thousands to slavery. In the south of Judea stood a venerable terebinth-tree of gigantic size, whose existence tradition carried up to an antiquity so remote, that Abraham was believed to have pitched his tent beneath its spreading shelter, and to have there entertained the three angels who were sent against Sodom. An annual fair of merchandize from time immemorial had been held under its boughs; and here the miserable Jews were brought by droves, and sold like cattle. Those who remained unpurchased here were afterwards driven to another mart at Gaza.

Some writers have supposed that T. Annius $\mathrm{Ru}-$ fus at this time ploughed up the very surface of Jerusalem; but this seems to have arisen from the Jewish habit of confounding him with Terentius Rufus. It is more consonant with historic testimony, as well as with probability, to believe that Adrian pursued his original design of rebuilding the city by the name of Elia Capitolina, though in so doing he would doubtless have to dig up many of the foundations of the ruined buildings. The circuit of the new walls embraced a wider area than that of the old; but the stones of the dismantled fortifications were largely used in constructing them. The massive hewn stones, that had excited the wonder of beholders in the construction of the magnificent Temple, were now employed to build a theatre. These desecrations would be sufficiently galling to the minds of the Jews; but the vindictive 
emperor still further insulted their religious feelings by placing the statues of idols on the site of the Sanctuary, and by placing over the gate that led towards Bethlehem the figure of a swine, of all animals the most abhorrent to a Jew. He enacted a law, prohibiting, under pain of death, any Jew from entering the city, or even from gazing on it from the neighbouring hills; but the Roman soldiery made a gain of this edict, by selling at a large price the painful privilege, not the less prized because dearly bought, of weeping over the venerable ruins, and scattering perfumes over the stones of the Temple.

Adrian celebrated the subjugation of Judea by the issue of medals, one of which bears the figure of a woman sacrificing, and holding two naked children by the hand. It has been ingeniously conjectured that the woman is intended to represent Judea, who consents, by the sacrifice, to receive the pagan religion, and that the naked children imply the renunciation of circumcision. There is another medal of this reign, representing Judea as a woman on her knees, stretching out her hand in supplication towards the emperor; three children are with her, one of whom is naked, who appear to join in their mother's entreaties.

The actual site of Bither, where the tragic scenes were enacted, which a second time extinguished the hopes of the broken children of Israel, has until lately eluded the research of modern topography. Some have supposed it to be the same as Bethhoron, others Bethel. But it seems to have been recently identified in a satisfactory manner by the 
Rev. G. Williams, whose interesting words we here subjoin. "It is a great satisfaction to have it in my power to determine beyond all doubt the site of this important position, which has so long and so strangely baffled the search of the curious. I say strangely, because its situation in the neighbourhood of Jerusalem, where Eusebius has taught us to look for it, the fact of its retaining its ancient name entirely unaltered-which has even found its way into the later maps, and lastly, the local traditions existing among the native Mahometans-certainly not taught, because not known, by monks and travellers-contribute to form a chain of evidence for its identity stronger far than any I met with in Palestine, excepting such as I was prepared to expect. The importance of the subject will, I trust, excuse the digression and minute detail.

"Having heard of the existence of a village in the vicinity of Jerusalem, whose name appeared of sufficient interest to justify a visit, I took with me a Mahometan guide, a peasant of Ain Karim, and on Friday the 28th of April, 1843, went in quest of Beiter. Leaving the Convent of the Cross, and Ain Malakh, on the right, and Beit Safâfa and Es-Sherafât on the left, I followed the deep Wady Hannieh, until, after passing the fountains of Yalo and Wellager, I found a valley running into it from the left, which comes down from the neighbourhood of Beit Jala. This last Wady derives its name from the village of which I was in quest, standing at the point of juncture of the two valleys. The first feature that attracted my attention, as 
I approached the spot, was a lofty hill, projecting into the valley, which surrounds it on three sides, attached to the modern village by a rocky isthmus. On this hill my guide pointed out Khirbet el Yehûd (the 'Ruins of the Jews'), of which he had volunteered mention on the road. Following a track down which a copious stream of water was flowing, I came to a fountain which rises above the village, having a passage cut through the solid rock to the source. In this passage I found the Sheikh of the village, and immediately engaged his services. On inquiring if there were ruins in the neighbourhood, the Sheikh and several villagers who had congregated, with one voice repeated the welcome words ' Khirbet el Yehûd,' pointing to the hill over against us. Under the guidance of the Sheikh I ascended to it, passing on the way some large caverns in its rocky sides, in some of which he said there was architecture; but they were blocked up, and I could not explore them. On reaching the summit of the hill, my guide conducted me, without the slightest hesitation, to the ruins of ' a tower' on the north, near which he pointed out the remains of an 'old wall,' which he told me had surrounded the hill. There was also a 'second tower' on the south side, the ruins of which are very distinct, though the masonry is not striking but solid; and beneath this he directed my attention to 'a fosse,' which had been contrived by art for the fortification of this remarkable position. Surrounded by the almost precipitous valley on three sides, the hill was by nature impregnable, 
except on the south, where, as was said, it was attached to the modern village and the mountain region above it by a rocky isthmus. This isthmus had been cut through, and a deep trench formed to guard the approaches in that quarter; and a stronger position for ancient warfare can scarcely be imagined. Having explored the spot for some time, and made my notes, I was well satisfied with the result of my visit, and was about to commence the descent, when the Sheikh pointed to the hills behind the modern village, rising to about the same height as that on which we stood, and remarked, 'They shot at them from that hill.' 'Who shot at whom ?' I inquired. 'Oh! I don't know,' he replied ; 'it was a long while ago. How should I know ?'

"Strange that the tradition of the siege by the Romans should have been handed down to this day, in this vague form, among the infidels! for there are none but Mahometans in the village; and the Greek monks at Jerusalem, to whom I afterwards mentioned the facts, knew scarcely of the existence of the village, much less of its traditions! The site is more circumscribed than I had expected to find it; the wall which surrounded the hill could scarcely have exceeded a mile in circuit; but this difficulty may be solved by the supposition of the town having covered the hill on whose side the modern village now stands, and to which the isolated hill would form the acropolis. The traditions of the rabbies respecting the extent of Bether are no doubt absurdly exaggerated; but it is incredible that its whole population should have been so long 
cooped up within such narrow limits as those above described. Whatever solution may be offered to this difficulty, I do not apprehend that any objections can avail to set aside the evidence which has now been adduced for the identity of this site with the Bether of Jewish history; and I have as little doubt that the high region to the south of this, which I afterwards traversed on the way to El Khûdr, is described by Solomon in the Canticles as the 'Mountains of Bether,' as the valley which bounds it on the east is still called by that name." *

We may learn from the intensity of the chastisement which has fallen upon the people of Israel, God's estimate of their transcendent crime. Seventy years' captivity was the punishment of national apostacy from the worship of Jehovah; but the rejection of the mission of God the Son, and the mission of God the Holy Ghost, has been visited with a far heavier vengeance. Eighteen centuries of desolation, oppression, and contempt, have not expiated their awful sin; robbed and spoiled, hunted like wild beasts into snares, thrown into dungeons, the victims and the prey of every oppressor, with no deliverer, pitier, or avenger, they remain a monument of God's righteous ire against sin, and of the truth of His Holy Word.

But this is a people robbed and spoiled; they are all of them snared in holes, and they are hid in prison-houses: they are for a prey, and none delivereth; for a spoil, and none saith, Restore.

Who among you will give ear to this? who will hearken, and hear for the time to come?

* The Holy City, p. 135. 
Who gave Jacob for a spoil, and Israel to the robbers? did not the LORD, he against whom we have sinned? for they would not walk in his ways, neither were they obedient unto his law.

Therefore he hath poured upon him the fury of his anger, and the strength of battle: and it hath set him on fire round about, yet he knew not ; and it burned him, yet he laid it not to heart. Isa. xlii. 22-25.

"As the Jews, from age to age," observes a commentator, "read this chapter, the Lord calls upon them to reflect on their condition, and the cause, and author of it, and inquires, Who amongst them will hearken for the time to come? Nor can they assign any other reason for their longcontinued miseries, except the hot displeasure of Jehovah; nor any so evident cause of that hot displeasure as their obstinate rejection of their promised Messiah. But though he hath thus poured out upon them his indignation, and is become their tremendous enemy, and consumes them with his fiery indignation, yet they know not, and lay it not to heart; and their insensibility forms as striking a demonstration of the truth of the Scripture, as their desolate and unprecedented situation." *

* Scott, in loc. cit.
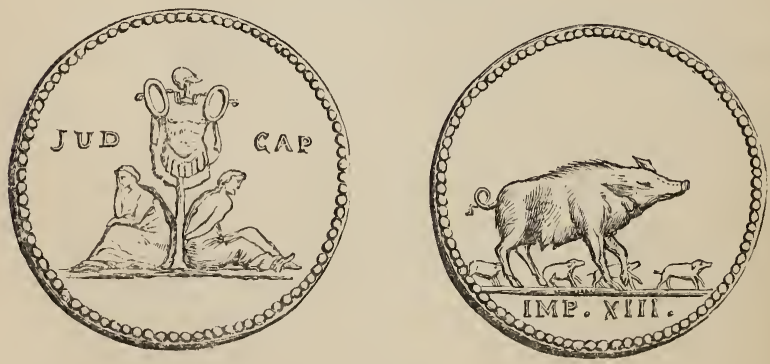


\section{CHAPTER XI.}

THE TALMUD.

A.D. $138-337$.

The fall of Bither gave a death-blow to the efforts of the Jews to regain by force of arms their place among the nations of the earth. Henceforward we find them bowing to their lot as the irresistible decree of God, and in some measure, by acknowledging its justice, "accepting the punishment of their iniquity." Dispersed among all nations; scattered into the most remote parts of the earth; found alike in the great and populous cities of the world, and in the inhospitable districts of the frozen north, and the burning south; with every probability of alienation from each other, and with every apparent motive for amalgamating with the various Gentiles among whom they might be cast; they present to us the astonishing spectacle of a people as isolated from all others as when comprised within the narrow precincts of Judea, bound together by an unseen principle of unity, and a band which no human power can avail to sever.

From the accession of Antoninus Pius in A. D. 138 , to that of Constantius in $33 \%$, the Jews make 
little figure in history, and appear to have reposed in quietude and comparative prosperity. The former emperor, indeed, is claimed by Rabbinical tradition as a Jewish proselyte, ardently attached to the Hebrew faith, and as a participator with Rabbi Judah the holy (of whom we shall presently speak) in the compilation of the Mishna. Such stories, we need scarcely say, are as apocryphal as most of the history handed down through the same channel. The more rigid of the enactments of Adrian were, indeed, repealed by Antoninus; but they were again enforced by Marcus Aurelius, in revenge, because the Jews had aided his enemies in a new Parthian war. But this severity seems to have been of short duration, and on the return of Severus from his Parthian campaign (A. D. 198), several edicts favourable to his Jewish subjects were issued by the victorious emperor; so that they applied to this relief the words of the Prophet Daniel,* "Now when they shall fall, they shall be holpen with a little help." Caracalla and Heliogabalus seem both to have looked on the dispersed people of Israel with indulgence, notwithstanding that the tyranny of the one, and the effeminate vice of the other, render their names in other respects sufficiently hateful. And the wise and amiable Alexander Severus, whose reign has been designated "a beautiful oasis in the desert of this period of the imperial history," was imbued with so deep a reverence for the Jewish religion, that the wits of the day lampooned him under the title

$$
\text { * Dan. xi. } 34 \text {. }
$$


of Chief of the Synagogue. By a well-meant though ignorant homage, this virtuous prince placed a statue of Abraham in his private chapel, among the men whom he considered worthy of divine honours.

It might have been expected that a people who had so acutely felt the bitterness of persecution themselves, would have learned to look with leniency, if not with respect, upon their fellow men whose only offence was difference in matters of faith. But, on the contrary, their rage against the Christians seems to have been even more rancorous than against the heathens themselves; and they seem to have been ever ready with cruel joy to promote and to aid any persecution of the disciples of Jesus. The martyrdom of the holy Polycarp (A. D. 167) at Smyrna exhibited a painful example of this bitter spirit; for they not only filled the theatre with furious cries and imprecations upon him as an atheist during his trial, but howled with savage triumph around the stake while the flame was devouring his body; and, as if death itself could not satiate their implacable rage, they solicited the judge that the friends of the martyr might not be allowed the consolation of possessing his honoured ashes.

When they had not the power of inflicting any positive injuries on their Christian brethren, they never failed to invoke the most direful curses on them and their faith; sending forth messengers throughout the world (if the testimony of the Fathers may be received), for the purpose of blaspheming the sacred name of Jesus in every syna- 
gogue, and of uttering a solemn anathema upon His disciples as impious atheists.*

As the sin of the Jewish people had been for ages growing more ripe for judgment, so their dispersion among the nations, which had been the subject of prophecy, had commenced centuries before the uprooting of their national polity. We not only find in the Acts of the Apostles, "Jews, devout men, out of every nation under heaven," assembled at Jerusalem at the Feast of Pentecost, but also Jewish synagogues established in most of the cities of Asia Minor, Greece, and Rome. In the great and populous cities of Antioch in Syria, and Alexandria in Egypt, the numbers of Jews and of Greeks seem to have been nearly evenly balanced in Josephus' time ; and Strabo, still earlier, bears testimony to their ubiquity. His words are, "Now these Jews are already gotten into all cities; and it is hard to find a place in the habitable earth, that hath not admitted this tribe of men, and is not possessed by them. And it hath come to pass that Egypt and Cyrene, ... a and a great many other nations, imitate their way of living, and maintain great bodies of these Jews. . . . Accordingly, the Jews have places assigned them in Egypt, wherein they dwell, besides the portion exclusively allotted to this nation in Alexandria, which is a great part of the city. They have also an ethnarch allowed them, who governs them and administers their laws, as if he were the ruler of an independent republic." If Jewish tradition were worthy of credit, we might

* Justin; Dial. with Trypho. 
indeed assign the settlement of Hebrew colonies in western Europe to a high antiquity, for the Rabbinical writers claim a descent for the Spanish Jews from maritime adventurers in the days of Solomon. And if we look to Asia, we have better authority for knowing that the countries successively subject to the sway of Assyria, Babylon, and Persia, extending "from India to Ethiopia," were inhabited by this " peculiar people ;" for of the ten tribes carried away into Assyria, nearly the whole, and of the two tribes taken to Babylon, probably the majority, remained in permanent exile.

After the fall of Jerusalem a prodigious number of unhappy captives were scattered over the Roman empire; while we may reasonably suppose that as many as had the power, would prefer to seek a refuge with their Oriental brethren, who were enjoying peace and prosperity under the mild rule of Parthia. Thus was the dispersed nation divided into two parties, acknowledging, indeed, the common brotherhood, but insensibly becoming more and more distinct in their government, customs, and literature. The Eastern Jews were principally settled, as we have observed, in the provinces which had constituted the Babylonian kingdom; and the city of Babylon was, if the expression may be allowed, their metropolis. The Western Jews were much more scattered: Egypt and Cyrene at first received an immense number, but the revolts under Trajan and Adrian nearly extirpated these; Spain seems to have possessed the most considerable families, who were accustomed to look down with pride on 
their poorer brethren, asserting that they alone had preserved their genealogical distinctions, and that the blood of the Royal house of David flowed in their veins. But a superior claim to distinction was maintained by those few but learned men who constituted the Rabbinical schools, and who still lingered in their native land. The Jews maintain that the Sanhedrim, or great judicial council of the nation, composed of seventy-two elders, never died out, nor ever quitted the land of Israel, through all the troubles of the national desolation. They describe it, as abandoning first the Sacred Courts of the Temple, and then Jerusalem, and fleeing from city to city, as the storm threatened its existence, until at length, by the indulgence or the contempt of the heathen conquerors, it found a home and a refuge on the now peaceful shores of the Sea of Galilee.

The city of Tiberias had escaped the avenging sword of Rome, when it fell so keenly on the neighbour cities; and here the acknowledged President of the Council, Simon, the son of Gamaliel (the only student who survived the destruction of Bither) gathered around him the remnant of Rabbins that constituted this high court of judicature. The President took the title of Rosh Abboth, or Chief of the Fathers, an appellation which the Greeks literally render by the term Patriarch. Without any power to enforce his decrees, it is matter of astonishment how so shadowy a legislator could obtain a recognition of his authority not only over the whole of the Western Jews, but even over the broken remnant 
that remained about his place of residence. Yet his authority did increase, and extend; and that so rapidly, that in less than a century after the second desolation by Adrian we find the Patriarch of Tiberias universally acknowledged by the Jews throughout the Roman world as the great spiritual Head of their nation; "his mandates obeyed, his legates

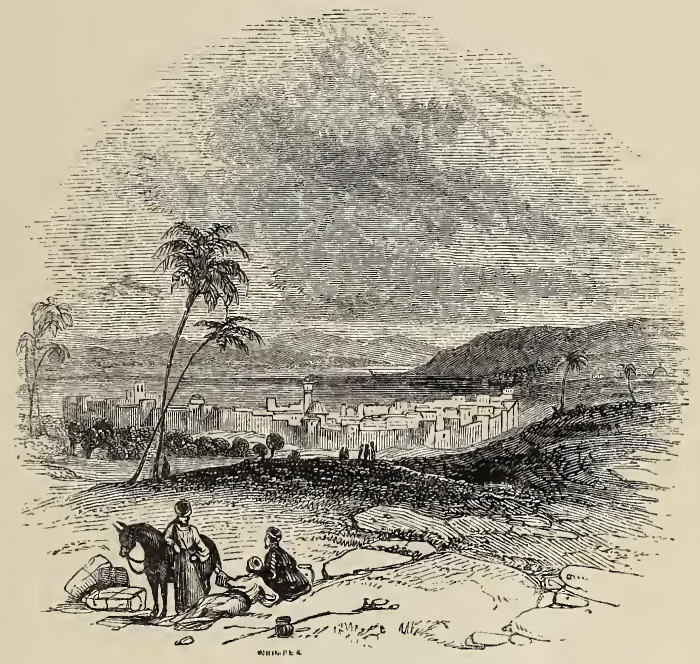

TIBERIAS.

received with honour, his supplies levied without difficulty, in Rome, in Spain, in Africa." Origen bears witness, from personal knowledge, that the power and state of the Patriarch of the West were little less than those of a monarch, extending even to the execution of capital punishment for crimes against the Mosaic Law. 
'The successor of Simon was Judah, commonly called Hakkodosh, or "the Holy;" a man who exercised a momentous influence on the dispersed nation, an influence extending with almost undiminished power even to the present time. For to him is Judaism indebted for the Mishna.

The Law of God, as originally given to Moses, had been gradually obscured, and made of none effect, by a constantly increasing heap of traditionary observances, often absurd, generally puerile, and not infrequently contradictory to the Law which they professed to explain, yet enforced as of equal if not superior authority. It was pretended, that, besides the precepts contained in the written Word, there had been a number of commands given by God to Moses, equally binding on the conscience, which had never been committed to writing, but had been handed down by uninterrupted tradition, through the Elders; and this was called the Oral Law. The prurient ingenuity of the human mind had exercised itself for ages in inventing silly conceits and childish fables, as the sanctions of a ceaseless round of meaningless observances, the attention to which had become a "heavy burden, and grievous to be borne." These had already in our Blessed LorD's day so overlaid and hidden the commandments of God, as to reduce them to a nullity; and in the following and other passages we have His severe but righteous judgment on their traditionary system :

Then came to Jesus scribes and Pharisees, which were of Jerusalem, saying, Why do thy disciples transgress the tradition of the elders? for they wash not their hands when they eat bread. But he answered and 
said unto them, Why do ye also transgress the commandment of God by your tradition? For God commanded, saying, Honour thy father and mother: and, $\mathrm{He}$ that curseth father or mother, let him die the death. But ye say, Whosoever shall say to his father or his mother, It is a gift, by whatsoever thou mightest be profited by me; and honour not his father or his mother, he shall be free. Thus have ye made the commandment of God of none effect by your tradition. Ye hypocrites, well did Esaias prophesy of you, saying, This people draweth nigh unto me with their mouth, and honoureth me with their lips; but their heart is far from me. But in vain they do worship me, teaching for doctrines the commandments of men. Matt. xv, 1-9.

But the evil had still gone on, and increased: for besides the Written and the Oral Law, which may be considered as the foundation of the vast structure, there had been constantly accumulating comments on their various precepts, made by learned men, whose diverse and often contradictory opinions had led to discussions, citations of precedents, summings-up, and balancings of authority, without number or measure. And in proportion as true religion and real respect for the Word of God declined, superstition and zeal for frivolous punctilios increased; the demand produced the supply, and at length all wisdom and learning in the nation were concentrated in the study, in the repetition, and in the creation, of these unwieldy traditions. "A race of dreaming schoolmen contrived to place an avowed collection of mere human decisions among the hallowed verities and the duties of devotion: to graft opinions of men on the scion of divineinstitution; nay, even to prefer the gloss in direct opposition to the divine precept, whenever, as they express it, 'the tradition is not favoured,' that is, when the oral tradition absolutely contradicts the written law." 
"The imposture of the Divine origin of their traditions found such favour in the eyes of the Hebrews, that, to confirm the faith of the sceptic, it was carried on with renovated vigour. They have deduced by names a series of 'the receivers of the traditions,' in chronological order. Their oral law was perpetuated by Joshua, the judges, the prophets, and descended to the chiefs of the great synagogue, Ezra, Nehemiah, and others. A new dynasty of the ' receivers of the traditions,' for with oriental luxuriance they title their later Rabbins ' the Princes of the Captivity,' have their names and reigns recorded in the Jewish annals of their divinity schools. . . .

"The truth is, that Judaism had found its last asylum in its numerous academies or colleges, which boasted of a race of Mishnaical doctors, residing at different places. A strange and wondrous spectacle was now exhibited to the universe. A conquered nation had changed their military leaders into Rabbins, and their hosts into armies of students. We have accounts of these pale-cheeked squadrons, covered only with the dust of the schools; but where ten and twenty thousand disciples were practising their tactics under some able chieftain of the traditions." *

It is probable that these cumulative precepts were not exclusively oral. "Collections," observes Dr. M'Caul, "greater or smaller for private use, must have been made from the earliest times, as it seems scarcely possible to imagine that men should * D'Israeli; The Genius of Judaism, pp. 78, 83, 85 . 
be acquainted with writing, and yet not write that which was of every day concernment. The oldest collection known appears to be that of the school of Hillel [about the beginning of the Christian era]. To Rabbi Akibah is ascribed the first distribution into orders. The school of Simon the son of Gamaliel, about the year 166, made further collections." *

But it was reserved for the genius, the diligence, and the zeal of Rabbi Judah to collect and digest into a written code the fleeting decisions of his ancestors, and thus to give precision and stability to their authority. This voluminous digest was called Mishna, or Repetition. It treats of the most heterogeneous things; as the following list of its chapters will show; for Rabbinic authority intermeddled with every transaction of life, from the solemnities of the Great Day of Atonement, down to the manner in which a man must wash his hands. The Mishna is arranged under six Orders.

\section{ORDER I.}

LAWS CONCERNING SEEDS AND FRUITS.

Book 1. Thankgivings and blessings.

"2. On leaving corners in the field unreaped.

"3. On doubts whether tithes have been paid.

"4. Oblations.

" 5. The Sabbatic year.

"6. Unlawful mingling of diverse things.

"7. Tithes given to the Levites.

" 8. Second tithes; to be eaten at Jerusalem.

,9. Of the priest's cake.

$" 10$. Of not eating of fruit, till the tree is five years old.

,11. The first-fruits.

* Dissertation on the Rabbinic Authorities ; London, 1845. 


\section{ORDER II.}

OF THE SEASONS AND FESTIVALS.

Book 1. The Sabbath.

"2. Mixtures or associations for courts and entries, the inhabitants of which are allowed to carry food from one house to another [on the Sabbath?].

"3. The Passover.

" 4. The yearly half-shekel.

" 5. The Day of Atonement.

"6. The Feast of Tabernacles.

"7. Days of Holy Convocation.

" 8. The new year, and new moon.

9. Fasts.

"10. Feast of Purim.

"11. Lesser festivals, or days intervening between the first and seventh days of convocation.

"12. The appearance of the males at the three great yearly Feasts.

\section{ORDER III.}

\section{LAWS PERTAINING TO WOMEN.}

Book 1. Marriage with a deceased brother's wife.

"2. Dowries, settlements, and women's estates.

"3. The vows of married women.

"4. Concerning different sorts of Nazarites.

"5. Trial of jealousy, adultery, \&c.

"6. Divorces.

"7. Espousals, and ceremonies previous to marriage.

\section{ORDER IV.}

INJURIES, PUNISHMENTS, AND REPARATIONS.

Book 1. Damages received from man, or beast.

"2. Usury, and letting out to hire.

"3. Laws of partnership, of buying and selling, and of inheritance.

"4. The Sanhedrim, and inferior courts of justice; crimes punished by them; evidence. 
Book 5. False witness; city of refuge; forty stripes, and why one was subtracted.

"6. Administration of oaths.

"7. Legal decisions of the rabbis.

"8. Idolatry of various kinds.

"9. The fathers; history of traditionary lore.

"10. Punishment of those who broke the decrees of the Sanhedrim.

\section{ORDER V. \\ HOLY THINGS.}

Book 1. Sacrifices; their nature, by whom, when, and how to be offered.

„2. Clean and unclean animals.

"3. Oblations of flour, wine, and oil, in sacrifices; the two waveloaves.

4. Laws of the first-born, their redemption or sacrifice: tithes of cattle.

5. Valuation of devoted things.

"6. Exchange of sacred things.

\% 7. Sacrilege ; transgression in sacrifice.

" 8. Excision, or excommunication from Israel.

"9. The daily sacrifice, how and when to be offered.

"10. The dimensions and proportions of the temple, of the outer court and sacred mount.

"11. Pigeons, or turtle-doves, offered by the poor.

\section{ORDER VI.}

\section{POLLUTIONS AND PURIFICATIONS.}

Book 1. Pollutions of vessels, and garments.

"2. Pollutions of tents and houses, and of those who enter them.

"3. Plagues; leprosy, and its cleansing.

"4. The red heifer, water of separation, \&c.

,5. Purification from sundry pollutions.

"6. Baths for purification.

"7. Pollutions and purifications of women.

8. Pollution of seed, or fruits.

,9. Uncleanness of issues.

"10. Pollutions not removed till sunset.

"11. The washing of hands.

„12. Pollution of fruits by touching the stalk. 
The publication of this voluminous collection of laws hitherto unwritten, though received at first with hesitation by the more cautious Rabbins, was quickly hailed with enthusiasm; and the code acquired all the authority which its compiler could desire, superseding the Law of Moses, which it professed to explain. But if the zealous Judah hoped to settle by this laborious work the letter of the law, and to give fixity and certainty to that which had hitherto been fleeting and uncertain, he was greatly mistaken. The process of debate and comment went on with unabated vigour: perhaps with the more zest because of the new and wide field thus opened to its exercise. "The Mishna," says the acute, but sarcastic, D'Israeli, "at first considered as the perfection of human skill and industry, at length was discovered to be a vast indigested heap of contradictory decisions. It was a supplement to the law of Moses, which itself required a supplement. Composed in curt, unconnected sentences, such as would occur in conversation, designed to be got by rote by the students from the lips of their oracles, the whole was at length declared not to be even intelligible, and served only to perplex or terrify the scrupulous Hebrew. Such is the nature of 'traditions' when they are fairly brought together, and submitted to the eye.

"The Mishna now only served as a text (the law of Moses being slightly regarded) to call forth interminable expositions. The very sons of the founder of the Mishna set the example, by pre- 
tending that they understood what their father meant. The work once begun, it was found difficult to get rid of the workmen. The sons of 'the Holy' were succeeded by a long line of other rulers of their divinity schools, under the title, aptly descriptive, of the Amoraim, or dictators. These were the founders of the new despotism; afterwards, wanderers in the labyrinth they had themselves constructed, roved the Seburaim, or opinionists, no longer dictating, but inferring opinions by keen disputations. As in the decline of empire mere florid titles delight, rose the Geonim, or sublime doctors; till at length, in the dissolution of this dynasty of theologians, they sunk into the familiar titular honour of Rabbi, or master!

"The Jews had incurred the solemn reproach in the days of Jesus, of having annihilated the word of God by the load of their traditions. The calamity became more fearful when, two centuries after, they received the fatal gift of their collected traditions called Mishna, and still more fatal when in the lapse of the three subsequent centuries, the epoch of the final compilation, was produced the commentary graced with the title of the Gemara, Completeness, or Perfection. It was imagined that the human intellect had here touched its meridian. The national mind was completely Rabbinised. It became uniform, stable, and 'peculiar.' The 'Talmud, or the Doctrinal, as the whole is called, was the labour of nearly five hundred years.

"Here, then, we find a prodigious mass of contra- 
dictory opinions, an infinite number of casuistical cases, a logic of scholastic theology, some recondite wisdom, and much rambling dotage; many puerile tales and oriental fancies; ethics and sophisms, reasonings and unreasonings, subtle solutions, and maxims and riddles; nothing in human life seems to have happened which these doctors have not perplexed or provided against, for their observations are as minute as Swift exhausted in his 'Directions to Servants.' The children of Israel, always children, were delighted as their Talmud increased its volume and their hardships. The Gemara was a third law to elucidate the Mishna, which was a second law, and which had thrown the first law, the law of Moses, into obscurity." *

The Talmud consists of the Mishna and the Gemara. The former is always placed as the text, to which the latter, as the comment, is subjoined. It contains not only the opinions of the various. Doctors on disputed points, and directions as to whose judgment must be followed, but a multitude of mystical expositions of the law, allegorical stories, and parables, and fabulous histories of persons mentioned in Scripture, written in a style so intensely childish as to be worthy of comparison only with "Jack the giant-killer," or "Puss in boots." But these are mingled with such irreverent and even blasphemous stories, as one shudders to read, and these not only concerning the Lord Jesus Christ, but concerning God whom the authors professed to worship. We may well be content to leave these in

* Genius of Judaism, p. 88, et seq. 
the obscurity that invests them: but our readers may like to see a specimen or two of Talmudical exposition and history, that they may better judge what "blindness" it is that "is happened unto Israel," and how thick the "veil," which "when Moses is read, is upon their heart." And if the perusal of such puerilities excite our contempt, let it excite our sorrow and pity, too, for the blinded nation, which for near two thousand years has been intellectually and morally bound in so vile a chain, and our prayer, that soon, according to the promise, it "may turn unto the Lord," and the "veil be taken away."

"Thou hast ascended on high: thou hast led captivity captive; thou hast received gifts for men ; yea for the rebellious also, that the Lord God might dwell among them." Ps. lxviii. 18. This is expounded of Moses, who, it is said, ascended to heaven by God's command; where, however, the Angels, being jealous of the favour shown him, went about to kill him. But God, aware of their design, complained of their insurrection; on which the Angels remonstrated, that this defiled man ought not to mix among them. God answered that Moses was sanctified. Being silenced on that point, they next complained that the law should have been given to Men, and not to Angels; but were pacified by the rejoinder, that laws were not made for sinless, but for sinful creatures. This encomium so pleased the Angels, that they received Moses with kindness, and communicated to him half their wisdom. Thus heaven and the Angels were robbed 
of their treasures, which is implied in the words, "Thou hast led captivity captive," \&c.

"Prepare thy work without, and make it fit for thyself in the field, and afterwards build thine house." Prov. xxiv. 27. Solomon speaks here of the Law, the Mishna, and the Talmud. To prepare the work without is the Scripture; the fitting it in the field, is the compiling of the Mishna; and the building of the house, is the promulgation of the Talmud.

"There was neither hammer, nor axe, nor any tool of iron heard in the house while it was in building." 1 Kings vi. \%. On the eve of the sabbath God created a worm called Samir, which cleft and polished the stones for the temple by its touch. This unknown Worm was brought to Solomon, say some, by the evil spirit Asmodeus; but others, scandalized at allowing a devil any part in the building of the Temple, assert that Solomon, having found a hoopoe's nest, inclosed the young ones in a glass case; the disconsolate old bird immediately brought this Worm, which broke the glass, and delivered the brood. But it is the opinion of other doctors that Solomon, whose wisdom extended to an acquaintance with the language of birds, asked them where the Worm Samir was : an eagle immediately took wing, and found it in the terrestrial Paradise. It was at once set to work in polishing the stones, whence it came to pass that there was not needed a single stroke of the hammer all the time the Temple was building. The work being accomplished, the Worm was shut up in lead, and 
fed with great care, but perished at the destruction of the Temple by the King of Babylon.

"For only Og King of Bashan remained of the remnant of giants." Deut. iii. 11. The history of a giant was likely to be a favourite subject with such commentators, and their imagination accordingly revels in it. By an ingenious criticism, the above text is explained to mean that $\mathrm{Og}$ was the sole survivor of the antediluvian race of giants, living down to the time of Moses. How he strove to stop the "fountains of the great deep" with his foot, and to cover the "windows of heaven" with his hand, until the bursting waters were made too hot to admit this expedient; how he then kept close to the ark, where the water was cool, wading about in it (for such was his stature that the flood reached but to his ankles); how he sat on the steps of the ark, and was daily fed from the window by Noah, with whom he had managed to ingratiate himself; how he was presented by Nimrod to Abraham; how faithfully he served the patriarch; and how he was rewarded by the throne of Bashan; how Abraham lay in the hollow of his hand; and how he made a favourite easy-chair of the giant's tooth, the Rabbins delight to inform their admiring readers. The death of $\mathrm{Og}$, however, we will quote in detail. "And it came to pass that the wicked $\mathrm{Og}$ saw the camp of the Israelites, which extended three leagues, and said, 'I must bring upon this people a dreadful destruction, lest they serve me as they have served Sihon.' So he went and plucked up a mountain of three leagues in extent, and, 
setting it on his head, intended to cast it upon the camp. But God caused ants to eat a hole in the hill, which fell over his head, and inclosed it. And when he endeavoured to get rid of his burden by casting it from him, he could not move it, for his teeth had grown out so long as to be fastened in the sides of the hollow; and his mouth moved this way and that. Then went Moses and took an axe ten ells in length, and leaping up to a height of ten ells, struck him on the ankle, so that he fell down and died."

These "profane and old wives' fables" are considered to receive a triumphant confirmation from the words of the third Psalm: "Thou hast broken the teeth of the ungodly;" for the text, say the Rabbins, needs correction, and should be read, "Thou hast lengthened the teeth," \&c.!

Such, then, is the literature, the sacred literature of the modern Jews: such is the profound wisdom for the study of which all other learning is despised and denounced! "Our law," says Cardoso, " is our science and our understanding; and truly Israel cares not for human sciences, for uncertain philosophy, empirical medicine, dreaming chemistry. Israel cares not to learn the histories of other nations, nor the chronology of civil events, nor the politics of princes." *

The first commentary on the Mishna was made by the disciples of Judah the Holy, and called the Jerusalem Talmud, either because it was compiled in Judea, or because it was written in the dialect

- Excellencias de los Hebreos, p. 135. 
that was spoken there. At what time this was finished is not correctly ascertained, but probably not before the end of the third century. It did not command universal approbation; for complaints were made of the barbarous dialect in which it was composed, and of the small number of doctors whose decisions it pronounced.

Hence it was thought needful that a new edition of the work should be attempted, and this was undertaken by Rabbi Asa, of the Academy of Sora, near Babylon. He was a man eminent for learning and wisdom, and the execution of this great work cost him forty years of labour. He did not, however, finish it; - that honour was reserved for his disciples, and is supposed to have been accomplished about the commencement of the sixth century. It is known as the Babylonian Talmud; and is held in far greater repute by the learned Jews than its Jerusalem predecessor.

The execution of such a work seems to imply a period of quietness and prosperity; and in such a condition were the Oriental Jews, whose history, as distinguished from that of their Western brethren, we now revert to trace.

The Patriarch of Tiberias found a rival in the East. The homage which he claimed was reluctantly paid, even from the first, by the Mesopotamian Jews, whom freedom from the pressure of the common affliction, and long residence in comfort at a distance from Judea, had in a measure estranged from their Western brethren. But after a while we find them acknowledging the authority of a ruler, 
who governed with scarcely less than kingly splendour, under the title of Prince of the Captivity. The rise of this Oriental power is involved in much obscurity; we cannot trace it with any distinctness before it was embodied in the person of Huna, the contemporary and rival of Judah the Holy. The Galilean Patriarch is even said to have acknowledged the superior authority of Huna, declaring that if the latter were to visit Palestine, he would willingly render him homage. The claims thus made and admitted seem to have principally rested on the assumption, that the Royal line of David, through Jehoiakim, still survived in these Princes of the Captivity.

It was at Babylon that this government was administered; by which is to be understood, not the ancient city of that name, "the beauty of kingdoms, the glory of the Chaldees' excellency," for her desolation had come, as had been predicted;but the city of Seleucia, which, though built at several miles' distance, perpetuated the name and a shadow of the glory of her renowned predecessor. Josephus, Philo, and other ancient writers, have given testimony to the large proportion of Jews who inhabited this populous city, and the neighbouring regions; and the same worldly ease and prosperity, which had originally induced so many of the "Children of the Captivity" to prefer ease in Babylon to poverty in Palestine, had probably continued to mark their descendants under a government for the most part mild and beneficent; so that at the period of which we speak 
the Babylonian Jews were proverbial for their opulence. In the magnificent hyperbole common to the nation and to the age, a Hebrew merchant of Babylon was described as possessing a thousand ships upon the seas, and a thousand cities upon the land.

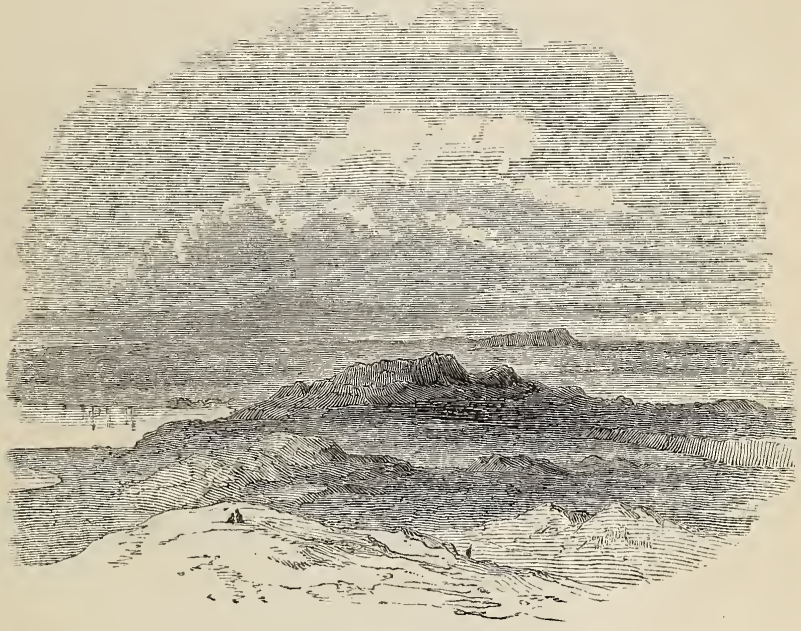

BABYLON.

But the pursuits of commerce, and the amenities of wealth, did not preclude the Eastern Jews from literary eminence. Academies were established among them, the students of which were very numerous; and many of their Rabbis are mentioned who added lustre to the nation by their wisdom and learning. The principal colleges were those of Nahardea, Sora, and Pumbeditha; and the reputation of the last two was considered equal, if 
not superior, to that of Jamnia, or even of Tiberias itself.

In the midst of this wealth and learning the Prince of the Captivity ruled a willing people; the wealthy and the learned uniting to confer his dignity. At his installation, the heads of the colleges, the elders and the populace, assembled in great pomp in the city of Babylon. In a lofty and spacious chamber, hung with gorgeous drapery, sat the claimant of the hereditary honours of the House of David. Here, in a solemn oration, the President of the Academy of Sora exhorted the new Prince to moderation in the use of his power; to humility, reminding him that he was not called to sovereignty, but only to the headship of an exiled and captive people. On the following Thursday he was installed into his office in the synagogue by the imposition of the hands of the learned presidents of colleges, amidst the sounding of trumpets, and the shouts of the people. He was now conducted in great state to his house, where he received the various presents which the wealth and enthusiasm of the people poured in upon him. On the Sabbath the persons of distinction met before his house, when, placing himself at their head, covered with a silken veil, he marched in procession to the synagogue, where psalms and hymns of thanksgiving and benediction were chanted. After this he read out of the Book of the Law, and addressed the multitude, whom he exhorted to charity, himself setting the example by liberal almsgiving. The ceremony having been concluded with prayers and 
mutual benedictions, the Prince was escorted to his palace, where a sumptuous entertainment was made for the heads of the people.

The Prince of the Captivity affected the state of an Eastern despot. He lived in strict seclusion, never going abroad except when he visited the academies, where he was received with reverence, the students all rising on his entrance, and remaining standing till he graciously commanded them to resume their seats. His court was modelled on that of the Persian monarch, whom he owned as his lord; officers, councillors, and cupbearers, waited on him, and eminent Rabbins exercised his delegated authority over the various districts of his government.

It appears to have been customary that the new Prince, soon after his inauguration, should visit in state the Parthian (or afterwards the Persian) monarch, whose subject he was. On such occasions he displayed his humility and his pride. The King marked his favour to his guest by sending his own chariot for him; but the Prince durst not accept the distinction, preferring to show his respect and indicate his dependence, by walking behind the empty vehicle. He wore a magnificent vest of cloth of gold; a guard of fifty men preceded him; and every Jew who met the procession was bound in honour to fall into the train, and accompany his Chief to the royal palace. At a certain distance the eunuchs met him, and conducted him to the throne of the King; while an officer, marching by his side, distributed largesses of gold and silver 
to the crowd. When he came into the presence of the sovereign, he prostrated himself in humble obeisance, after which the eunuchs raising him, seated him on the left hand of the throne, when complimentary salutations and inquiries merged into the discussion of such matters as required consideration.

The Prince of the Captivity maintained his authority during many centuries; surviving alike the decadence of the Parthian power, and the restoration of the ancient Persian dynasty in Artaxerxes, or Ard-shirr, and the subjugation of the country by the Arabs in the early part of the career of Mohammedan conquest. A fatal blow was struck at his dominion in the eleventh century, when the famous academies were closed, and great numbers of the disciples were compelled to flee to the West, and particularly to France, where they taught for some years with great reputation. The increasing severity of Mohammedan tyranny gradually destroyed the authority of the Oriental Prince, and the last trace of his existence which history has preserved, is the lingering title, with scarce a shadow of power, which was found by Benjamin of Tudela, when he travelled into the East, in the twelfth century. 


\section{CHAPTER XII.}

\section{CHRISTIANITY.}

\section{A. D. $313-479$.}

THE implacable hostility of the Jews to the "sect of the Nazarenes," as they termed the Christian

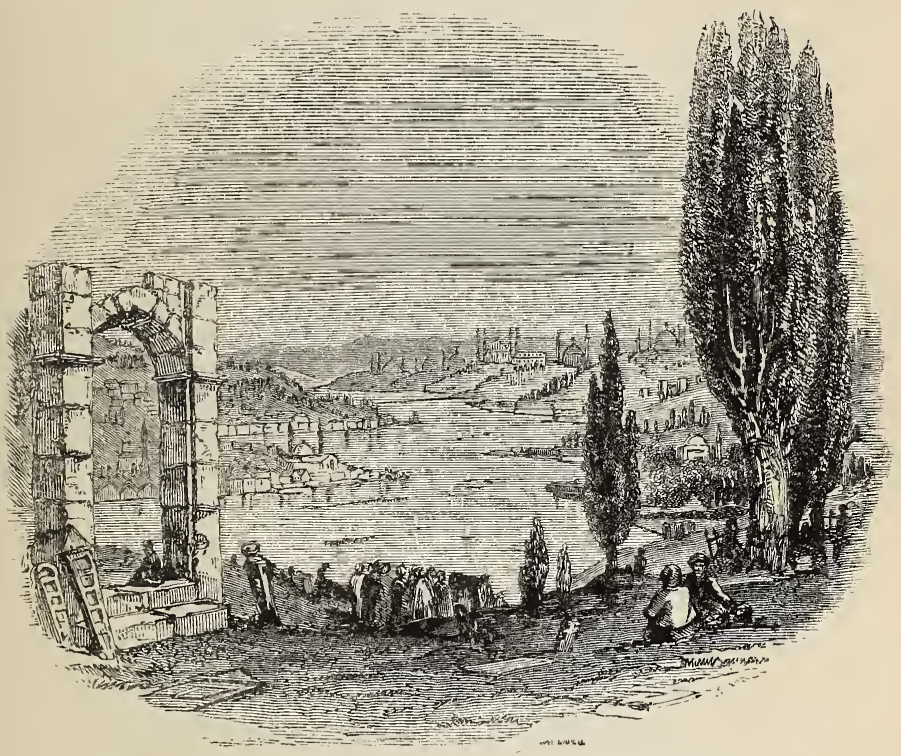

CONSTANTINOPLE.

Church, was neither assuaged by reason, nor diminished by time; and as they watched from age to age the Christian religion winning its widening 
way, like a giant "conquering and to conquer," and, in spite of all the persecuting fury of Pagan emperors, gradually extending over the world, they must have felt the bitterness of impotent hatred, and disappointed hope. But this bitterness must have reached its height, when, on the triumph of Constantine, Christianity became the religion of the throne and of the empire; and the painful remembrances of the iron hand of Rome probably yielded to still more rancorous feelings, associated with the seven-hilled city of the East, the rising metropolis of the Christian world.

Unfortunately the Jews had no monopoly of intolerance; those who bore the Christian name were in many cases animated by an equally virulent spirit. The meekness and gentleness which had marked the early disciples of Jesus, meeting hatred with love, and overcoming evil with good, had been long waning; and the holy ardour of him who could solemnly testify to "great heaviness and continual sorrow of heart" for his Israelitish brethren, found few imitators. There was not wanting, indeed, zeal for the conversion of the obdurate Jew; but it was a zeal mainly "after the flesh;" earthly were the objects, earthly the motives, and most earthly the weapons of the warfare which the Christianity of that age waged against Judaism. Instead of reasonings out of the Scriptures, and a living, powerful testimony to the resurrection and exaltation of the crucified Saviour, the mighty weapons of apostolic days - the disputants of the degenerate age that we are discussing, trusted to 
the power of mouldering relics, lying legends, and pretended miracles; or, when these failed, alternately essayed the persuasive force of offered emoluments, or of stripes and wounds.

The secession of any member of their body was looked upon by the Jews as an unpardonable offence, to be washed out only in the blood of the offender. It is a maxim of the Mishna, that whoever renounces the foundation, that is the Jewish faith, is to be killed; and though the power of life and death was not now in their hands, yet it appears that, whenever they had the opportunity, they did not hesitate to slay converts from their number, by stoning, burning, or drowning. This remorseless virulence occasioned some severe edicts to be promulgated by Constantine, ordaining that those proved guilty of such an offence, should be burnt alive, with all their accomplices; and probably gave occasion for other measures of repression. Chrysostom affirms, indeed, that Constantine cut off the ears of the Jews, and dispersed them among the cities of the empire, for having attempted to repossess Jerusalem; and Eutychius adds, that the same emperor compelled them to be baptized, and to eat swine's flesh at the Passover. In general, however, the edicts of this prince, though severe, seem not to have been tyrannical. Toleration was then unknown. Christians were forbidden to profess Judaism, on pain of arbitrary punishment; Jews were prohibited from circumcising their slaves; and if any accused his master of having performed this rite upon him, or if he made a profession of Christianity, in either 
case he was emancipated from his bonds. Eusebius, however, goes so far as to say, that the Jews were forbidden to buy or to keep Christian slaves, assigning as a sufficient cause, the unreasonableness that those who had been ransomed by the blood of Christ, should be in bondage to his murderers.

The office of decurion, a post of burdensome service and of no honour, the Jews had hitherto been spared; but they were now no longer allowed the privilege of exemption. This enforcement of an unpleasant duty, while it doubtless indicated that the emperor's mind was not particularly favourable to his Hebrew subjects, cannot be considered as tyrannical; and it proves incidentally, that they were recognised as possessing the rights of citizenship, with its responsibilities.

The spirit of the Church was far less tolerant than that of the State: the haughty councils of the clergy often prevailing against the more moderate tone of the imperial government. A painful example of persecuting bitterness is afforded by the acts of the Council of Eliberis (Elvira), in Spain, which was held just before the commencement of this reign. In that country Jews and Gentiles had lived together in amity and good-will, enjoying the amenities of social intercourse without restraint. But the Council forbad this intercourse, and that by a stroke so suddenly severe, that excommunication was the punishment for any one guilty of eating with a Jew; a terrible and unmerciful decree. To this they added another, still more absurd, if less oppressive. The Jews were in that country 
largely engaged in agricultural occupations, a sure token that they had been for some time allowed to live in quietness and comparative prosperity. In the festivities attendant upon the harvest, and at other rustic rejoicings, the Jewish peasants had been accustomed to mingle their blessings and thanksgivings for earthly gifts, with those of their Christian brethren, and to supplicate a continuance of common mercies. It would seem to require an invidious eye to detect harm in this; but the Council of Eliberis forbade the possessors of lands to suffer their fruits to be blessed by the Jews, because their blessing frustrated that of the Christians. As if the prayers of men were a sort of spell or charm, one set counteracting another; and as if the Holy and Wise God could be made to act blindly, by a sort of incantation, without any reference to the desire and faith of those who asked him for his blessings, and without any regard to His own purposes! How much darkness, we may observe, had even thus early overshadowed the Church, when such ignorance of God was displayed in solemn council! The edict was issued; and excommunication was again the penalty of disobedience.

It is a common result of injury that it provokes injury; mutual affronts are succeeded by heightened affronts, until each party strives to do the other all the harm in its power, and exasperation attains a high pitch. It cannot be pretended that the fiery spirit of the Jew was disposed tamely to submit to persecution; long ages of grinding tyranny, while he has lain crushed beneath the iron heel of the 
Gentile, have been required to break his pride, and bend the "iron sinew" of his neck; and even now the spirit but sleeps. At the time of which we write, they were ready to make common cause with any ally who was hostile to the Christians. Combining with the Magi, they stirred up a furious and protracted persecution in Persia; one of the first martyrs of

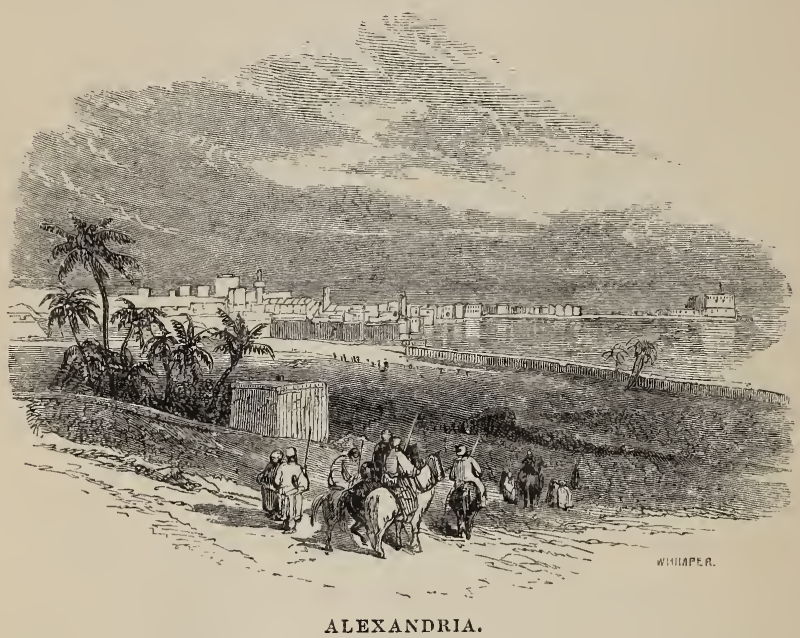

which was Ustazades, the chief minister of the State. And in the violent disputes which were splitting the whole Church into rival and hostile factions, the Jews invariably sided with the Arians; joining the heretical party, in particular, in those bloody tumults and dreadful outrages at Alexandria, which disgraced the name of religion, when the renowned Athanasius was, for the third time, expelled from his archiepiscopal see by the infamous George of Cappadocia. 
This conduct could scarcely constitute an offence in the estimation of the Arian emperor, Constantius; but a renewed attempt to possess themselves of Palestine, counterbalanced any favour that the Jews might have earned as religious partisans. Taking advantage of the revolt of Magnentius in the West, and of the inroad of the Persians in the East, they raised the banner of rebellion in the city of Dio-Cæsarea, a place which, under the name of Sepphoris, had been one of the renowned seats of Rabbinic learning, and was at this time inhabited solely by Jews. The insurrection was quickly put down, and the city demolished; their turbulent attempt producing no other result than exposing them to new severities and inflictions. The incensed emperor repeated and enforced, with fresh rigour, the enactment of Adrian, prohibiting the setting of the Jewish foot within the walls of Jerusalem; he forbade, under severe penalties, the conversion from Christianity to Judaism, and the possession of Christian slaves; to circumcise one of Christian descent was made punishable with death; as was also the marriage of a Christian woman by a Jew, Finally, Constantius burdened his Hebrew subjects with fines and exactions, and was meditating more grievous taxes, when he died.

The accession of Julian, apostate as he was from the profession of the abhorred religion, must have elated the hearts of the Jewish people with joy, and eager hope. His attachment to the herd of idolgods that filled the fanes of ancient Greece and Rome had no more sympathy with the worship of 
Judaism than with that of Christianity, but his hatred to the latter prompted him to embrace any alliance against it. The rivalship of Judaism to Heathenism was feeble and despicable, compared with that of Christianity; and to restore the dominion of idolatry would, indeed, have been a triumph of which the Apostate might be proud. The new emperor proceeded to court the smiles of his turbulent subjects, and secure their suffrages. He annulled the oppressive taxes, and repealed the severe laws, of his predecessors, put the Jews on a level with the most favoured citizens, and wrote a letter in the most condescending style to the Patriarch of the West, whom he addressed by the term "Brother." In this epistle he expresses his good will to his Hebrew subjects, his sympathy and condolence with them for their late sufferings, and his desire to rebuild their city and temple, which he would make his metropolis, and where he would join with them in worshipping the great God of the universe, as soon as he had put a prosperous termination to the Persian war.

The Jews were not slow to avail themselves of this gleam of imperial sunshine. They assembled in a tumultuous manner in many cities of Judea and Syria, insulting the Christian population. In Damascus, one of the oldest cities in the world, which history traces as a place of note as early as the era of Abraham, and which has survived all the mutations of time down to the present day, - they committed great excesses, levelling with the ground two Christian churches, one of which continued in ruins 
in the time of Ambrose. In Egypt similar outrages were perpetrated, and the finest church of Alexandria was demolished.

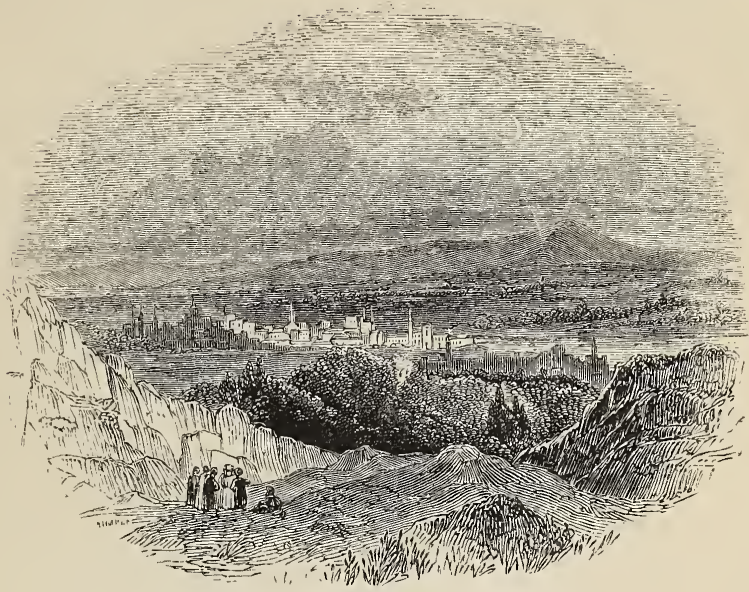

DAMASCUS.

The emperor hastened to show that he was in earnest, and that his designs were not to evaporate in protestations. The restoration of the Temple at Jerusalem was not a mere unmeaning flourish, but a deep and settled purpose of his heart, entertained with the object of frustrating the accomplishment of the Sacred Prophecies. The fall and dispersion of the Jewish nation, the Apostate well knew, was an unanswerable proof of the divinity of Him, who claims the knowledge of the future as his own prerogative; * and who had stood on the Mount of Olives and denounced the desolation of the Temple, and the trampling down of the Holy City, until " the

* Isa. xli. 22,23 ; xlii. 9 ; xliii. 9 ; xliv. 7 ; xlv. 21 ; xlvi. 9,10 . 
times of the Gentiles should be fulfilled," and men should see the glorious advent of the Son of God.

And they shall fall by the edge of the sword, and shall be led away captive into all nations: and Jerusalem shall be trodden down of the Gentiles, until the times of the Gentiles be fulfilled. Luke xxi. 24.

Immediately after the tribulation of those days shall the sun be darkened, and the moon shall not give her light, and the stars shall fall from heaven, and the powers of the heavens shall be shaken : And then shall appear the sign of the Son of man in heaven: and then shall all the tribes of the earth mourn, and they shall see the Son of man coming in the clouds of heaven with power and great glory. Matt. xxiv. 29, 30 .

Other prophecies had connected the removal of the desolations of Israel with a spirit of mind far different from that which now animated them, and these Julian, doubtless, well knew ; and knew, also, that to restore the Jewish polity to its place among the nations of the earth in impenitence and unregeneracy, would be to give the lie both to the threatenings and promises of God.

Upon the land of my people shall come up thorns and briers, yea, upon all the houses of joy in the joyous city: because the palaces shall be forsaken; the multitude of the city shall be left; the forts and towers shall be for dens for ever, a joy of wild asses, a pasture of flocks; until the Spirit be poured upon us from on high, and the wilderness be a fruitful field, and the fruitful field be counted for a forest. Then judgment shall dwell in the wilderness, and righteousness remain in the fruitful field. And the work of righteousness shall be peace; and the effect of righteousness, quietness and assurance for ever. And my people shall dwell in a peaceable habitation, and in sure dwellings, and in quiet resting-places. Isa. xxxii. 13-18.

For I would not, brethren, that ye should be ignorant of this mystery, lest ye should be wise in your own conceits; that blindness in part is happened to Israel, until the fulness of the Gentiles be come in. And so all Israel shall be saved: as it is written, There shall come out of Sion the Deliverer, and shall turn away ungodliness from Jacob: for this is 
my covenant unto them, when I shall take away their sins. Rom. xi. $25-27$.

Before his departure for the Persian war the emperor issued his proclamation for the rebuilding of the Temple on Mount Moriah; exhorting the Jews to labour ardently in the undertaking, for the expenses of which a vast sum was granted from the public exchequer. An immense quantity of materials, stone, brick, lime, timber, iron, and brass,was prepared, and the conduct of the work was entrusted to the emperor's intimate friend Alypius, formerly lieutenant in Britain, who was empowered to command the aid of the governor of the province. The Jews responded to the call with alacrity and enthusiasm ; every part of the empire sent contributions of men, or money, or materials, to the spirit-stirring enterprise. Happy was he who, freed from encumbrances, could devote his talents, his labours, and his life, to so patriotic a design. "In this propitious moment the men forgot their avarice, and the women their delicacy; spades and pickaxes of silver were provided by the vanity of the rich, and the rubbish was transported in mantles of silk and purple. Every purse was opened in liberal contributions, every hand claimed a share in the pious labour: and the commands of a great monarch were executed by the enthusiasm of a whole people." *

In the haughty delirium of the transient dream, the Jews, assembled in crowds in the City of their fathers, counted the work as already accomplished, indulged themselves in extravagant demonstrations 
of triumph, and heaped the extremity of scorn and invective upon the Christians, whom they tauntingly asked to share in so glorious an enterprise. Some of them even blasphemously addressed the Apostate as the Messiah of God.

Meanwhile the faithful people of God looked on in silence and dismay; for though many, doubtless, stayed themselves on the unchangeable promises of Jehovah, and confidently announced (as did Cyril, the pious bishop of Jerusalem, from the prophecies of Daniel) the utter failure of the scheme, yet surely it must have been a sore trial to faith, "a day of trouble, and of rebuke, and of blasphemy." But the Lord was "above the water-floods;" and the language of the second Psalm was as applicable to this emergency as it had been of old.

Why do the heathen rage, and the people imagine a vain thing? The kings of the earth set themselves, and the rulers take counsel together, against the LorD, and against his Anointed, saying, Let us break their bands asunder, and cast away their cords from us. He that sitteth in the heavens shall laugh : the LoRD shall have them in derision. Then shall he speak unto them in his wrath, and vex them in his sore displeasure. Yet have I set my King upon my holy hill of Zion. I will declare the decree : the LoRD hath said unto me, Thou art my Son ; this day have I begotten thee. Ask of me, and I shall give thee the heathen for thine inheritance, and the uttermost parts of the earth for thy possession. Thou shalt break them with a rod of iron; thou shalt dash them in pieces like a potter's vessel. Be wise now, therefore, $O$ ye kings; be instructed, ye judges of the earth. Serve the Lord with fear, and rejoice with trembling. Kiss the Son, lest he be angry, and ye perish from the way, when his wrath is kindled but a little. Blessed are all they that put their trust in him. Ps. ii.

And now the work was begun, and impatient hands had laboured in digging out the accumulated rubbish, and in clearing the excavations, and the 
new foundation was about to be laid, amid the shouts of taunting unbelievers, - when God interposed for the honour of His Holy Name. Not a stone of that edifice was to be laid. On a sudden terrible globes of flame came bursting forth from the bowels of the mountain with irresistible force and deafening reports, scorching and stunning the affrighted workmen, and compelling them to flee for their lives; and these explosions were reiterated from time to time, as often as the builders attempted to renew their labours; until at length, blasted and blinded in the presumptuous attempts, they were reluctantly compelled to abandon the undertaking. The Christian fathers have recorded other accessory circumstances of wonder; but the above statement rests on the unexceptionable testimony of a Pagan historian, Ammianus Marcellinus, who had the best opportunities for knowing the truth, and who cannot be accused of interested perversion.

The haughty Apostate did not long survive the ignominious failure of his insane attempt. The news, however, reached him in his unfortunate Persian campaign, and, doubtless, helped to extort that bitter confession of his dying moments, "O, Galilean, thou hast conquered!"

The incidents of which we have been speaking are briefly but beautifully embodied in the following lines from the "Lyra Apostolica :"-

"The foes of Christ are gathering, sworn to build

Where He had sworn to waste and mar;

Plummet and line, arms of old Babel's war,

Are ready round Moriah's field.- 
But the clouds that lightning breathe

Were ready too,

And, bursting through,

Billows from the wrath beneath,

For Christ and for His seers so keenly wrought,

They half subdued to faith the proud man's dying thought."

From this time until the subversion of the empire, we find little prominence awarded to the Jews in history, except that the contentions between the Church and the Synagogue became more frequent and more virulent, while the State, which commonly adhered to moderate counsels, vainly endeavoured to assuage the fury of religious zeal. The condition of the professing Church had already greatly degenerated from apostolic times, and was continually growing worse: the great heresies with which that age was so rife, had produced, in addition to the direct defilement of their own pernicious doctrines, all the indirect, but not less noxious, fruits incident to perpetual disputation; a spirit of contention, of furious intolerance, of sanguinary persecution, prevailed amongst all parties; every city was divided into factions who lived in perpetual feud; every theologian was a warrior; and discussions as to the doctrines truly inculcated by the blessed Lord Jesus and his Apostles were carried on with fire and sword. The schism of the Donatists, originating in faction and in contention for worldly power, was the occasion of thousands of so-called Christians perishing by the hands of each other. The Arian heresy and the controversies issuing from it produced results similar, and of much longer duration. The tone and temper of mind induced by such a condi- 
tion of strife needed not occasions of showing itself. So fierce and deadly was the animosity that habitually prevailed, so ready were men to appeal to force, that the election of officers of the Church, and particularly the consecration of bishops, was often the occasion of sanguinary strife, and mutual slaughter.

It is not surprising that those who so fiercely contended among themselves on theological questions, had but little tolerance for the Jew. Tumultuous crowds of insensate people, headed by some bigoted churchman, would frequently assemble, and, proceeding at once to the synagogue, begin to inflict summary justice on the enemies of Christ, as if they had a commission to "devour the adversaries." Not a little trouble was caused the emperor by these commotions, which he was, in general, powerless to repress. We shall cite a single instance, which occurred in the reign of the wise and virtuous Theodosius.

In the town of Callinicum, in the eastern province of Osroene, the prefect had permitted the Jews to build themselves a synagogue, in opposition to the wishes of the Christian inhabitants, who had petitioned against it. The bishop of the place having stirred up the rabble, put himself at their head, and marching to the new edifice set it on fire, and burnt it to the ground, as well as a chapel belonging to some heretics. The Jews appealed to the justice of the governor, who ordered the persecuting prelate to rebuild the synagogue, or pay the specified damages. $\mathrm{He}$ would do neither; even 
though the emperor confirmed the decree of the governor.

The affair came to the ears of Ambrose, the fearless and faithful archbishop of Milan; who immediately took up the cause of the insurgents; and it is a painful evidence of the state of public opinion

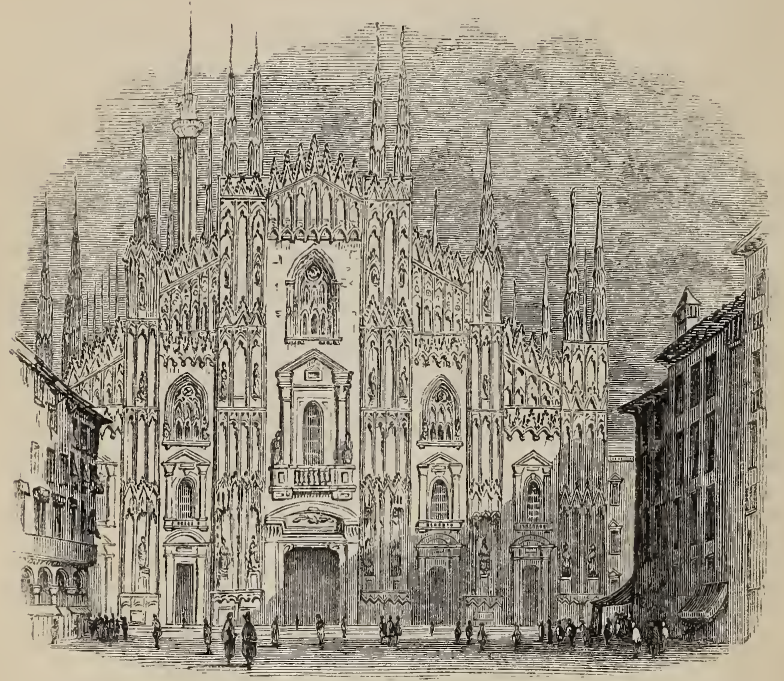

MILAN CATHEDRAL.

in the church, that a man, ordinarily so good and wise, should so little understand the principles of common justice and mercy. The emperor happening to be at the time in Milan, the archbishop addressed to him a bold reproof, censuring his edict in no measured terms. He affected to consider that act of simple equity, as a wicked persecution of the Christian church, which he represented in tears, 
suffering under the triumphs of infidel Jews. The burning of the synagogue he affirmed to be a thing worthy of being gloried in; nay, he asserted, by a sort of legal fiction, that the outrage at Callinicum was his own act, since he heartily concurred in it; demanded, how the emperor could dare to issue such a command, or expect that a Christian bishop would assist in the erection of so vile and impious an edifice as a synagogue; and intimated that to persist in so wicked a course would be alike fatal to the emperor's hopes, and to his reputation.

Even the influence of Ambrose could scarcely prevail to efface from the conscience of Theodosius the rules of moral rectitude; but the archbishop was inexorable; nor would he permit his participation in the eucharist, while he remained at Milan, without a solemn and definite promise of entire immunity to the offending bishop. The pride and power of the monarch bowed before the authority of the prelate: Theodosius gave the promise, and kept it.

The resentment of the Jews against the contempt and hatred of their opponents found vent in a singular manner, when no other opportunity presented itself of avenging themselves. The feast of Purim, instituted in memory of the national deliverance from the malice of Haman, as recorded in the Book of Esther, has not unfrequently been celebrated with bacchanalian orgies more befitting the worship of an idoldemon, than a thanksgiving to Jehovah. On these occasions it is a point of duty to heap indignities, abuses, execrations, blows, and all sorts of contumelies on the name and figure of the abhorred Agagite ; 
as well as to drink the intoxicating cup to such a degree of insensibility, that the bewildered senses can no longer detect the difference between "Cursed be Haman!" and "Blessed be Mordecai!" Of course at such times the character of the fury would take its colour from any strong passion or emotion, with which the public mind might be imbued; and it is no wonder that, at the time of which we write, the Feast of Purim was made the vehicle of much that was outrageous and offensive to Christians. Under the similitude of Haman, they represented Christ; and the gibbet on which they were accustomed to hang the effigy of their enemy, they now made in the form of a Cross; and suspended the image, in the posture generally appropriated to that which was now becoming the object of idolatrous adoration. The smart of personal insult would add pungency to the indignities, with which the infuriated and intoxicated Jews would avenge the old and the new quarrel, venting their impotent malice at once upon Haman and Christ, upon the Amalekites and the Nazarenes; and blasphemies would be uttered, which might make the ears of those who heard to tingle.

Accordingly we find these scenes becoming the occasions of furious collision between the rival parties; synagogues and houses were burned or pulled down, blood was shed, and life was sacrificed; so that the authority of the state was needful for the abolition of scenes so disgraceful, and for the preservation of the public peace.

Sometimes the maddened Hebrews proceeded to more dreadful extremities. At a town between 
Chalcis and Antioch a party of Jews began to mock and blaspheme the name of the Lord Jesus, and at length erected a cross in the public street. Having caught a Christian child, they fastened him to the wood, and scourged him to death. The horrible outrage provoked a sanguinary conflict, which was with difficulty quelled at the time, and left a rankling wound in the memory of the inhabitants. The revenge soon came; the inhabitants of Antioch rose in a body, and plundered a synagogue, dedicating the booty to the service of the church. The Jews, at this time unoffending, appealed to the emperor Theodosius the Second; who, as his predecessor had done, commanded restitution of the edifice. But the celebrated Simeon Stylites interposed as Ambrose had done before, and the offenders were securely shielded from the just consequences of this violent sort of retaliation.

That there were many exceptions to this cruel and persecuting spirit we have no doubt; and that on both sides. Meekness and kindness will commonly beget confidence and gratitude. It is recorded that the good Hilary had made himself so generally beloved by his kind and gentle spirit, that when he died, the Jewish inhabitants of Poictiers assembled at his funeral, to pay his remains a tribute of affectionate respect, and voluntarily chaunted their mournful psalms of lamentation for the decease of the Christian bishop.

It was, perhaps, a consequence of the hostility that was cherished between the Jewish and Gentile races, that the study of the Hebrew language was 
almost entirely neglected by the Christian fathers. The Scriptures of the Old Testament, "the Law and the Prophets," that mighty weapon in the great controversy, the Doctors of the Church were able to use only through the medium of a translation. Jerome was the first who ventured to unlock the treasures of the ancient Hebrew tongue; and the estimation in which his boldness was held both by his contemporaries and himself, sufficiently shows the low state of learning common in that age. Augustin, though in other respects little partial to this father, considers him a prodigy of learning, because he had mastered three languages. Another writer, in the extravagance of his encomium, attributes to Jerome an acquaintance with the languages of the Greeks, the Hebrews, the Chaldeans, the Persians, the Medes, the Arabians,--when, having probably exhausted his geography, he sums up in one word, "and the tongues of all nations." Yet it does not appear that his knowledge of Oriental literature extended beyond the Hebrew.

The authority of the Patriarch of the West, which had subsisted for nearly three centuries, seems to have become extinct in the reign of Theodosius. It had long been waning; and the Jews had gradually been accustoming themselves to appeal rather to the civil tribunals of the empire than to a spiritual jurisdiction, which existed only by their consentaneous submission. Honorius, by prohibiting the customary tribute to be sent from Rome, diminished greatly the Patriarch's resources; and Theodosius, by depriving him of the honorary title of Prefect, which 
had been given him by the preceding emperors, put an end to his authority.

Many of the proud ones of the earth, both men and nations, have been employed as the sword wherewith the Lord of Hosts has from time to time chastised His sinning people. Egypt, Philistia, Edom; Assyria, Babylon; Antiochus, Pompey, Crassus ; all had a work to do against God's heritage : they did it without pity or mercy; Rome came last, inflicting a punishment to which, both for severity and duration, the former visitations were as nothing.

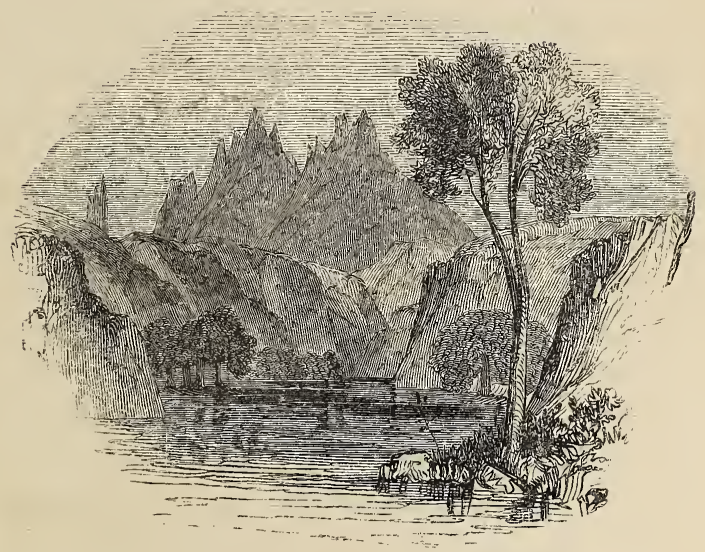




\section{CHAPTER XIII.}

THE GOTHIC DOMINION.

$$
\text { A. D. } 479-629 \text {. }
$$

THE generally peaceful and prosperous condition of the Jewish people at the overthrow of the Western Roman Empire, is thus described by M. Depping. "The position of the Hebrew nation was at this period sufficiently advantageous. Their public worship was respected; full liberty was allowed them in the ceremonies and observances of their religion; they were permitted to observe all the national customs; the jurisdiction of their tribunals in all cases except those which extended to life and death was confirmed: and even criminal cases were not unfrequently decided by them, with the tacit concurrence of the imperial judges. With few exceptions, the Jews stood on the same level as the other subjects of the empire; the chief dignities of the state, and military service, being alone denied to them. The profession of the law, the pursuit of literature, domestic and foreign commerce, and the various occupations of industry, all lay open to them, in which, if we may judge from the jealous tone of their Christian contemporaries, whose writings allude to their habits, they manifested the same ardour 
and perseverance that have always so signally marked their national character." *

During the reign of Odoacer, the first Barbarian king of Italy, we find no special allusion to the condition of the Jews. They doubtless suffered in the common misery, which, like a flood, had inundated the Western Empire, and which was then at its height; but the accession of the wise and politic Theodoric, a prince alike eminent in the arts of war and of government, began to restore a more fourishing condition to the wasted and almost denuded provinces. Though, unhappily, an Arian in his religious profession, the Gothic king was mild and tolerant to the consciences of his dissentient subjects; and the Jews shared with the orthodox in the advantage of his liberality. He remonstrated with the former, indeed, on account of their excessive covetousness, and their neglect of their eternal happiness; but he protested against any sort of coercion applied to men's consciences, as it made them hypocrites, and not converts. The furious zeal which animated the ecclesiastics of that day,-untaught even by his moderate indulgence towards themselves,-he repudiated and punished. At Rome, Ravenna, Milan, and Genoa, the mob, inflamed by blind party-spirit, which abused the name of religion, made assaults on the synagogues, and either burned or otherwise destroyed them. The persecuted Hebrews had recourse to the known equity of the Gothic monarch, and were not disappointed of redress. He severely reprimanded the Senate of Rome for permitting so odious

* Les Juifs dans le Moyen Age, 17. 
and dangerous an outrage as the firing of the synagogue, the flames of which might have involved the ruin of the city. "A legal inquiry was instantly directed; and as the authors of the tumult had escaped in the crowd, the whole community was condemned to repair the damage." *

The arms of Justinian proved fatal to the Barbaric supremacy in Italy. This great prince united the zeal of a polemical theologian with the talent of a legislator. Procopius affirms that he was so continually taken up with churchmen in private, for determining niceties in matters of faith, that he spent time among them, which he should have devoted to the secular affairs of his government. We are not, therefore, surprised to find this emperor revoking the tolerant laws of former sovereigns, and attempting to enforce upon the Jews an outward conformity to Christianity by pains and penalties. The historian just cited informs us that Justinian prohibited their celebration of the Passover on any other day than that on which the Church kept Easter; which was, in effect, a prohibition of it altogether, except by a rare coincidence; for the Law had fixed that feast to the 14th day of the month Abib, which the Jews had no power to alter. But the more effectually to deprive them of this great national observance, he amerced with heavy fines all those who should eat the paschal lamb.

The same emperor farther humbled his Hebrew subjects by forbidding the magistrates to receive the testimony of a Jew against a Christian, and by

- Gibbon, Dec. and Fall, c. xxxix. $§ 19$. 
depriving them of their natural right of making bequests and donations of property. Some tyrannical edicts seem to have had a local application, of which an instance occurs with respect to Africa; for on the occasion of the Council of Carthage petitioning for the restoration of the Church estates, which the Vandals had sequestered, the emperor ordained, among other intolerant decrees, that the synagogues should be taken from the Jews and used as churches, and that the poor deprived Hebrews should not even meet in caves, nor perform their worship in any place; defending his interference on the ground that the religious acts of unbelievers must themselves be impious.

It was always a part of the punishment of this high-minded people, that they heightened and increased their own misfortunes. Their indomitable pride prompted them to attempt an avenging of the affronts heaped upon them, even when successful resistance was utterly hopeless; and thus, "kicking against the pricks," they brought down upon their devoted heads a visitation sevenfold sterner than before. Uninstructed by former disappointments, the persecutions of Justinian provoked the unhappy Hebrews to new revolts, with but the old results.

In the year 530, a false Messiah, named Julian, appeared in Palestine, and incited the people to rise in arms. Great numbers flocked to his standard, with that readiness which had been foretold by the Lord Jesus,* ravaged the country with fire and

* Matt. xxiv. 5 ; John v. 43. 
sword, destroyed churches, and made a great slaughter of the Christians, directing their animosity principally against the clergy. The opportune arrival of the imperial troops, however, turned the tide of affairs; without experience or military conduct, the immense horde of undisciplined assassins fell an easy prey to the soldiers. The blood of a hundred thousand persons is said to have signalized this meaningless insurrection.

About twenty-five years afterwards another sanguinary tumult broke out in the city of Cæsarea. The Samaritans and the Jews, though hostile to each other, had been united in the intolerant decrees of Justinian, and now merged their mutual differences in a common desire for vengeance. They razed the churches to the ground, murdered the governor of the city in his palace, and committed dreadful ravages. These excesses provoked a severe revenge. The emperor sent Adamantius to bring the offenders to justice; who confiscated the estates of the opulent, slew many, and exiled many more. The execution of the sentence is said to have been so bloody, that it made all the Jews of that country tremble.*

Grateful for the security and peace which they had enjoyed under the shadow of the Barbarian kings, the Jews were among the most resolute opponents which the imperial arms encountered in Italy. When Belisarius, the able general of Justinian, after his successful campaigns in Africa and Sicily, invaded the Italian shores, the fair city of Naples

* Basnage, xxi. 9. 
first arrested his victorious course. A large party among the inhabitants were for submission, and the terms of capitulation would have offered no delay to the conqueror, but for the enthusiasm and courage of the Jews, who were numerous and wealthy. They exhorted their fellow citizens to maintain a desperate resistance, assuring them that they should want

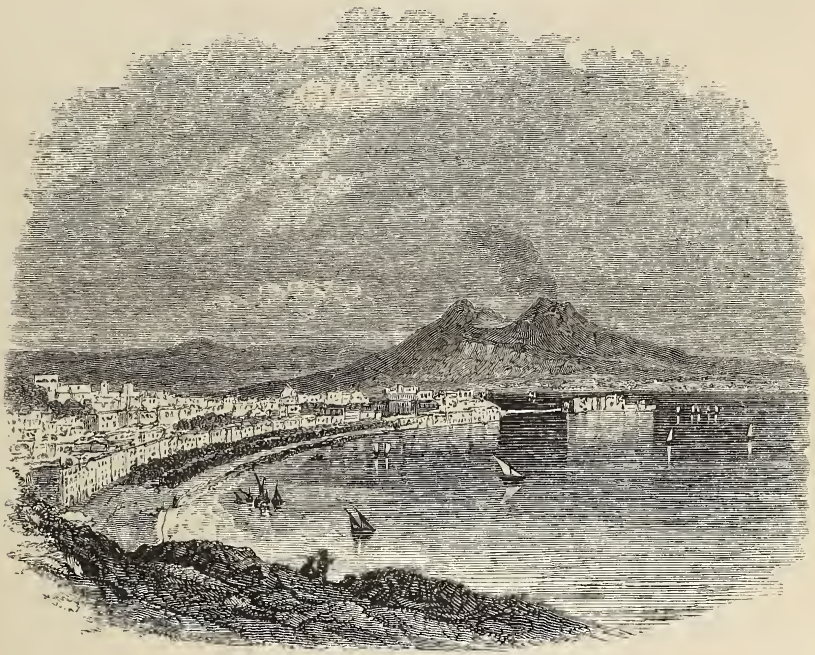

NAPLES.

neither provisions, money, nor ammunition, during the siege. The garrison, thus encouraged, presented a bold front to the invader, and for twenty days defended the city with the greatest vigour. The Jews themselves guarded the quarter next the sea, where they fought with the courage of despair ; well knowing that an inexorable vengeance would be taken 
upon them, if unsuccessful, as having been the inciters of the resistance. The furious sallies, for which the Jewish warrior was distinguished, greatly thinned the Roman ranks, and Belisarius had to lament the loss of many of his bravest soldiers and officers. At length artifice accomplished more than skill or force; the discovery of a secret passage made the besiegers masters of the city, and enabled them to glut their fury by a sanguinary revenge. Belisarius is reported to have made an effort in behalf of mercy; but it seems to have produced little effect: and in the indiscriminate massacre which ensued we may be sure that the unhappy Jewish inhabitants drank again the cup of misery to the full.

The Papacy, which was to be so terrific a desolator of the poor broken people of Israel, did not manifest its persecuting rage at once. Indeed it at first wears the aspect of moderation, curbing the violence and softening the acerbity of polemical strife; for Gregory the Great exhibits a tolerant spirit towards the Jews, that cannot fail to engage our admiration; a spirit as unwonted among the theologians of that age, as it is pleasing.

The maxims of this wise pontiff are worthy of being recorded. "The Jews must be called to the unity of the Faith by gentleness, by persuasions, and charitable advices. Violence is likely to disgust those whom gentleness and charity allure. Menaces and terror stop those whom the oft-repeated impressions of God's holiness had shaken. The true method to convert them is not to make them fear 
us, by carrying severity to excess, but to induce them to come and hear the word of God."

Conformable to these maxims was the equitable and impartial administration of Pope Gregory. On many occasions he repressed the intolerance of other ecclesiastics, or supported such as were just against the blind zeal of the populace. Nor was he dazzled by wholesale proselytism. An abbess in Sicily, desirous to signalize her zeal, wrote to the Pope that a great multitude of wealthy Jews desired to enter the church. But the dispassionate prelate warned the zealous abbess that she should not be too hasty; that these catechumens would need to be carefully instructed before they could be baptized; and that even the most impatient of the converts would do well to prove the sincerity of his change by a trial of at least forty days. Thus the zeal and the avarice of the abbess were at once discouraged.

Yet at other times this Pope was not averse to employ very earthly incentives to conversion. $\mathrm{He}$ thought it lawful to try the persuasive power of money, in subduing the rigid temper of the unbelievers; for though he acknowledged that faith could not be produced by bribery, he hoped that by the hypocritical submission of the parents, the children might be brought under the power of the word, and thus become converted. With this view, he ordered the receivers of his revenue to remit a third of the customary impost to all Jews who should make a profession of Christianity. The principle of doing evil that good may come, has been reprobated by an inspired apostle; but Gregory's conduct was 
quite in keeping with the doctrine and practice of that apostate church of which he was at this time the head; which has always taught that the end sanctifies the means; in this, as in a multitude of other points, superseding the solemn declarations of God's blessed Word.

"Yet it would be unjust to suppose that more legitimate means of conversion were not used towards the Jews. Even amidst the gross superstition which was gradually overspreading Christendom, there were still many noble examples of genuine piety and zeal; and it cannot be doubted that, wherever these existed, there would be an earnest desire to bring over God's ancient people to the true faith by the appointed means of preaching and prayer. The doctrine, no doubt, had by this time become debased by superstitious additions, and the practice had been still more alarmingly perverted; but the grosser delusions of popery were yet unknown, and formality was not in the sixth century by any means substituted for heartfelt devotion. Among the bishops of the smaller sees, the inferior clergy, and the middle and lower classes of the laity, there unquestionably still remained many persons who held fast the essential truths of the Gospel, and evinced their right appreciation of them by lives of consistent godliness; thus, so far as in them lay, counteracting the evil effects too likely to flow from the secularity of the more wealthy ecclesiastics, and the irreligion of the nobles. We may surely hope that as, even in the darkest age of the church, the Lord Jesus still had his humble and holy 
followers, so their pious precepts and corresponding lives may have been from time to time blessed as the means of converting to the true faith some of the despised outcasts of Israel." *

The internal slave-trade of Europe, a cruel but lucrative traffic, had fallen almost entirely into the hands of the Jews. The desolating incursions of the barbarian hordes upon the Empire had almost depopulated the fair and prosperous provinces of their former inhabitants ; of whom though immense numbers were slain either in battle or in wanton massacre, yet a vast multitude were made captive and sold into slavery. The name of a slave-merchant is abhorrent to our feelings; but we cannot be surprised that the Jews should devote themselves to this branch of commerce with peculiar avidity. It was, doubtless, a very profitable speculation; for captives on the field of battle might be purchased of the conquerors, glutted with human life, for a mere trifle; while these, carried into distant provinces yet unscathed by war, where labour was valuable and money abundant, would be eagerly purchased at high prices. But even to the mind of a Jew the lust of pecuniary profit might be found an inferior stimulus to the thirst of revenge. He would recal the day when the Roman hand had fallen heavily on his captive fathers ; tradition would have treasured with painful accuracy the details of the dreadful desolations, and handed them down from generation to generation; and it would seem to the Jew of the sixth century as if he had personally witnessed those horrors. He would

$$
\text { * Huie's Hist. of the Jews, } 53 \text {. }
$$


think of the fettered and bleeding rows of captives exposed in the market-place of Gaza, or beneath the terebinth-tree of Hebron; of the gangs of slaves toiling under the whip in the mines of Egypt, or in the canal of the Isthmus; of the thousands slain in cold blood, or cast to the wild beasts, in the theatres of Cæsarea and of Berytus; of the chained herds dragged through the streets of Rome at the chariotwheels of the victorious Titus, when he celebrated his splendid but insulting triumph. We may imagine with what a keen satisfaction he would see the desolator desolated; trace the progress of the merciless hordes as they fell like locusts upon province after province of the fair empire; and hasten to the scene of ruin to feast his eyes upon the devastation. He would remember that it was the same Rome that now suffered, as then inflicted the miseries of war, and he would say in his heart, "As thou hast done, so is it done unto thee!" And while he would gloat over the general ruin, he might gratify a more private revenge by visiting upon the captives whom he had purchased, Romans and Christians, the afflictions of his nation.

The bitterness of this indignity, that Christians should be slaves to Jews, was not unfelt by the people; though it was difficult to prevent it. The practice itself was a mitigation of the horrors of war; for if the captives taken in battle could not have been sold, they would have been massacred in cold blood: the purchase-money offered the only incentive to the barbarians to spare the lives of their enemies. Hence the efforts of the Church and State 
were directed towards the amelioration of the condition of Christian slaves, and to their emancipation. Several of the emperors made laws to regulate the treatment of their bondmen by the Jews; and council after council laboured in the same work. The Councils of Orleans, about the middle of the sixth century [A.D. 540] decreed that if a slave was required to act in any manner inconsistent with the Christian religion, he might refuse; and might find an asylum from punishment in any church, the clergy of which were exhorted on no account to give him up, but to purchase his freedom from his master :that if such a slave should claim the protection of a private Christian, he should be bound to afford it, and purchase the redemption:-that a Jew who should by any means induce his slaves to profess Judaism should forfeit his property in their persons. About forty years later [582] we find the Council of Mâcon fixing the price at which a Christian slave might be demanded of a Jewish master at twelve shillings, and enacting that every Christian should have the right so to redeem. It has been justly remarked* that these laws calculated far beyond the character of the age, on the predominance of Christian charity over the love of lucre, both in the clergy and the laity. Indeed in the middle of the next century [655] we find the Council of Toledo complaining that even the clergy, in defiance of the law, sold captives to Jews and heathens. Gregory the Great earnestly sought to suppress the traffic, which he denounced as cruel and impious. He solemnly

* Milman, iii. 212. 
appealed to the kings of the Franks, Thierri and Theodebert, as well as to queen Brunehaut, entreating them to banish the slave-trade from their dominions, on the ground of their allegiance to Christ. In general he acknowledged the right of the Jewish slave-holder to the full price of his bondmen, which was to be paid out of the property of the church, but sometimes his indignation prevailed over his sense of justice. Thus, while he rebukes the bishop of Cagliari for delivering up some escaped slaves to their masters, he refuses to allow the "treasures of the poor" to be diminished on their behalf, but liberates the captives without any compensation.

In the Persian empire the Jews had suffered some vicissitudes of condition. In the fifth century a severe persecution had fallen upon them, which had lasted for seventy-three years. During this time the Sabbath was taken from them; that is, the observance of it was prohibited; the Synagogues were shut up, or given to the Magians; the principal Rabbis were thrown into prison, and some of them put to death ; and many of the nation, especially the young, apostatized from their religion.

Soon afterwards a famous Rabbi, named Meir, on the authority of a pretended vision, assembled four hundred men, and revolted against the Persian monarch. Unwonted success soon increased his forces, and for seven years this leader maintained the field against the armies of his sovereign. At length the reverse came; the Persians, having slain Rabbi Meir, took the city where the Prince of the Captivity resided; him they hanged, and they plun- 
dered the town. For thirty years afterwards the presence of the Jews was scarcely tolerated in the Persian dominions.

The accession of Chosroes the Great did not much ameliorate the condition of the Persian Jews; and the offer of those of Palestine to aid him with fifty thousand men, if he would besiege Jerusalem, though it affected his policy, did not engage his lenity towards them; for as he marched through Syria in his war with the Romans, he manifested his animosity against the Hebrews by shutting up all their academies ; thus extinguishing, as far as lay in his power, the light of science and learning.

Under Hormisdas III., they enjoyed toleration, and regained many of their privileges: but his son and successor Chosroes II. was a severe, though not an implacable foe to them. They had abetted the usurpation of the powerful and warlike Vahram, who for a time kept possession of the Persian throne; but Chosroes, having procured Roman aid, and obtained the mastery, executed a sanguinary vengeance upon his treacherous Hebrew subjects. Being firmly settled on the throne, however, this prince made it his policy to cultivate their friendship. To avenge the murder of the emperor Maurice, the Persian king made war upon the vile usurper Phocas, and invaded the Roman empire; the eastern provinces of which offered little resistance to his victorious arms. Syria and Judea were pillaged by his soldiery with remorseless rigour; and in these campaigns the Magian monarch disdained not to avail himself of the rancorous bigotry of the Hebrew race. The 
project of besieging Jerusalem, proposed to Chosroes the First, was reserved for his grandson to execute; and the Holy City once more sustained the horrors of a siege, a capture, and a pillage. A furious band of twenty-six thousand Jews in the conquering army enhanced the sufferings of the devoted city: they had gathered to the heathen standard, not from any sympathy with the Magian cause, but for the sake of imbruing their hands in the blood of those

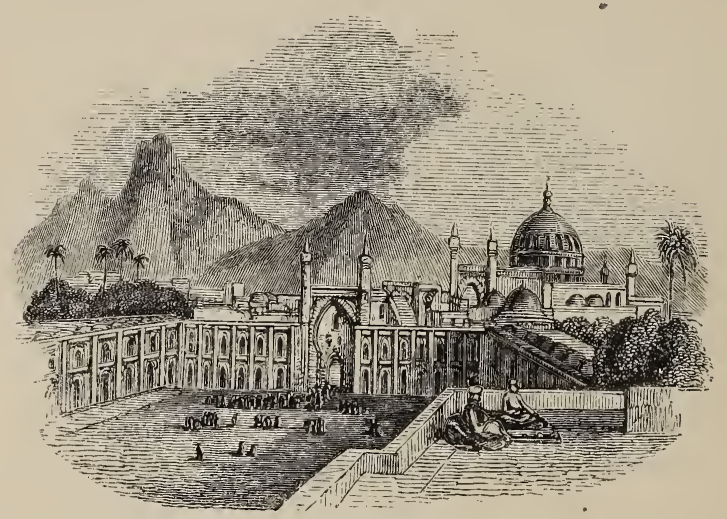

ISPAHAN.

whom they regarded, by the possession of Jerusalem, as their deadliest enemies. The churches of Gethsemane and Mount Olivet, of Calvary and of the Holy Sepulchre, and the Basilica of Constantine, were destroyed, together with the greater portion of the city: the costly vessels, robes, and other treasures, accumulated in the churches, the donations of three hundred years, were all taken, including a priceless treasure, the sacred vessels of the Jewish 
Temple, which, having been deposited in Rome by Titus, had been taken thence to Africa by Genseric. Belisarius had rescued them; and the emperor Justinian had restored them to Jerusalem. The after history of these venerable relics we are unable to trace; yet it would be interesting to know whether they were melted down by the undiscerning avarice of the Persian conquerors, or whether they yet remain to be discovered and identified in some of the mouldering vaults of Ecbatana or Ispahan.

The malice of the vindictive Jews was not to be satiated by the demolition of edifices, however sacred, nor the acquisition of spoils, however rich and venerable; they thirsted for Christian blood. And they were glutted with it ; for ninety thousand human victims of both sexes, and of ail ages and conditions, perished by their hands in the blood-stained streets of Jerusalem.

But short was the triumph of the strange alliance of the Gueber and the Jew. Within fifteen years the emperor Heraclius had rolled back the tide of war to the very centre of the Persian kingdom, and retaken the conquests of Chosroes. On the 14th of September, 629, the emperor, having laid aside the diadem and the purple, entered Jerusalem, bearing on his shoulder what was said to be the wood of the cross on which the Lord Jesus had suffered, which he deposited in the original sepulchre. His triumph was, unhappily, sullied by a vindictive massacre of the Jews, to which he was probably impelled by the discovery of a recent plot among that people, to exterminate the 
Christian inhabitants. "This had occurred at a time when the danger which threatened the capital had left Palestine unprotected; but however this new evidence of their relentless spirit of animosity against the Christians might have justified severe precautionary measures against the Jews, it could not palliate nor excuse the vindictive massacre or dispersion of the whole people; the guilt of which was enhanced by the additional crime of perjury, for which the fastings of the Greeks could ill atone." * With a far more defensible severity, Heraclius renewed the enactments of Adrian, which forbade any Jew from approaching within three miles of Jerusalem.

But, not satisfied with these severities in his own dominions, the emperor sought to stir up an odious persecution against the Jews in other and distant countries. In Spain, always pre-eminent for bigotry and intolerance, such counsels found a ready receiver in Sisebut, the Gothic king. The antiquity, the number, and the opulence of the Jews in that fertile peninsula have already been noticed; and the arrogant demand of the eastern emperor, to which the Spanish king insanely consented, was the immediate exile of these most valuable subjects. Baptism, or banishment, was the only alternative: ninety thousand are said to have accepted the former; a great multitude retired into France and the neighbouring countries; and many who found it impossible to remove, and were too conscientious to apostatize, suffered cruel tortures, imprisonment, and confiscation. 
The clergy, whom hitherto we have generally found advocating severe and intolerant measures, were at this time the friends of moderation. At a council soon after assembled at Toledo, presided over by the wise and pious Isidore, archbishop of Seville, the violent proceedings of Sisebut were condemned, and the principle solemnly adopted, That no one ought to be compelled to believe, since the Scripture saith, " $\mathrm{He}$ hath mercy on whom $\mathrm{He}$ will have mercy, and whom $\mathrm{He}$ will $\mathrm{He}$ hardeneth." * At the same time, with strange inconsistency, it was decreed that all who had been constrained to profess Christianity either by violence or necessity, should be obliged to maintain their profession, to avoid the scandal of apostacy.

Five years after these enactments another council sat at Toledo, called together by Suintila the Second. It was animated by a very different spirit from the former, for it praised the zeal, ardour, and faith of the new king, who was inflamed with a persecuting fury towards the Jews. This council solemnly ratified an edict which the king had enacted, for the banishment of all Jews out of his dominions. And in order more effectually to secure the perpetuity of the cruel ordinance, the council decreed that no future monarch should be allowed to ascend the throne until he had promised, by solemn oath, to maintain this law inviolate, denouncing the anathema of the Church on any king who should break it.

The misapplication of Scripture by which these severe measures were justified is sufficiently pal-

$$
\text { * Rom. ix. } 18 .
$$


pable. It was alleged, that since "the Kingdom of Heaven suffereth violence, and the violent take it by force," men ought to be hastened and constrained to obtain that blessing!

It has been observed that these decrees, if rigidly obeyed, would have saved the kings and councils all further trouble about the Jews in Spain. But it was impossible to enforce them literally; for

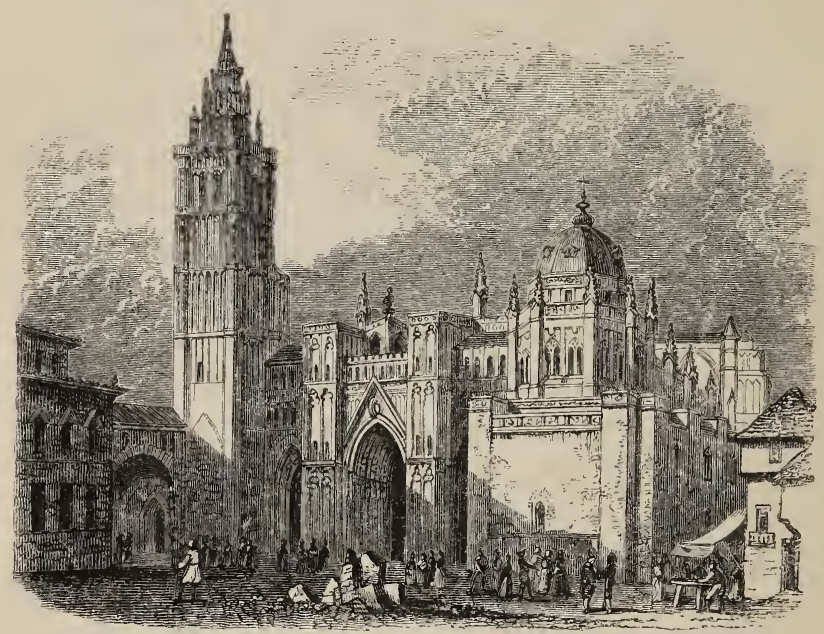

TOLENO.

the pertinacity with which this unhappy people clung to the soil which they had adopted as their own often prompted them to submit to privations and sufferings truly appalling. Hence we still find monarch after monarch, and council after council, labouring with more zeal than success in the same work. To enumerate all their edicts would far 
exceed our limits; but we cannot refrain from noticing the acts of one assembly, the pitiless severity of which has rendered it notorious. This was the twelfth Council of Toledo, which subjected every Jew to the punishment of a hundred lashes on his naked body, as well as confiscation of property and banishment; and this not merely for blaspheming the name of Christ, or refusing to celebrate the Lord's day and other festivals of the Church, but for observing any of the festivals of the Mosaic Law, or neglecting to bring any of their children or dependents to be baptized. The putting a difference between meats was equally penal; and it was deemed an indulgence of special mercy, that the eating of swine's flesh might be dispensed with in cases where long prejudice had produced a revulsion of nature against it. The circumcision of a child was to be punished on a man by mutilation, on a woman by the loss of her nose and the seizure of her property. Marriage was forbidden to be contracted, unless the parties promised in writing to profess Christianity; and all who were concerned in such a marriage, even the parents, were to be punished by scourging and fine. To read, or to allow to be read, books written against Christianity was punishable with a hundred stripes; on the repetition of the offence, the lashes were repeated with the addition of banishment and confiscation. No Jew was eligible to any office of command over Christians, not even to the humble situation of intendant, house-steward, or overseer. All slaves of Jews who professed Christianity were declared, ipso facto, free. A strict surveillance was ap- 
pointed over the proscribed race. On their Sabbaths and festivals they were all to appear in presence of the bishop: their wives and daughters were subjected to the authority of female superintendents appointed for the purpose; all Jews were constrained to eat, drink, and communicate with Christians ; they could not travel, even from town to town, without reporting their movements to the bishop, or judge, of each place, whose certificate of good behaviour was a necessary passport. To guard against apostacy from a profession in which there were so great temptations to be hypocritical, all converts from Judaism were required to bind their consciences by a prescribed form of oath, the sanctions of which were the most terrific that could be devised.

These sanguinary decrees were to be made public by the clergy, all of whom were commanded to communicate them to the Jews in their respective parishes.

But deliverance was at hand; for even now the victorious crescent of Mohammed had won its rapid dominion along the southern shores of the Mediterranean; and its armed hosts, swarming like locusts, had already cast a longing glance across the narrow straits that separated them from the fair cities and fertile fields of Spain. The jealous fears of their Christian persecutors already (perhaps not without reason) accused the Hebrews of intercourse with the advancing hosts; but madly strove to prevent it by severer measures, which had the inevitable result of effecting the correspondence which they deprecated. Numbers of Jews were driven away; but it 
was only to return in the train of the Moorish bands, to whom the information of these natives of the soil would be peculiarly valuable. But to trace the progress of the Saracen invasion requires a few years' retrogression.

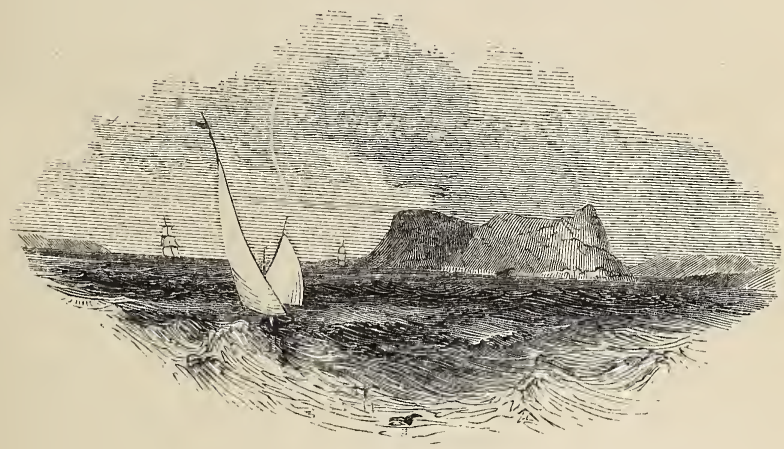

STRAITS OF GIBRALTAK. 


\section{CHAPTER XIV.}

\section{A REVIVING IN THE BONDAGE.}

\section{A. D. $629-1000$.}

And in the latter time of their kingdom, when the transgressors are come to the full, a king of fierce countenance, and understanding dark sentences, shall stand up. And his power shall be mighty, but not by his own power: and he shall destroy wonderfully, and shall prosper, and practise, and shall destroy the mighty and the holy people. Dan. viii. $23,24$.

In the same year that the emperor Heraclius had celebrated his lowly triumph in Jerusalem, an event occurred which was destined to have an important influence on the history of the world. This was the conquest of Mecca by the sword of Mohammed.

A populous colony of Jews had for several ages been settled in the fertile valleys of Arabia that open upon the shore of the Red Sea. Long before the Christian era many of the Hebrew race had found their way thither, probably crossing the narrow sea from the opposite shore of Upper Egypt, and Ethiopia. The desolation of Judea, under Titus, induced many more to join their adventurous brethren in the south, and, by fleeing across the desert, put a barrier between thentselves and the Roman power, which enabled them to defy the danger. In the peaceful security of this obscure 
but delightful region the Jewish strangers gradually grew sufficiently numerous to constitute an independent kingdom, known in history as that of the Homerites, governed by monarchs of their own religion. About a century before the period of which we write, the Jewish dynasty was overthrown by the victorious arms of an Abyssinian prince; and Dunaan, its last representative, was put to death. Henceforth the Jews no more rose to royal power; but they still retained a large share of numerical strength and political importance among the Arabian tribes, when Mohammed began to promulgate the lying doctrines of Islam.

For twelve years the self-called Prophet laboured to sow the seeds of his delusion in his native city of Mecca, with comparatively little success; and he might have still languished in obscurity, had not popular exasperation compelled him to flee to the neighbouring city of Medina; an event which marks the commencement of the Mohammedan era of the Hejira. The inhabitants of Medina espoused the cause of the impostor, and offered to sustain it by force of arms: thus the sword was unsheathed, which was to be bathed in Jewish and Christian blood, and whose destroying and devouring course was destined to run far and wide over Asia, Africa, and Europe. The Christian traces, with a sorrowing spirit, the desolating track of the fearful scourge over those fair provinces where first the gospel was preached and obeyed; and remembers that the once flourishing churches of Palestine, and Syria, and Asia Minor, of Greece, of Egypt, of North Africa, of 
Spain,-fell under the power of the Arabian crescent, from which very few have ever risen again. Must we not feel convinced that this punishment fell upon them by reason of their sin. History has drawn, in dark lines, the character of the Christianity (if the name be not a desecration, so applied) of that degenerate age ;-" The cause of true religion sank apace,-the gloomy reign of superstition extended itself in proportion to the decay of genuine godliness; and this lamentable decay was supplied by a multitude of rites and ceremonies."* "The austerities and ascetic habits of monks, the number of which became prodigiously increased; the senseless round of unauthorized and absurd will-worship, mortifications, penances, and rigorous fastings,-imposed a most oppressive and intolerable yoke, and superseded altogether the simplicity of gospel truth: while the most corrupt doctrines and legends concerning the figment of purgatory, the efficacy of good works, and human tradition, took the place of the written word of God." $\downarrow$

The early policy of Mohammed was to seduce both Jews and Christians to his standard by flatteries. Hence he acknowledged the divine mission of Moses and of Christ, exalting himself, however, above both:- -hence too, in his pretended revelation, the Korân, he incorporated a mongrel mixture of Jewish and Christian traditions. Some of the Jews for a moment were inclined to receive his pretensions, and to hail him as the expected Messiah. But the absurdity of such a supposition was too glaring; and 
accordingly they met with a stern refusal his invitations and blandishments. To the alternative, "The Korân or the sword!" they replied, "We are men of peace, we desire not war: but if you attack us, you shall find that we know how to defend ourselves with valour." Nor was this a vain boast; they fled to their fortified castles, of which many were in their possession, and bravely though unsuccessfully prepared for resistance. One by one the strong fortresses fell into the hands of the victorious Prophet, who treated the captives with great cruelty. The Kainoka, a Jewish community who resided at Medina, were the first to submit, after a gallant resistance; Mohammed commanded the whole body to be slaughtered in cold blood, and was with difficulty prevailed on, by the intercession of one of his most powerful followers, to spare their lives. The whole of their possessions were plundered, and they were driven, homeless and destitute, to seek a shelter on the Syrian frontier. The tribe of Nadhir, with a view to avert the storm, had designed to assassinate the Prophet at a banquet; their plot, however, only drew down upon themselves a more precipitate vengeance. After sustaining a siege they capitulated with honour, but with the confiscation of all their substance. Discomfited but not subdued, the Nadhir retreated to the Koreish, a pagan Arab tribe, the most powerful and the bitterest enemies of the new religion. These were already in arms, advancing against the impostor; after several engagements with doubtful success, in one of which Mohammed himself was severely wounded, he was at 
length besieged in the city of Medina by an Arab and Jewish army of ten thousand men. The besiegers, weakened by intestine jealousies and divided counsels, which were fomented by insidious spies, at length dispersed, leaving Mohammed at liberty to take vengeance on the Koraidha, another Jewish tribe, who had allied themselves with his enemies. For twenty-five days their fortress defied the besieger, at the expiration of which period they submitted to his discretion. The judgment was worthy of the cause. Their fate was left to the decision of the aged Abuamru, or Saad, who was " brought sick and wounded into the camp. 'O Abu-amru!' cried the Jews, ' have mercy upon us!' Saad uttered his judgment with awful solemnity,-' Let all the men be put to death, and the women and children be slaves.''A divine judgment,' exclaimed the fierce Prophet ' a judgment from the highest of the seven heavens!' Seven hundred Jews were dragged in chains to the market-place of Medina-graves were dug - the unhappy wretches descended into them-the sword did its office, and the earth was heaped over their remains. The inflexible Prophet looked on without emotion, and this horrible butchery is related with triumph in the Korân." *

The conquest of Chaibar, the chief seat of Jewish power in Arabia, followed. Eight fortresses in succession yielded to the invincible crescent, and left the town of Chaibar to the mercy of the victor. He allowed them to remain and cultivate their lands as his tenants, removable at discretion; a precarious

* Milman, iii. 252. 
toleration, which lasted, however, till the death of Mohammed, after which the Jews were exiled to Syria, the caliph Omar alleging the dying command of the Prophet, that none should be permitted to dwell on the soil of Arabia, but true Mussulmauns.

The conquest of Mecca speedily followed these victories; and it was not long before the whole of Arabia echoed with enthusiasm the watchword of the new faith, "There is no God but God; and Mohammed is his prophet." Henceforth the progress of the Moslem arms was like the progress of a whirlwind. In the reign of Abu-bekr, Syria and Mesopotamia were conquered; in that of Omar, Egypt fell; the provinces that bordered the southern shores of the Mediterranean were quickly added; and ere half a century had elapsed from the overthrow of paganism in Arabia, the empire of the crescent had touched the Atlantic. Here, as if appalled at the mighty waves of ocean, it stayed awhile, and even receded; but a few years sufficed it to gather up its strength and prepare for further extension. Turning to the left, the victorious Arabs (henceforth, by an identification with the tribes who had received their yoke, known to history by the name of Moors, ) looked over a narrow strait upon the rich cities and fertile fields of Spain; but the frowning promontory of Gibraltar,* the bulwark of the peninsula, might have bid them defiance, had not the vengeance of Count Julian, who had been deeply dishonoured by his ungrateful sovereign, king Roderick, been stronger than his patriotism. The indig-

* Jebel Tarik, the mountain of Tarik. 
nant governor betrayed the important fortress into the hands of Tarik, the Moorish general, whose name it still bears; and a Moslem army trod the soil of

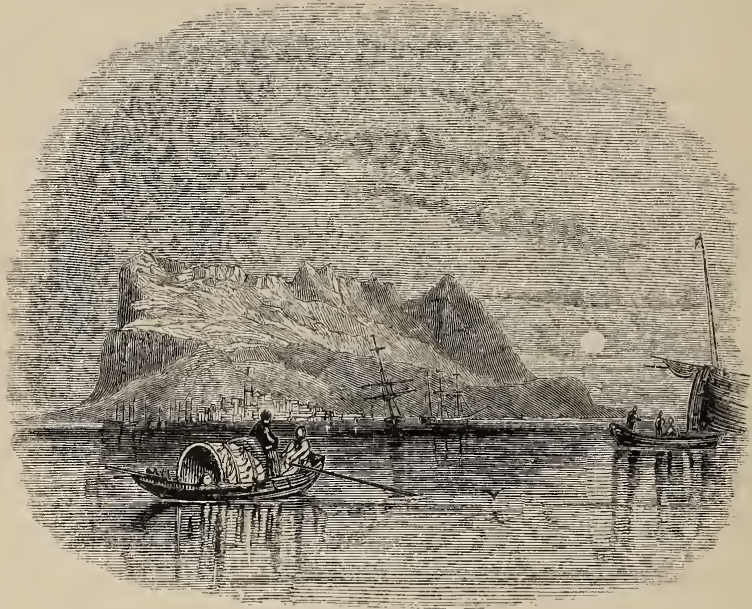

GIBRALTAR.

Europe. The overthrow of the Spanish king in the battle of Xerez de la Frontera, (July 19th, 711) put an end to the Gothic reign in Spain. Cordova, Granada, Jaen, Malaga, and Toledo, at that time the capital of the peninsula, either opened their gates to the victors, or offered an insignificant resistance; and before the African governor Musa ben Nosair, who was hastening onward at the head of large reinforcements, could cross the straits, his lieutenant Tarik was master of the noblest cities and fairest provinces of Spain. The arrival of Musa merely gave a fresh impetus to the tide of conquest, which, 
like a flood, overran the entire country, and to the universality of which the inaccessible peaks of the Asturian rocks scarce afforded an exception.

In the East, about the same time, Koteiba of Khorasan obtained possession of Mawaralnahr, Bokhara, and Turkistan; and Mohammed ben Kasem conquered the northern regions of India. Soleiman (715 to 717) overran the greater part of Asia Minor, and carried the crescent-standard to the trembling gates of Constantinople; while, in the reign of Omar ben Abd-el-Aziz, ere a century had expired since the solitary impostor was driven in disgrace from Mecca, the countries of Jorjan and Tabaristan were added to the Arabic dominion, which now touched with its crescent horns the cloud-capt summits of the Himalaya mountains on the one side, and the rolling billows of the Atlantic ocean on the other, and expanded from the Pyrenees on the north to the burning Sahara on the south.

Having thus briefly followed the lightning-like rapidity of Saracenic victory, we return to view some of the interjacent events more in detail. A history of Islamism is not our object; and hence we pass over the first assaults on the eastern empire, and pause only before the ever-sacred walls of Jerusalem. The Holy City was, it is true, at this time trodden by the Gentile foot; but its destinies are too inseparably linked with those of Israel, to permit any crisis in its existence to pass unnoticed by an historian of the Hebrew people, though they may have been far away in exile.

It was in the year $63 \%$, that Jerusalem once more 
saw before her gates the standards of a hostile army. Abu-Obeidah, the lieutenant of the caliph Omar, with an immense host, flushed with the conquest of Damascus and of Yermuk, sat down before the city, and sent in a summons to surrender. Its terms are sufficiently curious. "In the name of God merciful and gracious! from Abú-Obeidah-Ibn-Jirah to the Christians of the people of Ælia, health! and to all who follow the right way, and believe in God and in His Prophet! To come to the point. For my part, I beg you to bear witness that there is no God but God, and Mohammed is the Apostle of God, and that the moment of judgment will come beyond all doubt; and that God will raise men from the dead. And if you will stand to this, your blood is sacred unto us, as well as your property, and your children; and you shall be to us as brothers. But if you refuse, I will bring down upon you a people more earnest in their love of death than you in the drinking of wine, or eating of hog's flesh; nor will I ever pass away from you, please God, until I have killed your warriors, and made captive your children."

But the inhabitants of Jerusalem, and Sophronius their venerable patriarch, were deaf to these proposals, and resolved to defend their walls. Four months were wasted in the siege, during which the Arabs suffered severely by the sallies of the garrison, and by the inclemency of the winter. At length the patriarch demanded a parley, and promised to surrender, provided the caliph himself would visit the city in person to receive the capitulation. The 
"Commander of the Faithful" hesitated not to comply with the desires of his gallant foe; and with an outfit and equipage of true Bedouin simplicity, he marched from Medina to Jerusalem. He granted honourable and even liberal terms, which appear to have been faithfully kept. A tribute was imposed; but security of life and property was guaranteed; the churches, crosses, and monuments, were not to be destroyed, nor injured, nor despoiled; nor were Christians or Jews to be molested in the free exercise of their religion.

The summit of Mount Moriah, on which had stood the Holy Temple of God, had never been built upon since its desecration by Titus; and the spot which once had been inclosed by the Holy of Holies, had been converted into a dunghill by the monks, who, in a pitiful revenge, thus intended to insult the veneration with which the Jews regarded the sacred spot.

But Moslem tradition had invested this mountain with a sanctity no less deep than that which it possessed in the estimation of a Jew; and here the caliph Omar resolved to erect a mosque which should in some degree be worthy of the greatness of Arab dominion.*

The policy of the Mohammedan conquerors towards the Jews appears to have been comparatively mild and tolerant, and to have afforded them a relief from the persecution and contempt which

* The present magnificent mosque was built by one of Omar's successors, though it bears his name. The first structure is said to have been inferior to this in architectural pretension. 
they had hitherto commonly suffered. The edicts which had prohibited their approach to Jerusalem were no longer in force; they could reside there in

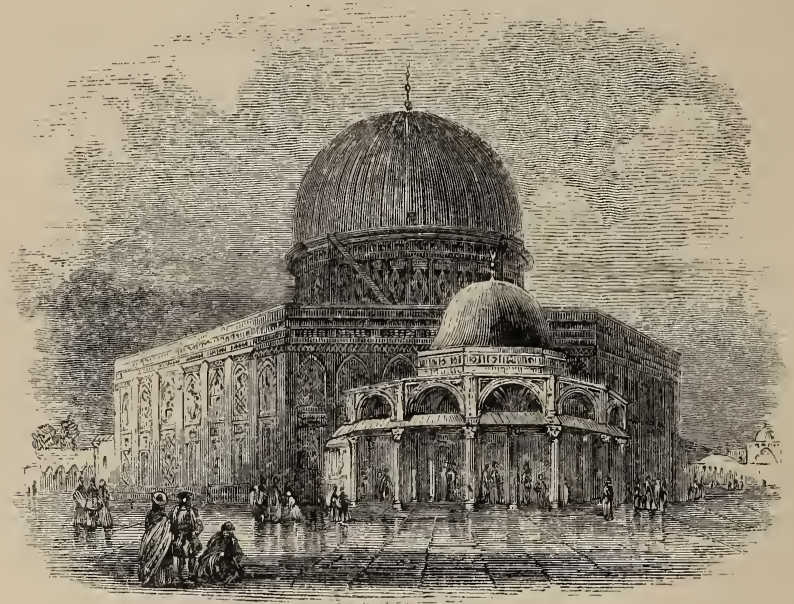

MOSQUE OF OMAR.

common with Gentiles, by paying a not exorbitant tribute to its present possessors. In Persia a bitter persecution of this people, by the grandson of Chosroes the Second, was arrested by the Saracenic conquests; and they were treated not only with moderation, but even with marked favour by the reigning caliph.

The dynasty of the caliphs of the house of Ommiyah was not unfriendly to the Jewish people, but they enjoyed a more marked prosperity under the Abbassides. Their academies in the east were in the greatest renown for learning, and were fre- 
quented by scholars from the extremities of Europe. To the court of Bagdad learned men resorted from all quarters, and were received with distinction, independent of their peculiar religious tenets; among them were always Jewish Rabbins eminent in erudition. The Prince of the Captivity maintained his state with a fuller splendour than ever, under the mild and beneficent sway of the enlightened Abbassides.

But it was in Spain, under the Moorish supremacy, that the Jews enjoyed the highest degree of liberty that has ever fallen to their lot since the dispersion of the nation, until we come down to our own times. And truly it was a reviving in the midst of their bondage, that, but for their being still exiles from their own land, might have made them well-nigh forget that they were still under the severe displeasure of Jehovah. It was the more remarkable, as well as the more delightful, because of the contrast with the treatment they had received in Spain under the Visigoths; which, as we have seen, was characterized by a pre-eminence in severity and intolerance. The dynasty of the Ommiyades was established in Spain by Abdel-rahman, who had escaped from the general massacre of the family at Damascus in 750, by the Abbassides. Being warmly welcomed by the Spanish Moors, he succeeded in overthrowing the Abbasside dominion, and made his triumphal entry into Cordova, at that time the metropolis of the country, which he beautified and enlarged; and where he built that magnificent mosque of a thousand columns, which is unrivalled 
in Moslem architecture. Under the Caliphate this city became the principal seat of learning in Europe, and the admiration of the world.

Amidst the general prosperity of this corner of Europe during the auspicious rule of the Caliphs, the Jews bore their full share. They became eminent for industry, talent, and opulence; and, with that love of study that has always dignified the Hebrew character whenever there has been opportunity for its prosecution, they took a leading place in literature and science. Theology, medicine, physics, astronomy, astrology, philology, and poetry were successfully cultivated by Jewish authors, whose works, translated into various languages, or lying in manuscript among the treasures of ancient libraries, are known and esteemed by the learned. Academies were established in the principal cities of the kingdom, especially Cordova, Toledo, and Granada, and the splendour of their reputation rivalled that of the Oriental colleges, whose light was now waning. Some of the most eminent of the eastern Doctors, indeed, fleeing from a persecution, to which the transient gleam of favour had given place, took refuge with their happier western brethren, bringing with them as well their authority as their lore. Of one of these Babylonian Rabbins a curious anecdote is told, illustrative of his eminent learning. Having been taken captive by pirates, he was sold in a Spanish port as a slave, together with his son. Being redeemed, from a motive of charity, by some Jews of Cordova, without any knowledge of his name or character, Rabbi Moses resorted to the 
School, covered only with a coarse sack, for want of better clothing [96\%]. The questions under discussion drew forth the stranger, who proceeded to argue the most intricate points of theology with a profundity and an eloquence that astonished and charmed all the auditors. "Henceforth," said the presiding Rabbi, "I resign my office; I am content to become the humble disciple of yon slave in sackcloth; let him be your Doctor!" The proposal was carried unanimously; and to Rabbi Moses was intrusted the honour of presiding over the first seat of learning in the world; an office which, after years of undiminished reputation, he yielded successively to his son Rabbi Enoch, and his grandson Rabbi Nathan. Of the last of these it is stated,-and the anecdote is curious, as showing the state assumed by the Jewish Doctors of the middle ages, as well as their reputation,- - that in his daily journeys to and from the city, and in his occasional excursions around Cordova, he was followed by his admiring disciples in immense numbers, clad in sumptuous oriental apparel; and that sometimes seven hundred chariots swelled the lengthening procession.

This state of prosperity and consideration seems to have continued with few exceptions, during the time of the Moslem dominion in the peninsula, extending nearly to its final extinction in the kingdom of Granada. When the nation was divided into a number of petty sovereignties, in the middle of the eleventh century, we find a Jewish Rabbi filling the responsible and honourable post of secretary of state to the King of Granada, who also conferred on him the dignity of 
Prince of the Jewish people. During the administration of this minister, not only were many privileges secured to his people in Spain, but those in

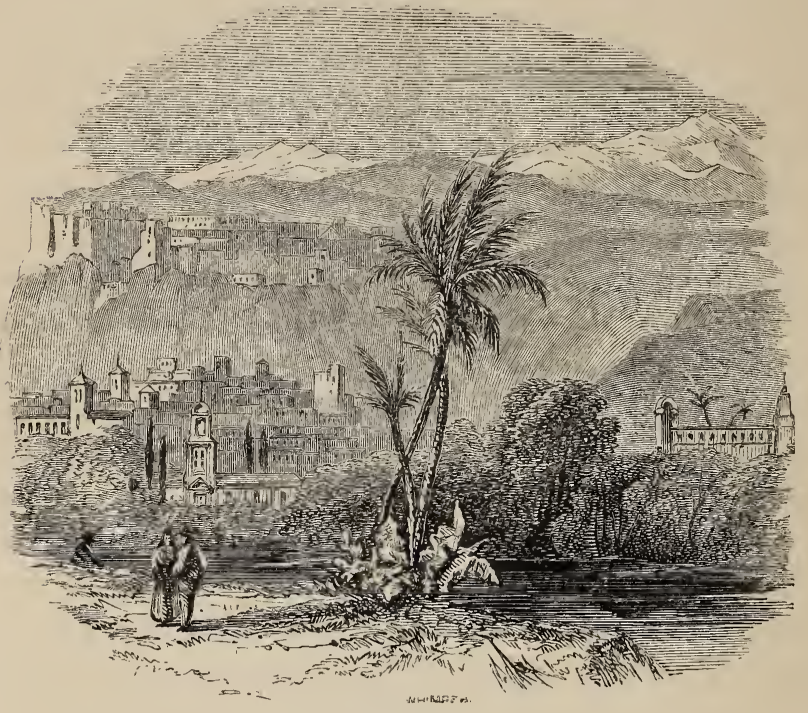

GRANADA.

foreign countries experienced his protection and bounty. The African, Egyptian, and Babylonian Doctors were his pensioners, who had the satisfaction of seeing their benefactor's authority and office inherited by his son. But even here the Jews were to be reminded of the precarious tenure by which they held the favour of the Gentiles; for on a Rabbi's presuming to attempt the conversion of the Moslems to Judaism, the King of Granada took umbrage, threw the zealous teacher into prison, and after- 
wards hanged him, and commenced a severe persecution of the Hebrew race. Fifteen hundred families underwent great sufferings before the storm was allayed; which happily did not extend into the neighbouring states. [1064.]

The privileges enjoyed by the Jews of Spain under the illustrious Alphonso VI. of Castile, provoked the envy of the Church. He too had granted equality of civil rights to all his subjects, whence it frequently happened that Jews were found filling offices of trust and authority, and sometimes even presiding at the tribunals of justice. [1080]. Pope Gregory VII. approved not this toleration, which he denounced as an oppression of the Church, an exaltation of the synagogue of Satan, and an affront to Christ. The Spanish king, however, engaged in rescuing the kingdom from its Moorish invaders, and often hardly pressed by them, was too wise to listen to such reproof, or to persecute that numerous and wealthy class, whose subsidies he found so indispensable for the prosecution of his wars. A similarly moderate policy was pursued by his grandson Peter I., in spite of similarly intolerant counsels. [1096.]

As the Christian sovereigns gradually recovered the kingdom out of the Moorish grasp, the security and prosperity of the Jews waned in proportion, and prepared the way for those dreadful reverses which we shall soon have to narrate. Yet the long period of which we speak, extending over five or six centuries, was so signal a lightening of the Jewish bondage, that it has been aptly called the Golden Age of Judaism ; of which one of their own historians 
has given the character in these forcible terms; "That he who has not heard of the glory, the splendour, and the prosperity in which the Jews lived in Spain, is ignorant of what is most notorious." *

In the contiguous kingdom of France, during the same period, the Jews enjoyed a consideration but little inferior to that of their Spanish brethren. If they were less eminerst for literature and science, it was probably because these pursuits were less congenial to the unsettled and semi-barbarous state of the French nation, than to the polished and luxurious habits introduced into the peninsula by the Orientals. But the learning of the age and country was largely the possession of the Jews: the medical profession was principally in their hands; they were the bankers and financiers of the day; and the prevalence of education among them fitted them for offices of trust, both of a public and private nature, when learning was so scarce that kings, barons, and even bishops, were not invariably able to read and write. "To the flourishing commerce of the Israelites, the extended dominions of Charlemagne opened a wide field ; from the ports of Marseilles and Narbonne their vessels kept up a constant communication with the East: in Narbonne they were so flourishing, that, of the two prefects or mayors of the city, one was always a Jew; and the most regular and stately part of the city of Lyons was the Jewish quarter." $\phi$

A prohibition issued by Charlemagne shows the wealth and the power of the Jews in his dominions.

* Sol. Ben Virg. p. 8. + Milman, iii. 280. 
They had ostentatiously boasted that the sacred vessels of gold and silver, the vestments and other treasures of the churches and cathedrals, the convents and abbeys, frequently came into their hands; pledged by the needy and unscrupulous clergy, for money which they devoted to their pleasures. The scandal came to the ears of the monarch, who finding on inquiry, that the boast was far from groundless, severely reprimanded the sacrilegious clergy, and prohibited the pawn or sale of church property on severe penalties. With the Jews, however, he interfered not in the matter, as they were manifestly not the parties to blame in such a commerce.

The favour with which the Jews were regarded by the potent and illustrious monarch of the West, is shown by the selection of an individual of that nation, to fill the responsible office of ambassador to his rival in glory and magnificence, Haroun al Raschid, the renowned caliph of the East. Though associated with two Christian nobles when he set out on his distant mission, the death of his two companions in the course of the journey, left Isaac the Jew to sustain alone the dignities as well as the burdens of the embassy. The objects of the correspondence of Charlemagne with the court of Bagdad are not known, if indeed it originated in any other motive than personal vanity, or the natural desire of the two most illustrious monarchs in the world to exchange courtesies. The Hebrew legate returned to his master with many valuable presents; and as he was appointed to conduct a second embassy, we may safely conclude that his zeal and 
ability were pleasing to both courts. [A. D. $797-$ 800.]

In the reign of Louis the Debonnaire, the Jews maintained their privileges inviolate. His physician, Zedekiah, was of the Hebrew race, who enjoyed the reputation of a sorcerer so potent that the Egyptian magicians were but bunglers to him. So high was the favour with which the Jews were regarded at the French court, that the nobles and even princes of the blood were fain to solicit their good offices with rich presents of dresses to the Hebrew ladies. This monarch issued many edicts confirming and enlarging their privileges; granted several charters of special indulgence; exempted them from certain

- taxes; altered the public market-day, because, being held on Saturday, it interfered with the celebration of the Jewish Sabbath; encouraged the erection of new synagogues : and in every respect conferred upon them the rights of citizenship. Nor could all the efforts of Agobard, the powerful bishop of Lyons, whose jealousy was excited by these privileges, avail to the curtailing of them.

In Italy, Greece, and other parts of the world we know scarcely anything of the condition of the Jewish people, at this time. The silence of history may be considered a testimony favourable to them; as, if they were allowed to be quiet, we may be sure they were prosperous. Their general intelligence and ability, their education, their industry and application, and their love of commerce, insured them comfort and even opulence; and the only evil which they needed to dread was, the hatred of the nations 
among whom they were scattered. This for a while slumbered; and with a singular uniformity the nations, both of the East and of the West, as we have seen, seemed to have forgotten the old grudge against the Jew, and to treat him as a fellow man. It was "a little reviving in their bondage;"* a lull in the storm; a bright gleam of sunshine through the thick clouds; a mitigation of their woe, which occurring just midway in the long tribulation, served to break its intensity, and by reminding them of mercy, to sustain the broken and exiled people in the darkness of the night, which was already gathering, and was about to fall upon them more deeply than ever.

For in those days shall be affliction, such as was not from the beginning of the creation which God created unto this time, neither shall be. And except that the Lord had shortened those days, no flesh should be saved : but for the elect's sake, whom he hath chosen, he hath shortened the days. Mark xiii. 19, 20.

* Ezra, ix, 8. 


\section{CHAPTER XV.}

\section{PERSECUTIONS.}

\section{A. D. $1090-1500$.}

WE have already briefly alluded to the persecution which succeeded to the prosperity of the Jews under the munificent Caliphs of the East. The Emirs, or commanders, about the middle of the tenth century, succeeded in reducing the powers of the caliphate to a mere shadow, depriving the nominal rulers of their title at pleasure, while they themselves exercised a despotic authority. The favour of the Caliphs was perhaps a sufficient motive for the enmity of the Emirs towards the Jews. But the Hebrew chroniclers assert that the state and splendour of the Princes of the Captivity had long excited the envy of the Babylonish lords, who felt or feigned a fear lest some ambitious Jew should at length wrest the government from the hands of the Moslems. The Sultan Grela le Doulat resolved to extirpate them; and having put to death the Prince of the Captivity with his family, instituted a bloody persecution against the Jews, the result of which was, that the academies, so long the seats of learning, were shut up, the doctors proscribed, and the students driven into exile; while the body of the 
nation resident in the East, was reduced to a mere handful of men, an immense number being either slain, compelled to flee into Arabia, Spain, or France, or perhaps dispersed through the unknown regions of central and farther Asia. This sad dispersion occurred towards the end of the tenth century.

But these misfortunes were light compared with those which soon after fell upon this unhappy people; for the Crusades were now approaching, those singular wars of fanaticism in which the military power of the West was brought into fierce collision with that of the East, when the cross of Christ was used as a sanction for all the horrors of war, massacre, rapine, and pillage, and the slaughter, in cold blood, of thousands of unoffending men, women, and children, was esteemed an act so highly meritorious, as to entitle the perpetrator to heaven.

The conquest of Jerusalem by the Arabs had not prevented the access of Christian strangers to it for the purposes of pilgrimage. As the darkness of Papal apostacy grew more and more obscure, the substitution of vain and meaningless observances for faith in the blood and righteousness of the Lord Jesus Christ as the means of a sinner's justification, became more and more absolute; and among these works of man's devising, the performance of pilgrimages to the scenes of the Lord's passion took a prominent place. During the dynasties of the Caliphs, no opposition seems to have been made to the visits of pilgrims to the Church of the Sepulchre, though the tribute imposed on them for the privi- 
lege may have been occasionally increased by the rapacity, or exacted with circumstances of needless tyranny by the cruelty or bigotry of the local governors. Among the most valued of the presents which Isaac the Jew bore to his master from the Caliph Haroun, was the key of the Sepulchre, a delicate courtesy, intimating that the chivalrous Moslem renounced his right to the dominion of that "sacred and salutary place" in favour of his imperial ally. Nor did the accession of the Fatemites materially affect the comfort of the pilgrims, if we except the dreadful scenes enacted by the insane monster Hakem, which were but temporary.

The power of the Caliphs, however, was fleeting away before the rapid advance of the Turkish hordes, which burst upon western Asia like a flood. City after city, and province after province, fell under their impetuous assaults, until at length their jurisdiction extended from the deserts of Tartary to the Indian Ocean, and from the Bosphorus to the Red Sea. The conquest of Palestine put them in possession of Jerusalem [A.D. 1076], and the difference between the indulgence of the Saracens and the brutal insolence of the Turkish barbarians, was severely felt by the pilgrims. The number of these visitors had become immense. To use the words of the historian, "the zeal of pilgrimage prevailed beyond the example of former times, and the roads were covered with multitudes of either sex, and of every rank, who professed their contempt of life so soon as they should have kissed the tomb of their Redeemer. Princes and prelates abandoned the care 
of their dominions, and the numbers of these pious caravans were a prelude to the armies which marched in the ensuing age under the banner of the cross." *

These wanderers, when, after innumerable dangers and toils, they at length arrived at the sacred spot which was the object of their ardent, though misdirected, veneration, had to encounter a host of merciless savages, whose rude contempt of the foreigners was mingled with the most furious zeal for Islam. Insult and oppression, rapine and pillage, were the lot of those who, worn with privation and toil, and often wasted with disease and famine, needed the sympathies of friends and the comforts of home. The performance of public worship in the churches of Jerusalem was often interrupted by the violent intrusion and outrage of the Turkish soldiery, and the clergy were treated with the most cruel indignities.

Such was the state of affairs when Peter, the hermit of Amiens, arrived at the Holy City on pilgrimage [1094]. His sympathies were strongly excited by the sufferings of the Christian population, both native and strangers, and his indignation aroused by the barbarities of their merciless oppressors. He found that no pilgrim could be admitted into the city, except upon the payment of a gold coin, equal in value to a guinea of our money, a sum which not one in a thousand of the impoverished and way-worn travellers could pay; and thus the price of their admission, as well as their sub-

* Gibbon, Decl. and Fall, 1vii. 18. 
sequent maintenance, became an intolerable tax upon the charity of their more opulent brethren.

The hermit's indignation was greatly inflamed by these oppressions, and he at once conceived the design of arousing Europe to a common revenge. $\mathrm{He}$ determined to travel through Christendom, preaching a crusade for the wresting of Jerusalem from the infidels; and having presented himself to the Pope, Urban the Second, who encouraged his design, he at once set out on his mission. He passed through Italy and France, preaching to countless thousands; and, as he painted in strong terms, with sighs, and tears, and ejaculations, the woes of the Eastern Christians and the pilgrims, his rude eloquence inspired the people as with one heart to engage in the insane enterprise. Nor was the Pope idle on the occasion: at the Council of Clermont he proclaimed a plenary indulgence, or the remission of all sins (such are the blasphemous pretensions of the Papacy), to those who should engage in the expedition, which was dignified with the name and symbol of the cross. At the united voice of the Pontiff and the preacher, the populace arose by myriads; prince and peasant, noble and serf, mailed knight and smutty artisan, old and young, rich and poor, men and women, joined in the overwhelming enthusiasm, and clamoured to be led at once against the infidels. In Germany, another fanatic, named Godeschal, followed the example of Peter, and collected a large army of the very dregs of the people, who wandered, a rude undisciplined horde, from town to town, accumulating 
as they went along. An idea may be formed of their intelligence from the fact, that their leaders were a goose and a goat, which the credulous mob believed to be inspired, and whose devious and uncertain footsteps they followed with the implicit trust of those who had infallible guides.

But the misguided zeal of the licentious mobs found enemies nearer home than Jerusalem. Some self-elected leader informed them that they were going abroad to exterminate the infidels, while they were leaving behind them the descendants of those who had crucified the Son of God. Would it not be a worthy commencement of so noble an enterprise to put to death the wicked Jews, the enemies of God and man, and thus purge Christendom from such awful wickedness? The suggestion was received as if it had come from heaven; and to massacre the unoffending Jews, or to convert them at the point of the sword, was at once embraced as a service eminently acceptable to God. There were other motives besides religious zeal. Long subsisting animosity and mutual hatred rankled on both sides. Charges of usury and extortion added to the odium in which the Jews were held. They were the unsparing creditors of a multitude of needy debtors. They were numerous and wealthy, and the greedy mob longed to lay hands upon the endless treasures which they were reputed to possess. As the rude multitude passed along the banks of the German rivers, where the Jews were most numerous and opulent, they inundated the streets with the blood of this unhappy people. At 
Cologne, Mentz, Worms, Spires, and Trèves, many thousands were massacred, and the historian affirms that a more sanguinary stroke had not fallen upon their nation since the days of Adrian. Fourteen hundred were burned to death at Mentz, and in the indiscriminate tumults that ensued, half of that flourishing city was reduced to ashes. At Cologne, two hundred who had plunged into the river to escape a more bloody death, were rescued from it only to be hewn in pieces on its banks. At Worms they appealed in their agony to the bishop, but he coldly replied, that there was but one alternative, baptism or the sword. Many, in the desperation of fear, submitted to the ceremony, which they abjured as soon as the form was over. Others chose rather to die by their own hands. At Trèves the Jewish women seeing the crusaders approach, took knives and plunged them into the hearts of their children, saying, that it were better to give them a painful passage into Abraham's bosom, than to abandon them to the Christians. When they had so done, they tied stones around their own bodies, and leaped from the bridge, to save their honour at the expense of their lives. At Spires alone did they meet with any mercy. The bishop of that city afforded to the poor hunted Hebrews his powerful protection; but so rare was the exercise of humanity at that period, that the bishop's conduct seemed to his contemporaries wholly inexplicable, except upon the supposition that he had received an immense bribe. The annalists of $\mathrm{Ba}-$ varia reckon twelve thousand Jews who perished in 
that country, while the number of those who fell in Germany is said to have been incredible. One cannot wonder at the retribution of God, that this immense horde of robbers and murderers should themselves fall an easy prey before their martial foes. Three hundred thousand passed into the Grecian empire, pillaging and murdering as they went; but long before they reached the frontiers of Palestine, the whole were cut off, either by the arrows of the martial Hungarians, or by the scymitars of the Turkish cavalry [1096].

The fate of this numerous, but straggling and undisciplined, host of forerunners, did not prevent a number twice as great from following in their track. But these constituted a well-disciplined and ably commanded army. A hundred thousand fighting men, armed with helmet and coat of mail, and mounted on horseback, mustered in the plains of Bithynia, under the command of the most renowned princes, nobles, and knights of Europe, the very flower of chivalry; and these are said to have been accompanied by a host of six hundred thousand men able to bear arms, without reckoning the priests and the monks, the women and the children, that thronged the Latin camp.

The details of that mighty shock, when the strength of Europe was poured upon the fields of Asia, it is not our province to narrate; a varied success brought the remnant of this immense host before the walls of Jerusalem in the middle of the last year of the eleventh century [June 7th, 1099].

Once more the Holy City sustained the horrors of 
a siege, and the still worse horrors of an assault. Forty days the Moslems gallantly defended their possession, at the end of which the Europeans carried the wall, and poured like furious demons through the streets. Carnage, violation, and pillage were the ceaseless occupation of sixty thousand men for three days. The marble platform that covered the summit of Mount Moriah, where once had stood the Temple, where now stood the Mosque of Omar, was deluged ankle-deep with human blood, on which floated, as on a tide, the mangled limbs and bodies of ten thousand men. Seventy thousand Moslems were slain before the vengeance of these (so called!) Christians was glutted, and the infection of the corpses beneath a July sun, caused an epidemic pestilence. The number of the Jews in the city is not known, but their fate is recorded,-they were burned in their synagogues. Thus terminated the First Crusade.

A repetition of the terrible scenes of massacre and pillage was enacted about half a century afterwards, on the preaching of the Second Crusade. Rudolph, a fanatical monk, travelled through central Europe, stirring up the populace to take vengeance on all unbelievers. The inhabitants of Germany enthusiastically responded to his fiery harangues. At the watchword of "Hep! hep!" * a cry which long afterwards carried terror to the heart of every Jew that heard it, they rushed to the grateful task of slaughter, and torrents of Jewish

* A word supposed to have been formed of the initials of the words Hierosolyma Est Perdita, Jerusalem is destroyed. 
blood again deluged the fair cities of the Rhine. [1144.] Mentz, Worms, Cologne, Spires, and Strasburg, again enjoyed the odious pre-eminence in murder and rapine. Bernard, the good abbot of Clairvaux, the great promoter of the enterprise, reprobated the intolerance of these crusaders, and even repaired in person to Rudolph, to restrain his intemperate zeal. His personal character gave a weight to his representations, which was of great advantage to the proscribed race. Peter of Cluni, styled the Venerable, also opposed the murder of the Jews, though, by a strange morality, he argued the propriety of robbing them of their goods, and strongly recommended this profitable compromise to Louis the Seventh of France; but that monarch appears to have been too politic to listen to the advice.

His son, Philip Augustus, was less lenient. The Jews in France had long been numerous, and the general practice of usury had accumulated in their hands a large portion of the property of the kingdom. With the exception of the Lombard moneylenders, the Jews were the only persons in Europe from whom cash could be obtained. All classes of persons were indebted to them. The jewels of courtiers, the title-deeds of nobles, the vestments and ornaments of the bishops, found their way into Jewish coffers; and in spite of edict after edict to the contrary, the clergy continued to pawn the church plate into the same sacrilegious hands. They scrupled not to exact extortionate interest, and to use all the means in their power to demand the 
"pound of flesh" from the Gentile debtor, "according to the bond." The nation was loud in its complaints of their extortions; and public fame repeated numberless tales of horror, of atrocities perpetrated in secret by the odious Jews; tales which had their origin in the detestation in which they were held. The ill success of the crusades was attributed to their magic arts. They were accused of compassing the death of all the swine in a province, by means of sorcery; of decoying Christian children into their houses, in order to crucify them; and of obtaining possession, by means of bribery, of the consecrated host, which they stabbed with knives, and subjected to indescribable indignities. At Pontoise, it was asserted that they had crucified a young man named Richard, whose body had afterwards performed many miracles. The bruit of this affair reached the ears of the king, who hastened to the place, and seizing the resident Jews to the number of eighty, condemned them, without any form of trial, to be burned alive. The complaints of extortion he met by an edict annulling all debts due to Jewish creditors, and commanding the surrender, without any payment, of all pledged property that remained in their hands. Among the revelations of this confiscation, the people were horrified to behold a golden crucifix, and a gospel emblazoned with precious gems, in the hands of the infidel brokers. Soon after, the synagogues were simultaneously surrounded by troops on the Sabbath-day, and the inmates dragged to prison, while their houses were seized and rifled. But these acts 
were but the prelude to still more tyrannical measures. New laws were promulgated, ordering the Jews throughout the kingdom instantly to dispose of their moveable property, and to quit the dominion, leaving their lands and houses forfeited to the crown. Property sold under such circumstances of course realized but little; the populace rejoiced in the anguish and distress of those whom they had been accustomed to consider oppressors and unbelievers; and the poor exiles were compelled to wander from the land of their birth, with their wives and children, almost in a state of destitution, not knowing whither to go, or where they might find rest for their foot [1181].

In the south of France, it is true, the cruel edict was not enforced with the same rigid severity as in other parts, and there many Jews continued to reside under the protection of the powerful barons. These would afford their exiled brethren some assistance, and perhaps facilitate their clandestine return; for, towards the end of this century, we trace them again becoming numerous in various parts of the kingdom where they had been proscribed, and filling many streets of Paris, by the tacit consent, if not with the direct approval of the monarch. The love of wealth was a sufficient inducement to tempt them again to settle among their avowed enemies. Towards the latter part of this king's reign [1223], the Jews were again recognized by law, and decrees were passed to regulate that pecuniary traffic, which both borrower and lender found too convenient to be suppressed. They were interdicted from lending 
to an artisan, or to any one who was possessed of no inheritable property; to any monk or clergyman, without the permission of his superior; or to any burgher, villain, or trader, except on the authority of his lord. Once more ecclesiastical treasures, plate, \&c., were absolutely precluded from pledge, as well as the cattle and implements of agriculture. To prevent extortionate usury, the rate of legal interest was fixed at two deniers per livre per week, a rate, however, which would nearly equal the enormous amount of 50 per cent. per annum. This enactment was evaded by the borrower giving his engagement to pay the prescribed rate of interest on a larger principal than he had actually received; and thus an amendment of the statute was required, by which the terms were made more strict. The king himself found it profitable to permit this commerce, as he derived no inconsiderable revenue from the tax imposed on these brokers for the privilege of carrying on their lucrative, though still odious, traffic within his dominions.

To this line of business, indeed, they appear to have been almost shut up by popular antipathies. The goods in which they dealt were disliked for the simple reason that they came from the hands of Jews; and the most absurd prejudices were cherished with respect to them: if they sold milk, the people fancied that it was not the milk of cows, but that of their own wives, which they vended; if they were butchers, Jewish beef and mutton were discovered to have a disagreeable taste, or they reserved the best meat for their own people, and sold only 
offal to the Gentiles; if they attempted the culture of the vine, their wine was unfit to be drunk, and the clergy, moreover, scrupled to use Jewish wine at the table of the Lord.

We have not yet alluded to the presence and lot of the Jewish people in England. Before the Norman Conquest, we find little more than traces of their existence here, and they appear to have for the most part lived among the Saxons in peace and security. But in the middle of the eighth century, the doctrine that it was well-pleasing to the Lord Jesus to revenge his death upon the posterity of His murderers, was energetically promulgated by Egbricht, the archbishop of York. "His mind depicted them as beings whose very presence was contaminating; and to prevent their evil influence over persons of his communion, he forbad all Gentiles within his province to appear at Hebrew festivals, or to hold any social intercourse with that despised race. The extensive injury which his archiepiscopal bull effected, was more permanently detrimental to liberty in England, than all the thundering anathemas of Rome; for the Northumbrian clergy, to their already useless and unmeaning theological controversies, now added the fiercest intolerance against a few thousand unoffending citizens, who were not accused, even by Egbricht, of any particular crime. The publication of this decree made the subject popular, as the inhibition was promulgated in the most rural districts, whose inhabitants, perhaps, had never seen a Jew." *

* Mitchell's 'Records,' 544. 
After this, the condition of the Hebrew race in this country seems to have become increasingly unfavourable; the intolerance of Popery, which had now obtained a firm footing here, would doubtless show itself in ebullitions against them, similar to those we have traced upon the Continent. Yet this is rather matter of probable conjecture than of certain knowledge. The Saxon kings were less acrimonious than the Romish clergy; and it was doubtless for protection against the violence of fanatical zeal, or popular antipathy, that Edward the Confessor declared the persons and property of the Jews in his dominions to be appendages of the crown.

By the laws of Alfred, of Ethelred, and of Canute, whoever should deny Jesus Christ, or should teach or preach against the Gospel, or renounce the New Testament, were punished with death. Yet it would seem that these edicts were not peculiarly directed against the Jews ; and, as history is silent respecting any execution of the sanguine decrees, we may infer that their numbers were small, and their condition inconsiderable. Indeed, most of our early historians assert that there were none of this people in England before the time of William the Conqueror. It was reckoned an additional grievance, which that prince imposed upon his Saxon subjects, that he brought Jews with him from Rouen, and gave them protection in England.* Yet it is probable that no good-will to that unhappy people, nor any principles of enlightened policy influenced William, but that, as has been suggested, " he intended to use them to

* Hollingshed, iii. 15. 
his own advantage, dealing with them as sponges to suck up the English treasure, which he might then squeeze out into his own coffers." William Rufus favoured them, in order to annoy the ecclesiastics, with whom his irreligious pleasure-loving character had little sympathy: he even encouraged a public disputation, at London, between the bishops and the Jews, profanely swearing "by St. Luke's face,"* that if the latter were victorious in the controversy, he would himself turn Jew. The contest was probably carried on with more zeal and acrimony than legitimate argument on both sides; but, presuming on the king's countenance, the Jews became insolent, and drew upon themselves the fury of the populace. They were compelled to fly for safety into the country, where yet they were not secure. Two hundred are said to have renounced their faith in one day, at Dunstable, to avoid death; for all pilgrims, and as many as had entered into the Order of the Holy Cross, were by their oaths bound to spare none of the enemies of Christ, and killed the Jews wherever they found them.

The odium in which this unhappy people was held was ever and anon exasperated by horrible reports, which we have seen revived even in our own days. It was said that the Jews were in the habit of kidnapping a Christian child at the season of the Passover; that after having tortured him with knives and needles, they crucified him with indignities, in contemptuous allusion to that dreadful act of their forefathers, at which the sun had

* Or, "by the Face at Lucca." 
hid his face. In the reign of Stephen [1145] they are reported to have crucified a child at Norwich, and another at Gloucester in that of Henry II. [1160]. In 1230, two Jews, named Ralph and Samuel, professed to make a discovery of as many as eighteen children, who, at different times had been stolen from their parents and put to death; and similar statements were made on many other occasions. It is probable that some of these accusations were not unfounded; for, by a singular constitution of the human mind, the suggestion of a crime, to which otherwise there might be little temptation, sometimes creates a morbid desire for its perpetration. Some of those who were executed for the alleged murders, confessed their guilt, to the great horror of the public, and to the confusion of the Jews.

It would have been little if the sword of public justice had alone avenged such crimes, real or supposed; but these wild tales created a popular hatred and dread of the alien race, which was continually breaking out in tumults and massacres, when Jewish blood flowed like water.

Nor were other imputations wanting; crimes utterly improbable, and even absurd, were charged against them, which show that a Hebrew was regarded as an incarnation of diabolical malice and wickedness. Unscrupulous extortion, and grinding usury, we may readily believe to have marked their dealings with their Gentile neighbours; but, that they should poison the wells, in order to destroy, by wholesale, the people on whose need they lived, or 
that they should lay trains of wildfire to burn the city of London, where they enjoyed royal protection and peculiar privileges, could obtain credence only when men's reason was, as it were, overlaid by an enormous fanaticism. Yet these reports were greedily swallowed, and stimulated the lawless mob to acts of horrid atrocity. The poor Jews were hunted like wild beasts, their houses torn down and pillaged; their wives and daughters abused, and themselves murdered without mercy.

The whirlwind of popular fury reached its height at the commencement of the reign of Richard Cœur de Lion. His father had, in some sort, extended his protection over his proscribed subjects, at least so far as to grant them certain indulgences, and to reserve to himself the privilege of draining them of their wealth. The coronation of Richard was intended to be a pageant of unwonted pomp and splendour, and multitudes crowded to London to witness the spectacle. The Jews prepared to come also, to testify their allegiance to their young monarch, and to grace the dazzling show by the display of their opulence. But the fear and hatred with which they were popularly looked upon, caused an edict to be issued, strictly prohibiting the presence of one of the abhorred race, at the august ceremony. The discovery of some unfortunate Hebrews, whose curiosity overcoming their discretion, had impelled them to enter with the crowd, kindled a furious persecution. The intruders were dragged out of Westminster Abbey, and half-killed with the staves of the constables; but the report spreading through the 
city, the populace rose in wild tumult, and beset the houses of the Jews. These were supposed to contain great wealth, masked under a sordid and mean exterior ; nor did the reality belie the expectation. Treasures of gold and silver coin, plate, jewels, costly spices, the rarest precious stones and pearls, gorgeous raiment,-were found in rich profusion, and became the prey of the greedy and excited mob. But darker passions than the lust of gain animated the raging multitude; superstition, terror, revenge, thirst for blood, were fiercely prevalent, the flame of the incendiary's torch devoured more than could be carried away, and rapine and massacre raged unchecked. Through the whole of the night the work of havoc went on, nor was the arm of the civil power sufficiently strong to restrain the furious passions of the mob, until the next day, when, weary with pillage and slaughter, they began to retire.

A feeble attempt was made to assert the majesty of the law; some of the rioters were apprehended, and three of the ringleaders suffered capital punishment. But the grounds of their execution show, in a manner not to be mistaken, how little even the law itself regarded the life and property of the Jew. Two of the three were punished for robbing a Christian, pretending that they mistook him for a Jew ; the third for having burnt down a Christian's house in the flames which he had kindled in that of his Hebrew neighbour! Such was the feeling with which the whole transaction was regarded, not only by the brutal and licentious mob, but by the learned 
and religious, that a contemporary historian, writing from his cloister, gravely ascribes to God's mercy that $\mathrm{HE}_{\mathrm{E}}$ had so signally delivered the infidels into the hands of His faithful people!

The example of London was followed with fatal promptitude in other parts of the country. If mercy or justice pleaded in the hearts of the people, these were overpowered by the fiery zeal of multitudes of itinerant friars and monks, who were eagerly preaching a new crusade. At Norwich, already distinguished for its hatred to the Jewish race, a fierce massacre took place; at Stamford, and at Bury St. Edmonds, similar sanguinary scenes were enacted; through the winter of this horrible year, 1189-90, Jewish blood was made to flow in many places, until at length it reached a terrible crisis at York. At the time of the outrage in London, a Jew of York, who happened to be in the metropolis, consented to purchase his life by submitting to baptism. At the subsequent judicial proceedings, he appealed to the king and was permitted to recant, after which he shortly died from the effects of the ill treatment he had received. When it became known at York that he had apostatized, a mob assembled before his house, murdered. his wife and children, and pillaged his property. The Hebrew inhabitants, well knowing what they had to expect from an infuriate mob who had tasted Jewish blood and spoil, fled with their moveable treasures to the castle.

The governor was at this time in the city, and the persecuted Jews having reason to suspect his good 
faith, boldly resolved to maintain the castle for themselves alone. The governor, finding the gates of his own citadel closed against him, applied to the sheriff for aid, who was then in the town with an armed band. The sheriff's consent was readily obtained; but when he saw the savage fury of the excited mob, and heard their wild cries for the lifeblood of every Jew in the city, he would fain have recalled his fatal command. It was now, however, too late, the troops were animated with the same furious zeal as the populace, and were already rushing to the siege.

The Popish clergy were, as usual, foremost in the work of intolerance: they scrupled not to go in their vestments, at the head of the crowd, exhorting them to take unpitying vengeance. One dignitary in particular, a canon regular, distinguished himself above all; he stood in the midst of the multitude, clothed in his surplice, continually urging the assault with vehement shouts, "Destroy the enemies of Christ! destroy the enemies of Christ!" Day after day found this furious priest at his selfelected post, with unabated zeal directing the attack, until at length a huge stone, shot from the battlements, struck him, and ended his career.

For many days the besieged bade defiance to their infuriated persecutors, but at length it became manifest that resistance was hopeless. A council of the principal persons was called to deliberate on their course. No mercy was to be expected from the bloodthirsty mob without, whose fury had been rather inflamed than allayed by the prolonged 
resistance. Every eye was turned to the Rabbi, a venerable man, and eminent for his knowledge of the Law. His decision was stern. "Let us first slay our wives and our babes, and then ourselves, rather than fall into the hands of the uncircumcised!" The majority of the assembly approved the saying; and those who shrank from such a course were allowed the liberty of departing. The dreadful alternative was adopted: having speedily collected into a heap the treasures they had preserved, they set them on fire, and buried such as could not be thus destroyed. Each man then plunged the sword into the bosoms of his family, and each then slew his neighbour; the Rabbi having seen the last of his friends perish, fell upon his own sword.

The next morning the besiegers beheld the flames issuing from every part of the fortress, and the few wretched individuals, whose timidity had shrunk from the suicide, wringing their hands upon the ramparts, begging for mercy. It was promised them on condition of instant submission to baptism. The gates were opened, and the mob rushed in, but as regardless of the obligation of their promise as they had been of the dictates of mercy, they put every individual who survived, to the sword. Five hundred Jews, or, as some say, fifteen hundred, perished on this dreadful occasion.

Disappointed of their prey, as well as of the spoil they had hoped to obtain, the populace rushed to the cathedral, where the contracts and bonds were preserved in the archives. All records of debts due 
to Jewish bond-holders were collected, and cast into an immense fire.

By law, all debts owing to Jews became at their decease the dues of the crown; the burning of these bonds, therefore, while it released the debtors from their obligations, released them at the expense of the royal exchequer. To murder a few hundred Jews might have been passed over, but to deprive the king of so large an amount of property was unpardonable. Richard therefore instituted a rigorous investigation; Rydal, the chancellor, was sent down with full powers; the governor and sheriff were deprived of their commissions; the principal citizens entered into recognizances for the peace of the town; but as the ringleaders, and those most compromised in the atrocious affair had fled across the Scottish border, the blood of the slaughtered Hebrews remained unavenged.

How often, amidst these times of trouble, when their hearts sank within them, as they looked round and saw no rest for the sole of their foot, when every sanctuary seemed shut, and every heart steeled against them, must the poor exiled Jews have thought of the solemn denunciations of their holy law, in which Jehovah had written as "with a pen of iron and with the point of a diamond," * both the sin of Judah, and its consequent punishment!

And I will scatter you among the heathen, and will draw out a sword after you; and your land shall be desolate, and your cities waste. Then 
shall the land enjoy her Sabbaths, as long as it lieth desolate, and ye be in your enemies' land; even then shall the land rest, and enjoy her Sabbaths. As long as it lieth desolate it shall rest; because it did not rest in your Sabbaths, when ye dwelt upon it. And upon them that are left alive of you I will send a faintness into their hearts in the lands of their enemies; and the sound of a shaken leaf shall chase them; and they shall flee, as fleeing from a sword; and they shall fall when none pursueth. And they shall fall one upon another, as it were before a sword, when none pursueth : and ye shall have no power to stand before your enemies. And ye shall perish among the heathen, and the land of your enemies shall eat you up. And they that are left of you shall pine away in their iniquity in your enemies' lands; and also in the iniquities of their fathers shall they pine away with them. Lev. xxvi. 33-39.

And ye shall be left few in number, whereas ye.were as the stars of heaven for multitude; because thou wouldst not obey the voice of the Lond thy God. And it shall come to pass, that, as the Lond rejoiced over you to do your good, and to multiply you ; so the LORD will rejoice over you to destroy you, and to bring you to nought; and ye shall be plucked from off the land whither thou goest to possess it. And the LORD shall scatter thee among all people, from the one end of the earth even unto the other; and there thou shalt serve other gods, which neither thou nor thy fathers have known, even wood and stone. And among these nations shalt thou find no ease, neither shall the sole of thy foot have rest: but the LORD shall give thee there a trembling heart, and failing of eyes, and sorrow of mind : And thy life shall hang in doubt before thee; and thou shalt fear day and night, and shalt have none assurance of thy life: In the morning thou shalt say, Would God it were even! and at even thou shalt say, Would God it were morning ! for the fear of thine heart wherewith thou shalt fear, and for the sight of thine eyes which thou shalt see. Deut. xxviii. $62-67$.

Besides the outbreaks of popular violence to which the Jews were ever liable, they were constantly subjected to enormous confiscations and extortions by the reigning monarch, whenever his exchequer needed replenishing. The explanation of the favour shown them by William the Conqueror, already suggested, is doubtless applicable to his 
successors, who knew too well the value of such a mine of wealth, not to encourage its increase in their realm, whenever they dared to defy the prejudices and antipathies of their subjects. Henry II., who granted them some privileges (such as that of having a burying place in most of the principal towns, besides London, to which alone they could hitherto resort), extorted from them the sum of 5000 marks; and just before his death, when preparations were being made for a crusade, the Jews were taxed at $60,000 \mathrm{l}$., while the demand from all the rest of his subjects amounted to only $10,000 \mathrm{l}$. more. The death of the monarch, however, prevented the levying of this tax.

The vile and worthless John at first affected great lenity to the Jewish race, encouraging, by several favourable edicts, their immigration into his dominions. But when the immunities thus secured to them had induced many to settle in England, and in confidence in the royal faith to begin to acquire wealth, suddenly, without any excuse, he commenced a course of the most enormous injustice. In the year 1210, he declared the property of all Jews to be forfeited to the crown; and every individual of the Hebrew race in his dominions he commanded to be imprisoned, without regard to age, sex, or condition, in order that by cruel tortures he might wring from them the discovery of their concealed treasures. A flagrant instance of oppression has obtained notoriety, as well from its ingenious cruelty, as from the pertinacity of the victim. A wealthy Jew of Bristol was seized and 
thrown into prison, where 10,000 marks were demanded of him. He pleaded inability to pay so vast a sum, but was told that the king was inexorable, and that one of his teeth should be drawn every day until he produced the cash. Seven teeth in succession were taken from him; at length his resolution gave way, and he regained his liberty and saved his remaining teeth by the payment of the required tax. Sixty thousand marks were wrung: from the Hebrew race by this wicked procedure; the success of which emboldened the unprincipled monarch to repeat it at a later period of his reign.

In the contests between John and the powerful barons, the Jews again suffered great hardships. The king had declared the latter to be his own property, on which pretence the hostile barons made no scruple of plundering them, particularly in London. When the city was threatened with a siege by the monarch, the houses of the Jews were pulled down to afford materials for the fortification of the walls, and their treasures were confiscated to replenish the military chest.

But these arbitrary and oppressive extortions were more freely resorted to by Henry III. than by any of his predecessors. Some of his first acts, indeed, wore an aspect of lenity; the Jews were released from prison, and placed under the protection of certain officers appointed for the purpose. They were declared amenable only to the crown, and to the civil tribunals; and when the intolerant Archbishop of Canterbury fulminated the decrees of the church against them, prohibiting all Christians from 
supplying them even with the common necessaries of life, the king interposed his authority, and annulled the cruel anathema.

The tide of royal favour, however, soon began to ebb, and during the long reign of this prince, the Jews often suffered for his improvidence and prodigality. A serious and not improbable charge, that of clipping the coin of the realm, was made the occasion or the excuse for an exorbitant tax. Every Jew was commanded to pay to the royal exchequer one-third of all his personal property. This edict was passed in 1230; in 1232, a second fine of 18,000 marks was imposed upon them, and in 1236, a third, of 10,000 .

These sums appear to have been independent of other large amounts extorted from private individuals. The daughter of Hamon, a Jew of Hereford, purchased an exemption from taxes with 5000 marks ; and Aaron, of York, compounded in the same manner at the rate of 100 marks per annum. Yet this same man solemnly assured Matthew Paris, the eminent historian, that in seven years the king had wrung from him 30,000 marks of silver, besides 200 marks of gold, paid as a kind of tribute to the queen.

To enumerate the various demands for money made by this monarch during his protracted reign, would be but to repeat, with trifling variations of times, sums, and circumstances, what we have already adduced. Ground down to poverty by the frequency of the extortions, the Jews at length solemnly protested that they could pay no more, 
and threatened to leave the country in a body. As a last resource the king actually sold to his brother Richard all the Jews in his realm for the sum of 5000 marks.

Earl Richard seems to have treated his newly acquired vassals with leniency; but on his election to be king of the Romans, the king probably reasserted his claim; for we find him again selling them to Prince Edward, by whom they were made over to some merchants of France.

Meanwhile the public mind was harrowed by a revival of the old charge of crucifying a Christian child. The hero of this ridiculous story, "the sweet Sir Hugh of Lincoln," figures in several of our old ballads, as well as in Chaucer's Prioress's Tale. The facts were established by the sort of proof then considered sufficient in a court of justice. The child, having been kidnapped, had been fattened for ten days, and then crucified in an assembly of deputies from all the Jews in the country. The body was buried, but, strange to tell, the earth would not conceal the dead, but cast out the remains, which were then thrown into a well. Here it was found, and being carried to the cathedral was canonized as that of a saint and a martyr, and buried with great pomp; the claim to the former character being founded on the fact that the child had been accustomed to sing hymns in the choir in honour of the Virgin Mary! The fable was profitable, for crowds of pilgrims came from all parts of England to present their offerings at the shrine of the infant martyr. As for the Jews accused of this 
crime, a great number of them were found guilty, and suffered the punishment of death.

The last years of Henry's reign were marked by increasing cruelty towards the poor Jews. One and another privilege was taken from them, and more frequent and more grinding acts of extortion were perpetrated; and almost the final edict of his life was one of oppressive injustice. By this law, the Jews were prohibited from holding any lands or even houses, except such as were then in their possession. All their lands and manors were actually confiscated, and those which they held by mortgage were decreed to revert to their Christian owners, without any interest being allowed upon the bonds. Finally, all arrears of debt were ordered to be instantly paid, on penalty of imprisonment. The general distress produced by these tyrannical edicts, particularly the last, is reported to have moved the commiseration of the bitterest enemies of the Jews, the friars, and their rivals in usury, the Caorsini, or foreign bankers.

Edward I. pursued the same stern policy as his father had done. Various oppressive acts were passed, but none bore more heavily on the unhappy Jews than the actual prohibition of that branch of commerce to which they were indebted for their wealth. Usury was absolutely forbidden, and all debts were declared to be cancelled on the payment of the principal.

It was intended by these statutes to direct the attention of the English Jews to manual labour, to agriculture, and to ordinary branches of trade and 
merchandise; but the habits of a people are not to be changed by an act of parliament. The genius of the alien race was not adapted for these occupations, or the golden streams that flowed from them, oozed too slowly to compensate the oppressions and hardships of exile. The clipping and debasing of the coin of the realm presented, under such circumstances, temptations too strong to be resisted, and many Jews were accused of replenishing their diminished coffers by these unlawful acts. The law fell upon them with rigour; convictions and executions succeeded each other with frightful rapidity, of which some idea may be formed from the fact, that in London alone, in a single year, two hundred and eighty Jews suffered the penalty of death for this crime.

At length popular odium could no longer tolerate the presence of the abhorred race; the public clamours grew louder and louder, till the king dared no longer resist the voice of the people, insane as it was. An edict was passed banishing every Jew from the kingdom. It was in the year 1290, that this inhospitable decree was issued, which once more sent out upon the hostile world, homeless and penniless, many thousands of peaceful industrious citizens, the majority of whom were guiltless of any crime of which man could justly take cognizance. Whither could the poor exiles turn for shelter? The civilized world seemed to cast them out; everywhere branded as the enemies of mankind, they were driven from one inhospitable shore to another equally barbarous, meeting every- 
where detestation, disgust, or contempt. But the decree was peremptory; money just sufficient to enable them to reach the nearest foreign strand was allowed them, but the whole of their property besides was forfeited. The words of the statute, it is true, enjoined that the exiles should be treated with kindness until they took their departure; but these injunctions were little regarded. Every mark of popular scorn and insult was heaped upon them, as they travelled with heavy hearts to the coasts; nor was any opportunity neglected of overreaching them, and even of robbing them of the scanty pittance they were permitted to retain for their expenses. The conduct of the ship-master of Queenborough was probably but a sample of the morality displayed on the occasion. This villain having engaged to transport a considerable number of the exiles to France, had already received their baggage on board, and taken the passage money; but sailed away, leaving many of them on shore at the mouth of the river. To their cries and prayers that he would take them on board, he heartlessly replied by an infidel taunt. He enjoined them to call on Moses, who having once divided the Red Sea for their fathers, might perhaps perform a similar feat for them. It is satisfactory to know that this wicked man was afterwards punished for his villany.

The lowest computation estimates the number of Jews who were thus sent into exile at 15,000 ; and the sufferings of this great number of persons, deprived of their property, and cast loose upon the world, may be reckoned among the heaviest blows 
inflicted on the nation since the dispersion. Not the least affliction was the loss of their libraries, as well those which were private as those which were attached to the synagogues, many of which were very rich in Hebrew literature: these were seized by the monasteries, especially the celebrated ones at Oxford and Stamford.

Thus was Great Britain freed from the hated presence of the Israelitish nation; nor for nearly four centuries afterwards durst a Jew set his foot on English ground, except at the peril of his life.

To record at length the condition of the Hebrew people at this period through each of the countries of Europe, would be to present an almost unvaried repetition of similar scenes. We are accustomed to speak of these as "the dark ages," and dark indeed was their aspect to the miserable Jew. Popular massacres, legal executions, royal confiscations, and decrees of banishment, succeeded each other with dreadful frequency. In France, during the reign of Louis IX., the Inquisition exercised its horrid cruelty against those called Heretics, among whom the Jews took the foremost place. The intolerant bigotry of the monarch encouraged these proceedings : nor were they displeasing to the people. On the old charge of crucifying a child at the Passover, a furious mob rose at Paris, and slew many Jews; the example spread into the provinces, and more than two thousand five hundred were murdered. To such a height did these sanguinary tumults proceed, that the Pope felt compelled to interpose his authority. 
The zeal of this Pontiff, Gregory IX., manifested itself rather against the literature, than against the persons of the Israelites. He denounced the Talmud as a fountain of impiety and sorcery, and commanded all the copies of it to be committed to the fire. Louis IX. zealously concurred with the Pope in the execution of his decree, and twenty-four cart-loads of the mysterious volumes were burned in Paris. Many of the Rabbins escaped into other countries, carrying their precious books, but leaving their property to confis cation. By Philip the Fair, in 1306, the whole race were again banished from France; and the miseries they then endured were so great that this banishment is reckoned as one of the four cardinal afflictions which have befallen the nation. The Jewish chronicles affirm that the numbers which at this time were expelled from France were twice as great as those which forsook Egypt with Moses; but this statement displays the extravagance of romance, rather than the sobriety of history.

Probably, however, many found means to elude the strictness of the law, and to remain in the country; or else crept back again to the scenes they had left: for five years had not passed when another decree insisted upon their total expulsion. Yet, strange to tell, three years after, we find Louis X. negotiating with the exiles about the privilege of returning, which they were willing to purchase at a large price. The services of the alien race as money-lenders were so valuable, and the condition of the public finances so impoverished 
without their aid, that the King declared in his ordinance for their recall, that he yielded only to the general desire of his people. Their synagogues, cemeteries, and sacred books were restored to them, and they were permitted to claim one-third of all debts, which had been cancelled by their banishment. The other two-thirds the King appropriated to his own exchequer.

Brief was the prosperity which the people of Israel thus enjoyed. The severities of the Inquisition, and the outbreaks of popular hatred still pursued them. The crusade of the Shepherds in 1320, was signalized by terrible atrocities committed upon the proscribed race. In the reign of Louis IX. an immense horde of undisciplined peasants had traversed the country, pillaging and murdering, until they were at length dispersed with much slaughter by the forces of the nobles. The Jews suffered much in that insurrection, but far more in that which we have now to relate. In the reign of Philip the Long, a still greater multitude assembled, in the south of France, or as some say, in the north of Spain. Three hundred thousand men, headed by a deposed priest and a renegade monk, began their desultory march, with no very precise object, except a persuasion that in some way or other the Holy Land would be recovered by them. They ravaged Navarre, massacring in particular all the Jews that fell into their hands; in the single city of Estella, 6000 Jews are recorded to have been slain by them. Thence they turned eastward to Languedoc; where they com- 
mitted like ravages. Nothing could resist the progress of the unwieldy multitude, who overran the provinces like a swarm of locusts. The Jews were still the especial objects of their vengeance; to rid the world of the unbelievers, and to possess themselves of their great wealth, were motives which appealed to the fanaticism and the cupidity of these self-elected soldiers of the cross.

A large number of Jews having taken refuge in the fortress of Verdun, endeavoured to stand a siege. The shepherds encompassed the plain, and at length set fire to the gates of the castle; the besieged, finding the defence hopeless, threw their infants down from the battlements to move the pity of their assailants. But pity found no place in their hearts; they still pressed on, and at length obtained an entrance, but found only a garrison of corpses; the unhappy Hebrews had turned their swords against each other to avoid the insult and tortures of their implacable persecutors.

The torrent poured on, but space would fail to describe the massacres and other horrors perpetrated at Bordeaux, at Agen, at Castel-Sarasin, at Narbonne. The French monarch at length took the field against his insurgent subjects, and drove them back to Navarre and Arragon. Atrocities continued to attend their retreat, similar to those which had marked their advance, but the King of Arragon mustering an army against them, slew their leader, and dispersed the band.

As if in all calamities the dispersed and broken people of Israel were destined to have the pre-emi- 
nence, the pestilence, that so frequently scourged the crimes of Europe during the middle ages, fell most heavily upon them. An absurd surmise was uttered, and everywhere greedily repeated, that the rivers and wells were poisoned, and that the Jews were the wicked authors of the calamity. It was in vain that they pointed to their own sick and dead, to prove that the disease fell as heavily on them as on the Gentiles. Popular clamour and credulity were above argument and proof; the lepers, of whom there were many, confessed that the wealthy Jews had hired them to contaminate the water. Great numbers were burned without the trouble of legal formalities; though experiment might easily have shown the impotency of the means alleged to have been used. The ingredients of the terrific mixtures confessed to by the tortured lepers were such as the following: human blood, urine, three sorts of herbs, and a consecrated wafer, dried and put into a bag; -or, the nails and hair of a hanged felon, with the blood of a toad, made into a bolus !

The punishment inflicted on the wretches thus condemned by the verdict of the mob, was the horrible one of being burned alive. At a place called Chinon, near Tours, a large hole was dug, which was filled with fire, and twenty-eight (or as some say a hundred and sixty) Jews of both sexes were promiscuously flung into it. Some waited not for the hands of their tormentors, but plunged boldly in with songs of exultation; and mothers cast their infants into the glowing pit, to save them from the infliction of baptism. At another place 
forty persons, who were kept in prison till the means of burning them could be got ready, determined to disappoint their persecutors by anticipating death. The most venerable man amongst them they selected to perform the sad office for the rest, to which he consented on condition of being allowed one of his more vigorous companions to assist him. When all the rest were slain, the youth slew his aged companion, but then endeavoured to escape. He was, however, caught and burned to death.

The same scenes occur again and again in this most lamentable history; so that the reader is continually tempted to suppose that the incidents which he peruses have been by some mistake repeated by the historian. Thus about the middle of this century (1348), the pestilence again sweeps the land, the Jews are again accused of poisoning the fountains, and again are massacred by hundreds.

At length hatred and fear prevailed over every dictate of policy; a decree of banishment was passed by Charles VI. which was never revoked for a period of four hundred years. In the year 1394, this King, who in the earlier part of his reign had extended a measure of protection over his Hebrew subjects, was unable longer to resist the incessant exhortations of the Papal clergy, and the louder clamours of the populace. He passed the fatal decree; a month was allowed them to wind up their affairs, after which France no more afforded the wandering people of Israel the shelter of a home until they reached the times in which we live. 
Up to this period the Jews in the Peninsula had not entirely lost that consideration and prosperity which, as we have seen, they had enjoyed under the Moorish dominion. The tide of conquest had been for some time turned, and the Kings of Castile and Aragon had gradually driven the Mohammedans from the northern and central parts of the Peninsula, and confined them to the Kingdom of Granada [1248]. The Jews appear to have been treated by most of the Castilian and Aragonese monarchs with kindness; they held offices of responsibility, such as those of ministers of finance, and counsellors of state; and the royal physician was commonly one of the Hebrew race. Learning also flourished among them, and they appear to have been preserved by the free access which they enjoyed to the higher walks of literature and science, from that exclusive devotion to money-getting, to which they were so generally shut up in other countries, and from the universal practice of extortion which had affixed so terrible an odium to their brethren. Foreign commerce was successfully cultivated by the Spanish Jews, particularly in the sea-ports of Aragon, which afforded them many facilities for lucrative trade with Italy and the East. Yet in the kingdom of Aragon, the condition of this people was less uniformly prosperous than in that of Castile. The opulent commercial city of Barcelona, the rival of Genoa and Venice, was very jealous of admitting aliens to a share of its prosperity, or to a participation in its municipal honours.

The favour which the Jews enjoyed under the R 5 
protection of the Spanish monarchs met with opposition rather than concurrence from the Cortes, the nobles, and the clergy. The two former were animated by political and pecuniary motives; their estates were encumbered with mortgages, and the situations of trust, whose profits might have replenished their finances, were in the hands of the opulent strangers; while these strangers were enemies to the church, and blasphemers of religion. Thus, in the minds of the bigoted and ambitious clergy, the flame of religious intolerance was added to the other powerful incentives to jealousy. And these feelings occasionally broke out into open violence, in spite of the royal protection. The Bishop of Toledo, in the beginning of the thirteenth century [1209], vexed to see the prosperity of the Jews in his diocese, stirred up a persecution against them. At the head of a mob, whom his exhortations had excited, he proceeded to the Synagogue, which he dispersed, and then began to plunder the houses of the unbelievers. Similar violent proceedings disgraced the clergy of Seville, and other cities, the object being to induce the Hebrews to renounce the profession of the Jewish religion, and to submit to baptism. Immense numbers chose to purchase immunity from persecution, at the price of their conscience; and the potency of the persuasion employed on these occasions, is avouched by no less than 200,000 of insincere conversions.

But more commendable efforts were made for the removal of the veil, which hid the glories of Christi- 
anity from the Jewish mind. Among the most remarkable of the incidents connected with the Jews of Spain, were the public disputations which were held from time to time between the Papal clergy and the Rabbins. A very celebrated conference was that held at Barcelona, in the presence of James I., King of Aragon, in 1263. The disputants were Father Paul Christiani, and Rabbi Moses, both esteemed to be able theologians by their respective partizans. The nobility and people crowded from all parts of the kingdom to this discussion, which was so keenly maintained, that neither would yield the palm of victory to his opponent.

A few years afterwards the same champion of Christianity entered the lists with another Rabbi, but with no better success. The king, however, had recourse to another sort of logic: for, at the earnest exhortation of the Pope, he banished the Jewish Rabbi from the kingdom, and commissioned Father Paul to visit other cities to dispute with the Jews. Orders were also issued to bring the sacred books used by the Jews to Barcelona, to be examined by the monks, who were empowered to tear out any passages that were blasphemous or hostile to the Christian faith.

Still more celebrated was the disputation held at Tortosa, in 1413, before the Antipope, Benedict XIII., who still retained the title and authority of a true Pope in the kingdom of Aragon. The Christian advocate on this occasion was a Jewish convert, who had no doubt that he could convince the Rabbins, out of their own Talmud, that Jesus 
was Christ. The result of the conference is variously narrated: the Spanish writers state that all the Rabbins, save two, yielded the contest and received baptism; but the Jewish chroniclers maintain that their doctors came off with honour, and were only admonished against excessive usury. They own, however, that they found it necessary to bribe many bishops who were present, to persuade the Pope to put an end to the discussion.

Whatever appearance of fairness the conduct of * Benedict may present, he was no enemy to violence and persecution; for this solemn conference was followed by a bull, in which he levels the most tyrannical enactments at the professors of Judaism. Every copy of the Talmud, or of any commentary on it, was ordered to be given up; they were prohibited from reading any work that opposed Christianity; they were precluded from any office or profession which gave them any authority over Christians, and even from ordinary social intercourse with them. They were ordered to occupy a separate quarter in every town or village, nor was more than a single synagogue to be allowed them in any place. The declining authority of this false-Pope, and his deposition soon after, prevented these "great swelling words" from being carried into effect.

But all the efforts of all the enemies of the Jews combined, were feeble when compared with that fearful engine of Papal persecution, the Inquisition. In Catalonia and Aragon, the Holy Office (as this abominable court was monstrously named) had long 
been established, but had not yet taken permanent root in Castile and Leon, or in Portugal. But on the union of the kingdoms of Castile and Aragon under Ferdinand and Isabella, it was permanently introducced in a more appalling form, and became more absolute, tyrannical, and independent than in any other country. [147\%.]

The large number of converts from Judaism, which from various causes had been made in the Peninsula, since the waning of the Moorish supremacy, were the objects which the Inquisitors had mainly in view. Their power had at first been assumed in order to crush and exterminate the Albigenses, a people who in the South of France, and among the fastnesses of the Pyrenees, had preserved their faith and practice in primitive purity, and had unscrupulously testified against the corruptions of the Church of Rome. At length their voice was silenced, for they had all fallen beneath the sword of merciless warfare, or the flames of the more cruel Inquisition; their country was devastated, and the "Holy" Office had sunk into comparative desuetude, for the lack of heretics on whom to wreak its vengeance. But the multitude of Jews whom fear or interest had induced to make an insincere profession of Christianity, and the readiness with which they relapsed into Judaism, whenever opportunity allowed, rekindled its fires more fiercely than ever. Hodija, the prior of the Dominican convent of Seville, and Barberis, inquisitor of Sicily, which was then subject to Aragon, strongly urged upon the Spanish king and queen, the neces- 
sity of a sterner vigilance over the "new Christians," as these converts were called, and of punishing those who relapsed.

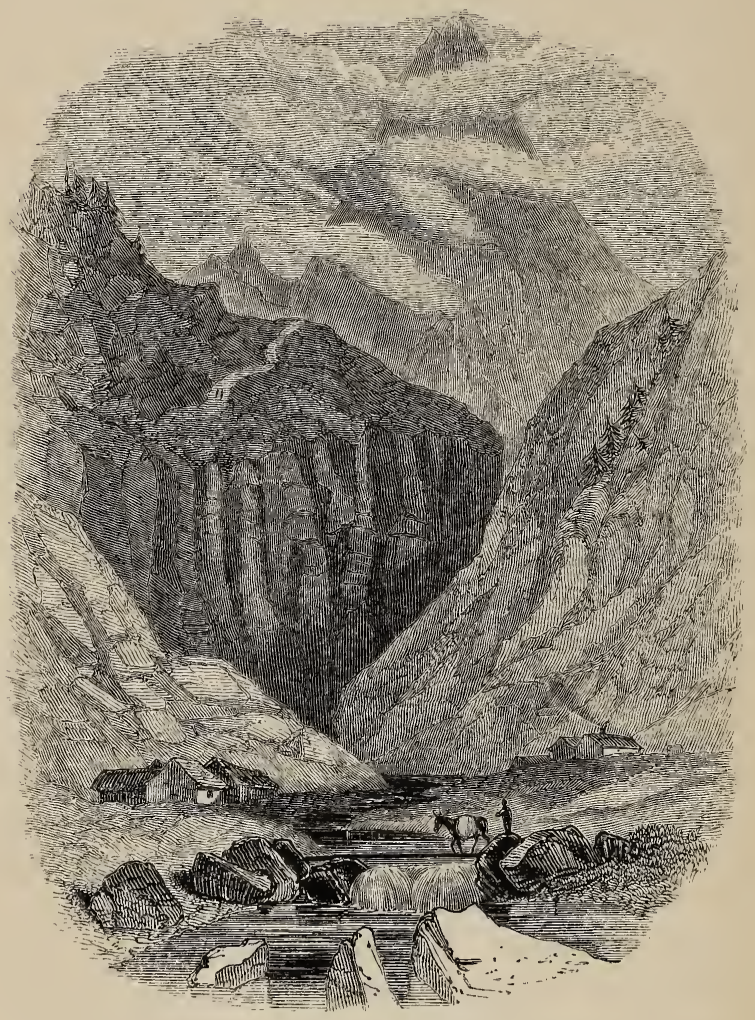

THE PYRENEES.

"The converts or children of converts from Judaism, were looked upon with dislike and mistrust by the old Christians, and many of them were 
at the same time among the wealthiest merchants and monied men of Spain, and as such had numerous debtors. Reports were spread of their secret meetings with those who had remained Jews, of their profaning the images of Jesus, and even crucifying Christian children. Ferdinand easily listened to the suggestion; but Isabella, a princess of mild character, hesitated for some time, and without her consent nothing could be effected in the dominions of the crown of Castile. Means were at last found to alarm her conscience; she was told that the interests of religion required her acquiescence, and accordingly she solicited by means of her ambassador at Rome a Papal bull, authorizing the establishment of the Inquisition in the kingdom of Castile. The bull, dispatched from Rome in November, 1478, authorized Ferdinand and Isabella to appoint two or three bishops or other dignitaries of the church, aged at least forty years, of irreproachable character, graduates in theology and the canon law, who were to be commissioned to seek after and discover, throughout the dominions of the Spanish sovereigns, all apostates, heretics, and their abettors, with full power to proceed against them according to law and custom. Isabella however suspended the execution of the bull for two years, desiring at the same time that measures of persuasion should be adopted to warn the relapsed converts of their error and of their danger. A catechism was composed expressly for them, and several pamphlets against Judaism were issued. In 1480 the Cortes of Castile assembled at Toledo, 
and passed several restrictive measures against the Jews, with the view of checking their intercourse with the Christians. Nothing however was said in that assembly about the Inquisition. At last, in September, 1480, Ferdinand and Isabella, who were then staying at Medina del Campo, appointed two Dominicans as inquisitors, with an assessor and a fiscal attorney; and on the 9th of October, a royal order was despatched to the governors of provinces to furnish the new inquisitors and their retinue with everything necessary for their journey to Seville; and at the same time their privileges were declared, which were the same as those granted by the Emperor, Frederic II., to the inquisitors in Italy in the thirteenth century. The inquisitors established their court in the Dominican convent of St. Paul of Seville; whence on the 2nd of January, 1481, they issued their first edict, by which they ordered the arrest of several New Christians as they were styled, who were strongly suspected of heresy, and the sequestration of their property, denouncing the pain of excommunication against those who favoured or abetted them. The number of prisoners soon became so great, that the Dominican convent not being large enough to contain them, the court was removed to the castle of Triana, in a suburb of Seville. The inquisitors jssued another edict, by which they ordered every person, under pain of mortal sin and excommunication, to inform against those who had relapsed into the Jewish faith or rites, or who gave reason for suspecting them of being relapsed, specifying numerous indi- 
cations by which they might be known. Sentences of death soon followed; and in the course of that year 1481, 298 new Christians were burned alive in the city of Seville, 2,000 in other parts of Andalusia, and 17,000 were subjected to various penalties. The property of those who were executed, which was considerable, was confiscated." *

The slightest proof of lingering attachment to the customs of his fathers was sufficient to condemn the accused before this inexorable tribunal; as if it were essential that conversion should eradicate at once all former habits, however inveterate, and all predilections, even for things indifferent. "It was considered good evidence of Judaism," observes Mr. Prescott, "if the prisoner wore better clothes or cleaner linen on the Jewish sabbath, than on other days of the week; if he had a fire in his house the preceding evening; if he sat at table with Jews, or ate the meat of animals slaughtered by their hands, or drank a certain beverage held in much estimation by them; if he washed a corpse in warm water, or, when dying, turned his face to the wall; or finally, if he gave Hebrew names to his children,-a provision most whimsically cruel, since, by a law of Henry II., he was prohibited, under severe penalties, from giving them Christian names." $\downarrow$

The jurisdiction of the Inquisition extended only

* Mariana, Hist. de España. b. 24, ch. xvii. quoted in Penny Cyclop. Art. Office (Holy).

† Hist. of Ferd. and Isab. i. 367. 
to those who professed, or had professed the Christian faith : multitudes of these suffered confiscation of their property, or pined in loathsome cells, or were agonized by dreadful tortures, or perished by a horrible death. But the Jews, who, resisting the temptations of fear and of avarice, had remained sternly true to the faith of their ancestors, were as yet untouched by the Inquisition. Their immunity, however, was of short duration. The last two centuries had each marked its close by the expulsion of the Jewish people from a country which had afforded them a shelter, and the fifteenth was about to terminate with a similar catastrophe, still more terrible in its extent, and in its attendant misery. The Inquisitors did that by art which they could not do by force; by incessant endeavours, alternately beseeching, exhorting, commanding, threatening, they at length prevailed on Ferdinand and Isabella to decree the edict for the final banishment of their Jewish subjects. It was in the year 1492, a year that added a new world to the dominion of Spain, that this iniquitous and ungrateful measure was adopted. The command was peremptory: every Jew was required to submit to baptism, or to depart, on pain of death. No crime was proved, nor even charged against the nation, which could warrant so extreme an act, save the old vague rumours of poisoning wells, and crucifying children. Four months were allowed them to prepare for their exile; their moveable property they were permitted to sell for bills of exchange, or to barter for merchandise, but their gold and 
jewels were not to be exported. Abarbanel, one of the most eminent names in Jewish literature, a learned commentator, and an able financier, who had enjoyed the favour of his sovereigns for many years, could not prevail to mitigate the rigour of the decree, nor to secure his own immunity. He fell at the feet of the monarchs whom he had so faithfully served, and begged with tears for the reversal of the edict; offering to recruit the exchequer, exhausted by the Moorish war, with the sum of 30,000 ducats. But Torquemada, the Inquisitor-general, stalked into the royal presence, bearing a crucifix in his hand, which he held up before the king and queen. "Behold Him," cried the stern Dominican, "whom Judas sold for thirty pieces of silver, - and then follow his example!" To counteract the glittering temptation of the offered bribe, the archbishop of Toledo himself advanced the proffered sum, out of the treasury of the church.

The pitiless Inquisitor denounced the time allowed for preparation, as if every moment that the alien race remained were a curse, and demanded that it should be shortened. He fulminated severe penalties against any who should supply them with provisions, grant them shelter, or lend them any assistance.

Many individuals found their faith and courage too feeble to bear up against the temptation to apostatize, and preferred the dangers of an insincere profession to the horrors of exile. Yet the great majority remained faithful to their convic- 
tions, and exhibited a constancy which cannot but command our esteem, though it be mingled with pity. The number of the exiles was very great; Mariana, the Spanish historian, computes it at 800,000 ; but the Jewish writers reckon 120,000 families, or 600,000 souls. The extrusion of so immense a body of peaceable, industrious, and loyal subjects, could not but prove a serious detriment to the prosperity of the kingdom, impoverishing the national resources, drying up many fountains of wealth, diminishing the customs and taxes, and depriving the country of a large amount of talent, learning, and skill. It may have been some solace to the wounded pride and embittered feelings of the exiled nation, to watch how surely Spanish greatness has declined from that day; a decline which not even the acquisition of a new world availed to stay, so that from being the most renowned, the most opulent, and the most mighty of the nations of Europe, she has become one of the meanest, and poorest, and most despicable.

Dreadful were the sufferings that attended this wholesale exile. "No one," observes a Jewish historian, "can describe, or even imagine all the calamities that befel the Hebrews on their departure from Castile; such as the horrible famine which some experienced on their voyage; the ferocity of the robbers, who upon land despoiled others of all they possessed; the barbarity of the masters of vessels, who carried others away into distant lands, and sold them there as slaves, pretending 
that they were prisoners of war, or threw the sick and infirm into the sea, in order to seize upon their effects.

Some of these horrors are thus enumerated by Basnage.* "The fire seized some transport vessels, and consumed all the passengers; many were shipwrecked, and perished in the sea, either through the fault or the design of the pilots. The pestilence having infected the rest, the pilots sent them on shore. Part of those that landed, being cured, died of hunger. Others arrived at $\mathrm{Fe}^{2}$, where the inhabitants, frightened at such multitudes of fugitives, shut up the gates. They were forced to set up tents in the field, to live upon some herbs which the drought and barrenness rendered very scarce. Besides the injuries of the air they were forced to submit to the insolence of some inhabitants, who thought all things were permitted them against the miserable. . . . A sailor surprised a company of children who came to look for shell-fish and other fish when the sea retired. He made them come on board his bark, where he gave them bread, which attracted a great number of them. One day he weighed anchor, and carried off all the young children, which he sold to some great lords, and made slaves of the rest. A Spanish pilot entered upon a resolution of murdering all the passengers, to revenge, as he said, by their death, the blood of Jesus Christ which they had shed. But he was told that Jesus Christ, who had shed his blood for man's redemption, did not require a sinner's

* Hist. of Jews, lib. vii. cap. 21. 
death. Softened by this remonstrance, he contented himself with stripping them and throwing them upon the shore, where they had fresh miseries to contend with. Part of them died after they had suffered hunger for three days. Some were torn by lions that came out of a neighbouring cave. Others were saved by the charity of a pilot, who seeing them in so dismal a condition, received them into his vessel, and tore his sails to cover their nakedness. Those that made their way to Italy arrived at Genoa, where the famine rendered provisions extremely dear. The inhabitants seeing these fugitives attenuated by so long sufferings and destitute of money to buy food, went into the streets, holding bread in one hand and a cross in the other; offering the bread to these famished creatures, upon condition of worshipping the cross. This stratagem succeeded, and such as had had courage to leave their estates and country, submitted to this second temptation."

The proximity of Portugal to Spain afforded facilities for the poor refugees, of which they were willing to avail themselves. The Jews in that kingdom had never enjoyed the consideration of their brethren in Spain; yet their condition had been, on the whole, tolerable. They were allowed the jurisdiction of their own tribunals in all civil cases, which were under the presidency of the chief Rabbi. His decisions were subject only to the authority of the king. Many of the Portuguese Jews have been distinguished in science and literature, and especially for the beauty and 
correctness of their manuscripts of the Sacred Scriptures.

John II., at this time King of Portugal, was not insensible to the advantage of receiving the subjects that were in so impolitic a manner thrust out of the neighbour kingdom. But his avarice prompted him to take advantage of their necessities, and to impose a heavy tax upon the privilege which he conceded. Every Jew on entering the kingdom was compelled to pay eight golden crowns, which were collected by officers stationed at all points of the frontier. But this concession did not grant a naturalization, but merely the privilege of residing for a defined time in his dominions, after which, if any chose to remain, it was only on the condition of becoming slaves. A great number of the fugitives embraced the latter alternative, as the more tolerable misfortune.

Emanuel, the successor of John, began his reign by an act of clemency, delivering these wretched bondmen from the chains of slavery. But having formed a matrimonial alliance with the Spanish sovereigns, he imitated their cruel policy. In 1496, he too published a decree of banishment for the miserable fugitives. To add to their sufferings, he forbade them to carry away their children under fourteen years of age, whom he forcibly detained, in order to baptize them. Such was the manner in which the religion of the Lord Jesus Christ was then promulgated!

This dreadful decree, surpassing in barbarity anything that had hitherto befallen them, filled the 
nation with despair. It was a heavier stroke than the crowning plague upon Egypt; there every house had mourned its first-born; here every family was deprived of all its little ones, not to be hid in the grave,- ihat might have been borne !-but to be forcibly proselyted to a religion, which they deemed, and not without reason, to be idolatry. These were the tender mercies of Papal Rome, in which cruelty has always kept pace with her other crimes, whenever she has had the power to exercise it.

It moves our pity, but not our wonder, to learn that under the powers of the strong despair, mothers imbrued their hands in the blood of their infants, or threw them into the rivers; and many more laid violent hands upon themselves. In others parental yearnings were more powerful than conscience, and many consented to be themselves baptized on condition that they might still preserve their children.

Converts so made could not hope to escape the keen eye of inquisitorial persecution. They were always suspected; and the first occasion that presented itself brought down on their unhappy heads a worse fate than that which they had dissembled to avoid. There was in the cathedral at Lisbon an image of the Lord Jesus crucified, the wound of which was covered with a glass. Some imaginative devotees declared that they saw a divine light stream through the glass, and began to cry out, " a miracle!" A Jewish convert venturing to deny the fact, was instantly murdered. The Dominicans took advantage of the excited state of the populace, 
and exhorted them to sacrifice the whole race, promising deliverance from purgatory to every man who killed a Jew. The tumult lasted for three days, during which Lisbon streamed with the blood of her unoffending citizens : more than two thousand "new Christians" were slain, many of them even in the churches, and on the steps of the altars, whither they had vainly fled for sanctuary. On the return of the king, who had been absent from the capital at the time, an inquiry was instituted into the disgraceful riot; the monks who had stirred up the mob were put to death, and the supine, or perhaps secretly approving, magistrates were degraded.

We have seen four of the principal kingdoms of Europe, one after the other, concurring in the cruel and unwise policy of driving the Jews from them. At their condition in other countries during the middle ages, we can but briefly glance. In Italy it was, upon the whole, less severe than the average. Some of the popes, indeed, were sufficiently intolerant, as John XXIII. in the beginning, and Eugenius IV. in the middle, of the fifteenth century; whose edicts are distinguished by the most persecuting severity. On the other hand, there have not been wanting popes who have extended the powerful shadow of their protection to this wretched nation, when smarting under the cruelty of neighbouring states. Thus, though John XXII. had, by his accusations of sorcery, given a sanction to the atrocities of the shepherds on their first insurrection, the poor Jews on the repetition 
of that terrible calamity were received with sympathy and protection by Clement VI., in the papal territory of Avignon.

In Germany, where the Jews have always been numerous, they experienced the bitterness of popular hatred more than in any other country. The accusations ordinarily brought against them were here repeated with more frequency and virulence; and others were added, such as that they invited the Persians, and afterwards the Tartars, to invade Western Europe, offering to assist them with supplies of money, provisions, and arms. Acts of outrage, violent and sanguinary tumults, and general massacres, were also more numerous in Germany than elsewhere, as well as more bloody.

In the year 1288, a dreadful massacre of this devoted people began at Munich, almost contemporaneous with one equally furious at Prague. The charge of sacrificing a child was again the fruitful occasion of the bloodshed. The example spread through the neighbouring countries, until all Bavaria, Bohemia, and Moravia flowed with torrents of Jewish blood. Multitudes were dragged into the streets and slain: others were burned in the dwellings to which they had fled for refuge; and other outrages too dreadful to be described were perpetrated by the infuriated populace, under the pretence of avenging the honour of Christ. Ten thousand Hebrews are computed to have perished in this persecution, which was one of the most dreadful that have ever befallen the nation in the dispersion. 
A few years after, a fanatic peasant named Flaisch travelled through the cities of Franconia and $\mathrm{Ba}$ varia, preaching every where that God had sent him to destroy the Jews. A great number were consequently put to death by the bloodthirsty mob, ever ready to renew such acts of violence. The contentions of Albert of Austria and the Count Adolph of Nassau, for the empire, rendered each of them afraid of repressing these outrages, lest he should diminish his own popularity, and increase the party of his rival. The cities of Nuremberg, Nieumark, and Amberg enjoyed an odious eminence in this atrocity.

Through the whole of the fourteenth century similar excesses prevailed, which we have not space to enumerate. Most of them were grounded on the accusation, perpetually brought with trifling variations of circumstances, that the Jews stole the consecrated host, or the bread used in the eucharist, in order to pierce it with knives. The wafer in every instance was reported to have proved its supernatural vitality, by streaming with blood wherever wounded; a report which never failed to excite the popular fanaticism to the highest pitch. Sometimes it was a crucifix, or an image of the Virgin, which miraculously poured forth its blood under the Jewish knives. It is curious to observe how intimately the persecutions of the miserable Children of Israel were connected with the idolatries and lying wonders of Popery.

But we cannot pass without mentioning the cala- 
mities that marked the middle of the fourteenth century. A dreadful and mysterious pestilence commonly known as the Black Death, ravaged the central portion of Europe, and carried off an immense number of people. In the midst of this visitation, appeared a sect of fanatics called Flagellants, who, assembling twice a day in the streets and public places, flogged their own naked bodies with whips, the lashes of which were armed with points of iron. They proclaimed aloud that these sufferings were borne by the command of God, to atone for the sins that had called down his vengeance, and to deliver the souls that were groaning in purgatory. Their denunciations, however, were principally fulminated against the Jews, whose tolerated presence they avowed to be the chief cause of the anger of God. Others accused the same unhappy race of being the actual agents in the production of the fatal plague, either by their magical incantations, or by poisoning the rivers and wells.

These accusations were attended with the usual fatal results. The inflammable mob were easily aroused to vengeance. At Frankfort, amidst the tumult, a Jew threw a firebrand into the Townhouse, which was burned down, as well as the church and a portion of the town. This act aggravated the violence of the opposite party, and all the Jews in the city were put to death except a few that escaped into Bohemia. All the Hebrew inhabitants of Ulm were burned with their families and their effects. In Austria the reigning duke endeavoured to pro- 
tect them, but popular feeling ran so high, that he was not only unable to save them, but was compelled to give the sanction of his own authority to the burning of three hundred at Kyburg. At Strasburg, still more terrible were the results. Here the municipal authorities, having endeavoured to check the fury of the mob, were instantly deposed, and others chosen in their room, who were less scrupulous. The newly elected magistrates caused several of the principal Jews to be examined by torture, under the agony of which they confessed anything that their accusers demanded; on which, without further evidence, they were immediately broken alive on the wheel. All the rest of the Jewish inhabitants were cast into prison; but the mob, impatient of legal forms, however distorted, forced open the prison-doors, and having dragged their victims, to the number of several hundreds, to one of the public squares, there put them to death.*

At Mentz, the slaughter was even more immense. The Jews in this populous city, had stood on the defensive, and banding together, had gained a temporary advantage. They had succeeded in surprising two hundred of their persecutors, whom they put to death without mercy. But this cruelty only the more whetted the popular desire of revenge. The whole population of the city rose in arms, and fell upon the Jews with such fury, that it is said twelve thousand perished in that city alone $; \dot{\psi}$

* Depping, Les Juifs dans le Moyen Age, p. 263, et seq. + Basnage. 
though we cannot help suspecting some exaggeration.

We have traced the fortunes of the seed of Abraham from the overthrow of their City and Temple, the destruction of their national polity, and their dispersion among the Gentiles, down to the beginning of the fifteenth century. Darkly had the cloud of divine wrath hung over them through these long ages, sometimes lightening a little, it is true, but again lowering in deeper obscurity and gloom. At the period to which our history has now come, the national tribulation may be considered as having reached its highest point; still shut out from the land of his fathers, proscribed, banished, persecuted in almost all lands, the Jew wandered over the earth a fugitive and a vagabond, vainly seeking a rest for his bleeding feet.

Many of the bitter sufferings that befel this ancient people, once the "chosen of God," we have exhibited in detail ; much more of a similar character remains untold; but we gladly refrain from further unfolding scenes of cruelty that make the heart sick. But the reflecting mind, musing on these sorrowful records, asks with wonder for an explanation of them. The pages of human history have always been blotted with blood; and details of injustice, oppression, and lawlessness, have distorted the annals of all nations: - but why has the unhappy exile of a thousand years, the homeless Jew, been so preeminently the object of hatred and persecution? As respects the ordinance of God, we answer, that this was an ingredient in the cup of bitterness, which Israel 
was doomed to drink to the dregs, for their inestimable crime in rejecting the Lord Jesus Christ. He had predicted that the sinful nation should know a long night of weeping, of "lamentation, and mourning and woe;" a "time of trouble, such as never was since there was a nation, even to that same time;" days of vengeance, in which all things written should be fulfilled. The God of Israel had so decreed, and $\mathrm{He}$ accomplished His word; and we may form some notion of the enormity of the national sin, by the heaviness with which His hand fell in wrath upon His people.

But if we look at these woful transactions in another aspect, considering them only as regards man, what shall we say? The poor Jews were generally peaceable, unoffending, intent upon securing the profits of lucrative, though sordid, industry, happy if they could shroud their heads from the blast which had swept them from their own land. After the first few centuries had cooled down the fiery impatience with which they had at first spurned the yoke of exile they constantly proved themselves quiet citizens and loyal subjects, seeking the prosperity of the land in which they sojourned. What then was the principle which was sufficiently potent to overcome the dictates of humanity, of brotherhood, of hospitality, of sympathy, of compassion, of justice, of mercy? and to pursue the weary, heart-broken wanderer with a hatred, the rancour of which neither his losses, nor his sufferings, nor the shedding of his blood, nor the lapse of centuries, could assuage? It was Reuigious 
BIGOTRY. Mistaking altogether the character of true religion, which is pure and peaceable and gentle, like its Holy Author, men strangely believed they were doing God service, while they were indulging the vilest and fiercest passions of our nature, and manifesting the diabolical spirit of him who was a murderer from the beginning. It was in the name of Christ that these dark deeds were perpetrated; that avarice, and lust, and revenge, and hatred, and cruelty, did their horrid work, - as if that Blesssed and Holy One could have any sympathy with such deeds as these! No: they were of their father the Devil; and the lusts of their father they did; and the religion which sanctioned such crimes, though it took the name and guise of Christianity, was not from above, but from beneath.

But a new era was now dawning upon the world: the darkness of the middle ages was about to pass away, and the true light, the light of the blessed Word of God, long concealed, was breaking, once more, upon the world. A mighty blow was about to be struck at the spiritual tyranny of Rome, which had for so many years held in bondage the minds of men. Into the era now commencing, however, it is not the design of this volume to enter. We will content ourselves with saying, that the Jew felt the benign influence of the times, in the amelioration of his forlorn condition, and gradually gained that position of toleration which he still retains in most of the civilized nations of the world. 
The history of the chosen people is calculated to teach us some important lessons. Prominent on its pages, written in characters so plain that he who runs may read, is the solemn truth that "man at his best estate is altogether vanity." The utter inability of fallen man to stand before God in righteousness, is here depicted in lively colours; since if ever any people could have maintained a position of integrity it must have been the seed of Abraham ; separated as they were to God in power and mercy, and furnished with the Law from His own mouth: "to them were committed the oracles of God." Yet we have seen that so far from being better than neighbouring nations, "the name of God was blasphemed through them among the Gentiles ;" and notwithstanding long-suffering, warning, and intreaty, they sank lower and lower in guilt, till at length Jehovah was compelled to interpose in wrath "for His Holy Name's sake, that it should not be polluted among the heathen."

The fall and dispersion of Israel show us the " exceeding sinfulness of sin."* "The way of transgressors is hard," All the dealings of God with the nation had been' marked by the fullest grace and love : this His Word repeatedly declares; over and over is the backsliding nation reminded of the unmericed favour with which Jehovah had re-

* Rom. vii. 13. 
garded them and their fathers, and many and tender are the yearnings with which even in the days of their deep transgression He still looked upon them. God had truly loved Israel; and yet such a tribulation, so intense, and of so long continuance, has never fallen upon a people since the foundation of the world. How are these facts consistent with each other? Is God changeable? Far be it from Him; $\mathrm{He}$ is "the same yesterday, and to-day, and for ever;" in Him there is " no variableness nor shadow of turning;" yea, the very preservation of the seed of Jacob is declared to be because $\mathrm{He}$ changeth not. How abominable then must sin be in the pure and holy eyes of Jehovah, when it has brought down so severe a visitation upon the people whom $\mathrm{He}$ had chosen, whom He had separated to Himself, whom $\mathrm{He}$ had distinguished with so wondrous tokens of his regard, and whom $\mathrm{He}$ declares that $\mathrm{He}$ had loved "with an everlasting love!"

But the history of the people of Israel is pregnant with solemn warning to us. The Holy Spirit himself uses it for our admonition. "Be not highminded, but fear : for if God spared not the natural branches, take heed lest he also spare not thee!" The Jewish church was in "severity" broken off from the manifested favour of God, that the Gentile church might be in "goodness" graffed in. Dare we say that we have "continued in his goodness?" that we have walked in faithfulness to the grace of God, so as to magnify before the world that blessed Name by which we are called? O 
surely there is much need of that humbleness and fear, that the inspired Apostle recommends, lest judgment should begin at the house of God.

O THE DEPTH OF THE RICHES BOTH OF THE WISDOM AND KNOWLEDGE OF GOD! HOW UNSEARCHABLE ARE HIS JUDGMENTS, AND HIS WAYS PAST FINDING OUT! For WHO HATH KNOWN THE MIND OF THE LORD? OR WHO HATH BEEN HIS COUNSELLOR? OR WHO HATH FIRST GIVEN TO HIM, AND IT SHALL BE RECOMPENSED UNTO HIM AGAIN? For of HIM, AND THROUGH HIM, AND TO HIM, ARE ALL THINGS: TO WHOM BE GLORY FOR EVER。 Amen.

FINIS. 



\section{N D E X.}

Academies, Jewish, 265, 324.

Acra, 145, 197.

Adrian, tyranny of, 227. rebuilds Jerusalem, 229.

Agrippa, mediation of, 30, 46.

Akiba, history of, 231. fate of, 235.

Alexander Severus, character of, 244.

Ananus, 120 ; slain, 122.

Antonia described, 154 . taken by the citizens, 36 . taken by Titus, 185 .

Antoninus Pius, character of, 244. Ascalon, Jews defeated at, 61 .

Babylon, Jews at, 264. [36]. Banishment of Jews from England, from France, 364, 368. from Spain, 378. from Portugal, 383.

Bar-Cocheba, rise of, 231. crowned king, 234. besieged, 234 . slain, 234 .

Battering ram, 72, 166.

Bezetha, 145, 166.

Bither besieged, 234 . site of, 237.

Black Death, 388.

Cæsarea, outbreak at, 25. massacre of Jews at, 38.

Cestius marches for Jerusalem, 40. encamps at Gibeon, 41. retreats to Beth-horon, 45 . encamps at Scopus, 46. takes Bezetha, 47. besieges the Temple, 48 . disastrous retreat of, 52 .
Charlemagne favours the Jews, 329.

Child eaten by its mother, 181 .

Christians, flight of, 49 .

Christianity, corruption of, 314 .

Circumcision prohibited, 227, 309.

Councils, edicts of, 301,306 .

Crucifixions of captives, 174 .

Crusades, origin of, 333.

fatal to the Jews, 337, 340, 365.

Cyprus, insurrection in, 224.

Cyrene, outbreak at," 222.

Daily sacrifice, cessation of, 187 ,

Disputations, public, 371.

Domitian, jealousy of, 218.

Eleazar, 32, 56 .

character of, 32 .

Embankments, 69, 83, 175, 183, 197.

Extortion and pillage, 356, 358.

Factions in Jerusalem, 35, 137, 157.

Famine, horrors of, 172, 178, 181.

Florus, oppressions of, 25, 27.

France, Jewish prosperity in, 328.

Gadara sacked, 66.

Galilee fortified, 57 . attacked, 63.

subjugated, 110.

Sea of, $93,98,111$.

Gamala besieged, 102. taken, 107.

Gardens desolated, 158.

Gemara, 258.

Gibeon, 41. 
Gischala taken, 109.

Gregory the Great, moderation of, 296.

Hebrew language, neglect of, 287. Heraclius enters Jerusalem, 305.

Hippicus, the tower, 148.

Homerites, kingdom of the, 313.

Idumea subdued, 131.

Idumeans called in, 121. return home, 124 . negotiate with Titus, 197.

Inquisition, cruelties of, 363,372 .

Jericho, 132.

Jerusalem, desolation in, 126. besieged by Simon, 135 . attacked by Titus, 141 . description of, 142. walls of, 145 .

first wall taken, 166 . second wall taken, 169 . famine in, 172. wickedness of, 173 . encompassed by a wall, 178 . desolated, 198.

dug up to its foundations, 208. rebuilt by Adrian, 229. sacked by the Persians, 304. besieged by the Arabs, 320 . pilgrims in, 385 . sacked by the Crusaders, 340 .

Jesus, son of Shaphat, 97. son of Ananus, 205.

Jews, rage of, against Christians, $245,269,286$. blasphemies of, 245 . dispersions of, 246. at Babylon, 264. persecuted by Christians, 270, $283,301,306,337,363$. allied with the Magi and the Arians, 274.

prosperousunder the Goths, 291. oppressed by Justinian, 292 . prosecute the slave-trade, 299. banishments of, $361,364,368$, $378,383$.
Jews, in Persia, 302, 322.

in Arabia, 312.

in Spain, 323.

in France, 328, 341 .

in Germany, 337, 340, 386.

in England, 345 .

in Portugal, 383.

in Italy, 385 .

John of Gischala, 58, 119, 168, 198.

Joppa destroyed, 90 .

Jordan, slaughter at, 130.

Josephus, character of, 57 . defends Jotapata, 67. accompanies Vespasian, 87. appeals to the citizens, 172 .

Jotapata attacked by Placidus, 65 . besieged by Vespasian, 67 . a breach effected, 78 . captured, 84. sacked, 85.

Jude, grandsons of, 218. Julian, accession of, 275 . favours the Jews, 276. essays to restore the Temple, 277.

his failure, 281.

Justinian, character of, 292. oppresses the Jews, 292.

Magi, Jewish alliance with, 274 .

Masada, seizure of, 32 . fall of, 217.

Massacre of the Roman garrison, 38.

at Taricheæ, 100.

at Jerusalem, 123.

of captives, 180 .

at Alexandria, 223.

Menahem assumes the title of king, 37. death of, 38 .

Mesopotamia, insurrection in, 225.

Messiahs, false, 293.

Milan, Archbishop of, 284.

Military engines, $69,72,76,161$, 176 .

Mishna, 250.

Mohammed, rise of, 313 . conquests of, $315-319$. 
Mosque of Omar, 321.

Naples, siege of, 295.

Nero, death of, 134 .

Nerva, mildness of, 219.

Number of Jews destroyed, 202, $226,235$.

Ophel, 146.

Passover, feast of, 157.

Patriarch of Tiberias, 249, 288.

Perea subjugated, 128.

Peter the Hermit, 335.

Placidus repulsed from Jotapata, 65.

takes Mount Tabor, 105. reduces Perea, 128.

Priesthood, desecration of, 120.

Prince of the Captivity, 264, 266, 332.

Prodigies, 203.

Rabbins, eminent, 250, 324 .

Reformation, era of the, 392 .

Revolts of the Jews under Trajan, 221.

under Adrian, 231.

under Constantius, 275.

under Justinian, 294.

under the Persians, 302.

Richard I., tumults under, 349.

Roman pageant, 170.

Sanhedrim finds refuge in Tiberias, 248.

Shepherds, insurrections of, 365 .

Sicarii, 126.

Siege, mode of conducting, 160 .

Simon, son of Gioras, 135, 198. enters Jerusalem, 136.

surrenders, 210.

cruel fate of, 212.

Slanders against Jews, 347, 359, $363,367,368,388$.

Slave trade in the hands of Jews, 299.

Spain, Jewish prosperity in, 323, 369.
Stratagems of war, 69, 70, 71, 74, $80,81,175$.

Tabor, Mount, 105.

Talmud, formation of, 257 . character of, 258 . burned by the Pope, 364 .

Taricheæ, 92. besieged, 97 .

Tax on Jews, 217.

Temple, desecration of, 139, 196. described, 143, 149. attacked by Titus, 188 . the cloisters destroyed, 189. fired, 192. destroyed, 194. spoils of, 211, 305 .

Theodoric, equity of, 291.

Titus despatched to Alexandria, 62.

arrives at Ptolemais, 64 .

takes Gamala, 108.

takes Gischala, 109.

attacks Jerusalem, 139.

in danger, 141.

encamps at Scopus, 142.

takes the first wall, 166 .

takes the lower city, 170 .

calls a council of war, 177, 192 .

surrounds the city with a wall,

178.

attacks the Temple, 188.

plunders the Lower City, 197.

takes Zion, 198.

utterly destroys Jerusalem, 208.

cruelty of, 209.

triumphs at Rome, 211.

arch of, 212.

Towers, 147.

of besiegers, 164 .

Tradition, oral, 251.

Trajan favours the Jews, 220.

Tumults against the Jews at London, 350 .

at Norwich, 351.

at York, 351.

at Chinon, 367.

at Lisbon, 384 .

in Germany, 386. 
Turks, conquests of the, 334 .

Tyropæon, 145, 1.97.

Usury, 341, 344, 360.

Valour of Jews, 75, 155, 168, $176,186$.

Vespasian takes command, 61. attacks Galilee, 63.

wounded, 76 .

repulsed, 82.

removes to Cæsarea, 87.

visits Agrippa, 90.

in danger at Gamala, 105.
Vespasian subdues Idumea, 131. raised to the throne, 136 .

Wall of circumvallation, 178 .

William the Conqueror, 347.

William Rufus, 347.

York, siege of, 353.

Zacharias, son of Baruch, 123. Zealots, 120, 125, 137.

Zion, 146, 196. taken, 198.

church on, 218.

\section{LONDON :}

Printed by SaMuel Bentley \& Co.,

Bangor House, Shoe Lane. 




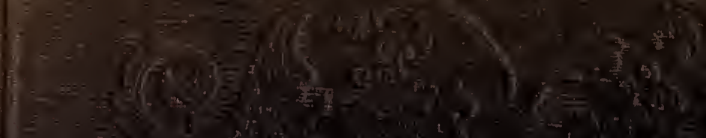

3

$7+(+4)$

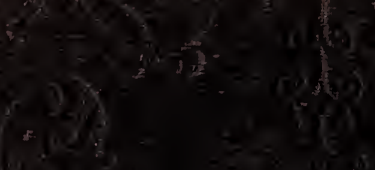

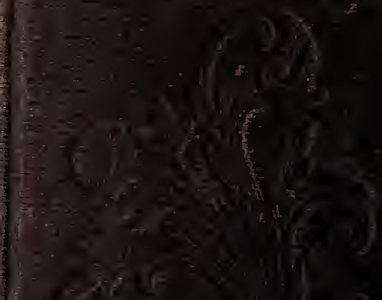

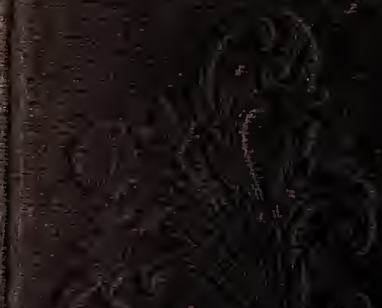
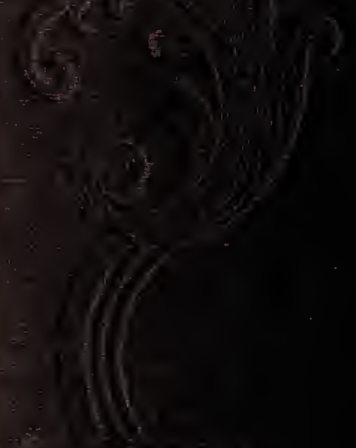

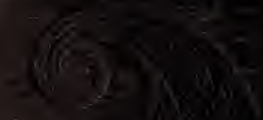
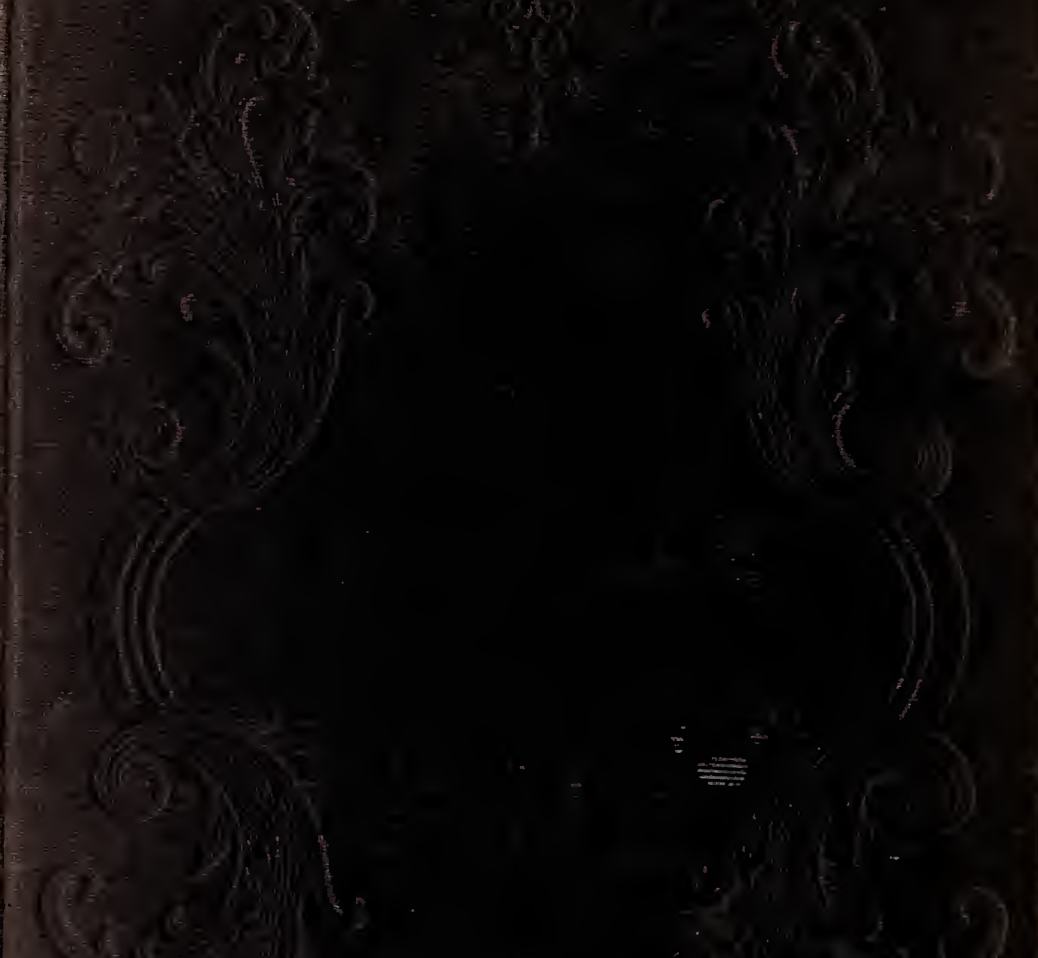

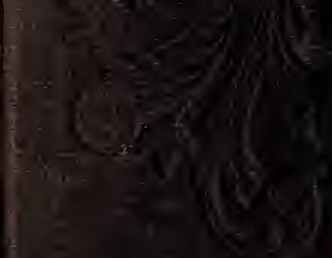
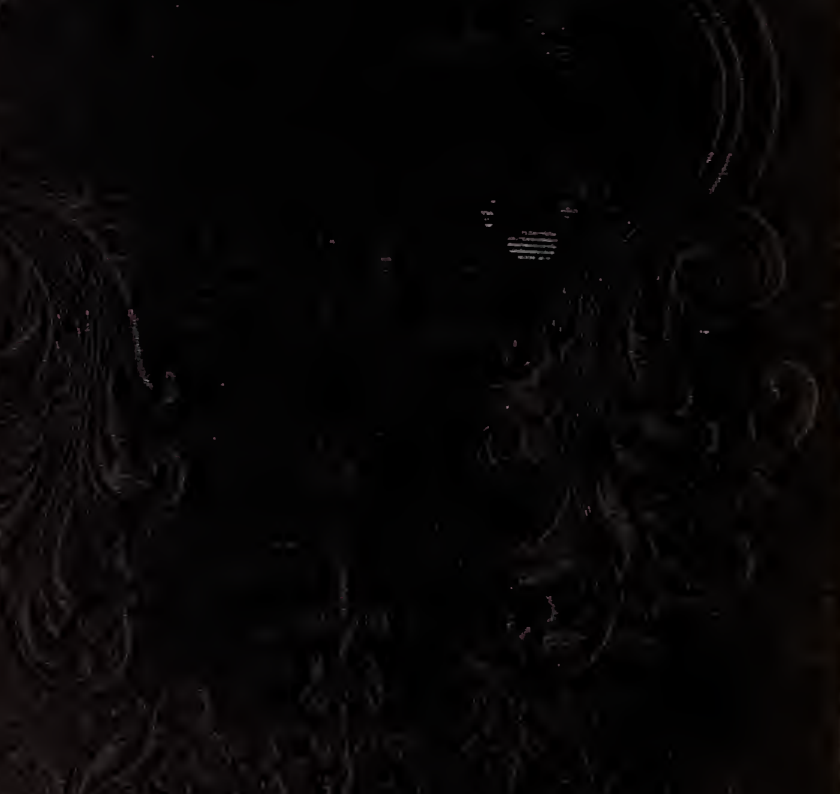

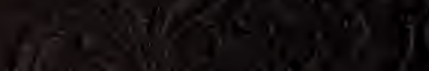
oh 